Gabriela Kazue Ferreira Eberhardt Francisco

Recorribilidade excepcional das decisões interlocutórias e efetividade da tutela jurisdicional

\author{
Dissertação de mestrado \\ Orientador: Professor Doutor Oreste \\ Nestor de Souza Laspro.
}

UNIVERSIDADE DE SÃo PAULO

FACUldade de Direito do LaRgo de SÃo Francisco

São Paulo - 2013 
Gabriela KaZue Ferreira Eberhardt Francisco

\section{Recorribilidade excepcional das decisões interlocutórias e efetividade da tutela jurisdicional}

Trabalho apresentado à Faculdade de Direito da Universidade de São Paulo, área de Direito Processual, para a obtenção do título de mestre.

Orientador: Professor Doutor Oreste Nestor de Souza Laspro.

Universidade de São PaUlo FACUldade de Direito do LaRgo de São Francisco São Paulo - 2013 


\section{BANCA EXAMINADORA}

Orientador: Prof. Dr. Oreste Nestor de Souza Laspro 


\title{
RESUMO
}

O presente trabalho se propõe a buscar identificar se existe relação entre a recorribilidade das decisões interlocutórias e a efetividade da tutela jurisdicional, de modo a compreender se as alterações legislativas a que vem sendo submetido o regime de agravo serão eficazes para resolver o problema da excessiva duração do processo. Para tanto, analisa-se o papel dos recursos no sistema processual, a necessidade do recurso de agravo, a relação entre o agravo e a preclusão de questões, o princípio da oralidade (que tem como subprincípio a irrecorribilidade em separado das decisões interlocutórias), e conceitos básicos sobre a efetividade. Ao final, procura-se responder ao questionamento a partir da análise comparativa das disciplinas do agravo a partir do Código de Processo Civil de 1939.

\section{Palavras-Chave}

Agravo - recorribilidade das decisões interlocutórias - reformas processuais - preclusão oralidade - efetividade.

\begin{abstract}
The present work aims to identify if there is a connection between interlocutory orders' appealability and judicial effectiveness, in order to understand whether legislative modification to which the discipline of the appeal (agravo) has undergone will be able to solve the problem of the process's excessive duration. To that purpose, the role of the appeal against interlocutory orders (agravo) will be analysed, as well as its necessity and the connection between such remedy and issue preclusion, the orality principle (and its sub principle, the unnapeallability of interlocutory orders), and basic concepts about effectiveness. At the end, it the primary question is answered by also comparing the discipline of the appeal against interlocutory orders since the Code of Civil Procedure, 1939.
\end{abstract}

\section{KEY WORDS}

Interlocutory orders - appealability - procedure modification - issue preclusion - orality - effectiveness. 


\section{Dedicatória}

Mãe, irmão, pai, avos, tios, primos, afilhada, sogros, cunhados e sobrinho. Dedico a todos porque o valor da nossa família é maior do que nossos valores individuais somados. Aos meus amados amigos da escola, da faculdade, de escritório e do mestrado, cada vez menos em número, mas cada vez mais em importância. E ao João - a quem já entreguei minha vida toda-, peço o favor de aceitar também essa dissertação. 


\section{Agradecimentos}

Ao professor Oreste Laspro, pela oportunidade de - com muito orgulho - me incluir entre seus alunos; e também pelas incríveis companheiras de jornada que sua orientação me proporcionou. Ao professor Carlos Salles, que me acompanha em todos os passos acadêmicos que dei desde o inicio da graduação e é provavelmente meu mais antigo amigo no Departamento de Direito Processual. Ao professor José Rogerio Cruz e Tucci, pelas valiosas e gentis observações na banca de qualificação. Ao Professor Flávio Yarshell, e a toda a equipe, por me ensinarem direito todos os dias. 


\section{ÍNDICE}

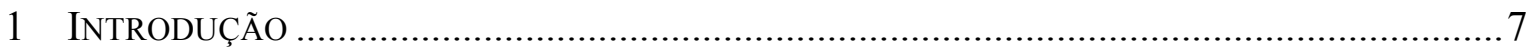

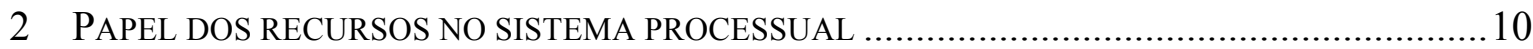

2.1 Recursos como mecanismos de revisão dos pronunciamentos judiciais.............................. 10

2.2 Segue: necessidade do recurso de agravo no sistema processual....................................... 17

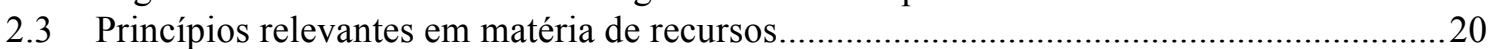

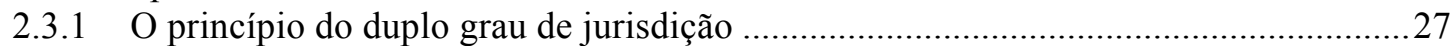

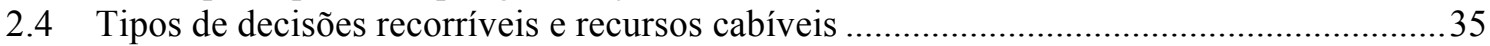

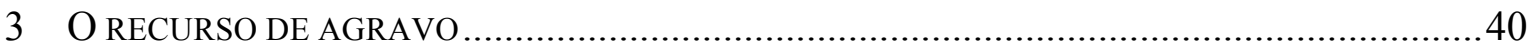

3.1 Agravo como recurso para a impugnação de decisões interlocutórias por excelência .......40

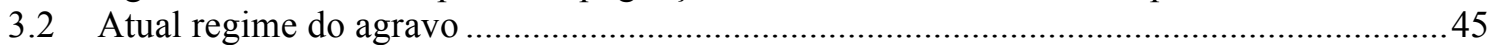

3.3 Da fórmula distintiva genérica "lesão grave e de difícil reparação" e sua implicação ....... 48

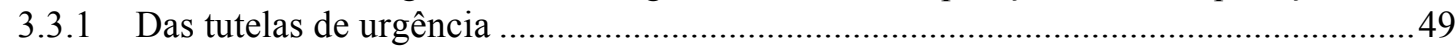

3.3.2 Das intervenções de terceiros: o exemplo da assistência.............................................57

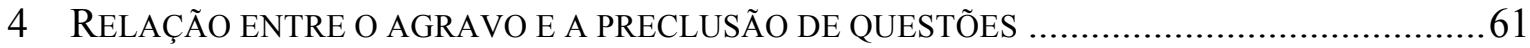

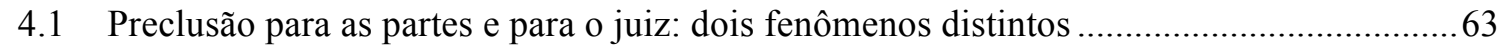

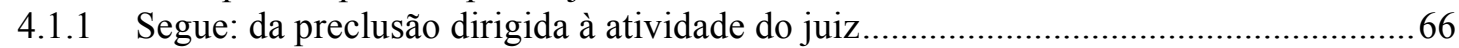

4.2 Contornos da preclusão dirigida à atividade do juiz no direito brasileiro ..............................70

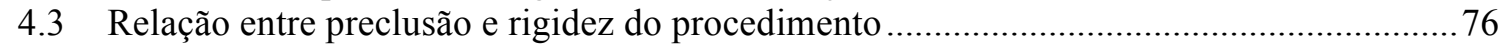

4.4 Relação entre a preclusão de questões e a impugnação de decisões interlocutórias ............. 81

4.5 Breve notícia sobre a preclusão de questões no direito processual civil italiano ...................85

\section{RELAÇÃO ENTRE A ORALIDADE E A RECORRIBILIDADE DAS}

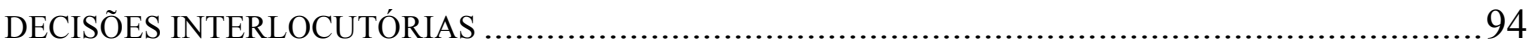

5.1 Procedimento oral idealizado por Chiovenda e o valor atual da sua construção teórica ....96

5.1.1 Princípios fundamentais do processo oral segundo Giuseppe Chiovenda................... 101

5.1.2 Irrecorribilidade em separado das decisões interlocutórias como corolário do

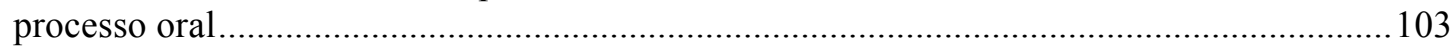

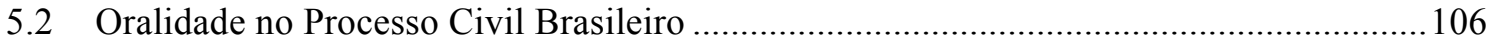

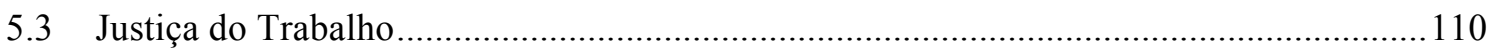

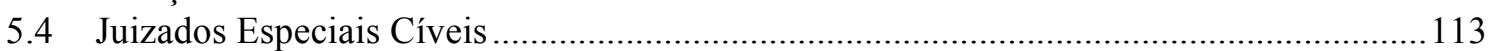

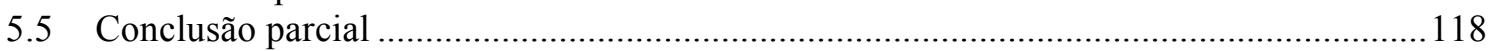

6 PREOCUPAÇÃO COM A EFETIVA ENTREGA DA TUTELA JURISDICIONAL EM TEMPO

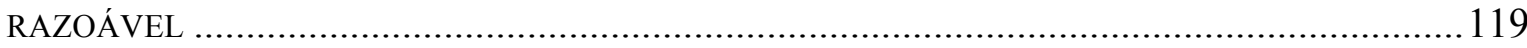

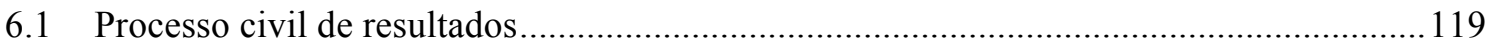

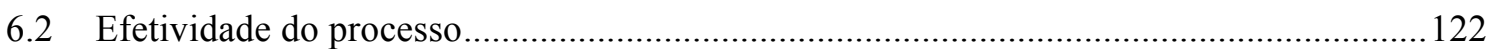

6.3 Da razoável duração do processo e das causas da morosidade atualmente verificada......126

6.4 Adequação do processo como forma de promover a efetividade...................................... 134

6.4.1 Segue: especificamente em relação à recorribilidade das decisões interlocutórias ... 136

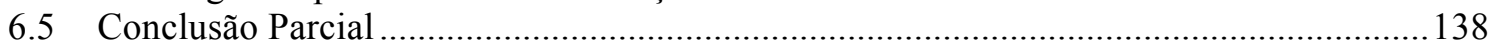

7 A Respeito da Proposta de Novo Código de Processo CiviL ................................. 142

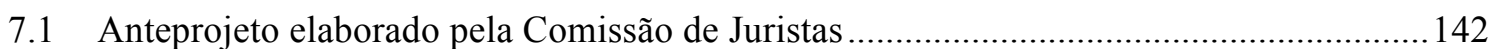

7.2 Substitutivo aprovado no Senado Federal e tramitação na Câmara dos Deputados .......... 143

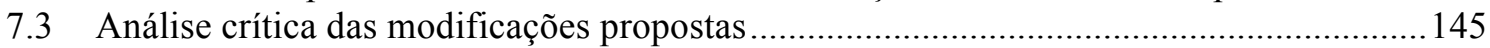

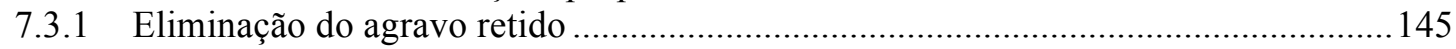


7.3.2 Elenco "taxativo" das hipóteses de cabimento do agravo de instrumento....................147

7.3.3 Do ponto de vista da aproximação com o processo oral..............................................151

7.3.4 Do ponto de vista da modificação do sistema de preclusões ......................................152

7.4 Breve análise da evolução legislativa do agravo: comparação entre os regimes dos Códigos de Processo Civil de 1939, 1973, o Anteprojeto e o Projeto de novo Código de Processo Civil

7.4.1 O problema da utilização anômala de outros remédios processuais como sucedâneos do recurso contra as decisões interlocutórias

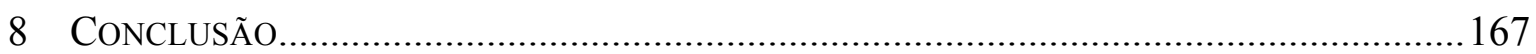

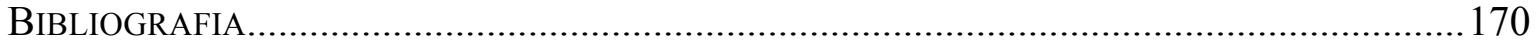

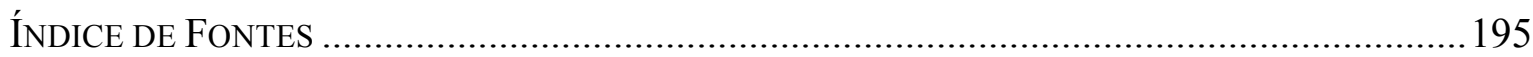




\section{INTRODUÇÃo}

Parafraseando ENRICO AlloRIO, não é fácil fazer a defesa de um instituto jurídico que ninguém pensa realmente em abolir e, portanto, não se propõe em concreto suprimir ${ }^{1}$.

Isso porque, importante deixar claro desde já, ao contrário do que se poderia imaginar inicialmente, nenhuma reforma proposta até o presente momento pretendeu eliminar em definitivo o recurso contra decisões interlocutórias, mas apenas alterar o regime de recorribilidade plena que vige atualmente.

Seja como for, a circunstância de o recurso de agravo ter sido objeto de três reformas no período de uma década (entre 1995 e 2005) e ser novamente alvo de proposta de mudança legislativa revela descontentamento com o atual sistema de recorribilidade das decisões interlocutórias.

Analisando a questão a partir de outro ângulo, observa-se que a efetividade da tutela jurisdicional é tema recorrente em matéria de reformas em geral, e em especial quando se trata do regime de agravos.

O presente trabalho se propõe a estudar precisamente a relação entre esse regime de recorribilidade de decisões interlocutórias e a efetividade da tutela jurisdicional, buscando compreender se as alterações legislativas já realizadas e as que estão sendo propostas terão o condão de atingir os fins a que se destinam em tese, conferindo ao procedimento maior celeridade e efetividade, fazendo com que alcance o maior aproveitamento possível dos atos processuais.

A preocupação em fazer do processo método de resolução de controvérsias cada vez mais efetivo está há bastante tempo na pauta dos estudiosos da matéria, mas não parece ter perdido sua atualidade, tendo sido uma das motivações para a proposta de modificação do sistema de recorribilidade de decisões interlocutórias contida no

\footnotetext{
${ }^{1}$ Tradução livre. Original em italiano: "non è comodo intessere l'apologia di un istituto normativo che nessuno ha davvero in mente di abolire e quindi propone in concreto di sopprimere". Sul doppio grado del processo civile, in Studi in onore di Enrico Tullio Liebman, v. 3, 1ª edição, Milão, Giuffrè, 1979, p. 1784.
} 
anteprojeto de Código de Processo Civil, convertido nos Projetos de Lei n ${ }^{\circ}$ 166/2010, já aprovado no Senado Federal, e $n^{\circ} 8046 / 2010$, atualmente em trâmite na Câmara dos Deputados.

Para tanto, far-se-á análise do papel dos recursos no sistema processual. A partir da definição de qual seja a função dos recursos de um modo geral, procura-se verificar se há a necessidade de se manter no sistema processual um meio destinado especificamente à impugnação das decisões interlocutórias - quer imediata quer mediatamente. Para a adequada compreensão do tema, nesse mesmo capítulo, trata-se, ainda que brevemente, dos princípios que regem a matéria recursal, em especial do princípio do duplo grau de jurisdição e da relação entre os pronunciamentos judiciais e os recursos adequados para impugná-los.

O terceiro capítulo trata do estudo do recurso de agravo, a partir das seguintes perspectivas: (i) do agravo como recurso para a impugnação de decisões interlocutórias por excelência no direito luso-brasileiro; (ii) do regime do agravo, tal como disciplinado hoje pelo Código de Processo Civil, em que é ampla a recorribilidade; (iii) da fórmula que permite distinguir se o recurso cabível é o de agravo de instrumento ou retido, e hipóteses em que o agravo será sempre de instrumento; e (iv) do agravo como recurso tipicamente luso-brasileiro, contrastando-o com o direito francês, em que o recurso de apelação é utilizado para a impugnação de decisões interlocutórias.

A seguir, analisa-se a relação entre a (im)possibilidade de o juiz rever suas próprias decisões e a necessidade de se prever mecanismos de impugnação desses atos decisórios, para definir a importância sistemática do recurso de agravo retido, a partir de contraste com o sistema processual italiano - no qual existe a previsão expressa de irrecorribilidade de certo tipo de decisão que pode, a qualquer momento, ser revogada pelo próprio órgão prolator, independentemente de provocação.

Posteriormente, a atenção se foca no estudo do modelo de processo oral preconizado por CHIOVENDA, que prevê como um de seus corolários justamente a irrecorribilidade em separado das decisões interlocutórias. Analisa-se a possibilidade de adaptar o modelo teórico idealizado pelo processualista italiano às particularidades da realidade brasileira, de modo a que se aproveitem as vantagens que aquela construção teórica que tanta influência exerceu no começo do século XX proporcionaria. Para tanto, 
parte-se da experiência dos Juizados Especiais Cíveis e da Justiça do Trabalho, microssistemas que implementaram normas de inspiração chiovendiana nesse ponto especialmente em relação à obtenção das vantagens que adviriam da oralidade.

Com isso, encerra-se a parte do trabalho que trata especificamente do agravo de instrumento, para se passar a cuidar do problema da efetividade da tutela jurisdicional. Aqui, foca-se na tendência a encarar o processo civil como método de trabalho que deve ser útil, não só no sentido de oferecer prestação jurisdicional adequada, mas também de oferecê-la em tempo razoável, sem dilações desnecessárias.

Outro foco é o estudo da maneira como essa tendência tem sido interpretada pelo legislador, que tende a propor reformas legislativas para problemas que muitas vezes têm origem (e, via de consequência, solução) fora do processo. Novamente, nesse momento, tenta-se estabelecer a relação entre o sistema de recorribilidade das decisões interlocutórias e a efetividade que se espera do processo civil, mas desta vez do ponto de vista deste último aspecto.

Por fim, o trabalho examina a proposta de novo Código de Processo Civil, analisando criticamente tanto o Anteprojeto elaborado pela Comissão de Juristas como o Projeto aprovado no Senado Federal (PL 166/2010 no Senado) e sua tramitação atual na Câmara dos Deputados (PL 8046/2010 na Câmara), comparando-os e contrastando-os. Ainda, trata-se do problema da utilização anômala de sucedâneos recursais, por vezes associado à limitação da recorribilidade das decisões interlocutórias. Ao final, realiza-se ainda breve evolução histórica do recurso de agravo, comparando as formas pelas quais já foi disciplinado desde 1939 até o momento com os projetos mencionados para, então, concluir. 


\section{PAPEL DOS RECURSOS NO SISTEMA PROCESSUAL}

\subsection{RECURSOS COMO MECANISMOS DE REVISÃo DOS PRONUNCIAMENTOS JUDICIAIS}

Para delimitar o objeto deste estudo, necessário ressalvar que, conquanto a palavra recurso possa ser utilizada para fazer referência, de maneira genérica, a todo meio de defesa ou de preservação de direito ${ }^{2}$, a acepção que aqui interessa é a que diz respeito ao mecanismo pelo qual a parte (ou terceiro) manifesta seu inconformismo em relação a determinado pronunciamento judicial ${ }^{3}$, e requer novo julgamento que o anule, reforme, complemente ou esclareça 4 .

A noção de recurso contém em si a ideia de um retorno a estado anterior à prolação da decisão impugnada ${ }^{5}$, para que outra seja proferida, caracterizado pela maior parte da doutrina como ônus relacionado à extensão do direito de ação ${ }^{6}$.

\footnotetext{
${ }^{2}$ Conforme ensina A. MENDONÇA LiMA: "Na linguagem jurídica e, sobretudo, processual, o termo 'recurso' é empregado para indicar todo e qualquer meio com o fim de defender ou preservar um direito. A ação, a contestação, a exceção, a reconvenção, as medidas preventivas, certos institutos com denominação específica (embargos de terceiro e embargos do devedor) etc., podem caber na conceituação genérica de recursos. É um modo de impetrar proteção, auxílio, guarda, ajuda, assim como os crentes recorrem a Deus." Introdução aos recursos cíveis, $2^{\mathrm{a}}$ edição, São Paulo, Revista dos Tribunais, 1976, p. 124.
}

3 "Recurso é, pois, o poder de provocar o reexame de uma decisão, pela mesma autoridade judiciária, ou por outra hierarquicamente superior, visando a obter a sua reforma ou modificação." M. AMARAL SANTOS, Primeiras linhas de direito processual civil, v. 3, 24 a edição, atualizada por Maria Beatriz Amaral Santos Köhnen, São Paulo, Saraiva, 2010, p. 84 - grifo do original.

De maneira semelhante, F. C. PONTES DE MIRANDA: "[e]m sentido lato, recorrer significa comunicar vontade de que o feito, ou parte do feito, continue conhecido, não se tendo, portanto, como definitiva, a cognição incompleta, ou completa, que se operara." Comentários ao Código de Processo Civil, tomo VII, $3^{\mathrm{a}}$ edição, revista e aumentada, Rio de Janeiro, Forense, 2002, p. 2.

${ }^{4}$ Complementação e esclarecimento são consequências passíveis de serem alcançadas pela oposição de embargos de declaração, cabíveis nas hipóteses em que os pronunciamentos judiciais contêm omissão, obscuridade ou contradição. Há, contudo, quem conteste seu caráter recursal, como, por exemplo, E. D. MONIZ DE ARAGÃO: "Sobre os embargos de declaração teço breve comentário. Formo entre os que não os têm na conta de recurso, sim de mecanismo necessário ao esclarecimento e eventual complementação de julgamentos obscuros, contraditórios ou lacunosos." Demasiados recursos? in A. F. FABRICIO, (coord.), Meios de impugnação ao julgado civil - estudos em homenagem a José Carlos Barbosa Moreira, Rio de Janeiro, Forense, 2007, p. 196.

5 "Daí, desta idéia de reexame, é que se explica o vocábulo recurso, originário do verbo recursare $e_{y}$ que em latim significa correr para trás ou correr para o lugar de onde se veio (re + cursus). Sendo o processo um progredir ordenado no sentido de obter-se com a sentença a prestação da tutela jurisdicional que se busca, o recurso corresponderá sempre a um retorno (um recursus) no sentido de refluxo sobre o próprio percurso do processo, a partir daquilo que se decidiu para trás, a fim de que se reexamine a legitimidade e os próprios 
Para expressar o mencionado inconformismo, a parte dispõe de duas ordens de remédios processuais ${ }^{7}$ : aqueles que se exercitam na mesma relação processual e aqueles que se fazem mediante a propositura de ação autônoma ${ }^{8}$. A opção por um ou por outro não decorre de simples faculdade, devendo, tanto aqueles como estas, obedecer aos requisitos previstos em lei.

fundamentos da decisão impugnada.” O. A. BAPTISTA DA SiLvA, Curso de Processo Civil, v. 1, $6^{\text {a }}$ edição, São Paulo, Revista dos Tribunais, 2003, p. 405.

${ }^{6}$ Relata C. B. ESTEVES que "[m]uito se discutiu a respeito da natureza do recurso, mas, atualmente, o entendimento de que o recurso consistiria em ação autônoma e independente foi majoritariamente superado pelo entendimento de que o recurso consiste em uma extensão ou um aspecto do direito de ação." (Ir)recorribilidade imediata de decisões interlocutórias: análise crítica de suas consequências no processo civil brasileiro e proposta para o alcance da efetividade da tutela jurisdicional, tese (doutorado em Direito Processual), Faculdade de Direito - Universidade de São Paulo, São Paulo, 2006, p. 36.

Nesse sentido, J. C. BARBosA MoreiRA explica que "[n]ão obsta a esse entendimento a interponibilidade de recurso pelo réu: tenha-se em mente o caráter bilateral da ação. Restariam os casos em que se faculta o recurso a terceiros prejudicados, ou ao Ministério Público ainda quando não seja parte (art. 499, $\S 2^{\circ}$, fine). Aí, o que se tem de entender é que o recorrente exerce por essa forma abreviada o direito de ação, que não quis, ou não pôde exercer pela forma normal." Comentários ao Código de Processo Civil, v. 5, $7^{\mathrm{a}}$ edição, Rio de Janeiro, Forense, 1998., p. 234, grifos do original.

Assim também C. SCARPINELLA BUENO: "O recurso é, assim, um direito - um 'direito subjetivo público' exercitado pelas partes (autor e réu) e pelos terceiros, representando verdadeiro desdobramento do direito de ação (e do direito de defesa) que permeia o desenvolvimento de todo o processo - do mesmo processo (v. n. 3 , infra) -, até a obtenção da tutela jurisdicional para aquele que, na ótica dos órgãos jurisdicionais, detém em face de outrem posição jurídica de vantagem no plano material. Não se trata, destarte, de uma nova ação, mas da mesma, originalmente exercitada, que é renovada, desdobrada, exercitada ao longo do processo com vistas à obtenção de uma específica situação de vantagem e que, pelas razões expostas no n. 1 do Capítulo 2 da Parte III do vol. 1, é também exercitável pelo réu, ainda que sob as vestes de um 'direito de defesa', e por eventuais terceiros intervenientes." Curso sistematizado de Direito Processual Civil, v. 5, São Paulo, Saraiva, 2008, pp. 9-10 - grifos do original.

Em sentido contrário, O. N. S. LASPRO, citando VIGORITI, para quem "a possibilidade de recorrer não é uma obrigação constitucional do legislador, mas se encontra dentro do seu poder discricionário, como 'matter of grace" pois " $[0]$ processo desenvolvido em primeira instância no sistema brasileiro permite uma cognição plena e uma participação efetiva das partes, via garantia do contraditório. Assim, a admissibilidade de impugnar uma decisão não pode ser enquadrada como uma garantia ao direito de ação ou de defesa, vez que estes são amplamente garantidos na sistemática vigente." Oralidade e duplo grau de jurisdição, Revista do advogado, 40:1993, p. 53.

7 “'Os mecanismos de que podem se valer as partes para impugnar uma decisão judicial são denominados pela doutrina, genericamente, de remédios processuais. Tais remédios processuais ora consistem em recursos, ora em ações impugnativas autônomas. A nota característica dos recursos é o fato de serem exercitáveis na mesma relação jurídica processual em que foi proferida a decisão impugnada". T. A. A. WAMBIER, J. M. Garcia MedinA, Recursos e Ações Autônomas de Impugnação, v. 2, coleção Processo Civil Moderno, São Paulo, Revista dos Tribunais, 2008, p. 27 - grifos do original.

${ }^{8}$ Para A. DE Assis, "[a] impugnação às decisões judiciais, no direito brasileiro, ultrapassa o quadro dos recursos e das ações autônomas. À margem desses mecanismos, as partes utilizam com inaudita desenvoltura expedientes variados e de natureza heterogênea para eliminar o gravame imposto pelas resoluções do órgão judiciário. O conjunto desses meios extravagantes recebe o nome de 'sucedâneos recursais'." Manual dos Recursos, $1^{a}$ edição, São Paulo, Revista dos Tribunais, 2007, p. 35. O jurista identifica as seguintes espécies de sucedâneos recursais: reexame necessário, correição parcial, pedido de reconsideração, suspensão da liminar e agravo regimental (cf. Manual cit., capítulo 15), afirmando que seu "objetivo é unívoco e idêntico ao dos recursos: a reforma ou a invalidação do ato.” Manual cit., p. 835. 
Seja como for, é traço característico dos recursos no ordenamento brasileiro a instauração de novo procedimento ${ }^{9}$ no mesmo processo, sem a propositura de outra ação ${ }^{10}$. Outra característica comum aos recursos, que consiste no mais amplo efeito que decorre da sua interposição é impedir (ou, quando menos, retardar) a ocorrência da preclusão $^{11}$, e adiar o trânsito em julgado ${ }^{12}$.

O que até aqui se afirmou evidencia que é também inerente à noção de recurso o ataque voluntário do sujeito processual (ou de terceiro juridicamente interessado) a determinada decisão. Com isso, ficam excluídos mecanismos de revisão de decisões judiciais que independem da manifestação de vontade da parte, como o reexame necessário previsto para os julgamentos desfavoráveis à Fazenda Pública ${ }^{13}$.

A justificativa para esta exclusão reside basicamente em que a interposição de recurso é ônus que compete unicamente ao juridicamente interessado (aquele que foi prejudicado pela decisão). Isto porque, por exemplo, a parte pode deixar de impugnar sentença contrária aos seus interesses, por considerá-la justa, ou mesmo por entender que

\footnotetext{
${ }^{9}$ Ressalta J. C. BARBOSA MOREIRA que os recursos são remédios exercitáveis "dentro do mesmo processo, não necessariamente dos mesmos autos. A interposição do agravo por instrumento dá lugar à formação de autos apartados; bifurca-se o procedimento, mas o processo permanece uno, com a peculiaridade de pender, simultaneamente, no primeiro e no segundo grau de jurisdição." Porém, em outros ordenamentos, a distinção entre recursos e ações autônomas de impugnação se dá pela "relação de cada uma delas com a coisa julgada". E complementa: "Essa linha divisória logicamente deveria apagar-se nos ordenamentos influenciados pela tendência, que a partir de certa época se difundiu, a converter em simples razões de recorribilidade os motivos que antes levavam à invalidação da sentença: a consequência seria a absorção das ações impugnativas autônomas pelos recursos. Manteve-se a separação, contudo, sob forma diversa: a da distinção, que em alguns países se veio a consagrar, entre recursos ordinários e extraordinários, aqueles obstativos do trânsito em julgado, estes utilizáveis contra decisões já revestidas da auctoritas rei iudicatae. Do ponto de vista substancial, os 'recursos extraordinários', em tais sistemas, desempenham função análoga à das ações autônomas de impugnação." Comentários cit., p. 231 e 229, respectivamente - grifos do original.

10 “Não ministra o Código de Processo Civil uma definição de 'recurso'; examinando-se, porém, as várias figuras ali arroladas sob esse nomen iuris, verifica-se que o denominador comum de todas elas consiste em que o seu uso não dá margem à instauração de novo processo, senão que apenas produz a extensão do mesmo processo até então fluente.” J. C. BARBOSA MOREIRA, Comentários cit., p. 230 - grifos do original.

${ }^{11}$ Cf. C. R. Dinamarco, Os efeitos dos recursos in Nova era do Processo Civil, $1^{\text {a }}$ edição, São Paulo, Malheiros, 2003, p. 109.

${ }^{12}$ Cf. J. C. BArbosa Moreira, Comentários cit., p. 228, A. DE Assis, Manual cit., p. 32.

${ }^{13}$ Cf. art. 475 do CPC. A. de AsSis critica esta exclusão: “[p]õe-se excessivo destaque no caráter voluntário de todo recurso, olvidando seu eventual regime compulsório. E até mesmo a voluntariedade surge no recurso ex officio." Manual cit., p. 853. Para ele, “o art. 475, caput, manteve a velha e incompreendida apelação ex officio." Manual cit., p. 852.
} 
com isso poderá obter alguma vantagem futura; e pode também optar por impugnar apenas parcialmente a decisão ${ }^{14}$.

Em complemento, tem-se que os recursos são meios de impugnação de iniciativa da parte, a cargo do mesmo órgão prolator da decisão ou de outro de hierarquia superior. Ao lesado, basta a indicação de que a decisão padece de vício para que o próprio Poder Judiciário cuide de verificar se é o caso de reformá-la ${ }^{15}$.

Existe ainda discussão doutrinária - que, contudo, aqui é apenas registrada, por não se enquadrar no objeto do estudo - a respeito da necessidade de devolução da matéria impugnada para outro órgão jurisdicional (de mesma ou de diferente hierarquia) a fim de caracterizar-se o recurso ${ }^{16}$.

Em suma, são características fundamentais dos recursos, de um lado, serem atos voluntários pelos quais as partes requerem a prolação de nova decisão a respeito de determinada(s) questão(ões) e, de outro, conduzirem à instauração de novo procedimento dentro do mesmo processo ${ }^{17}$. Com isso, excluem-se em princípio ações autônomas (mandado de segurança, cautelares inominadas), e sucedâneos recursais (correição parcial, pedidos de reconsideração), embora se vá tratar brevemente desses meios de impugnação adiante (tópico 7.4.1).

\footnotetext{
${ }^{14}$ Nesse sentido é a lição de F. CARNELUTTI, para quem "[a] impugnação do procedimento não se pode fazer nunca de ofício, não porque non intersit republicae a verificação da justiça da sentença, mas porque a aquiescência das partes é indicativo ou de sua justiça, ou da tolerância de sua injustiça, no sentido de que sua reparação não vale o custo da renovação do procedimento." Instituições do Processo Civil, v. 2, trad. Adrián Sotero De Witt Batista, $1^{\text {a }}$ edição, São Paulo, Classic Book, 2000, p. 212 - grifos do original.

${ }^{15}$ Assim ensina E. J. COUTURE: "los recursos no son propiamente medios de subsanación a cargo de la parte, sino que son medios de subsanación que funcionan por iniciativa de la parte y a cargo del mismo juez (reposición) o de otro juez superior (apelación, nulidad)." E prossegue: "La parte lesionada se limita generalmente a una simple acusación: acusa o tacha la sentencia de injusta o de nula. De allí en adelante, la anulación o la revocación no serán actos de parte, sino actos del mismo o de otro juez. La parte destaca los vicios de la sentencia para que sean los propios órganos del Poder Judicial quienes los corrijan." Fundamentos del Derecho Procesal Civil, $3^{\text {a }}$ edição (póstuma), Buenos Aires, Roque Depalma, 1958, p. 350 - grifo do original.

${ }^{16}$ O. A. BAPTISTA DA Silva acena nesse sentido, ao tratar da organização hierárquica segundo a qual é estruturado o Poder Judiciário, especificamente para tratar do duplo grau de jurisdição, de que se cuidará adiante. Curso cit., p. 405.

${ }^{17}$ Assim A. MENDONÇA LiMA, para quem "Recurso é o meio, dentro da mesma relação processual, de que se pode servir a parte vencida em sua pretensão ou quem se julgue prejudicado, para obter a anulação ou a reforma, parcial ou total, de uma decisão”. Introdução cit., p. 125 - grifo do original.

No mesmo sentido, J. C. BARBOSA MOREIRA: “À luz das considerações acima, pode-se conceituar recurso, no direito processual civil brasileiro, como o remédio voluntário idôneo a ensejar, dentro do mesmo processo, a reforma, a invalidação, o esclarecimento ou a integração de decisão judicial que se impugna." Comentários cit., p. 231.
} 
Prosseguindo-se no raciocínio, pode-se identificar três principais razões jurídicas pelas quais se justifica a existência de recursos no sistema processual ${ }^{18}$.

A primeira diz-se de ordem psicológica, relacionada com a dificuldade do homem de conviver com decisão que lhe seja desfavorável, que conduz ao desejo de ter a questão submetida a novo julgamento ${ }^{19}$. Justamente por se tratar de anseio inerente à condição humana, MENDONÇA LIMA explica que, até mesmo nas mais antigas civilizações, quando se podia identificar organização social tal que conhecesse a noção de hierarquia, estava presente alguma forma de recurso, ainda que sem as formas e a sofisticação que os caracterizam atualmente ${ }^{20}$.

Do ponto de vista individual, portanto, a ideia de recurso está diretamente associada à sensação de injustiça experimentada por quem sai vencido em determinado processo. Destaca-se que não se está tratando aqui da lesão verificada no plano do direito material; a sensação de injustiça a que se faz referência é-lhe posterior, pois surge apenas em decorrência da insatisfação com o resultado de processo judicial, aqui entendido como método estatal para a pacificação de conflitos sociais com justiça ${ }^{21}$.

\footnotetext{
18 “A doutrina aponta três fundamentos que justificam a existência de recursos contra decisões judiciais em um sistema jurídico: $1^{\circ}$ ) o inconformismo das partes quanto à decisão proferida contrariamente a seu interesse $2^{\circ}$ ) o interesse do próprio Estado em que a decisão seja proferida corretamente; e $3^{\circ}$ ) em alguns sistemas jurídicos, como o brasileiro, a necessidade de uniformização da inteligência do direito federal." $T$. A. A. Wambier, J. M. Garcia Medina, Recursos cit., p. 27.

19 “A ideia de recurso está estreitamente associada à própria reação psicológica do homem diante do fato desfavorável da vida social ou da vida jurídica que lhe acarreta um prejuízo qualquer, assim como a noção de remédio encontra-se intimamente ligada à ocorrência de um mal na vida biológica." C. S. NORONHA, Do agravo de instrumento, $3^{\text {a }}$ edição, Rio de Janeiro, Forense, 1995, p. 109.

20 "Do ponto de vista jurídico-processual, não se trata de determinar o recurso como instituição organizada, em moldes solenes e formas exatas. Isso somente seria possível com o desenvolvimento natural da civilização. O fato importante, sem dúvida, é o de estabelecer, nas fontes históricas, que, em essência, a ideia de recurso se acha arraigada no espírito humano, como uma tendência inata e irresistível, como uma decorrência lógica do próprio sentimento de salvaguarda a um direito já ameaçado ou violado em uma decisão. Os meios de reparação tinham de ser primitivos e, até, amorfos, como o eram as demais instituições sociais, que o desenrolar de milênios aperfeiçoaria e consolidaria." Introdução cit., pp. 3-4.
}

No mesmo sentido, R. ORESTANO: “diremo 'appello' quel mezzo processuale (e il procedimento cui esso dà luogo) che offra la possibilità di ottenere la pronunzia di una nuova decisione - e quindi di una nuova sentenza - su una lite già conchiusa con una precedente sentenza valida." L'appello civile in diritto romano, $2^{\mathrm{a}}$ edição ampliada, Turim, G. Giappichelli, 1953, p. 77.

${ }^{21}$ Assim se conclui ao se conjugar as ideias de que "Processo nada mais é, pois que um método de trabalho desenvolvido pelo Estado para permitir a solução dos litígios" (J. R. S. BEDAQUE, Efetividade do processo e técnica processual, $3^{\mathrm{a}}$ edição, São Paulo, Malheiros, 2010, p. 36) e de que "todo instrumento, como tal, é meio; e todo meio só é tal e se legitima, em função dos fins a que se destina" (C. R. Dinamarco, $A$ instrumentalidade do processo, 14 edição, São Paulo, Malheiros, 2009, 178 - grifos do original). CÂNDIDO DINAMARCO aponta ainda a existência de outros escopos da jurisdição e do processo cuja análise detalhada, contudo, escapa ao objeto deste trabalho. 
Analisando-se a situação por outro ângulo, é possível verificar que o sistema processual também tem interesse em permitir a revisão das decisões judiciais, e por vários motivos.

O mais evidente talvez seja a necessidade de corrigir vícios de que possa padecer a decisão recorrida. Embora se trate - ao menos em teoria - de risco que corresponde à exceção, e não à regra, fato é que toda demanda está sujeita à prolação de decisão injusta, incorreta, em desconformidade com a norma aplicável ${ }^{22}$, pelo simples fato de ser julgada por juiz humano, suscetível de cometer erros ${ }^{23}$.

De maneira geral, tende-se a imaginar que a decisão que já tenha sido objeto de reanálise será "melhor" do que aquela que não o foi. Os recursos seriam meio adequado de atingir esse objetivo na medida em que são julgados por juízes (i) via de regra mais experientes; (ii) que estariam afastados de pressões às quais poderia estar sujeito o julgador de primeiro grau dado o contato mais próximo com as partes; e (iii) que podem se valer da análise já previamente realizada pelo magistrado singular como ponto de partida para redecidir (quer adotando suas premissas ou identificando equívocos).

Ainda, a previsão de meios de impugnação de decisões judiciais teria por função coibir autoritarismo que se pode cogitar viria a existir (ainda que não como regra) caso os julgadores em primeiro grau soubessem que suas decisões não estariam sujeitas a revisão nem poderiam ser reformadas ${ }^{24}$.

\footnotetext{
${ }^{22}$ Aparentemente em sentido contrário, O. BAPTISTA DA SILVA afirma que a existência de recursos seria "viés autoritário" do sistema processual, por estar assentada em premissa que reputa incorreta: "como pensamos pela epistemologia do 'certo' e do 'errado', dizendo que o juiz deve descobrir a 'vontade da lei', estaremos pressupondo que possa haver apenas uma 'vontade da lei' a ser revelada na sentença. Por força de nosso férreo dogmatismo, não nos é dado admitir que a lei, sendo hermeneuticamente interpretada, possa deixar ao magistrado uma margem de liberdade que lhe permita fazer o Direito progredir, harmonizando-o com as novas realidades sociais e históricas, capazes de revelar agora, 'outra vontade' da lei." Os recursos - viés autoritário da jurisdição in Processo e ideologia: o paradigma racionalista, $2^{\mathrm{a}}$ edição, Rio de Janeiro, Forense, 2006, p. 244.

${ }^{23}$ É como explica J. C. BARBOSA MOREIRA: "Ante a inafastável possibilidade do erro judicial, adotam as leis posição intermediária: propiciam remédios, mas limitam-lhes os casos e as oportunidades de uso." Comentários cit., 1998, p. 227.

24 'L'esigenza d'una sentenza giusta non è posta, conseguentemente, tanto in relazione al privato interesse delle parti ed ai loro diritti soggettivi, quanto all'interesse dello Stato, rispetto al quale la giustizia è una esigenza costituzionale ed una condizione di conservazione e di progresso, e, per conseguenza ulteriore, sentenza giusta è quella che sia conforme alla legge dello Stato (che esercita la giurisdizione), non potendosi ammettere alcuna norma di giustizia diversa da quella derivante dal diritto dello Stato." R. ProvinCIALI, Tratatto del Processo Civile direto da Francesco Carnelutti - Delle impugnazione in generale, Nápoles, Morano, 1962, p. 12.
} 
Outrossim, em outro nível, recursos se prestam a uniformizar entendimentos, de modo que situações semelhantes não venham a receber tratamentos discrepantes - o que reduziria a confiança no processo, gerando problema de legitimidade das decisões ${ }^{25}$.

Há ainda fundamento de ordem política a justificar a existência dos recursos, qual seja, a necessidade de controle dos atos estatais como postulado do Estado de direito ${ }^{26}$. Cuida-se de garantia contra o arbítrio mais abrangente do que a já mencionada, pois abrange todos os atos estatais, e não somente as decisões proferidas em processos judiciais $^{27}$.

As ponderações acima, e resumem brevemente as razões que justificam a existência de recursos no sistema ${ }^{28}$. Porém, para que se possa também atender ao objetivo de pacificação social, os valores mencionados devem ser conciliados com o princípio da segurança jurídica, e a decorrente necessidade prática de que o processo não só venha a ter fim, como que se desenvolva com a brevidade possível ${ }^{29}$.

\footnotetext{
25 "Em alguns meios de impugnação, o objetivo fundamental é o único que importa: o remédio promove, concretamente, a supremacia da Constituição ou controla a exata aplicação das leis. A maioria das impugnações sobreleva o interesse em reavaliar a justiça do provimento, sem prejuízo, no entanto, da finalidade pública há pouco reconhecida ao instituto.” A. DE AsSIS, Manual cit., p. 32.

${ }^{26}$ Assim ensina A. P. GRINOVER: "É aqui que entra poderoso argumento de índole política e militar em favor da preservação do duplo grau: nenhum ato estatal pode escapar de controle. A revisão das decisões judiciárias - que configuram ato autoritativo estatal, de observância obrigatória para as partes e com eficácia natural em relação a terceiros - é postulado do Estado de direito." E prossegue: "Trata-se de controle interno, exercido por órgãos da jurisdição diversos do que julgou em primeiro grau, a aferirem a legalidade e a justiça da decisão por este proferida." Um enfoque constitucional da teoria geral dos recursos in $O$ processo em evolução, $1^{\text {a }}$ edição, Rio de Janeiro, Forense Universitária, 1996, p. 65 - grifo do original.

${ }^{27}$ Discorda desse posicionamento O. N. S. LASPRO: "Quanto àquela razão política, que equipara o ato jurisdicional a um ato administrativo qualquer e, portanto, sujeito à fiscalização e à impugnação, entendemos, seguindo Pizzorusso, que parte de premissa equivocada. Em primeiro lugar, porque a possibilidade de impugnação dos atos jurisdicionais é historicamente muito anterior àquela dos atos administrativos e legislativos e, em segundo lugar, os atos jurisdicionais devem ser obrigatoriamente motivados, ao contrário dos outros." Oralidade e duplo grau de jurisdição, Revista do Advogado, São Paulo, 40:1993, p. 52.
}

${ }^{28}$ A esse respeito, bem sintetiza R. Provinciali que "L'impugnabilità involge, invece, un concetto di controlo sul contenuto dell'atto in relazione al diritto in base al quale è posto in essere, vale a dire in ordine ala sua conformità a diritto: cioè ala sua giustizia. (...) Lo strumento onde si perviene a questo controllo, è l'impugnazione, che funziona in vari sensi: rimozione, modificazione, riforma, sostituzione; funzioni tutte che rappresentano altrettante fasi della reattività dell'impugnazione sull'atto impugnato." Trattato cit., p. 14.

29 "À conveniência da rápida composição dos litígios, para o pronto restabelecimento da ordem social, contrapõe-se o anseio de garantir, na medida do possível, a conformidade da solução ao direito. Entre essas duas solicitações, até certo ponto antagônicas, procuram os ordenamentos uma via média que não sacrifique, além do limite razoável, a segurança à justiça, ou esta àquela. Fazer inimpugnáveis quaisquer decisões, desde que proferidas, atenderia ao primeiro interesse, mas com insuportável detrimento do segundo; multiplicar ad infinitum os meios de impugnação produziria efeito diametralmente oposto e igualmente danoso. Ante a 
Para tanto, os ordenamentos tendem a adotar soluções de compromisso, estipulando uma série limitada de recursos às quais está sujeito determinado pronunciamento judicial. Nesse cenário, tanto a interposição, pela parte, de todos os recursos disponíveis quanto a aceitação tácita do conteúdo de determinada decisão (que decorre da inércia em recorrer) são mecanismos de que se pode valer o jurisdicionado para conduzir à imutabilidade do pronunciamento judicial ${ }^{30}$.

\subsection{SEGUE: NECESSIDADE DO RECURSO DE AGRAVO NO SISTEMA PROCESSUAL}

As considerações do tópico anterior a respeito das razões que justificam a previsão de recursos no sistema processual civil conduzem à reflexão acerca da necessidade de mecanismos de revisão de decisões interlocutórias para que o processo atinja os fins aos quais se destina.

Inicia-se esta análise a partir da constatação de que diversos e importantes institutos processuais são delineados não pela legislação ordinária, mas pela própria Constituição Federal, que institui princípios como juiz natural, contraditório, devido processo legal e ampla defesa (art. $5^{\circ}$, LIV e LV)

Aliás, é de se observar que essa última é prevista "com os meios e recursos a ela inerentes”. Portanto, é possível concluir que a garantia constitucional da ampla defesa engloba também os meios de impugnação de decisões judiciais no mesmo processo ${ }^{32}$, embora se admita a possibilidade de a palavra "recurso" ter mais de um significado, como já se mencionou.

inafastável possibilidade do erro judicial, adotam as leis posição intermediária: propiciam remédios, mas limitam-lhes os casos e as oportunidades de uso.” J. C. BARBosa MoreIRA, Comentários cit., p. 227.

30 “....) la serie delle impugnazioni - o, più precisamente, il fatto che si tratti di una serie limitata (e cioè la serie dei mezzi elencati nell'art. 324 c.p.c.) - è lo strumento tecnico del quale l'ordinamento si serve per conseguire l'incontrovertibilità della pronuncia, vuoi attraverso l'esercizio effettivo dell'intera serie delle impugnazioni, vuoi attraverso la implicita accettazione della pronuncia (o di una delle pronunce della serie), a seguito del mancato esercizio del potere di impugnazione." C. MANDRIOLI, Corso di Diritto Processuale Civile, v. 2, Editio Minor, Torino, G. Giappichelli, 2000, p. 238. No mesmo sentido, A. P. GRINOVER, Os princípios constitucionais e o Código de Processo Civil, São Paulo, Bushatsky, 1975, p. 137.

${ }^{31}$ Nesse sentido, S. F. TEIXEIRA: “O Direito Processual tem seus alicerces no Direito Constitucional, que lhe fixa as linhas essenciais, principalmente quanto ao direito de ação e de defesa, ao exercício da jurisdição". $O$ processo civil na nova Constituição, Justitia, São Paulo, 50:1988, p. 93.

${ }^{32}$ Cf. E. D. Moniz DE ARAGÃo, Demasiados recursos? cit., p. 187. 
Nesse ponto, importante destacar que, sendo a Constituição o retrato dos pré-compromissos assumidos pelo povo, a circunstância de constarem tais previsões em seu texto revela que possuem valor intrínseco, não se tratando apenas de disposições técnicas $^{33}$. Dessa forma, eventuais modificações no sistema recursal, conquanto possíveis, encontram limite no texto da Constituição Federal, que impede a sua supressão completa.

No que diz respeito ao objeto do presente estudo, destaca-se que há basicamente duas situações nas quais é cabível a interposição de agravo por instrumento: (i) prolação de decisão interlocutória "suscetível de causar à parte lesão grave e de difícil reparação"; e (ii) impossibilidade de postergar a análise do recurso contra a decisão interlocutória para o momento do julgamento da apelação, por já ter sido proferida sentença - ou seja, "casos de inadmissão da apelação e nos relativos aos efeitos em que a apelação é recebida" ${ }^{34}$, bem como para impugnar decisões proferidas em fase de liquidação e cumprimento de sentença.

Outrossim, cada um dos recursos previstos no Código de Processo Civil possui uma finalidade específica.

Assim, de maneira geral, considerando-se ser pressuposto de todo recurso a lesividade da decisão recorrida ${ }^{35}$, observa-se que o agravo possui dupla função no sistema processual. Primeiro, evitar que ocorra a preclusão sobre determinada questão, permitindo seu reexame, imediatamente ou quando da eventual interposição do recurso de apelação.

Segundo, controlar a atividade jurisdicional ao longo do processo, oferecendo à parte lesada por decisão interlocutória (ou sentença que inadmita o recurso de

\footnotetext{
${ }^{33}$ N. NERY explica: “A Constituição é a ordem jurídica fundamental da coletividade: determina os princípios diretivos, segundo os quais devem formar-se a unidade política e as tarefas estatais a serem exercidas; regula ainda procedimentos de pacificação de conflitos no interior da sociedade; para isso cria bases e normaliza traços fundamentais da ordem total jurídica.”. Princípios do Processo na Constituição Federal, 9a edição, revista, ampliada e atualizada com as novas Súmulas do STF (simples e vinculantes) e com análise sobre a relativização da coisa julgada, São Paulo, Revista dos Tribunais, 2009, p. 38 - grifo do original.

${ }^{34}$ Art. 522 do Código de Processo Civil, com redação dada pela Lei no 11.187, de 2005: “Das decisões interlocutórias caberá agravo, no prazo de 10 (dez) dias, na forma retida, salvo quando se tratar de decisão suscetível de causar à parte lesão grave e de difícil reparação, bem como nos casos de inadmissão da apelação e nos relativos aos efeitos em que a apelação é recebida, quando será admitida a sua interposição por instrumento."

${ }^{35}$ Cf. J. Frederico MARques, "requisito primordial e básico, inarredável e imperativo, em todo recurso, é a lesividade, para o recorrente. Sem prejuízo ou gravame a direito da parte, não pode esta pretender recorrer." Manual de Direito Processual Civil, v. 3, 2ª edição atualizada, Campinas, Millennium, 1998, p. 171.
} 
apelação também no efeito suspensivo) maneira de impugná-la imediatamente ${ }^{36}$ - ainda que o julgamento do recurso venha a ser postergado para momento posterior.

E, num contexto de crescente preocupação com o dano marginal ${ }^{37}$ causado pela demora na resposta jurisdicional, em que se confere aos juízes cada vez mais poderes para a concessão de provimentos satisfativos da pretensão deduzida na demanda, evidente a importância desse tipo de controle ${ }^{38}$.

Com efeito, a possibilidade de uma das partes vir a obter provimento satisfativo antes mesmo da prolação de sentença, suscetível de ser executado sem que tenha havido trânsito em julgado tem por consequência o risco de se gerar para a parte contrária dano irreparável ou de difícil reparação. Nesse cenário, oferece-se como contrapartida à parte lesada pela possibilidade de vir a ter de cumprir decisão que antecipa os efeitos da tutela a oportunidade de submetê-la a revisão, inclusive imediatamente, se o caso.

Estabelecidas as premissas de que o recurso de agravo é necessário, e de que sua total eliminação não seria viável, nem mesmo interessante, cabe questionar até que ponto seria possível restringir seu cabimento sem ferir a norma constitucional. Para isso, antes de mais nada, importante destacar quais são os princípios relevantes em matéria de recursos.

\footnotetext{
${ }^{36}$ Para E. D. MoniZ DE ARAGÃo, agravos "são essenciais ao controle da atividade desenvolvida ao longo do processo, a fim de acudir a reclamos de quem se sinta atingido por atos praticados durante a tramitação do feito, atos esses que é impossível prever e aprisionar em numerus clausus, como já foi tentado. Recente legislação visou a restringir seu cabimento, limitando-os, quanto possível, ao chamado 'agravo retido', ou seja, cerceando a subida imediata. Reconhece o legislador, porém, a impossibilidade de alcançar tal objetivo e por isso, argutamente, libera o acesso ao órgão superior no caso de o agravo impugnar 'decisão suscetível de causar à parte lesão grave e de difícil reparação', válvula esta que veio restabelecer o vetusto agravo por dano irreparável, que legisladores do passado tentaram eliminar e com isso deram azo ao aparecimento da reclamação, ou correição parcial, e ao emprego do mandado de segurança contra ato judicial.” Demasiados recursos? cit., p. 195.
}

${ }^{37}$ A. PROTO PISANI explica que o dano marginal é aquele decorrente da duração necessária do processo de conhecimento, instrumento sofisticado de resolução de controvérsias, que tem sua própria "fisiologica durata". Essa duração prevista em lei, conquanto necessária para assegurar os direitos e garantias das partes, pode vir a causar dano irreparável ou de difícil reparação a um dos litigantes, daí falar-se em "dano marginal”. Lezioni di Diritto Processuale Civile, 2 edição, Nápoles, Jovene, p. 651 - grifos do original.

${ }^{38}$ Assim A. G. CARNEIRO: "Na realidade processual contemporânea as interlocutórias multiplicam-se, muitas com efeitos os mais relevantes no andamento e na decisão da causa, impondo-se assim a previsão de um recurso que seja útil à parte que razoavelmente invoque prejuízos dela decorrentes." Do recurso de agravo e suas alterações pela lei $n^{o} 11.187 / 05$, in A. F. FABRÍcIO, Meios de impugnação ao julgado civil-estudos em homenagem José Carlos Barbosa Moreira, Rio de Janeiro, 2007. 
Para compreender os recursos de um modo geral e o agravo de modo específico, imprescindível a análise dos princípios que os norteiam. O estudo dos princípios se justifica pois permite individualizar um determinado sistema, diferenciando-o dos demais ${ }^{39}$, vez que todos os ordenamentos são guiados por princípios, alguns comuns e outros específicos.

\subsection{PRINCÍPIOS RELEVANTES EM MATÉRIA DE RECURSOS}

Conforme já se mencionou, o direito processual civil, ramo do direito público, tem vários e importantes institutos delineados pela Constituição Federal ${ }^{40}$, na qual estão insculpidas garantias fundamentais ${ }^{41}$ - o que se revela a partir da análise da relação entre o processo e a Constituição no vetor Constituição-processo, ou seja, da chamada tutela constitucional do processo ${ }^{42}$.

Com efeito, a Constituição representa a base do sistema jurídico nacional, de modo que seus valores se trasladam para a lei ordinária que determina o regime processual $^{43}$, fazendo com que se possa considerar o processo não apenas como método

\footnotetext{
39 “É do exame dos princípios gerais que informam cada sistema que resultará qualificá-lo naquilo que tem de particular e de comum com os demais, do presente e do passado". A. P. GRINOVER, Os princípios cit., 1975, pp. 23-24.

40 “Alguns dos princípios gerais que o informam são, ao menos inicialmente, princípios constitucionais ou seus corolários: em virtude deles, o processo apresenta certos aspectos, como o do juiz natural, o da publicidade das audiências, o da posição do juiz no processo, o da subordinação da jurisdição à lei, o da declaração e atuação do direito objetivo; e, ainda, os poderes do juiz no processo, o direito de ação e de defesa, a função do Ministério Público, a assistência judiciária.” A. C. ARAúJo Cintra, A. P. Grinover, C. R. DinAmARCO, Teoria geral do processo, $25^{\mathrm{a}}$ edição, São Paulo, Malheiros, 2009, p. 84
}

41 " $O$ Estado de direito só pode atingir seu real coroamento através desses instrumentos processualconstitucionais de tutela dos direitos fundamentais do homem. Trata-se, na expressão de COUTURE, de fazer com que o direito não fique à mercê do processo, nem que venha a sucumbir por ausência ou insuficiência deste: porque não há liberdades públicas senão quando se disponha de meios jurídicos que impeçam seu desrespeito; e esses meios se exercem através da função jurisdicional, primacialmente. Já dizia CALAMANDREI que vãs seriam as liberdades do indivíduo, se não pudessem ser reivindicadas e defendidas em juízo: porque os direitos fundamentais, abstratamente formulados pela constituição, só podem ser afirmados, positivados e concretizados pelos tribunais.” A. P. GRINOVER, Os princípios cit., pp. 6-7, grifos do original.

${ }^{42}$ C. R. DinAMARCO ensina que "[a] tutela constitucional do processo tem o significado e escopo de assegurar a conformação dos institutos do direito processual e o seu funcionamento aos princípios que descendem da própria ordem constitucional”. Instrumentalidade cit., pp. 26-27.

${ }^{43}$ Cf. E. J. Couture, Las garantias constitucionales del proceso civil, in Estudios de Derecho Procesal Civil, tomo I, $1^{\text {a }}$ edição, Buenos Aires, Ediar, 1948, p. 21. 
técnico de trabalho, mas também como instrumento ético ${ }^{44}$. O sistema processual contempla ainda princípios próprios, que, por sua pertinência, serão também analisados.

Fugiria ao escopo deste trabalho pretender tratar pormenorizadamente de todos os princípios constitucionais que de alguma forma exercem influência sobre o processo. Assim, procurou-se manter o foco apenas nos princípios essenciais à compreensão dos recursos, merecendo destaque: devido processo legal, taxatividade, unirrecorribilidade, contraditório, ampla defesa, juiz natural, fungibilidade. Por sua relevância para o tema do trabalho, o princípio do duplo grau de jurisdição será tratado em subtópico apartado. Já os subprincípios relativos ao processo oral serão tradados em capítulo próprio, dedicado a este modelo de processo idealizado por CHIOVENDA.

No art. 5', LIV, da Constituição Federal, prevê-se a garantia do devido processo legal ("'ninguém será privado da liberdade ou de seus bens sem o devido processo legal"). Trata-se de princípio constitucional com múltiplos reflexos, mas que estabelece essencialmente que o processo judicial deve ser idôneo, por tal entendendo-se ao mesmo tempo tão ágil e seguro quanto possível. Com isso, conforme explica CoUTURE, o processo, que seria apenas um instrumento de realização da justiça “viene así a constituirse en un derecho de rango similar a la justicia misma" ${ }^{45}$. Trata-se, na realidade, não de um único princípio, mas de um conjunto de garantias constitucionais ${ }^{46}$ ou superprincípio ${ }^{47}$.

O devido processo legal se consubstancia, antes de mais nada, em garantia de legalidade, ou seja, de observância do procedimento estabelecido em lei para o desenvolvimento do processo $^{48}$. Nesse contexto, o princípio desdobra-se em duas outras

\footnotetext{
${ }^{44}$ Cf. A. P. GRINOVER, Os princípios cit., p. 5.

${ }^{45}$ Las garantías cit., p. 23.

46 "Entende-se, com essa fórmula, o conjunto de garantias constitucionais que, de um lado, asseguram às partes o exercício de suas faculdades e poderes processuais e, do outro, são indispensáveis ao correto exercício da jurisdição.” A. C. Araújo Cintra, C. R. Dinamarco, A. P. Grinover, Teoria cit., p. 88.
}

47 Cf. H. THEODORO JR., Processo justo e contraditório dinâmico, disponível em http://www.rechtd.unisinos.br/index.php? $=3 \& \mathrm{~s}=9 \& \mathrm{a}=91$, acesso em 6.7 .2011$, p. 5 .

${ }^{48}$ A. P. GRINOVER explica, com a clareza de sempre, que "a expressão 'devido processo legal', oriunda da Magna Carta de 1215, indica o conjunto de garantias processuais a serem asseguradas às partes para a tutela de situações que acabam legitimando a própria jurisdição. Do ponto de vista do Autor que pede e do Réu que se defende, o 'devido processo legal' garante a posição dos litigantes perante os órgãos jurisdicionais. Mas, do ponto de vista do Estado, obrigado à prestação jurisdicional e sujeito passivo do direito de ação, esse mesmo conjunto de garantias vai legitimar toda a atividade jurisdicional. Assim, quer quando se considere o processo sob o ângulo da ação movida pelo autor e da defesa oposta pelo réu; quer quando se o considere sob o ângulo da jurisdição exercida pelo Estado, o 'devido processo legal' assegura, de um lado, os direitos públicos subjetivos do Autor e do Réu e, de outro, a própria atividade jurisdicional, legitimando-a." Aspectos 
frentes: (i) determinação das condutas do juiz, de um lado impedindo arbitrariedade na condução do processo, vez que os atos processuais e a maneira como se concatenam estão previstos em lei, e de outro permitindo que aja inclusive de ofício em determinadas situações (como para determinar a produção de prova que se considere indispensável ao deslinde da controvérsia); e (ii) garantia às partes de exercício dos poderes, ônus e faculdades processuais conferidos pela lei. O devido processo legal é, portanto, também, garantia de justiça.

É, assim, forma de proteger o chamado "direito ao processo", que corresponde ao direito de ter acesso às oportunidades de defesa de direitos e interesses em juízo e à prestação jurisdicional adequado. Já em seu aspecto substancial, o devido processo legal representa a garantia de efetividade da tutela jurisdicional ${ }^{49}$, de que oportunamente se tratará em capítulo próprio.

Vê-se, assim, que o devido processo legal abrange garantias fundamentais para o estudo dos agravos: duração razoável do processo, prestação jurisdicional de qualidade, contraditório e ampla defesa.

Os recursos se submetem a elenco taxativo, previsto no art. 496 do Código de Processo Civil, segundo o qual são cabíveis apelação, agravo, embargos infringentes, embargos de declaração, recurso ordinário, recurso especial, recurso extraordinário e embargos de divergência em recurso especial ou extraordinário.

O princípio da taxatividade tem duas principais razões de ser: a primeira corresponde à impossibilidade prática de se deixar indefinidamente aberta a via recursal para a parte prejudicada, o que obstaria o trânsito em julgado e prejudicaria a segurança jurídica perseguida pelo direito processual ${ }^{50}$. Já a segunda se refere à organização estatal, que adota modelo de separação dos poderes: a criação e disciplina dos recursos são de

constitucionais dos juizados de pequenas causas in K. WATANABE (coord.), Juizado especial de pequenas causas (Lei 7.244, de 7 de novembro de 1984), $1^{\mathrm{a}}$ edição, São Paulo, Revista dos Tribunais, 1985, p. 13.

${ }^{49}$ H. THEODORO JR. ensina que "no plano substancial, o processo justo deverá proporcionar a efetividade da tutela àquela a quem corresponda a situação jurídica amparada pelo direito, aplicado à base de critérios valorizados pela equidade concebida, sobretudo à luz das garantias e dos princípios constitucionais" Processo justo cit., p. 12

${ }^{50}$ L. GRECO explica que não se admite "recurso por analogia", uma vez que "o exercício do direito de recorrer não é viável sem a regulamentação legal que defina perante quem o recurso deve ser interposto, em que prazo, quais as decisões que por meio dele podem ser impugnadas, quais as questões cujo exame pode provocar e a que órgão caberá julgá-lo". Princípios de uma teoria geral dos recursos, in Revista eletrônica de direito processual, Rio de Janeiro, 5:2010, p. 26. 
competência do Poder Legislativo, e não podem ser relegadas ao Poder Judiciário, muito menos ao próprio órgão julgador.

O princípio da unirrecorribilidade ${ }^{51}$ é norma de organização do sistema recursal segundo a qual a cada tipo de decisão corresponde apenas um recurso. Embora não esteja expressamente prevista pelo Código de Processo Civil, sua adoção decorre da interpretação sistemática dos dispositivos que tratam, respectivamente, dos tipos de pronunciamentos judiciais, dos recursos existentes, das razões e dos objetivos que se buscam com a interposição dos recursos ${ }^{52}$.

Esse princípio se desdobra em duas ordens de consequências: de um lado, não se pode cogitar a interposição de mais de um tipo de recurso contra a mesma decisão e, de outro, na impossibilidade de conhecer dos recursos interpostos em desacordo com a estipulação do Código ${ }^{53}$, de que se tratará adiante.

No nosso sistema, esse princípio está sujeito a algumas exceções, como a possibilidade de interposição de recurso especial e extraordinário em face do mesmo acórdão $^{54}$. Outrossim, pode-se estar diante de decisão complexa, sendo que para cada capítulo caiba recurso distinto. De todo modo, essas exceções não são suficientes para afastar sua vigência.

Com a modificação do conceito de sentença introduzida pela Lei 11.232/2005, pode-se dizer que houve flexibilização desse princípio, pois quer se

\footnotetext{
${ }^{51}$ Também chamado princípio da singularidade (cf. A. DE AsSIS, Manual cit., p. 83), ou princípio da unidade recursal (cf. J. C. Barbosa Moreira, Comentários cit., pp. 246-247), ou ainda princípio da unicidade (cf. L. G. MARINONI e S. C. ARENHART, Manual do processo de conhecimento, $3^{\mathrm{a}}$ edição, revista e atualizada, São Paulo, Revista dos Tribunais, 2004, p. 547).

52 "Previsto expressamente no código anterior (CPC/39 809 parte final), a subsistência desse princípio no direito vigente decorre da interpretação sistemática que se faz do CPC 496, que enumera os recursos admissíveis pelo código, e da correlação que deve existir entre o CPC 162 e o CPC 504, 513 e 522. De sorte que, ao definir os atos decisórios do juiz, estipulando o cabimento de determinado recurso para cada qual, o CCP adotou o princípio da singularidade.” N. NERY JR., Teoria Geral dos Recursos, v. 1, coleção Recursos no Processo Civil, $6^{\text {a }}$ edição atualizada, ampliada e reformulada, São Paulo, Revista dos Tribunais, 2004, p. 118.

${ }^{53}$ Cf. J. C. Barbosa Moreira, Comentários cit., p. 247.

${ }^{54}$ Explicam L. G. MARINONI e S. C. ARENHART que "tais casos permitem a interposição, contra uma mesma decisão judicial, de mais de uma espécie recursal. Todavia, não se deve esquecer que cada um dos recursos cabíveis contra tais decisões tem função específica, que não se confunde com a finalidade prevista para a outra espécie recursal. Assim, compreendendo que o princípio da unicidade preconiza que, para certa finalidade, contra certo ato judicial deve ser cabível apenas uma modalidade recursal, parece ser correto concluir que o princípio tem plena aceitação no direito brasileiro." Manual do processo de conhecimento, $3^{\mathrm{a}}$ edição revista, atualizada e ampliada, São Paulo, Revista dos Tribunais, 2004, p. 546 - grifo do original.
} 
considere ser sentença parcial ou interlocutória de mérito o pronunciamento judicial que julga parcialmente o objeto de determinada demanda, o recurso para impugná-la será agravo, por solução pragmática.

O princípio do contraditório está na base do próprio conceito de processo judicial, este entendido como procedimento (conjunto de atos concatenados destinados a um fim) exercido em contraditório.

Em um primeiro momento, entendeu-se que seu alcance se cingiria à oportunização de manifestação bilateral perante juiz imparcial. Porém, atualmente, entende-se que a observância do princípio vai além disso, pois mais do que oportunidade de manifestação o contraditório deve implicar a possibilidade de efetivamente influenciar no conteúdo da decisão que será prolatada ${ }^{55}$, inclusive com a proibição de decidir sem que tenha havido amplo debate a respeito dos fundamentos utilizados, como contrapartida do aumento dos poderes do juiz.

E o dever de motivar, decorrência lógica da observância do princípio do contraditório em sua amplitude - vez que pela fundamentação as partes têm condições de verificar se foram efetivamente ouvidas - , é de sumo interesse para o estudo dos recursos, na medida em que é a partir da análise das razões de decidir que se conhece o conteúdo da decisão e se abre a via da sua adequada impugnação. Aliás, mais do que somente às partes, a obrigação de motivar tem também conteúdo político, permitindo-se a aferição concreta da "imparcialidade do juiz e a legalidade e justiça da decisão"

O princípio da ampla defesa possui dois desdobramentos de interesse. Em primeiro lugar, sua observância implica o direito à apresentação de defesa técnica, por advogado ou defensor com capacidade postulatória ${ }^{57}$. Em segundo lugar, o que mais

\footnotetext{
${ }^{55}$ Assim, H. THEODORO JR., para quem "não se pode mais na atualidade acreditar que o contraditório se circunscreva ao dizer e contradizer formal entre as partes, sem que isso gere uma efetiva ressonância (contribuição) para a fundamentação do provimento, ou seja, afastando a ideia de que a participação as partes no processo possa ser meramente fictícia, ou apenas aparente, e mesmo desnecessária no plano substancial". Processo justo cit., p. 3.

${ }^{56}$ A. P. GRINOVER, O conteúdo da garantia do contraditório in Novas tendências do direito processual de acordo com a Constituição de 1988, $2^{\text {a }}$ edição, São Paulo, Forense Universitária, 1990, p. 34.

${ }^{57}$ Cf. ensina N. NERY JR., o princípio tem ainda outros desdobramentos: (i) o direito à autodefesa, no processo penal; (ii) proibição da autoincriminação; (iii) o direito à assistência jurídica integral e gratuita, direito de todos "que comprovarem insuficiência de recursos" (art. 5, LXXIV, da Constituição Federal), que deverá ser prestada pela defensoria pública; e (iv) aplicação também ao processo administrativo. Princípios cit., pp. 244-259.
} 
interessa ao estudo dos recursos, é que a ampla defesa se consubstancia na possibilidade de deduzir alegações, produzir prova a respeito e, sobrevindo decisão desfavorável, interpor recurso para impugná-la.

Evidente que a observância da ampla defesa "com os meios e recursos a ela inerentes" não implica a previsão de recurso para impugnar absolutamente todas as decisões proferidas no curso de qualquer tipo de processo judicial. Deve haver a possibilidade de recorrer das sentenças, mas não é inerente ao conceito de ampla defesa a ampla recorribilidade, inclusive de decisões interlocutórias.

$\mathrm{E}$, tendo em vista que o acórdão proferido em grau recursal substitui a decisão recorrida, evidente que as garantias do contraditório e ampla defesa têm de ser respeitadas também perante o tribunal ad quem, sob pena de se admitir que a decisão em segundo grau seja "pior" do que a decisão atacada ${ }^{58}$.

O fundamento legal do princípio do juiz natural pode ser encontrado nos incisos XXXVII e LIII do art. $5^{\circ}$ da Constituição Federal, que determinam, respectivamente, que "não haverá juízo ou tribunal de exceção" e que "ninguém será processado nem sentenciado senão pela autoridade competente”. Portanto, verifica-se que o princípio possui dois aspectos que se conjugam para compor a garantia: de um lado, proíbe-se a criação de tribunais de caráter excepcional destinados à perseguição política, por exemplo ${ }^{59}$. De outro, prevê-se que o julgador será investido de autoridade pelo Estado, o que somente ocorre após aprovação em concurso público, demonstrada a aptidão pessoal do candidato a juiz para a condução deste mister.

\footnotetext{
${ }^{58}$ Nesse sentido a advertência de L. GRECO: "não basta que o contraditório e a ampla defesa, com todos os seus consectários, tenham sido amplamente assegurados no primeiro grau de jurisdição, porque à segunda instância incumbe proferir uma nova decisão, por novos juízes, com mesmo alcance da decisão de primeiro grau e que a esta substitui. Portanto, as garantias fundamentais devem ser amplamente respeitadas perante esse novo juízo, sem prejuízo do aproveitamento do conteúdo dos atos já praticados no primeiro grau." Principios cit., p. 24.

${ }^{59}$ A esse respeito, P. M. OLIVEIRA explica que a tendência organizacional dos tribunais brasileiros de especialização dos seus órgãos internos não afronta o princípio do juiz natural, na medida em que "deve ser encarada apenas como preferencialidade, e não como exclusividade de um órgão sobre a matéria" e, nesse contexto \#não há de se confundir juízos e tribunais de exceção com juízos e tribunais especiais ou especializados no processamento e julgamento de determinados litígios, conforme sua natureza." Princípios constitucionais do processo civil no ambito recursal in L. FUX, N. NERY JR., T. A. A. WAMBIER (coord.), Processo e Constituição - Estudos em homenagem a José Carlos Barbosa Moreira, $1^{a}$ edição, São Paulo, Revista dos Tribunais, 2006, p. 559.
} 
Especialmente no que diz respeito ao recurso de agravo, cabe analisar se a tendência de aumento dos poderes do relator ofenderia o princípio do juiz natural, que seria o órgão colegiado (câmara ou turma do tribunal). Nesse tocante, é necessário consignar que o julgamento monocrático do recurso de agravo de instrumento pelo relator não ocorre em qualquer situação, de modo que se revela despropositada a crítica sem ressalvas no sentido de que se trataria de usurpação de competência do órgão colegiado. As hipóteses em que o relator pode atuar dessa forma são taxativamente previstas no Código de Processo Civil (art. 557).

Ademais, sempre se prevê a possibilidade de o recurso ser submetido ao órgão colegiado por agravo interno (regimental). Nesse cenário, considerações a respeito da eficiência prática da previsão - que apenas retardaria a análise do recurso pelo colegiado - nenhuma relação possuem com o conteúdo do princípio, que não é violado pelo aumento dos poderes do relator.

Fungibilidade é o princípio que permite o abrandamento da já mencionada unirrecorribilidade, mediante a aceitação de recurso em tese inadequado para impugnar determinada decisão, desde que não haja erro grosseiro ou má-fé da parte. A respeito, Milton SANSEVERINO explica que a simplificação do sistema recursal trazida pelo atual Código de Processo Civil deve ter contribuído para a supressão do conteúdo do art. 819 do Código de 1939, que positivava o princípio ("Salvo a hipótese de má-fé ou erro grosseiro, a parte não será prejudicada pela interposição de um recurso por outro, devendo os autos ser enviados à Câmara ou Turma, a que competir o julgamento") ${ }^{60}$.

No contexto, o erro grosseiro que afasta a aplicação do princípio se caracteriza pela interposição de recurso diverso daquele expressamente previsto em lei, ou daquele cujo cabimento já foi assentado por jurisprudência consolidada. Dito de outra forma, "a oscilação da jurisprudência é fator decisivo para afastar a configuração do erro grosseiro" $"$.

\footnotetext{
${ }^{60}$ Fungibilidade dos recursos, Justitia, São Paulo, 124:1985, p. 71.

${ }^{61}$ T. A. A. WAMBIER, Os agravos no CPC brasileiro, v. 2, coleção Recursos no Processo Civil, $4^{\mathrm{a}}$ edição revista, ampliada e atualizada, São Paulo, Revista dos Tribunais, 2005, p. 160.
} 
Outrossim, embora com alguma resistência da doutrina, a jurisprudência do Superior Tribunal de Justiça adota como requisito para a aplicação do princípio da fungibilidade a interposição no prazo do recurso cabível ${ }^{62}$.

\subsubsection{O PRINCÍPIO DO DUPLO GRAU DE JURISDIÇÃO}

A organização política do Estado estabelece estrutura hierárquica para os órgãos do Poder Judiciário ${ }^{63}$, e esta estruturação é, por vezes, inclusive identificada com a própria essência do direito de recorrer, pois o recurso é o meio pelo qual se instrumentaliza o princípio do duplo grau de jurisdição. Tanto assim que se afirma que seria inerente à própria noção de recurso a submissão de determinada questão a órgão diverso do prolator da decisão recorrida, seja hierarquicamente superior àquele ${ }^{64}$ ou não.

62 "PROCESSUAL CIVIL. RECURSO ESPECIAL. VIA INADEQUADA. ACÓRDÃO QUE MANTEVE INDEFERIMENTO LIMINAR DE INICIAL DE SEGURANÇA ORIGINÁRIA DE TRIBUNAL.

(...) É de se asseverar, ainda, que, para o conhecimento do presente recurso com base na incidência do princípio da fungibilidade recursal, exige-se a cumulação de dois requisitos, a saber: (i) caracterização de dúvida objetiva a respeito da medida impugnativa a ser manejada, o que é suficiente para afastar eventual configuração de erro grosseiro, e (ii) observância do prazo para o protocolo efetivamente cabível. Precedentes.

5. Caracteriza erro grosseiro a interposição de especial por recurso ordinário.

6. Recurso especial não conhecido." (REsp 1283306/MS, Rel. Ministro MAURO CAMPBELL MARQUES, SEGUNDA TURMA, julgado em 01/12/2011).

No mesmo sentido, EDcl no REsp 1066647/SP, Rel. Ministro ADILSON VIEIRA MACABU, QUINTA TURMA, julgado em 03/05/2011; RMS 31.840/SP, Rel. Ministro MAURO CAMPBELL MARQUES, SEGUNDA TURMA, julgado em 04/11/2010; PET no REsp 971.828/DF, Rel. Ministro MAURO CAMPBELL MARQUES, SEGUNDA TURMA, julgado em 18/03/2010, DJe 30/03/2010; RO 77/SC, Rel. Ministra NANCY ANDRIGHI, TERCEIRA TURMA, julgado em 14/04/2009, entre inúmeros outros.

${ }^{63}$ O. N. S. LASPRO explica que "[o] problema restringe-se, assim, não à unidade da jurisdição, nem à jurisdição como atividade distante da administração, mas à competência e à possibilidade que determinados órgãos têm de reexaminar as demandas e rever as decisões de outros julgadores". "Trata-se, na verdade, de mecanismo de há muito enraizado na generalidade dos ordenamentos jurídicos, sendo desconhecidas, atualmente, sociedades civilizadas que o tenham abolido totalmente." E complementa: "Isto não significa, contudo, que se trata de modelo indispensável à garantia do devido processo legal" pois o princípio do duplo grau de jurisdição se refere "muito mais a um problema de natureza política que propriamente jurídico, pois sua aplicação ou restrição depende mais da vontade e forma de concepção da organização de cada Estado." Duplo grau cit., p. 18.

${ }^{64}$ Essa é a opinião de O. A. BAPTISTA DA SILVA, para quem "não se pode esquecer que sua disciplina sistemática, num dado ordenamento jurídico, a ponto de considerar-se o recurso como uma prerrogativa processual, ou mesmo um direito do recorrente, ou até, como certos processualistas o consideram, uma ação, pressupõe a existência de uma certa organização hierárquica e burocrática do poder estatal incumbido de prestar jurisdição." E prossegue: "Daí a ideia, de certo modo implícita no conceito de recurso, de uma autoridade hierarquicamente superior ao magistrado que haja proferido a decisão de que se recorre, ou seja, da existência do duplo grau de jurisdição." Curso cit., p. 407.

Em sentido contrário, F. C. PONTES DE MIRANDA, Comentários cit., tomo VII, p. 2. 
Essa é a razão pela qual se optou por estudar separadamente o princípio do duplo grau de jurisdição, delineando seu alcance no ordenamento brasileiro, bem como apontando vozes que opinam pela sua "racionalização".

O princípio do duplo grau de jurisdição - que se relaciona com a competência (medida de jurisdição) de determinado órgão jurisdicional para reexaminar demandas, uma vez preenchidos os requisitos legalmente impostos para tanto - se consubstancia na possibilidade de existir reexame da decisão válida e completa proferida em primeiro grau de jurisdição, de tal modo que a segunda decisão substitua a primeira ${ }^{65}$.

Sua existência se explica pela circunstância de que, na conformação do sistema processual, como já se mencionou, dois princípios potencialmente opostos devem ser conciliados: certeza e justiça ${ }^{66}$. Assim sendo, permitir a revisão das decisões judiciais indefinidamente possivelmente atenderia ao segundo, mas o processo deve conviver com a necessidade de limitação temporal da sua duração, sob pena de sujeitar os jurisdicionados a perene situação de indefinição ${ }^{67}$.

Observa-se, portanto, adoção de solução de compromisso em praticamente ${ }^{68}$ todos os ordenamentos modernos, pela regulamentação da possibilidade limitada de

\footnotetext{
${ }^{65}$ Essa é a lição de G. CHIOVENDA: "El principio admitido en nuestro derecho del doble grado de jurisdicción consiste en que todo litigio excepto en los casos expresamente previstos por la ley, debe poder pasar para su pleno conocimiento por dos tribunales sucesivamente". Principios de Derecho Procesal Civil, tomo II, $1^{\text {a }}$ edição, trad. José Casais y Santaló, Madri, Reus, 1925, p. 488 - grifo do original. No mesmo sentido, O. N. S. LASPRO, Duplo grau de jurisdição no direito processual civil, v. 33, coleção Estudos de Direito de Processo Enrico Tullio Liebman, São Paulo, Revista dos Tribunais, 1995, p. 27.

66 "Não se pode olvidar, neste particular, a existência de dois postulados que, em princípio, são opostos: o da segurança jurídica, exigindo um lapso temporal razoável para a tramitação do processo, e o da efetividade do mesmo, reclamando que o momento da decisão final não se procrastine mais do que o necessário.” J. R. CRUZ E TUCCI, Garantia da prestação jurisdicional sem dilações indevidas como corolário do devido processo legal in J. R. CRUZ E TUCCI, R. L. TUCCI, Devido processo legal e tutela jurisdicional, $1^{\mathrm{a}}$ edição, São Paulo, Revista dos Tribunais, 1993, p. 101.

${ }^{67}$ Cf. relata J. C. BARBosa MoreirA, "[d]esde tempos remotos têm-se preocupado as legislações em criar expedientes para a correção dos possíveis erros contidos nas decisões judiciais. À conveniência da rápida composição dos litígios, para o pronto restabelecimento da ordem social, contrapõe-se o anseio de garantir, na medida do possível, a conformidade da solução ao direito. Entre essas duas solicitações, até certo ponto antagônicas, procuram os ordenamentos uma via média que não sacrifique, além do limite razoável, a segurança à justiça, ou esta àquela. Fazer inimpugnáveis quaisquer decisões, desde que proferidas, atenderia ao primeiro interesse, mas com insuportável detrimento do segundo; multiplicar ad infinitum os meios de impugnação produziria efeito diametralmente oposto e igualmente danoso." Comentários cit., p. 227.

${ }^{68}$ Noticia E. D. MonIZ DE ARAGÃo que o Cantão de Neuchâtel, na Turquia, desconhece o recurso de apelação. Demasiados recursos? cit., pp. 178-179. No entanto, o processualista ressalta que se trata de “exceção a confirmar a regra, pois não sei de outro país, integrante de nossa cultura, onde não exista recurso de apelação, ou similar, a fim de permitir a revisão - em maior ou menor grau de amplitude - das causas por uma instância superior”. Demasiados recursos cit., p. 179.
} 
recorrer, que propicia a revisão dos pronunciamentos jurisdicionais, mas impede que o processo se prolongue infinitamente ${ }^{69}$.

Se, de um lado, a demora na entrega da resposta jurisdicional pode ter efeitos tão deletérios quanto os da própria violação ao direito material, de outro, convém lembrar que, possuindo as decisões judiciais aptidão para fazerem coisa julgada (assumindo caráter de imutabilidade), a preocupação com a qualidade não pode ser deixada de lado. Nesse contexto, uma resposta mais veloz, que privilegiasse a celeridade em detrimento do conteúdo, não poderia ser considerada "melhor" ou mais satisfatória do que aquela que, embora tardasse mais, estivesse menos sujeita a erro por ter sido submetida a controle interno mediante o exercício do duplo grau de jurisdição ${ }^{70}$.

Com a previsão de um procedimento mais completo e aprofundado para se chegar à decisão final - pela possibilidade de duplo julgamento das questões postas à apreciação do Poder Judiciário - pretende-se obter pronunciamento judicial mais aderente à realidade e que também observe a adequada aplicação da lei ao caso concreto, propiciando a aplicação ou a reafirmação de outras garantias processuais já mencionadas, como o contraditório e a ampla defesa ${ }^{71}$. Em complemento, atualmente, não há relação de

\footnotetext{
${ }^{69}$ É o que observa A. P. GRINOVER: “[n]a realidade, a tendência é no sentido de conservar-se o duplo grau de jurisdição, em benefício do princípio da justiça; mas se nota, paralelamente, a preocupação em limitar-se o número de recursos, a fim de resguardar também o princípio da certeza e o princípio da brevidade." Os princípios cit., p. 137.

${ }^{70}$ Nesse tocante, pertinentes os questionamentos de E. ALLORIO: "Quel genere di giustizia che approdi a un risultato - la cosa giudicata - conseguito con la sola preoccupazione della sollecitudine? Del fabbricate una certezza veloce, senza riguardo all'effettiva corrispondenza tra lo stato del diritto precedente al processo e il contenuto della disciplina giudiziale, di quel regolamento che dovrebbe riflettere la situazione anteriore di diritto sostanziale, ma che tanto meno probabilmente la rispecchia, quanto più precipitoso è l'iter per arrivare al giudicato? Oppure una 'giustizia' conseguita attraverso un procedimento più lento sì, ma meno probabilmente esposto all'errore; e ciò soprattutto in virtù di controlli interni di quel procedimento, tra i quali il doppio grado di giudizio non costituisce certamente la più insignificante delle garanzie?" Sul doppio grado cit., p. 1786 - grifos do original.

${ }^{71}$ Nesse sentido, certo que tratando do recurso de "appello" do direito italiano, L. MORTARA: "Per dare un senso più concreto a queste nostre deduzioni, ci porremo innanzi senz'altro la domanda: malgrado le osservazioni sin qui fatte, l'appello è esso una garanzia giudiziaria? Non esitiamo a rispondere affermativamente, e secondo la storia, e secondo la scienza (...). Ma se la perfezione delle leggi, l'altezza della civiltà o per parlar di minori cause, l'introduzione di mezzi di reclamo più conferenti allo spirito e ai bisogni di un'epoca e d'una popolazione, rendessero inutile e facessero cadere in disuso l'appellazione, non sarebbe certo un motivo codesto per supporne minacciata o lesa la giustizia nella pienezza della sua azione; conciossiaché, ripetiamolo pure, non v'è nell'appello alcun estremo sostanziale di perpetua ed immutabile necessità". Appello civile in Digesto Italiano, v. 3, parte 2 ${ }^{\mathrm{a}}$, Turim, Unione Tipografico, 1890, p. 453.
} 
dependência entre os graus de jurisdição, tampouco se consubstancia o recurso em reclamação contra a pessoa do julgador, como já ocorreu em épocas passadas ${ }^{72}$.

Porém, embora esteja profundamente arraigado na nossa cultura jurídica, ao menos em teoria, sua previsão não é essencial para compor o devido processo legal ${ }^{73}-$ que $^{2}$ abrange cláusula de controle judicial das decisões proferidas, mas não necessariamente de submissão do inconformismo a dois graus de jurisdição ${ }^{74}$.

Nesse cenário, resta claro que a regulamentação do princípio do duplo grau de jurisdição é matéria de escolha legislativa, que se rege tanto por razões de ordem técnica quanto política ${ }^{75}$. Desse modo, são inúmeras em tese as possibilidades ${ }^{76}$, podendose, por exemplo, restringir o reexame do feito ao estabelecido pelo juízo de primeiro grau, proibir a dedução de novos fatos e a produção de novas provas, ou então, no outro extremo, permitir o reexame completo da demanda ${ }^{77}$.

${ }^{72}$ Cf. G. Chiovenda, Principios de Derecho Procesal Civil, tomo I, $1^{\text {a }}$ edição, trad. José Casais y Santaló, Madri, Reus, 1922, pp. 468-469.

${ }^{73}$ Em sentido contrário, A. P. GRINOVER, para quem "um sistema de juízo único fere o devido processo legal, que é garantia inerente às instituições político-constitucionais de qualquer regime democrático". Um enfoque cit., p. 66.

${ }^{74}$ Defendendo a possibilidade em tese de existirem demandas que não estejam submetidas a recurso, J. G. GONÇALVES FILHO: "perfeitamente possível dentro do nosso sistema processual, que as causas estejam submetidas a julgamento de um único órgão jurisdicional, sem possibilidade de recurso, porque essa escolha legislativa está de conformidade com o princípio da eficiência quanto aos aspectos de celeridade e de segurança (como estabilidade) da decisão." O princípio constitucional da eficiência no Processo Civil, tese (doutorado em Direito Processual Civil), Faculdade de Direito - Universidade de São Paulo, São Paulo, 2010, p. 278.

${ }^{75}$ É o que explica F. C. PONTES DE MIRANDA: "Só existe o princípio da recorribilidade de todas as resoluções que constituam entrega definitiva da prestação jurisdicional, terminando, regularmente, a relação jurídica processual, ou desfazimento da relação jurídica processual sem a entrega da prestação jurisdicional, ou que levem a consequências irremovíveis quanto ao conteúdo daquela prestação ou a esse desfazimento. É o princípio da recorribilidade das resoluções judiciais relevantes. O problema de técnica legislativa é, então, o de se discriminar o que é relevante e o que é irrelevante". Comentários cit., p. 2 grifos do original.

${ }^{76}$ A esse respeito, M. MigliazZA, analisando os contornos do princípio do duplo grau de jurisdição no direito da comunidade europeia, assinala que "Il problema delle impugnazioni si configura dunque in modo diverso in relazione ai tipi di diritti, fondamentali e non, che fanno capo ai soggetti legittimati a proporle negli ordinamenti statali e comunitario, ma simile quanto ad alcune delle ragioni che lo spiegano. Esigenze differenti di tutela sono infatti riferibili agli individui rispetto agli Stati o alle istituzioni comunitarie e si devono manifestare in modo ugualmente garantista negli ordinamenti nazionali e comunitario per i soggetti privati: il fine ultimo è però lo stesso, quello di realizzare un processo 'giusto0 e quindi razzionalizzato in modo tale da soddisfare le esigenze proprie anche ai soggetti-autorità, caratteristici dell'ordinamento comunitario." Il doppio grado di giurisdizione nel diritto delle Comunità europee, $1^{\mathrm{a}}$ edição, Milão, Franco Angeli, 1993, p. 30 .

${ }^{77}$ E. RICCI observa, a partir da análise do duplo grau de jurisdição no direito positivo italiano, austríaco e alemão, que "[n]el complesso, la tendenza al superamento del doppio grado ha dunque manifestazione massicce: e se qualche cosa appare come veramente irrinunciabile, ciò non è tanto il grado doppio quanto il 
Passa-se, então, a detalhar o alcance do princípio do duplo grau de jurisdição no ordenamento brasileiro, de modo a possibilitar a adequada compreensão do recurso de agravo. No sistema pátrio, via de regra, qualquer vício da decisão atacada é recorrível, observados os requisitos de admissibilidade de cada tipo de recurso. Assim, tanto eventuais erros de natureza processual (errores in procedendo) quanto erros de julgamento (errores in judicando) podem ser impugnados, da mesma forma que as matérias de direito e de fato $^{78}$ que tenham sido objeto da decisão combatida, permitindo sua devolução ao órgão $a d$ quem $^{79}$.

O recurso que instrumentaliza o duplo grau de maneira mais explícita é a apelação, posto que devolve ao grau superior a competência para conhecer de toda a matéria impugnada em relação à qual o recorrente tenha sucumbido. No nosso sistema processual, contudo, as decisões interlocutórias estão sujeitas à preclusão, de modo que, se não impugnadas no prazo concedido por lei, não poderão ser reexaminadas quando da interposição daquele recurso, como adiante se explorará. Assim, o agravo exerce função complementar à da apelação no que diz respeito ao duplo grau de jurisdição ${ }^{80}$.

A observância do duplo grau no sistema processual brasileiro se dá com a submissão do inconformismo a um reexame perante os órgãos de recurso ainda em jurisdição ordinária. É o que decorre dos aspectos positivo e negativo deste princípio: pelo aspecto positivo, o recurso é cabível em face de decisão em primeiro grau de jurisdição em consequência apenas da sucumbência, e deve submeter ao tribunal a análise do próprio objeto da decisão impugnada ${ }^{81}$.

grado unico. Un grado unico è realizzato a rigor di termini, tramite l'appello nei casi passati in rassegna supra, da 3.4.1 a 3.5.4.; ed un grado unico risulta nella sostanza quello composto dal giudizio di prime cure e dal giudizio di appello, quando in appello sono state introdotte nuove eccezioni e nuove prove". Doppio grado di diurisdizione (principio del), verbete in Enciclopedia Giuridica, v. 12, Roma, Istituto della Enciclopedia Italiana, Treccani, 1989, p. 7.

${ }^{78}$ Contudo, somente podem ser alegados novos fatos se o recorrente demonstrar que deixou de apresentá-los em primeiro grau de jurisdição por motivo de força maior, a teor do art. 517 do Código de Processo Civil: "As questões de fato, não propostas no juízo inferior, poderão ser suscitadas na apelação, se a parte provar que deixou de fazê-lo por motivo de força maior."

${ }^{79}$ Cf. A. P. Grinover, Um enfoque cit., p. 67.

${ }^{80}$ Nesse sentido, A. P. Grinover, Um enfoque cit., pp. 67-68, e O. N. S. LASPRo, Duplo grau cit., pp. 161162.

${ }^{81}$ Cf. E. RicCI, Doppio grado cit., p. 2. 
Então, a decisão ou acórdão proferido após a análise do recurso substitui a decisão recorrida, havendo duplo julgamento e não apenas duplo exame ${ }^{82}$. Uma vez exercido o direito de recorrer, em razão do aspecto negativo do mesmo princípio, o sistema processual se satisfaz com a segunda decisão ${ }^{83}$.

Essa constatação reforça que, em consonância com o já afirmado, os recursos dirigidos aos chamados tribunais de sobreposição (Superior Tribunal de Justiça, Supremo Tribunal Federal, Tribunal Superior do Trabalho, Tribunal Superior Eleitoral) se justificam por outras razões. Embora, como já se mencionou, o princípio do duplo grau possa assumir diferentes configurações - o que permitiria que fosse estruturado para permitir apenas o reexame da legalidade da decisão -, não é o que ocorre no cenário atual brasileiro $^{84}$.

\subsubsection{BREVEMENTE, DO DEBATE TEÓRICO DESENVOLVIDO NA ITÁliA A RESPEITO DA RACIONALIZAÇ̃̃o DO DUPLO GRAU DE JURISDIÇÃO}

Como se procurou demonstrar, praticamente todos os ordenamentos jurídicos contemporâneos adotam o princípio do duplo grau de jurisdição. No entanto, isso não significa que o princípio seja unanimidade entre os teóricos do processo. Com efeito, muito já se debateu a respeito da conveniência de se manter no sistema processual a referida garantia.

\footnotetext{
${ }^{82}$ É o que ensina L. MORTARA: "L'autorità della cosa giudicata si può verificare anche senza bisogno del secondo esame; ciò significa tropo manifestamente, per rimanere incerto in alcuna guisa, che un primo $\mathrm{e}$ perfetto giudizio si è verificato nel contradittorio di prima istanza. E l'appello essendo in sè stesso una lotta che s'istaura dopo la sentenza dei giudici inferiori ed intorno ad essa, fra i due contendente, interessati l'uno a distruggerla l'altro a conservarla, è quindi in realtà un vero secondo giudizio." Appello cit., p. 457.

83 "Il modello del doppio grado, inoltre, se da un lato non si accontenta della prima statuzione sul diritto controverso, dall'altro si accontenta della seconda: onde il paradigma è contrario a che quest'ultima sia a sua volta impugnabile con un mezzo come quello appena descritto sostitutivo, devolutivo, fondato sull'unico presupposto della soccombenza).” E. RiCCI, Doppio grado cit., p. 2.

${ }^{84}$ Nesse sentido, M. MigliazzA assinala que seria possível “ipotizzare un contenuto nuovo del principio del doppio grado, privilegiando il rimedio più recente della Cassazione a quello dell'appello, e costruendo un concetto di impugnazione che consiste in un controllo di mera legittimità solo per funzione." E prossegue para concluir que "[1]'impugnazione comunitaria è maggiormente assimilabile quanto ai motivi e alla struttura al ricorso in Cassazione che all'appello, ed avvalora l'ipotesi che la nozione stessa di impugnazione vada rimeditata, per realizzare nel modo più garantistico e razionale il principio del doppio grado che è comunque presente in tutti i moderni ordinamenti giudiziari” Il doppio grado cit., pp. 30-31.
} 
MAURO CAPPELLETTI argumentou, neste tocante, que a manutenção do duplo grau nos moldes em que previsto na Itália (em que, tal como no Brasil, na apelação se concede a oportunidade de um novo julgamento a respeito dos fatos) implica em profunda desvalorização do primeiro grau de jurisdição, e, paralelamente, em "glorificação" do grau de recurso ${ }^{85}$.

Isso se deveria a dois fatores primordiais: em primeiro lugar, em razão do efeito suspensivo normalmente concedido ao recurso de apelação, após a prolação da sentença, o primeiro grau de jurisdição é como que uma longa fase preparatória do julgamento. Em segundo lugar, o duplo grau de jurisdição não é, na opinião do processualista, garantia constitucional fundamental e inderrogável, mas tende-se a vê-lo quase como tal ${ }^{86}$.

Para ele, o sistema recursal italiano poderia ser racionalizado mediante a substituição do "appello" pelo "ricorso per cassazione" (de função semelhante à dos nossos recursos para Tribunais Superiores), regulando-se um grau único de juízo sobre os fatos, com recurso tratando apenas de eventual erro na aplicação do direito ${ }^{87}$.

ALESSANDRO PIZZORUSSO compartilha desse entendimento, tendo afirmado que as justificativas teóricas empregadas para a manutenção do recurso de appello no sistema italiano - como a autoridade política prevalecente do segundo grau, ou a maior sapiência do órgão recursal em comparação com o primeiro grau, ou ainda, e

${ }^{85}$ Tratando dos defeitos do procedimento que deveriam ser atacados em reforma que se propunha à época, M. CAPPELLETTI assim se manifestou: "Il primo essenziale difetto (...) è la profonda svalutazione del giudizio di primo grado, con la connessa glorificazione, se così posso dire, dei giudizi di gravame. Da un lato, la sentenza di primo grado non è, normalmente, dotata di forza esecutiva. Dall'altro lato, l'appello è un giudizio de novo, esteso a fatti nuovi, a nuove eccezioni e a prove nuove (...). Il resultato è che, in primo grado, la causa non è né vinta né persa: il primo grado di giudizio è solo una lunga fase di attesa, una sorta di annosa e spesso estenuante e penosa anticamera per giungere alfine alla fase di appello; e quest'ultima è il solo e vero giudizio, almeno per la parte che economicamente se lo può concedere." Parere iconoclastico sulla riforma del processo civile italiano in Giustizia e società, v. 11, coleção Diritto e cultura moderna, $1^{\mathrm{a}}$ reimpressão da $1^{\mathrm{a}}$ edição, Milão, Edizioni di Comunità, 1977, p. 116 - grifos do original.

86 "Naturalmente, c'è ancora chi, in buona o in mala fede, pensa all'appello e al 'doppio grado di giurisdizione' come ad una importante garanzia processuale, magari una garanzia di libertà, addirittura qualcosa di assoluto e insopprimibile. Ė indubbio che questa concezione non regge ad una critica seria e spregiudicata. (...) nessun ordinamento, né in Italia né in qualsiasi altro paese - tanto meno in Francia, dove l'idea del 'double degré de jurisdiction' pur sembra essere particolarmente radicata - considera il doppio grado di giurisdizione come una garanzia costituzionale, protetta cioè come una garanzia fondamentale e inderogabile." Parere iconoclastico cit., p. 117 - grifos do original.

87 "L'eccesso di garanzie si ritorce contro il sistema. Assai meglio è cercare di avere, come nei sistemi anglosassoni e in tanti altri, un accurato giudizio di primo grado, finale per ciò che concerne le questioni di fatto, e aperto soltanto ad una impugnazione per errore di diritto sostanziale e processuale, anziché ad un vero e proprio riesame del merito della causa." Parere iconoclastico cit., pp. 117-118 - grifos do original. 
principalmente, a circunstância de ser o apelo uma questão de justiça - são, no mais das vezes, pouco contundentes ${ }^{88}$. Quanto a este último, argumenta PIZzorusso que não há nenhuma garantia de que a segunda decisão venha a ser mais justa que a primeira ${ }^{89}$.

EDOARDO RiCCI também ponderou que a comparação entre o tempo despendido para o julgamento do recurso, de um lado, e a frequência com a qual as decisões são reformadas em grau de recurso, de outro, permitiria concluir que o duplo grau somente em raras situações atua verdadeiramente como um remédio contra o erro ${ }^{90}$.

Entretanto, a despeito das respeitáveis críticas, o princípio tem sido observado em praticamente todos os ordenamentos jurídicos modernos, e nem mesmo a modificação do regime de impugnação das decisões interlocutórias que se pretende implementar pelo novo Código de Processo Civil parece alterar substancialmente esse quadro. Isso porque, na linha do que já se afirmou, a regulamentação dessa garantia pode ser amoldada para melhor se adaptar a circunstâncias externas ao processo, ou de modo a buscar maior celeridade, mas não se está realmente propondo a sua eliminação, nem para as decisões interlocutórias, muito menos para as sentenças.

\footnotetext{
88 "Se si riesaminano infatti le ragioni che correntemente vengono portate per giustificarne la conservazione da parte del nostro diritto positivo, evidente appare la debolezza della maggior parte di esse. Universalmente respinta appare innanzi tutto, fra gli studiosi moderni, la giustificazione che parrebbe invece stare alla basse dell'origine e dell'evoluzione storica dell'istituto, cioè quella fondata sull'autorità politicamente prevalente del soggetto che giudica sull'appello rispetto a quella del soggetto che ha pronunciato la sentenza appellata. Debole appare altresì la giustificazione fondata sull'ipotetica maggiore saggezza, preparazione o cultura giuridica dei giudici di appello, cui facilmente si è replicato - già più di un secolo fa - che se così fosse basterebbe, per risolvere ogni problema, affidare a questi giudici il compito di decidere le cause fin dal primo grado." Doppio grado di giurisdizione e principi costituzionali, Rivista di diritto processuale, 1:1978, p. 44.

89 “ (...) l'argomento che fonda la giustificazione del doppio grado sulle esigenze di giustizia è stato da tempo efficacemente ribattuto: se infatti è indiscutibile che una ripetizione del giudizio per un numero più alto possibile di volte offre maggiori possibilità di individuare la soluzione più giusta da dare al caso, è evidente però che nulla dimostra che più giusta sia proprio la soluzione che viene trovata per ultima. Come già rilevò Ulpiano, la riforma della sentenza può portare tanto alla sostituzione di un cattivo giudizio con un migliore quanto al risultato inverso.” Doppio grado cit., p. 45.

90 “(...) il sistema del doppio grado - per il fatto di procrastinare nel tempo la soluzione del caso concreto ha l'ulteriore difetto di rendere più lenta l'amministrazione della giustizia nel caso singolo: e giustizia più lenta vuol dire giustizia fornita di un minor grado di effetività e quindi di minor interesse per chi deve fruirne. Si pensa normalmente che questo sia un sacrificio da compiere sull'altare del doppio grado, essendo la maggior lentezza la contropartita di una maggior garanzia di decisione giusta; e già una simile opinione meriterebbe forse qualche notazione dubitativa. Occorrerebbe infatti procedere ad un più approfondito studio da un lato dell'entità del ritardo che nell'esperienza il doppio grado ha comportato e comporta, dall'altro della frequenza con la quale - essendo il primo verdetto sovvertito dal secondo - il secondo grado può essere effettivamente considerato (in ipotesi) utile rimedi di errori. L'eccesiva durata del processo e la frequenza, con la quale la fase d'appello si conclude con la conferma della sentenza impugnata, potrebbero ad esempio anche indurre a ritenere che il costo pagato sia eccesivo rispetto all'utilità del risultato raggiunto". Doppio grado cit., p. 8.
} 


\subsection{TIPOS DE DECISÕES RECORRÍVEIS E RECURSOS CABÍVEIS}

O Código de Processo Civil (art. 162) prevê três tipos de pronunciamentos do juiz singular em primeiro grau de jurisdição: despachos, decisões interlocutórias e sentenças. Por não possuírem conteúdo decisório propriamente, via de regra ${ }^{91}$ os despachos não estão sujeitos a serem desafiados por recurso ${ }^{92}$.

Conforme já se mencionou, nosso sistema adota o princípio da unirrecorribilidade, pelo qual, via de regra, contra determinada decisão, para uma finalidade específica, é cabível apenas um tipo de recurso. Segundo esse sistema, é adequado o recurso de agravo para atacar decisão interlocutória; e a apelação desafia as sentenças.

Em sua redação original, o Código de Processo Civil previa que seria sentença o ato que pusesse fim ao processo $^{93}$, enquanto decisão interlocutória era o pronunciamento por meio do qual o juiz decidia questão incidente ${ }^{94}$. Segundo este critério

${ }^{91}$ Diz-se "via de regra" em atenção "à circunstância de que nem sempre o Código foi fiel aos seus conceitos, não raro denominando verdadeiras decisões de despachos", destacada, entre outros, por A. DALL'AGNOL. Comentários ao Código de Processo Civil, v. 2, $2^{\text {a }}$ edição revista, atualizada e ampliada, São Paulo, Revista dos Tribunais, 2007, p. 277.

${ }^{92}$ Assim ensina H. THEODORO JR.: "[a]s sentenças e decisões são sempre recorríveis, qualquer que seja o valor da causa (arts. 513 e 532). Dos despachos, isto é, dos atos judiciais que apenas impulsionam a marcha processual, sem prejudicar ou favorecer qualquer das partes, não cabe recurso algum (art. 504)." Curso de Direito Processual Civil, v. 1, 50 a edição comemorativa, Rio de Janeiro, Forense, 2009, p. 557, grifos do original. Em complemento, T. A. A. WAMBIER explica que somente são irrecorríveis os despachos que não sejam capazes de gerar prejuízo à parte. "Essa afirmação diz respeito tanto àqueles despachos proferidos pelo serventuário, confirmados pelo juiz, quanto àqueles que são originariamente proferidos pelo magistrado. Para nós não pode ser tida como absoluta a regra da irrecorribilidade." Os agravos cit., p. 128.

${ }^{93}$ Cf. J. C. BARbosa Moreira: "feita abstração de deslizes, o conceito de sentença baseava-se em critério puramente topológico, não substancial. O que interessava não era o conteúdo do ato, mas a pura e simples posição por ele ocupada no itinerário do feito. Na arquitetura característica do Código, a sentença assinalava o ponto final de um processo. À vista da cisão formalmente estabelecida entre o processo de conhecimento e o de execução, nos casos em que este havia de seguir-se àquele, bem se compreende a significação da parte final do parágrafo $1^{\circ}$ do art. 162: a cláusula 'decidindo ou não o mérito da causa' referia-se precipuamente às duas modalidades distintas de julgamento no instante final da atividade cognitiva do órgão judicial." A nova definição de sentença (Lei $n^{\circ}$ 11.232), Revista Dialética de Direito Processual, 39:2006.

94 “A tormentosa questão do cabimento dos recursos deita suas raízes na tríplice divisão dos atos decisórios do juiz: $a$ ) sentença; $b$ ) decisão interlocutória; $c$ ) despachos; cuja definição o legislador teve de enfrentar na reforma de base do sistema processual." J. Milhomens, Dos recursos cíveis, $1^{\text {a }}$ edição, Rio de Janeiro, Forense, 1991, p. 239. No mesmo sentido, N. A. M. SAntos in A. C. Marcato (coord.), Código de Processo Civil interpretado, $3^{\text {a }}$ edição, São Paulo, Atlas, 2007, p. 448. 
- que era alvo de críticas doutrinárias ${ }^{95}$-, portanto, não era em princípio o conteúdo da decisão que definia o conceito de sentença ${ }^{96}$.

Esse quadro, contudo, foi modificado pela Lei $\mathrm{n}^{\mathrm{o}} 11.232 / 2005$, que alterou o modo de execução da sentença condenatória de dar quantia certa - a qual passou a se dar nos mesmos autos do processo de conhecimento, eliminando a necessidade de propositura de ação de execução. Assim, instituiu-se o que se convencionou chamar processo sincrético, na linha da tendência iniciada em 1994 relativamente às execuções de obrigação de fazer e não fazer.

Para tanto, a Lei Processual passou a prever que a sentença é o ato que “implica alguma das consequências" previstas nos arts. 267 ou 269 do Código de Processo Civil $^{97}$. Com isso, o conteúdo da decisão ${ }^{98}$ passou a ser o traço que permite caracterizar determinado pronunciamento judicial como sentença ${ }^{99}$, diferenciando-o de decisões

95 "Se por um lado, ninguém é capaz de negar que o conceito de sentença oferecido pela redação anterior não
era muito claro ('ato pelo qual o juiz põe termo ao processo, decidindo ou não o mérito da causa'); por outro,
ao longo da interpretação de mais de trinta anos do Código de Processo Civil de 1973, doutrina e
jurisprudência já haviam conseguido elucidar inúmeras situações duvidosas." P. H. S. LuCON, Sentença e
liquidação no CPC (Lei 11.232/2005) in L. FuX, N. NERY JR., T. A. A. WAMBIER (coords.), Processo e
Constituição - Estudos em homenagem ao professor José Carlos Barbosa Moreira, São Paulo, Revista dos
Tribunais, 2006, p. 910 .

${ }^{96}$ Antes mesmo da referida reforma, J. MiLhomens já advertia que "Sendo os nomes apenas um sinal distintivo das coisas, e como as coisas de ordinário se apresentam em múltiplas variedades, temos que essas denominações (sentença, decisão, despacho), embora úteis aos fins a que se destinam, sujeitam-se a variação, subdivisão, subclassificação." Dos recursos cit., p. 240. No mesmo sentido, T. A. A. WAMBIER defendia que "eventual definição legal de sentença deve ater-se ao seu conteúdo." Os agravos cit., p. 111 - grifo do original.

${ }^{97}$ A nova redação também não escapou às críticas da doutrina. J. C. BARBOSA MOREIRA condena a utilização do verbo "implicar" no art. $162, \S 1^{\circ}$, afirmando que a sentença "não 'dá a entender', não 'pressupõe', nem 'traz como consequência' ou 'importa' as hipóteses arroladas nos arts. 267 e 269." A nova definição cit., p. 83. Substancialmente de acordo A. DE Assis, Manual cit., p. 372.

${ }^{98}$ Discordam dessa afirmação G. D. MiRAndA e P. M PIZzol, para quem "o legislador distinguiu as duas espécies de decisões pelo critério topográfico (a sentença põe fỉm ao procedimento em primeiro grau de jurisdição e a decisão interlocutória é proferida no curso do procedimento) e não apenas pelo critério do conteúdo", vez que, segundo seu raciocínio, "como não foi alterado o conceito de decisão interlocutória, tampouco o regime jurídico dos recursos de apelação e agravo, uma interpretação sistemática do CPC conduz à conclusão de que o critério topológico não foi afastado, tendo sido apenas acrescentado outro - o do conteúdo". Recursos no processo civil, 6 a edição, São Paulo, Atlas, 2009, pp. 3-4.

Convém ressaltar que, para H. V. M. SICA, a abrangência das decisões interlocutórias foi reflexamente modificada pela alteração da Lei $\mathrm{n}^{\circ}$ 11.232/2005: "dependendo se a matéria incidental atinente à aplicação de hipótese do art. 267 é acolhida ou rejeitada, a decisão terá a condição de sentença [ou] de decisão interlocutória, respectivamente." "Destarte, a alteração do conceito de sentença acaba, de certa forma, reduzindo o campo das decisões interlocutórias. A elas se reservam todas as questões necessárias a 'viabilizar a marcha do processo', a fim de 'remover os obstáculos opostos a essa meta'." Preclusão processual civil, $2^{\mathrm{a}}$ edição, São Paulo, Atlas, 2008, p. 198 - grifos do original.

99 “O critério discretivo, reitere-se, já não tomará por base a posição do ato no itinerário do processo: terá de levar em conta elemento relativo ao conteúdo. Embora ambas - a sentença e a decisão interlocutória - se 
interlocutórias $^{100}$. Entretanto, a nova classificação também não deixa de suscitar dúvidas, eis que, como bem apontou HeITOR SICA, o pronunciamento que extinguir o processo com ou sem resolução de mérito também estará resolvendo questão incidente. Por isso, propõe ele a identificação das decisões interlocutórias por exclusão, tratando-se dos pronunciamentos judiciais providos de conteúdo decisório que não acarretem as consequências previstas nos arts. 267 e 269 do Código de Processo Civil ${ }^{101}$.

Embora seja possível supor que a alteração do conceito legal de sentença não tenha objetivado gerar modificação na definição do recurso cabível contra cada tipo de pronunciamento judicial, impossível deixar de observar que repercutiu neste campo, suscitando dúvidas. Conquanto se trate de tema interessante e profícuo, por fugir ao escopo deste trabalho, dele não se tratará mais do que tangencialmente.

Para os fins deste estudo, é necessário recordar que, no sistema original do Código de Processo Civil, vigia sem maiores questionamentos o princípio da unidade do julgamento, segundo o qual a matéria de mérito deduzida na demanda seria enfrentada (se reunisse as condições para tanto), em sentença ${ }^{102}$.

situem 'no curso do processo', uma se distinguirá da outra em razão da matéria: a decisão interlocutória dirá respeito a mera 'questão incidente'. Desta noção devem logicamente excluir-se as impropriamente ditas 'situações' do art. 269, para as quais o juízo proferirá sentença. Em tal perspectiva, a decisão interlocutória continuará a ser impugnável mediante agravo, e a sentença mediante apelação.” O raciocínio é semelhante para as situações em que o processo é extinto sem resolução do mérito (art. 267): "[n]o caput desse dispositivo, consoante se notou, subsiste a referência à extinção do processo - o que gera dissonância com a nova sistemática, à vista da necessidade da prática de atos executivos subseqüentes, destinados a dar efetividade a condenações acessórias. Mas, seja como for, o ato judicial de que cuida o texto em foco merecerá a denominação de sentença.” J. C. BARBOSA MOREIRA, A nova definição cit., p. 85.

${ }^{100}$ Após a modificação introduzida pela Lei $n^{0} 11.232 / 2005$, assim se manifestou T. A. A. WAMBIER: "Cremos, portanto, ser esta a nota marcante das sentenças, ou seja, é o seu conteúdo, preestabelecido por lei de forma expressa e taxativa, que as distingue dos demais pronunciamentos do juiz." O conceito de sentença no CPC reformado, in A. F. FABRíCIO, Meios de impugnação ao julgado civil-estudos em homenagem José Carlos Barbosa Moreira, Rio de Janeiro, 2007, p. 533.

101 “[P]arece-nos que o ponto-chave para a compreensão dessa nova sistemática esteja em ignorar a idéia de 'solução de questão incidente' presente no texto do artigo $162, \S 2^{\circ}$, do $\mathrm{CPC}$, que se defina como decisão interlocutória por exclusão, isto é, será todo provimento que, tendo cunho decisório, não implique situação dos artigos 267 e 269. Com isso, de certa forma resolvemos uma série de questionamentos que poderiam brotar da leitura do artigo 162, §2º do Código, à luz da Lei n ${ }^{\circ}$ 11.232/2005." Algumas implicações do novo conceito de sentença no Processo civil, de acordo com a Lei $n^{\circ} 11.232 / 2005$ in C. A. CARMONA (coord.), Reflexões sobre a Reforma do Código de Processo Civil - Estudos em homenagem a Ada Pellegrini Grinover, Cândido R. Dinamarco e Kazuo Watanabe, $1^{\text {a }}$ edição, São Paulo, Atlas, 2007, p. 189.

${ }^{102}$ É o que explica C. R. DinAmarco: “[q]uando o Código de Processo Civil abriu caminho para a ação rescisória contra sentenças de mérito, isso foi feito porque, no espírito e na precisão do legislador, só em sentença o mérito poderia ser julgado, ficando fora de cogitação que o fosse em decisões interlocutórias. Estas destinam-se a decidir sobre demandas ou temas incidentes ao processo, sem pôr fim a este e limitandose a prover sobre elas sem avançar sobre o meritum causœ. A extinção do processo, com ou sem julgamento do mérito, é feita por sentença (art. $162, \S 1^{\circ}$ ) e, da interpretação conjugada dos arts. 269, inc. I, e 459 do 
Com o advento da Lei $\mathrm{n}^{0} 11.232 / 2005$, divide-se a doutrina a respeito do enfrentamento das questões de mérito pelo juiz da causa antes do momento tradicionalmente reservado à prolação da sentença. Tendo em vista o já mencionado princípio da unirrecorribilidade, a caracterização destes pronunciamentos como "decisões interlocutórias de mérito" 103 ou como "sentenças de mérito parciais"104 teria relevância direta na determinação do recurso cabível.

A maior dificuldade reside nas hipóteses em que, pelo conteúdo do ato, se estaria diante de sentença que, porém, não decide toda a demanda, relegando a solução definitiva da controvérsia a momento posterior. Nesse contexto, surge dúvida a respeito do tipo de recurso cabível para impugnar a decisão que trate de alguma das situações previstas nos arts. 267 e 269, apesar de ter sido proferida antes do final da marcha processual.

Independentemente da corrente adotada - quer se considere haver decisões interlocutórias de mérito ou sentenças parciais - a doutrina propõe uma solução eminentemente pragmática para determinar o recurso cabível nesses casos: se a decisão tiver aptidão de encerrar o processo em primeiro grau de jurisdição, o recurso cabível é a apelação. Se, por outro lado, o processo deve prosseguir para que ainda outra decisão seja proferida, o pronunciamento será desafiável por agravo ${ }^{105}$.

Código de Processo Civil, resulta que todo o mérito será julgado em sentença e em só uma sentença." Ação rescisória contra decisão interlocutória in Nova era do Processo Civil, $1^{\mathrm{a}}$ edição, São Paulo, Malheiros, 2003, p. 281 - grifo do original. Ressalta-se que, apesar do afirmado, na análise do caso relatado, o processualista concluiu pela possibilidade de propor ação rescisória em face da decisão interlocutória que havia rejeitado a alegação de prescrição, ao fundamento de que se estaria diante de imperfeição de lei, que não oferecia a adequada solução para o fato da vida que se apresentava. Ação rescisória cit., p. 287.

${ }^{103}$ Por exemplo, A. DALL'AgnOL, para quem “[é] preciso superar a idéia de que o mérito seja exclusividade da sentença. No direito positivo brasileiro, não era antes, e não o é mesmo agora. Isso decorre da abrangência que o Código dá ao conceito de decisão interlocutória". Comentários cit., p. 272. Para P. H. S. LUCON, "[p]artindo-se de uma interpretação lógico-sistemática do Código de Processo Civil, com as alterações advindas da Lei 11.232/2005, a sentença é o ato que põe fim ao procedimento principal em primeiro grau de jurisdição, decidindo ou não o mérito da causa.” E prossegue: “[p]elas razões até aqui expostas, será sentença quando há a extinção do procedimento principal. Nos casos em que a decisão terminativa não tem esse efeito, o ato processual é decisão interlocutória.” Sentença e liquidação cit., pp. 911 e 912, respectivamente.

${ }^{104}$ Cf. T. A. A. WAMBIER, Os agravos cit., p. 113. Assim também H. V. M. SiCA, Preclusão cit., pp. 196197. O autor observa, no entanto, que "apesar da possibilidade de quebra do princípio da unicidade do julgamento do mérito, a Lei $\mathrm{n}^{0} 11.232 / 2005$ não foi apta a afastar a reserva do julgamento do mérito para a(s) sentença(s), sejam elas quantas forem." Preclusão cit., p. 197 - grifo do original.

105 "Em tais situações, o pronunciamento pode ter conteúdo de sentença, mas assim não será considerado, para fins de recorribilidade. (...) Assim, mesmo nos casos em que o pronunciamento judicial tem conteúdo encartável em uma das hipóteses referidas nos arts. 267 e 269 do CPC, não será cabível apelação, se parte do objeto do processo ainda depender de julgamento. A apelação somente será admissível se o pronunciamento jurisdicional, conquanto fundado no art. 267 ou no art. 269 do CPC, tiver esgotado a atividade cognitiva que deveria ter-se realizado perante o juízo de primeira instância, seja porque não há mais mérito a ser julgado, 
Diz-se pragmático, pois esse critério leva em consideração mais a consequência indesejada que adviria da interposição do recurso de apelação em face de sentenças parciais do que propriamente a definição de sentença atualmente vigente ${ }^{106}$.

Com efeito, pode-se imaginar que haveria prejuízo às partes em decorrência da paralisação do processo com a interposição de apelação contra cada decisão que versasse sobre alguma das hipóteses dos arts. 267 e 269, vez que este recurso se processa nos próprios autos, acarreta a remessa do processo ao tribunal ad quem e, via de regra, é dotado de efeito suspensivo.

Dessa forma, após a reforma, o recurso de agravo é cabível tanto para impugnar decisões interlocutórias propriamente ditas quanto para desafiar interlocutórias com conteúdo de sentença (ou sentenças parciais) ${ }^{107}$.

Delimitado o âmbito de cabimento de agravo, cabe agora tratar da disciplina desse recurso propriamente, o que se fará no capítulo seguinte.

seja porque o mérito não poderá ser julgado.” T. A. A. WAMBIER, Os agravos cit., pp. 112-113 - grifo do original. E conclui: "[e]m casos como os ora analisados, se estará diante de uma sentença que, excepcionalmente, poderá ser objeto de agravo", embora ressalvando que "a interposição de agravo, no entanto, não transforma, ipso facto, o conteúdo do pronunciamento." Os agravos cit., p. 113.

Para A. DE AsSIS, "A tese de que resoluções parciais do mérito, impropriamente tomadas no curso do processo, comportam apelação é inadmissível na vigência do CPC de 1973”. Manual cit., p. 373.

${ }^{106}$ Como expressamente admitem A. DE Assis: "[n]esses casos, cabe agravo, porque a apelação transtornaria a marcha firme e rápida do processo" (Manual cit., p. 373) e T. A. A. WAMBIER, "a fragmentação da causa, com a admissibilidade de apelação contra cada uma das sentenças 'parciais' proferidas ao longo do processo antes da sentença 'final', com a conseqüente paralisação do procedimento, se admitida, protrairia a resolução integral da lide, o que não é desejável, e contraria a finalidade do processo, que é a resolução integral e o mais rapidamente possível da lide" (Os agravos cit., p. 113 - grifo do original).

${ }^{107}$ Discorda desse posicionamento HEITOR SICA, para quem o pronunciamento que decide parcialmente a lide, implicando alguma das consequências dos arts. 267 e 269 do Código de Processo Civil, é sentença parcial, sendo cabível, portanto, o recurso de apelação. "O problema, então, não está propriamente em saber qual recurso é cabível contra a sentença parcial, pois, firme no comando do art. 513 do CPC, o caso é de apelação.” E prossegue: “[e]nquanto o legislador não reformar esse dispositivo, a dificuldade será adaptar o procedimento do recurso de apelação . desenhado para ser interposta ( sic) depois que o processo como um todo se encerrou em primeira instância, de regra suspendendo-o (CPC, artigo 520, caput) - para permitir que o processo prossiga quanto às demandas cumuladas que não foram solucionadas pela sentença parcial. Em outras palavras, trata-se de resolver uma questão procedimental, atinente à formação de autos para julgamento da apelação contra a sentença parcial." Algumas implicações cit., pp. 203 e 203-204, respectivamente - grifo do original. 


\section{O RECURSO DE AGRAVO}

\subsection{Agravo COMO RECURSO PARA A IMPUGNAÇÃo DE DECISÕeS INTERLOCUTÓRIAS POR EXCELÊNCIA}

Ensina a doutrina que o agravo surgiu no direito português medieval após a edição de lei ${ }^{108}$ que restringiu o cabimento da apelação às sentenças definitivas ${ }^{109}$ ou àquelas que tivessem força de definitivas, apenas ${ }^{110}$. Essa lei veio como reação à utilização indevida do recurso para estender indefinidamente a duração do processo ${ }^{111}$, que ocorria diante da possibilidade de interpor recurso de apelação contra as sentenças definitivas e interlocutórias ${ }^{112}$. Tratou-se, portanto, do resultado da preocupação com a razoável duração do processo e de tentativa de restabelecer a confiança na justiça.

Até então - antes da promulgação da referida lei - não havia a necessidade do recurso de agravo, pois, como já se mencionou, o recurso de apelação era cabível tanto

\footnotetext{
${ }^{108}$ Ordenações Afonsinas, livro III, título 72, §4º , cf. A. BuZAID, Do Agravo de Petição no sistema do Código de Processo Civil, tese (livre-docência em Direito Processual Civil) Faculdade de Direito Universidade de São Paulo, São Paulo, 1945, p. 35.

109 “Os agravos, por sua vez, surgiram depois que uma lei de Afonso IV, pretendendo corrigir os abusos resultantes do direito de apelar de qualquer sentença, restringiu o uso desse recurso, não podendo ser atacados numerosos despachos.” A. DE MENDONÇA LIMA, Introdução cit., pp. 18-19.

110 "Posteriormente, já no reinado de Afonso IV (1325-1357) impõem-se restrições ao direito de recorrer. Assim, tornam-se inapeláveis as decisões interlocutórias, salvo se tivessem força de definitiva, ou se impedissem que o juiz prolatasse uma decisão definitiva, ou, finalmente, se viessem a causar danos de difícil reparação. Em virtude dessa proibição é que surgem, posteriormente, contra as decisões inapeláveis, os estormentos de agravo, predecessores dos agravos. Essa restrição ao direito de apelar baseava-se na preocupação do prolongamento exacerbado dos processos.” O. N. S. LASPRO, Duplo grau cit., p. 65.

111 “A proliferação do recurso de apelação e sua extensão a todas as decisões proferidas no processo vieram causar graves prejuízos à marcha do juízo, devido às chicanas e expedientes protelatórios opostos ao procedimento, principalmente após a lei de D. Diniz, editada em 19 de março de 1317, que visava impedir que a classe nobre infundisse temor às partes no seu legítimo exercício do direito ao recurso." C. S. NORONHA, Do agravo cit., p. 15.
}

${ }^{112}$ M. LOBO DA COSTA ensina que a promulgação da referida lei foi consequência do crescente prestígio do direito romano justinianeu entre os portugueses após a fundação da Universidade de Lisboa, em 1290, quando passou a ser ensinado juntamente com o direito canônico. Cf. O agravo no direito lusitano in L. C. Azevedo, M. Lobo DA Costa, Estudos de história do processo - recursos, $1^{\text {a }}$ edição, São Paulo, Joen e FIEO, 1996, pp. 145-147.

“A ordenação de D. Afonso IV, sem dúvida, reagia contra a doutrina canônico-germânica que estabelecia a apelabilidade de todas as sentenças indiscriminadamente, ressalvando, porém, alguns casos em que a decisão interlocutória trazia à partes danos insuscetíveis de correção ou de difícil reparação na sentença final, o nos casos em que seria impossível reaver o gravame pela execução da interlocutória.” C. S. Noronha, Do agravo cit., p. 16. 
para impugnar sentenças definitivas como interlocutórias - e sua utilização era ampla ${ }^{113}$. A partir do momento em que houve a restrição à recorribilidade das interlocutórias, passou-se a formular pedidos ${ }^{114}$ (querimas ou querimonias) dirigidos ao juiz de grau superior ou ao próprio soberano ${ }^{115}$ para impugnar decisões em tese irrecorríveis ${ }^{116}$, caso o próprio juiz prolator não as revogasse após pedido de reconsideração ${ }^{117}$. Aparentemente, nesses pedidos reside o germe do agravo, tal como o conhecemos hoje $\mathrm{e}^{118}$.

113 “O recurso de agravo, até o reinado de D. Afonso III, era, portanto, inteiramente desconhecido, ou melhor, só existia, além da apelação, o de suplicação, ou sopricação, o qual vai receber pouco depois a denominação do agravo ordinário. Mas o que parece certo é que o agravo de petição, de instrumento e no auto do processo ainda não começam a se configurar. Pelo contrário. Difundia-se cada vez mais o uso da apelação, admissível não só contra as sentenças definitivas, mas também contras as interlocutórias, não só dos atos judiciais, como também dos extrajudiciais.” A. BUZAID, Do agravo cit., pp. 32-33, grifos do original.

114 “Realmente, a reação não tardou. O apelo ao Príncipe foi a solução encontrada. Assim, as partes, para obterem reparação do prejuízo sofrido, serviram-se de petições de queixas ou reclamações, chamadas querimas ou querimonias, dirigidas ao Monarca quando este percorria os domínios do reino para administrar justiça aos seus vassalos.” C. S. NORONHA, Do agravo cit., p. 18, grifos do original.

${ }^{115}$ Assim também A. BUZAID, para quem "a lei de D. Afonso IV, desejando tolher um mal, incidiu no erro contrário: com a restrição da faculdade de apelar, numerosos despachos ficaram sem recurso. Ora, esse estado de coisas criou grave insatisfação entre os litigantes, prejudicados por certas decisões, contra as quais a lei não autorizava qualquer remédio. Parece-nos que foi então que as partes, afim (sic) de obter reparação do gravame sofridos, se serviram das querimas, ou querimonias, levando as suas queixas ou reclamações ou magistrado do grau superior, ou ao soberano.” Do agravo cit., p. 36, grifos do original.

116 “As partes, então, utilizaram-se das antigas querimas ou querimonias, dirigidas ao magistrado de grau superior ou ao próprio soberano que, depois de conhecê-las e julgá-las, expediam cartas de justiça, que continham, porém, uma condição para sua eficácia: 'se assy he como querellou'. Para evitar os inconvenientes de uma ordem emanada por informação unilateral do interessado. D. Duarte vedou a concessão de cartas direitas por informação, salvo por instrumento de agravo ou carta testemunhável, com resposta do juiz ou do corregedor. Daí nasceu, sem dúvida, o agravo de instrumento. Mas apenas nas Ordenações Afonsinas é que dito recurso tomou feição nítida e regular.” A. DE MENDONÇA LiMA, Introdução cit., pp. 18-19.

117 "De par com a proibição de apelar contra a sentença interlocutória simples, foi erigida a regra de que todo juiz pode revogar sua sentença interlocutória antes de proferir a sentença definitiva (Livro III, Tít. 57). A revogação podia ocorrer a requerimento da parte agravada, até dez dias após a prolação da sentença, ou exofficio, a todo tempo antes de ser dada a sentença definitiva, se o juiz 'achar per Direito que nam foi justamente dada' e a quiser revogar de seu próprio juiz sem requerimento da parte (Tít. $67, \mathrm{n}^{\circ} 2$ )". M. LOBO DA CostA, $O$ agravo cit., p. 149, grifo do original. Na hipótese de o juiz não acolher o pedido de reforma, "o remédio então previsto era de ir queixar-se a el Rei." M. LOBO DA COSTA, O agravo cit., p. 150.

118 "Nas querimas parece residir o embrião dos agravos, segundo a mais autorizada doutrina. No entanto, os Estormentos d'agravo e as Cartas Testemunhavees, que as informavam e instruíam para o julgamento superior, ainda não configuravam o recurso de agravo, que só adquiriu caracteres definidos com as Ordenações Manoelinas, segundo opina Moacir (sic) Lobo da Costa.” C. S. NoronHA, Do agravo cit., p. 18, grifos do original.

E, no texto ao qual o processualista gaúcho faz referência, lê-se: “O Estormento d'agravo era então o instrumento escrito da antiga querima verbal, um meio para se pedir a correção do gravame produzido por sentença interlocutória simples contra a qual não era permitido apelar. É, assim, incontestavelmente o embrião do recurso de agravo; mas no regime das Ordenações Afonsinas ainda não tem as características de um recurso próprio.” M. LOBO DA COSTA, O agravo cit., p. 153. E o mesmo jurista complementa: “[é] o instrumento do agravo (gravame), mas, ainda não é o agravo de instrumento." O agravo cit., p. 153. 
Registra-se que há divergência a respeito da origem das diferentes modalidades de agravo - se no direito romano ou no direito português - que, contudo, por escapar ao objeto deste trabalho, não será abordada em profundidade ${ }^{119}$.

Seja como for, o que se pode observar é que, a partir de então, no direito lusitano e posteriormente no direito brasileiro, o agravo passou a ser o recurso para impugnação de decisões interlocutórias, diferenciando-se da apelação neste tocante. Tanto assim que é possível afirmar, com CARLOS SILveIRA NORONHA ${ }^{120}$ e HeITOR SiCA ${ }^{121}$, que o agravo é recurso tipicamente luso-brasileiro.

Isso não significa que outras legislações da chamada família de civil law não tenham desenvolvido mecanismos para a impugnação das decisões interlocutórias ao longo do processo. No entanto, o que ocorre é que, nesses sistemas, o recurso utilizado para este fim é o próprio recurso de apelação, que possui abrangência maior do que o nosso.

Para ilustrar, toma-se o exemplo da França, onde, segundo relatam PHILIPPE e NiCOLAS GERBAY, o princípio do duplo grau criou raízes profundas ${ }^{122}$. Lá, apelo é via de recurso que visa à reforma ou à anulação, pela qual uma parte que se entenda lesada por

${ }^{119}$ É o que relata A. DE MENDONÇA LIMA: "O antigo agravo ordinário teve sua origem na suplicatio romana. Há autores que divergem desta filiação considerando todo e qualquer agravo como instituto genuinamente luso, oriundo das querimas ou querimonias." Introdução cit., p. 19.

No mesmo sentido, C. S. NORONHA: “A suplicação, resultante do precedente romano, dava origem a um novo recurso que deveria integrar o sistema lusitano: o agravo ordinário." Do agravo cit., p. 14. Este processualista gaúcho explica que "[o] agravo ordinário, como sucedâneo da apelação, desapareceu no sistema português com as reformas processuais a partir da publicação do Decreto $n^{0} 24$, de 16 de maio de 1832, não chegando a se integrar ao sistema de recursos adotado pelo primeiro Código de Processo Civil de Portugal, editado em 1876." Do agravo cit., p. 15.

120 "Na legislação estrangeira há meios recursais de ataque às decisões interlocutórias que revelam alguns traços comuns à figura do agravo do direito luso-brasileiro, ainda que tais elementos não sejam sudicientes para uma perfeita identificação entre o nosso recurso e os alienígenas." E conclui: "não é difícil concluir que o agravo de instrumento, como, de resto, os agravos de petição e no auto do processo são recursos estritamente luso-brasileiros, confirmando-se, deste modo, a posição já desde muito assumida neste particular pelos processualistas brasileiros e portugueses. Nenhuma legislação anterior ou posterior à portuguesa preocupou-se com a adoção do recurso de agravo, salvo o processo romano, no que diz respeito à figura da supplicatio, que é fonte do agravo ordinário. Ao contrário, para a impugnação das interlocutórias muitas ordenações processuais valeram-se do recurso de apelação, enquanto outras empregaram diversificadas espécies com o mesmo fim, sem qualquer possibilidade de sua identificação com o agravo de instrumento." Do agravo cit., pp. 49 e 65-66, respectivamente - grifo do original.

${ }^{121}$ Cf. Recorribilidade das interlocutórias cit., pp. 168-169.

122 "Le double degré de juridiction est totalement enraciné dans notre modèle judiciaire. Le plaideur ayant succombé en première instance doit pouvoir faire rejuger son affaire par une juridiction plus expérimentée bénéficiant de surcroît de l'analyse du premier juge. On peut y voir là une garantie de bonne justice, voire une sauvegarde des libertés publiques. L'appel est une voie de recours 'ordinaire' mais ce mot doit être entendu dans toute sa noblesse.” Guide du Procès Civil en appel, $1^{\mathrm{a}}$ edição, Paris, Lexis Nexis, 2012, p. Ix. 
um julgamento submete o processo e a decisão a magistrados de grau superior ${ }^{123}$. Sendo meio de impugnação ordinário e de droit commun, a apelação está à disposição de todos os jurisdicionados, como garantia de justiça e salvaguarda das liberdades públicas, especialmente o direito de provocar a censura de um grau superior de jurisdição sobre uma determinada decisão ${ }^{124}$. Ainda, o recurso de appel tem cabimento amplo, sendo possível seu manejo em face de pronunciamentos jurisdicionais definitivos ${ }^{125}$, provisórios ${ }^{126} \mathrm{ou}$ $\operatorname{mistos}^{127}$.

Exceção a essa regra são os pronunciamentos avant dire droit ${ }^{128}$, que versam sobre medidas provisórias - destinadas a proteger a parte contra eventual dano decorrente do transcurso do tempo ao longo do processo - ou relativamente a medidas de instrução.

${ }^{123}$ J. VINCENT e S. GUINCHARD, "L'appel est une voie de recours de droit commun et de réformation ou d'annulation par laquelle une partir qui se croit lésée par un jugement, défère le procès et le jugement aux juges du degré supérieur." Procédure civile, 20a edição, Paris, Dalloz, 1981, p. 785 - grifo do original.

${ }^{124}$ Nesse sentido, J. L. GALLET: "Traditionnellement présenté comme une voie de réexamen et une voie d'achèvement des litiges, sa finalité est ainsi étroitement délimitée. S'il est souvent qualifié de 'voie de recours par excellence', s'inscrivant dans une logique de perfectionnement d'une vérité judiciaire', il ne relève cependant pas, en droit positif, en matière civile, d'une norme ayant une valeur supra-législative susceptible de l'ériger en droit absolu." La procedure civile devant la Cour d'Appel, $2^{\mathrm{a}}$ edição, Paris, Lexis Nexis Litec, 2010, p. 3.

125 "Le jugement définitif est celui qui règle soit tout le procès ou seulement certains points du procès, soit des incidents autres que ceux relatifs à des mesures d'instruction et à des demandes provisoires, de telle façon que l'examen du juge n'ait plus à s'exercer sur les points tranchés par ce jugement. Ainsi, tout jugement qui se prononce sur le fond du droit est un jugement définitif (art. 480, nouv. C.); tour jugement qui tranche in incident, comme celui qui est soulevé par une exception d'incompétence, est un jugement définitif; il en est de même des jugements qui interviennent sur la validité ou la nullité de tel acte de procédure (art. 544, al. 2, nouv. C.)." Procédure civile cit., p. 684 - grifo do original.

126 "Par opposition aux jugements définitifs les jugements dits provisoires sont ceux qui ne tranchent pas le fond du procès, mais statuent sur un chef urgent de demande. On peut en distinguer deux grandes catégories: - En premier lieu, les jugements provisoires par leur nature, qui n'ont jamais autorité de la chose jugée au principal, quel que soit leur objet. On trouve par exemple, les ordonnances de référé (art. 484) ou les ordonnances sur requête (art. 493), ou encore les ordonnances du juge de la mise en état. - En second lieu, les jugements dits provisoires parce qu'ils ordonnent des mesures elles-mêmes provisoires, c'est-à-dire essentiellement révisables". J. VINCENT e S. GuINCHARD, Procédure civile cit., p. 685 - grifos do original.

${ }^{127} \mathrm{O}$ julgamento chamado misto é "à la fois définitif et avant dire droit”. É o tipo de pronunciamento que se obtém, segundo a classificação de J. VINCENT e S. GUINCHARD, quando se profere sentença condenatória genérica, relegando-se a apuração do montante devido a liquidação de sentença. Explicam os processualistas franceses: "Un tel jugement s'oppose aux jugements définitifs en ce qu'il ne tranche pas tout le litige; certaines questions restent en suspens et le juge demeure saisi pour en connaître. Il s'oppose aussi aux jugements avant dire droit parce qu'il ne se contente pas de prendre des mesures provisoires ou des mesures d'instruction; il tranche certaines questions de fond; du fait de cette dualité il est soumis à un régime juridique particulier." Procédure civile cit., pp. 690-691.

${ }^{128}$ Trata-se do pronunciamento judicial proferido "avant que le juge ne dise le droit sur la contestation", e se divide em duas categorias: "La première comprend les jugements ordonnant une mesure provisoire, la seconde groupe les jugements relatifs à l'instruction.” J. VINCENT e S. GUINCHARD, Procédure civile cit., p. 686 - grifos do original. 
Estes não se submetem à autoridade da coisa julgada, e não possuem previsão de meio de impugnação imediato ${ }^{129}$.

Retomando, tem-se que a função do agravo no sistema consiste, de um lado, em evitar que recaia a preclusão sobre a questão enfrentada na decisão interlocutória tanto para as partes quanto para o juiz - no caso do agravo retido e, de outro, em permitir a revisão imediata de determinadas decisões, nos casos em que houver urgência ou quando não se puder cogitar de análise juntamente com a apelação (ou seja, quando já tiver sido proferida sentença), pelo agravo de instrumento.

Nesta modalidade, o agravo responde a um ideal de dinamismo do sistema recursal, na medida em que pode propiciar a imediata revisão de decisão que tenha causado gravame à parte.

Trata-se de recurso cuja existência decorre do reconhecimento de que, ao longo do processo - entre a formulação da demanda e a prolação da sentença -, o juiz deve decidir inúmeras questões que podem influenciar na sentença a ser proferida ${ }^{130}$. Atualmente, todas as decisões interlocutórias podem ser alvo de ataque pela via do agravo - e é justamente o sistema de recorribilidade plena das decisões interlocutórias o alvo da proposta de reforma legislativa que se pretende impor com o Projeto de Novo Código de Processo Civil.

Conforme já se adiantou, o objeto deste estudo é apenas o agravo interponível contra decisões interlocutórias proferidas em primeiro grau de jurisdição, ficando, assim, excluídas as decisões (i) relativas à admissibilidade de recurso especial e extraordinário; (ii) que julgam monocraticamente outros recursos; e (iii) proferidas em mandado de segurança.

\footnotetext{
129 "Si la voie de l'appel est (sauf disposition contraire) ouverte contre toute décision de justice, il convient de souligner que, s'agissant de certains jugements, elle ne peut pas être utilisée immédiatement. C'est normalement le cas pour les jugements avan dire droit qui, sauf lorsque la loi en dispose autrement, ne peuvent être frappés d'appel indépendamment des jugements sur le fond." G. COUCHEZ, Procédure civile, $4^{\mathrm{a}}$ edição, Paris, Sirey, 1986, pp. 282-283.

130 " $\mathrm{Da}$ admissibilidade da demanda até o pronunciamento de mérito, o juiz emite variados provimentos intermediários, e de importância desigual, chamados de decisões interlocutórias no art. 162, $\$ 2^{\circ}$ (retro, 19.1.2). Ao juiz não se põem, de plano ou em bloco, todas as questões necessárias ao julgamento definitivo do mérito. Na verdade, elas se apresentam progressivamente e conforme as variantes do procedimento. Daí originarem um número expressivo de decisões proferidas em ocasiões diferentes. A impugnação autônoma desses provimentos assumiu papel destacado no processo civil contemporâneo. É um grave e decisivo problema de política legislativa. Sua solução, marcada por forças antagônicas, em boa medida define a espécie do processo efetivamente utilizado no País.” A. DE AssIs, Manual cit., p. 462.
} 


\subsection{AtUal Regime do agravo}

Conforme já se acenou, o agravo é o recurso cabível contra decisões interlocutórias proferidas no curso do processo de conhecimento (art. 522 do Código de Processo Civil). Atualmente, são previstas duas modalidades: de instrumento e retido. Após as modificações introduzidas pela Lei $\mathrm{n}^{\mathrm{o}} 11.187 / 2005$, o agravo retido - que pode ser escrito ou oral, se dirigido contra decisão proferida em audiência de instrução e julgamento ${ }^{131}$ - passou a ser a regra do sistema de impugnação às decisões interlocutórias $^{132}$.

De acordo com o procedimento do agravo retido, o inconformismo com relação ao teor de determinada decisão interlocutória deve ser manifestado no prazo de dez dias da intimação do seu teor, mas a apreciação das razões de recurso pelo órgão a quo está condicionada primeiramente à interposição, pelo agravante, de recurso de apelação contra a futura sentença e também à reiteração, em preliminar de apelação, do interesse no conhecimento do agravo (art. 523).

O agravo de instrumento é, portanto, ao menos em teoria ${ }^{133}$, modalidade excepcional de recurso que promove a revisão imediata da decisão agravada, que deve ser interposto diretamente junto ao Tribunal competente para julgá-lo. Essa excepcionalidade se evidencia, de um lado, pela circunstância de esta espécie de agravo estar condicionada

131 “Quid iuris, se a decisão, proferida no curso da audiência de instrução e julgamento, acarretar lesão grave e de difícil reparação? Aqui, o art. 522 incide. Deve o sucumbente ou outro legitimado interpor agravo de instrumento, indispensável a ressalva, feita na própria audiência e posta no respectivo termo, de que se irá recorrer ao tribunal, para que o prosseguimento da audiência não configure aceitação tácita (art. 503 e parágrafo único)." S. BERMUDES, Considerações sobre a nova sistemática do agravo no Código de Processo Civil, in A. F. FABRícIO, Meios de impugnação ao julgado civil - estudos em homenagem José Carlos Barbosa Moreira, Rio de Janeiro, 2007, p. 508. Da mesma forma, A. G. CARNEIRO, Do recurso de agravo e suas alterações pela lei $n^{\circ} 11.187 / 05$, in A. F. FABRícIO, Meios de impugnação ao julgado civil-estudos em homenagem José Carlos Barbosa Moreira, Rio de Janeiro, 2007, pp. 126 e 127.

${ }^{132}$ Além da própria redação da lei, há consenso na doutrina a respeito da prevalência do agravo retido como regra no sistema, modificação que teria decorrido da preocupação do legislador com "o excesso tumultuário do uso do agravo de instrumento que, segundo reclamos dos Tribunais, embaraçava inconvenientemente a tramitação e julgamento dos demais recursos em segunda instância”. H. THEODORO JR., Curso cit., p. 600.

${ }^{133}$ Diz se, "em teoria” para ressalvar a opinião de A. G. CARNEIRO, para quem "[b]em pensando, o recursopadrão das interlocutórias era, e continuará a ser, o agravo por instrumento, permissivo de uma breve solução da questão incidental, mantendo-se o agravo retido numa posição ancilar, empregado em hipóteses de menor importância." Do recurso de agravo cit., p. 127. 
ao risco de dano irreparável ou de difícil reparação e, de outro, pela possibilidade franqueada ao relator do recurso de convertê-lo em agravo retido por decisão irrecorrível.

O prazo para interposição do agravo de instrumento - que deverá ser feita diretamente perante o órgão ad quem - é também de dez dias a partir da data de intimação da decisão (art. 524). Cabe ao agravante o ônus da correta formação do instrumento, com as peças obrigatórias, "necessárias" e facultativas, sob pena de não conhecimento do recurso (art. 525). Ademais, cabe também ao agravante informar o juízo de origem a respeito da interposição do recurso, juntando cópia da petição respectiva e relação dos documentos que o instruíram (art. 526), de modo a provocar o juízo de retratação pelo prolator da decisão agravada, sob pena de inadmissibilidade do recurso (art. 526, parágrafo único).

A reforma promovida pela Lei $n^{0} 10.352 / 2001$ ampliou os poderes do relator a quem é distribuído o agravo de instrumento, conferindo-lhe (i) o poder-dever de negar seguimento ao recurso nas hipóteses do art. 557 do Código de Processo Civil (se for manifestamente inadmissível, improcedente, prejudicado ou em confronto com súmula ou jurisprudência dominante do respectivo tribunal, do Supremo Tribunal Federal ou de Tribunal Superior) (art. 527, I); (ii) a possibilidade de atribuir efeito suspensivo ao recurso, ou conceder tutela antecipada recursal (art. 527, III), por decisão irrecorrível; e (iii) a possibilidade de requisitar informações ao juiz da causa (art. 527, IV).

Essa tendência foi acentuada pela Lei $\mathrm{n}^{0} 11.187 / 2005$, que possibilitou ao relator converter o agravo de instrumento em retido, também por decisão irrecorrível (art. 527, II), além de regulamentar a forma de intimação do agravado e do Ministério Público para contrarrazões e manifestação, se o caso.

Em relação às decisões interlocutórias proferidas em sede de cumprimento de sentença, após a modificação do conceito de sentença introduzida no sistema pela Lei $\mathrm{n}^{\circ}$ 11.232/2005, não é cabível agravo retido, por não haver a possibilidade de reiterá-lo em posterior recurso de apelação.

Deixando de lado outras minúcias procedimentais que distinguem as mencionadas modalidades de agravo - que pouco interessam ao tema que se pretende 
desenvolver - é possível afirmar, com MONIZ DE ARAGÃO ${ }^{134}$, que, atualmente não se pode prescindir de um meio de impugnação imediata das decisões interlocutórias.

Mais do que isso, tem-se que a atual estruturação do recurso de agravo se presta adequadamente aos fins a que se destina, já mencionados, na medida em que (i) oferece às partes meio eficiente (tanto do ponto de vista da técnica como do tempo despendido entre a interposição e uma primeira análise do relator) de impugnação das decisões interlocutórias, com a possibilidade de revisão "imediata" do pronunciamento judicial desfavorável; (ii) promove o juízo de retratação do magistrado de primeiro grau, também em curto prazo.

A "eficiência" do recurso é aspecto que cresce em importância ante a proliferação das tutelas de urgência, por meio das quais o juiz emite pronunciamentos cuja eficácia pode se projetar para fora do projeto antes da prolação da sentença, preenchidas as condições dos arts. 273, 461, §3º , e 798 do Código de Processo Civil. Essa circunstância, em especial, contribui sobremaneira para a defesa da necessidade de um meio de impugnação da decisão concessiva de tutela diferenciada que independa do recurso de apelação.

Outro tipo de decisão interlocutória que evidencia a necessidade do recurso de apreciação imediata é aquela que versa sobre intervenção de terceiros, eis que o provimento do recurso somente após a prolação da sentença traria em si o risco de o processo todo vir a ser anulado. Ainda, pode-se mencionar como exemplo as decisões interlocutórias proferidas após a sentença, em sede de liquidação ou cumprimento: nesses casos, o agravo deve ser por instrumento, pois não haverá futuro recurso de apelação em cuja preliminar se pudesse reiterar o agravo retido.

É do que se tratará no próximo tópico.

\footnotetext{
${ }^{134}$ Para ele, os recursos de apelação, agravo e extraordinário "atendem aos interesses da brevidade e certeza, interesses que devem ser ponderados - como na fórmula da composição dos medicamentos - para dar adequado remédio às necessidades do processo judicial. mas um não deve apoucar o outro, há de conviver, tal como a harmonia e a independência dos Poderes de que fala o art. $2^{\circ}$ da Constituição. E mais: é insuportável que para privilegiar a brevidade sejam atropeladas garantias constitucionais asseguradas aos litigantes, assim ao autor como ao réu. Ao falar na divisão do 'tempo do processo' há quem não hesite em sustentar a primazia da atenção a ser dispensada ao autor, à brevidade, portanto, mesmo ao custo, como disse, de serem afetadas não somente a certeza como as garantias inerentes ao devido processo." Demasiados recursos? cit., pp. 189-190.
} 


\subsection{DA FÓRMULA DISTINTIVA GENÉRICA "LESÃO GRAVE E DE DIFÍCIL REPARAÇÃO” E SUA IMPLICAÇÃO}

Sendo impugnáveis todas as decisões interlocutórias, definidas na forma já explicada, e não cabendo em tese ao recorrente a escolha da modalidade de agravo a ser interposta, é importante analisar sumariamente os traços legais que permitem identificar o recurso cabível contra as decisões interlocutórias proferidas em primeiro grau de jurisdição. $\mathrm{O}$ exame não englobará as interlocutórias proferidas após a prolação de sentença, pois, quanto a essas, por expressa disposição legal, o recurso cabível é o de agravo de instrumento, por razões lógicas (se já foi proferida sentença, a interposição de agravo retido implicaria em que o recurso jamais seria apreciado, pois o recorrente não teria a oportunidade de reiterá-lo como preliminar de eventual apelação).

O primeiro fator que diferencia as duas espécies de agravo, no âmbito das decisões interlocutórias proferidas no curso da fase de conhecimento do processo, além da urgência na revisão - consistente na suscetibilidade de a decisão agravada gerar lesão grave e de difícil reparação - é a utilidade do recurso. Nesse sentido, são suscetíveis de agravo por instrumento também as decisões cuja revisão seria inútil se ocorresse somente após a prolação de sentença ${ }^{135}$.

Como já se mencionou, o agravo retido é, em teoria, a regra. No entanto, como observa HeITOR SICA, possivelmente no caso dos recursos contra decisões interlocutórias, as hipóteses teoricamente enquadráveis como exceção são mais numerosas do que a própria regra ${ }^{136}$. Para explicar o raciocínio, o processualista divide as decisões interlocutórias em duas categorias, para fins de delimitar o cabimento de agravo de instrumento: aquelas que podem causar prejuízo imediato à parte - ou seja, dano que não poderá ser afastado pela sentença ou por acórdão que julgue recurso de apelação -, e aquelas cujo prejuízo é potencial.

\footnotetext{
135 "Impende verificar, isto sim, se o gravame (alegadamente) sofrido pela parte, por sua natureza e efeitos, comporta um regime de espera pela futura apelação, e se, caso provido pelo tribunal, o decurso do tempo não fará desaparecer a possibilidade de uma ainda eficaz reparação do dano causado. Ou seja: se o recurso mantém sua capacidade de reparação do gravame.” A. G. CARNEIRO, Do recurso de agravo cit., p. 125 “ grifo do original.

${ }^{136}$ Cf. O agravo e o "mito de Prometeu": considerações sobre a Lei 11.187/2005 in N. NERY JR., T. A. A. WAMBIER (coords.), Aspectos polêmicos e atuais dos recursos cíveis e assuntos afins, v. 9, $1^{\mathrm{a}}$ edição, São Paulo, Revista dos Tribunais, 2006, pp. 197-209.
} 
Ocorre, porém, que a imensa maioria das decisões interlocutórias se enquadra no primeiro grupo, restando para o segundo somente aquelas que versam sobre matéria probatória ou que rejeitam questões preliminares, entendendo pela regularidade do processo $^{137}$.

Mais do que isso: a locução "lesão grave e de difícil reparação" é extremamente genérica, verdadeiro conceito juridicamente indeterminado que possibilita diversas interpretações, e conduz ao inconveniente do elenco casuístico de hipóteses em que é cabível agravo de instrumento, sob pena de dano irreparável ou de difícil reparação. Para ilustrar, na sequência se tratará de duas dessas situações, relativas às tutelas de urgência e às intervenções de terceiros, pela assistência.

\subsubsection{DAS TUTELAS DE URGÊNCIA}

Talvez a mais emblemática situação a evidenciar a necessidade de manutenção de recurso de impugnação imediata das decisões interlocutórias seja a possibilidade de concessão de tutelas de urgência (antecipatórias e cautelares) prevista pelo Código de Processo Civil, nos arts. 273, 461, §3º e 798 do Código de Processo Civil.

CÂNDIDO DINAMARCO se refere à tutela jurisdicional diferenciada como "a proteção concedida em via jurisdicional mediante meios processuais particularmente ágeis e com fundamento em uma cognição sumária" ${ }^{138}$. Em complemento, BEDAQUE explica que a expressão possui dois sentidos distintos, podendo se referir a procedimentos de cognição plena elaborados tendo em vista as especificidades da relação de direito material que visam tutelar ou à regulamentação de tutelas sumárias (precedidas de

\footnotetext{
137 “(...) podemos classificar em duas categorias distintas as decisões interlocutórias, sob o prisma de a possibilidade causar (sic) dano à parte: aquelas que geram prejuízo meramente potencial, que pode ser integralmente afastado pela sentença de $1^{\circ}$ grau, e aquelas que geram prejuízo imediato, não passível de ser afastado eficazmente nem pela sentença, nem por eventual acórdão que julgar recurso de apelação contra ela dirigido. Segundo a leitura que ora fazemos da nova legislação em comento, é somente quanto a essa segunda categoria que caberia o agravo de instrumento." Continua: "Nessa primeira categoria estão, claramente, as decisões interlocutórias em matéria probatória." "Na mesma categoria de decisões da qual emerge risco de dano passível de reparação pela sentença estão todas aquelas decisões que rejeitam questões preliminares, dando pela regularidade do processo quanto às condições da ação e pressupostos processuais." E conclui: "[a]fora esses casos, parece-nos que todas as demais interlocutórias são passiveis de gerar risco de difícil reparação, em maior ou menor grau." O agravo e o "mito de Prometeu" cit., pp. 198, 198, 199-200 e 200, respectivamente - grifos do original.

${ }^{138}$ Cf. Instituições Instituições de Direito Processual Civil, v. 3, $1^{\mathrm{a}}$ edição, São Paulo, Malheiros, 2001, p. 733 - grifo do original.
} 
cognição não exauriente) com o fim de conferir maior efetividade ao processo ${ }^{139}$. Essa segunda acepção do termo é a que interessa ao objeto deste estudo.

Os provimentos de natureza cautelar e antecipatória são tutelas jurisdicionais diferenciadas em decorrência da sumarização da cognição que lhes precede, que reflete a preocupação com a efetividade do processo em que estão inseridas. Outro traço comum entre ambas é a sua inaptidão para formar coisa julgada no sistema atual, sendo-lhes inerente os atributos da provisoriedade e revocabilidade. Por essa razão, BEDAQUE propõe a reunião de ambas sob a denominação "tutelas de urgência"140.

O que distingue a tutela antecipada da cautelar, do ponto de vista conceitual, é o caráter satisfativo da primeira, que permite à parte desde logo a fruição do bem da vida pleiteado, em contraposição ao caráter conservativo da tutela cautelar, que em tese objetiva apenas a garantir a efetividade do provimento final ${ }^{141}$. Porém, a distinção é de pouca valia a partir do enfoque que se lhes pretende dar - atinente à necessidade de previsão de meios para a impugnação imediata das decisões a seu respeito -, especialmente à luz da fungibilidade das tutelas de urgência estabelecida pelo art. $273, \S 7^{\circ}$, do Código de Processo Civil $^{142}$, razão pela qual se buscará, na medida do possível, tratá-las em conjunto, evidenciando eventuais peculiaridades, quando imprescindível.

139 “A expressão tutela jurisdicional diferenciada pode ser entendida de duas maneiras diversas: a existência de procedimentos específicos, de cognição plena e exauriente, cada qual elaborado em função de especificidades da relação material; ou a regulamentação de tutelas sumárias típicas, precedidas de cognição não exauriente, visando a evitar que o tempo possa comprometer o resultado do processo." Tutela cautelar e tutela antecipada: tutelas sumárias e de urgência (tentativa de sistematização), $5^{\mathrm{a}}$ edição, São Paulo, Malheiros, 2009, p. 25 - grifo do original.

${ }^{140} \mathrm{O}$ processualista explica que a tutela cautelar e a antecipatória "[s]ão modalidades de tutela jurisdicional que, com variações decorrentes das especificidades da relação de direito material ou de técnicas legislativas, podem ser classificadas numa categoria única, à qual se mostra adequada a denominação tutelas de urgência." Tutela cautelar cit., p. 26 - grifo do original.

141 “A tutela antecipatória é satisfativa, parcial ou totalmente, da própria tutela postulada na ação de conhecimento. A satisfação se dá através do adiantamento dos efeitos, no todo ou em parte, do provimento postulado. Já na tutela cautelar, segundo a doutrina dominante, há apenas a concessão de medidas colaterais que, diante da situação objetiva de perigo, procuram preservar as provas ou a assegurar a frutuosidade do provimento da 'ação principal'. Não é dotado, assim, de caráter satisfativo, a menos que se aceite, como o fazemos, a existência de direito substancial de cautela, que é satisfeito pelo provimento concessivo da tutela cautelar. A discussão a respeito, porém, não cabe ser desenvolvida neste trabalho." K. WATANABE, Tutela antecipatória e tutela específica das obrigações de fazer e não fazer - arts. 273 e 461, CPC, obtido em www.rtoline.com.br, originalmente publicado em Revista de Direito do Consumidor, 19:1996, pp. 77 e seguintes, p. 11 (arquivo eletrônico).

142 "Se o autor, a título de antecipação de tutela, requerer providência de natureza cautelar, poderá o juiz, quando presentes os respectivos pressupostos, deferir a medida cautelar em caráter incidental do processo ajuizado". Modificação introduzida pela lei no 10.444/2002. 
A diferenciação em relação à tutela jurisdicional proveniente de cognição exauriente pode se dar tanto na extensão horizontal quanto na profundidade vertical da cognição; ou seja, pode-se limitar as pretensões que poderiam ser analisadas ${ }^{143}$ e/ou determinar que a decisão possa ser proferida mediante análise superficial da questão, a partir de juízos de verossimilhança e probabilidade ${ }^{144}$. A cumulação entre essas duas técnicas é frequente, mas não necessária, e depende de opção legislativa.

De todo modo, a urgência - entendida como a impossibilidade de aguardar o trâmite completo do processo em determinadas situações, sob pena de agravá-las a ponto de causarem danos irreversíveis às partes - é traço comum às tutelas antecipatória e cautelar ${ }^{145}$. Aliás, essa é a principal justificativa para a previsão de tutelas de urgência no sistema processual: são mecanismos de proteção da parte que aparenta ter razão, que atuam contra o dano causado pelo transcurso do tempo pela redistribuição do ônus de aguardar o julgamento do processo $^{146}$.

Em contrapartida à sumarização da cognição, a possibilidade de concessão de tutelas de urgência em nosso sistema está condicionada à observância de requisitos destinados a conferir maior segurança ao provimento ${ }^{147}$, relacionados, de um lado, à

${ }^{143}$ A. G. CARNEIRO ensina que cumpre "a um processo civil moderno, instituir uma redistribuição dos ônus processuais naturalmente decorrentes do transcurso do tempo, e, para tanto, impuseram-se formas diferenciadas de tutela. Neste passo, vale distinguir: a) as formas de tutela com sumarização do procedimento, as quais, embora mantendo a cognição exauriente, buscam abreviar a prolação da sentença de mérito, dotada de eficácia de coisa julgada material; b) as formas de tutela com sumarização da cognição, as quais, com base em cognição não exauriente, buscam a preservação provisória e temporária dos interesses do litigante que, tendo em seu favor a aparência do bom direito, razoavelmente possa invocar prejuízo grave decorrente da duração do processo". Da antecipação de tutela, $6^{\mathrm{a}}$ edição, atualizada em conformidade com as leis $\mathrm{n}^{\mathrm{o}}$ 10.352, de 26.12.2001, $\mathrm{n}^{\mathrm{o}}$ 10.358, de 27.12.2001 e $\mathrm{n}^{\mathrm{o}}$ 10.444, de 07.07.2002, Rio de Janeiro, Forense, 2006, p. 5 - grifos do original. No mesmo sentido, C. R. DinAmARCO, Instituições cit., v. 3, p. 37.

${ }^{144}$ Cf. K. WATANABE, Cognição no processo civil, $4^{\mathrm{a}}$ edição, revista e atualizada, São Paulo, Saraiva, 2012, p. 132.

145 "La funzione dei provvedimenti d'urgenza è il munire di tutela sommaria urgente (sia pure attraverso la tecnica propria dei procedimenti sommari cautelari) tutti i diritti purché, oltre al requisito generalissimo del fumus boni iuris (requisito non previsto esplicitamente dagli art. 700 ss. ma da essi presupposto), il titolare abbia 'fondato motivo di temere che durante il tempo occorrente per far valere il diritto in via ordinaria, questo (cioè il suo preteso diritto) sia minacciato da un pregiudizio imminente ed irreparabile"'. A. PROTO PISANI, Appunti sulla giustizia civile, $1^{\text {a }}$ edição, Bari, Cacucci, 1982, p. 358.

${ }^{146}$ C. R. DinAmARCO, comentando a reforma que generalizou a possibilidade de concessão de tutela antecipada em 1994 afirma que "veio com o objetivo de ser uma arma poderosíssima contra os males corrosivos do tempo no processo." A reforma do Código de Processo Civil, $3^{\mathrm{a}}$ edição revista, ampliada e atualizada, São Paulo, Malheiros, 1996, p. 140.

${ }^{147}$ É o que ensina C. R. DinAMARCO: "o reduzido nível de imunidade das decisões concessivas de cautela antecipada (sua provisoriedade) não é motivo para descuidar das atividades instrutórias inerentes à indispensável cognição sumária. A probabilidade exigida pela lei ao falar em prova inequívoca significa que até a algum grau de investigações o juiz deve chegar”. A reforma cit., p. 146. 
existência de início de prova a concluir pela procedência do pedido e à urgência ou abuso do direito de defesa do réu (no caso do art. 273, II, do Código de Processo Civil), de outro.

Neste último caso, embora não se possa falar propriamente em urgência, reconhece-se que a demora decorrente do comportamento protelatório do réu impõe ao autor ônus que não é legítimo determinar que suporte, uma vez demonstrada a probabilidade do seu direito. Dito de outra forma, para fins de antecipação decorrente de comportamento desleal do réu, de maneira semelhante ao que ocorre com as tutelas antecipatória ou cautelar baseadas na urgência, parte-se da ideia de que "a celeridade na tutela é em si mesmo um bem"148.

O requisito da demonstração da probabilidade do direito alegado (prova inequívoca que convença da verossimilhança da alegação, na dicção do art. 273, relevância do fundamento da demanda, segundo o art. 461, $\$ 3^{\circ}$, ou ainda fumus boni iuris, comumente referido pela doutrina a respeito da tutela cautelar) reflete a necessidade, tanto na modalidade de tutela antecipada quanto cautelar, de análise, ainda que superficial, da questão de direito material que envolve o pedido para concluir pela plausibilidade da alegação. Essa plausibilidade deve conduzir a juízo favorável ao requerente ${ }^{149}$, mas não deve equivaler à certeza por parte do julgador, pois nessa hipótese ele deveria julgar imediatamente o feito.

Dito de outra forma, é necessário que haja prova apta a conduzir o julgador a um juízo de probabilidade favorável à pretensão do requerente. Convém ainda registrar que grande parte da doutrina entende que a verossimilhança fundada na prova inequívoca do

\footnotetext{
${ }^{148}$ C. R. Dinamarco, A reforma cit., p. 148.

${ }^{149}$ Como bem explica E. FIDÉLIS DOS SANTOS: “[s]e existem motivos maiores para se crer e motivos para não se crer, o fato será simplesmente possível; se os motivos para se crer são maiores, o fato já será provável; se todos os motivos são para se crer, sem nenhum para não se crer, o fato será de probabilidade máxima. Verossimilhança, pois, e prova inequívoca são conceitos que se completam exatamente para informar que a antecipação da tutela só pode ocorrer na hipótese de juízo de máxima probabilidade, a certeza, ainda que provisória, revelada por fundamentação fática, onde presentes estão apenas motivos positivos de crença”. E prossegue: "Não havendo a prova concludente, mas sendo fortes os motivos de crença, a verossimilhança não deixa de existir, mas, neste caso, o juízo de máxima probabilidade cede lugar à simples possibilidade, mera aparência que pode revelar o fumus boni iuris, informador apenas da tutela cautelar. (...) A antecipação pode ser dada a qualquer momento do processo, ficando a critério do juiz ouvir ou não o réu, antecipadamente, se requerida como liminar, mas, se não houver a prova inequívoca, isto é, a que, desde já e por si só, permita a compreensão do fato como juízo de certeza, pelo menos provisória, não será possível, mormente quando o entendimento do juiz depende da colheita de outros elementos probatórios, para, depois, em análise do conjunto, extrair a conclusão". Novos perfis do processo civil brasileiro, Belo Horizonte, Del Rey, 1996, pp. 24 e $30 / 31$.
} 
art. 273 do Código de Processo Civil exige demonstração mais contundente do que o simples fumus boni iuris fundado no poder geral de cautela do juiz (art. 798 do CPC) ${ }^{150}$.

Essa circunstância, contudo, não afasta a necessidade de embasamento da pretensão em suporte probatório mesmo no segundo caso - até porque, se assim não fosse, estar-se-ia, na palavras de BEDAQUE, desvirtuando o poder geral de cautela em "via sumária de resolução de conflitos"151.

Cumulado com a probabilidade está o requisito comum às tutelas antecipatória e cautelar do risco de dano decorrente da demora ("fundado receio de dano irreparável ou de difícil reparação", segundo o art. 273, I, do Código de Processo Civil, “justificado receio de ineficácia do provimento final", pelo art. $461, \S 3^{\circ}$, ou "receio de que uma parte, antes do julgamento da lide, cause ao direito da outra lesão grave e de difícil reparação", nos termos do art. 798). Como ensina ATHOS GUSMÃo CARNEIRO, o prejuízo que pode advir caso o risco venha a se concretizar deve ser considerável, eis que dano mínimo não é suficiente a autorizar a concessão dessas medidas excepcionais ${ }^{152}$.

Esse dano pode ser iminente ou futuro, caso em que o "fundado receio" de que venha a se concretizar se associa à apreensão que a irreparabilidade ou dificuldade de reparação traduzem e deve ser avaliado de acordo com dados concretos, não podendo se limitar ao simples temor ou inconveniência para a parte. Porém, não se exclui que o dano já tenha ocorrido, caso em que a concessão de tutela de urgência servirá para afastar ou minimizar suas consequências.

\footnotetext{
150 “O juízo de verossimilhança ou de probabilidade, como é sabido, tem vários graus, que vão desde o mais intenso até o mais tênue. $\mathrm{O}$ juízo fundado em prova inequívoca, uma prova que convença bastante, que não apresente dubiedade, é seguramente mais intenso que o juízo assentado em mera 'fumaça', que somente permite a visualização de mera silhueta ou contorno sombreado de um direito. Está nesse requisito uma medida de salvaguarda, que se contrapõe à ampliação da tutela antecipatória para todo e qualquer processo de conhecimento. Bem se percebe, assim, que não se trata de tutela que possa ser concedida prodigamente, com mero juízo baseado em 'fumaça de bom direito', como vinha ocorrendo com a ação cautelar inominada". K. WATANABE, Tutela antecipatória cit., p. 8 (arquivo eletrônico).

${ }^{151}$ J. R. S. BEDAQUE, Tutela cautelar cit., p. 231.

152 “Haverá dano quando a permanência do 'status quo', enquanto se sucedem os atos processuais, seja de molde a acarretar ao autor prejuízos de média ou grande intensidade (os prejuízos mínimos não autorizam provimentos de urgência, invasivos da esfera jurídica do demandado) a direito seu, quer direito personalíssimo (como o direito à reputação, à imagem, ao direito-dever de ter sob guarda os filhos ou de visitá-los), quer direitos patrimoniais; dentre estes, de gravidade máxima será o dano consistente na privação de prestações de natureza alimentar, ou no perecimento do próprio direito, caso não concedida a tutela de urgência. O requisito do dano, do 'periculum in mora', é, como vemos, pressuposto comum às medidas cautelares 'stricto sensu' e às AT de que cuida o art. 273, I." Da antecipação cit., p. 32 - grifos do original.
} 
E, no caso da antecipação de tutela, há ainda a possibilidade já rapidamente mencionada de concessão de provimento provisório na hipótese de comportamento desleal por parte do réu ("fique caracterizado o abuso de direito de defesa ou o manifesto propósito protelatório do réu" conforme art. 273, II, do CPC). Trata-se de inovação no sistema processual, destinada a coibir comportamentos indesejados do réu. Para os fins desse inciso, consideram-se abusivos os comportamentos de oposição de exceções e recursos manifestamente infundados, bem como a dedução de requerimentos com o fim único de retardar a solução da demanda ${ }^{153}$.

Concluída a breve exposição sobre conceito e hipóteses de cabimento das tutelas antecipatória e cautelar - que não possuía a pretensão de esgotar o tema, mas apenas de fornecer base para o desenvolvimento de ideias a respeito do regime de recorribilidade das decisões que versam sobre essas formas diferenciadas de tutela - há ainda outros dois aspectos que merecem ser abordados, pois possuem impacto na necessidade de recurso de apreciação imediata nesses casos.

\subsubsection{SEgUE: DO PERIGO DE IRREVERSIBILIDADE DO PROVIMENTO E DA AUSÊNCIA DE CONTROVÉRSIA SOBRE PEDIDO OU PARTE DO PEDIDO}

O primeiro diz respeito ao perigo de irreversibilidade do provimento antecipatório, que, nos termos do art. 273, §2 $2^{\circ}$, do Código de Processo Civil, impede a respectiva concessão ("Não se concederá a antecipação da tutela quando houver perigo de irreversibilidade do provimento antecipado"). Trata-se de hipótese atípica na qual se contrapõem, de um lado, a urgência na concessão do provimento e, de outro, a sua irreversibilidade.

A redação do inciso abre margem a duas ordens de interpretações: de um lado, pode-se entender, com MARINONI, que a lei foi precisa ao mencionar a irreversibilidade do provimento, e não dos efeitos práticos do provimento, sendo que esta não seria impedimento à concessão de tutela antecipada, mas somente aquela ${ }^{154}$. De outro,

\footnotetext{
${ }^{153}$ Cf. L. G. MARINONI, A antecipação da tutela, 6 a edição, revista e ampliada, São Paulo, Malheiros, 2000, pp. 158-160.

${ }^{154}$ Para melhor compreensão do raciocínio do processualista paranaense, vide seu $A$ antecipação cit., pp. 171-178, do qual destaca-se os seguintes trechos, extraídos das pp. 171 e 172-173, respectivamente: "Não seria preciso dizer que 'irreversibilidade do provimento' e 'irreversibilidade dos efeitos fáticos do
} 
há quem, como Athos Gusmão CARneIro, sustente que por "irreversibilidade do provimento" deve-se ter "irreversibilidade dos efeitos do provimento"155.

Seja qual for o posicionamento adotado, contudo, entende-se que deve prevalecer a proteção ao direito invocado, obviamente desde que observados os demais requisitos para a concessão do provimento antecipatório. Nesse sentido, José RoBERTO dos Santos Bedaque ${ }^{156}$, Athos Gusmão Carneiro ${ }^{157}$ e Luiz Guilherme Marinoni ${ }^{158}$, apenas para citar alguns.

Substancialmente de acordo está ORESTE LASPRO, que pontua ainda a necessidade de, nesses casos, (i) antes de se decidir pela concessão da tutela antecipada, verificar a necessidade do provimento, que só deverá ser deferido se não houver outra forma de preservar o direito; (ii) garantir o contraditório à parte que será prejudicada; (iii) investigar quem deu causa à situação de urgência; e, por último, (iv) observar o princípio da proporcionalidade ${ }^{159}$

provimento' são coisas que não se misturam, se não fosse a confusão, que sempre reinou nos tribunais, entre a estrutura e a função da tutela antecipatória." Para ele, "[a] provisoriedade da tutela antecipatória deve ser entendida como a sua incapacidade de definir a controvérsia, por sua absoluta falta de idoneidade para a declaração ou, em outros termos, para a produção de coisa julgada material. A satisfatividade da tutela antecipatória, e mesmo a eventual irreversibilidade dos efeitos fáticos desta tutela, não é contraditória com a sua estrutura. Em outras palavras, nada impede que uma tutela que produza efeitos fáticos irreversíveis seja, do ponto de vista estrutural, provisória, vale dizer, incapaz de dar solução definitiva ao mérito."

155 'Vale, aqui, uma observação: a 'irreversibilidade' não se refere propriamente ao 'provimento' antecipatório, mas sim aos efeitos do provimento. O provimento, em si mesmo, como decisão judicial passível de recurso e que pode ser revogada ou modificada a qualquer tempo (art. $273, \S 4^{\circ}$ ), é eminentemente reversível." Da antecipação cit., p. 81.

${ }^{156}$ Cf. Tutela cautelar cit., p. 384.

${ }^{157}$ Cf. Da antecipação cit., p. 85

158 “Admitir que o juiz não pode antecipar a tutela, quando a antecipação é imprescindível para evitar um prejuízo irreversível ao direito do autor, é o mesmo que afirmar que o legislador obrigou o juiz a correr o risco de provocar um dano irreversível ao direito que justamente lhe parece mais provável". A antecipação cit., p. 177 - grifo do original.

159 "Evidentemente que a concessão da tutela antecipada irreversível, além de excepcional, deve se sujeitar ao preenchimento de determinadas condições, afora o preenchimento dos requisitos impostos a qualquer hipóteses de antecipação de tutela. Em primeiro lugar, deve ser respeitado o princípio da necessidade, isto é, o julgador, deve estar absolutamente seguro de que não existe outra forma de assegurar o direito do requerente se não por meio daquele provimento cujos efeitos são irreversíveis. Em segundo lugar, a tutela antecipada nesses casos somente deve ser deferida depois de efetivado o contraditório. (...) Em terceiro lugar, deve ser analisado quem deu causa à situação de urgência. De fato, é cada vez mais comum os requerente irem a juízo no último instante de modo a querer obrigar o julgador à concessão da tutela de urgência, muitas vezes com efeitos irreversíveis, sem possibilitar à parte contrária um contraditório pleno. Nestes casos, não pode o Estado Jurisdição ratificar essa conduta (...). Finalmente, em quarto lugar, vem a regra resultante da proporcionalidade, isto é, haverá um juízo de ponderação dos valores em jogo, isto é, terá o juiz de decidir entre a preservação do direito de requerente por via da tutela antecipada e a não invasão da esfera de direitos do requerido, indeferindo, pois, o pedido". Devido processo legal e a irreversibilidade da antecipação dos 
$\mathrm{Na}$ linha do que se expôs, por se tratar de situação-limite no processo civil, em que a concessão do provimento pode se mostrar irreversível mas, em contrapartida, seu indeferimento pode gerar dano irreparável ou de difícil reparação à parte, parece claro que a observância do contraditório a que se aludiu acima deve ser interpretada ampliativamente, estendendo-se à parte prejudicada pela decisão a oportunidade de impugná-la imediatamente.

Em segundo lugar, impende observar a técnica prevista no art. $273, \S 6^{\circ}$, do Código de Processo Civil, que permite a antecipação de tutela em caso de ausência de controvérsia sobre pedido ou parte do pedido (“A tutela antecipada também poderá ser concedida quando um ou mais dos pedidos cumulados, ou parcela deles, mostrar-se incontroverso"). Aqui, está-se diante da possibilidade de julgamento parcial do mérito, de sorte que se retoma parcialmente a discussão já desenvolvida no tópico 2.4 a respeito do tipo de pronunciamento judicial proferido e, via de consequência, do recurso cabível para impugná-1o ${ }^{160}$.

Como se verificou, é inerente à própria concepção de tutelas de urgência a sua provisoriedade, porque, em razão da sua estrutura, deverão ser necessariamente substituídas por outro provimento que tenha aptidão para formar coisa julgada ${ }^{161}$. Diretamente associada a esse aspecto está a sua revocabilidade, tanto que as tutelas antecipatória e cautelar podem ser revogadas até mesmo pelo próprio órgão que as havia deferido inicialmente.

A mais óbvia razão pela qual decisão que concede ou denega tutela de urgência deve se sujeitar a recurso imediato é a circunstância de que, pela sua própria natureza, é proferida em situações limite e, sendo assim, o erro de avaliação pode acarretar

efeitos da tutela jurisdicional in L. G. MARINONI (coord.), Estudos de direito processual civil - Homenagem ao Professor Egas Dirceu Moniz de Aragão, $1^{a}$ edição, São Paulo, Revista dos Tribunais, 2005, pp. 271-272.

160 "Na realidade, a figura tratada pelo $\S 6^{\circ}$ do art. 273 representa hipótese de decisão final de parte da causa, fundada em cognição exauriente e com conteúdo idêntico ao da sentença (mas apenas parcial). Seu fundamento não se encontra nem na proteção contra a demora (art. 273, I), nem em eventual sanção ao réu de má-fé (art. 273, II). Também não se trata de proteção provisória satisfativa, que é a nota típica da antecipação de tutela. Propriamente, a decisão aqui cogitada é final, correspondendo àquela que o magistrado adotaria, ao final, como sentença, se o objeto do processo estivesse limitado apenas a este aspecto incontroverso.” S. C. ARENHART, A antecipação de tutela e as alterações da lei 10.444/2002 in L. G. MARINONI (coord), Estudos de direito processual civil - Homenagem ao Professor Egas Dirceu Moniz de Aragão, 1 a edição, São Paulo, Revista dos Tribunais, 2005, p. 283. No mesmo sentido, vide L. G. MARINONI, A antecipação cit., pp. 151158, esp. p. 152.

${ }^{161}$ Cf. O. N. S. LASPRO, Devido processo cit., p. 270. 
prejuízos irreversíveis, graves ou de difícil reparação para a parte não favorecida pelo pronunciamento judicial. Essa circunstância fica ainda mais evidente diante da possibilidade de o juiz conceder tutela antecipatória em situação de irreversibilidade, como se aventou.

E relacionado a esse fator há ainda a questão estrutural das tutelas de urgência, imaginadas para enxertar dinamismo no processo a cognição exauriente: se, pela sua função e estrutura, se entende que as tutelas de urgência devem poder ser revogadas a qualquer tempo, é preciso conferir às partes mecanismos para que façam valer essa prerrogativa de tentar cassar ou obter provimento jurisdicional nesse sentido.

Essas conclusões não se alteram pela circunstância de serem as decisões que versam sobre tutelas de urgência suscetíveis de modificação ou revogação pelo próprio juiz que as proferiu (art. 273, $\S 4^{\circ}$, art. $461, \S 6^{\circ}$ e art. 807, todos do Código de Processo Civil). Com efeito, o sistema processual prevê duplo controle sobre essas medidas, sendo a possibilidade de revisão do provimento pelo seu prolator limitada em razão da preclusão de questões de que se tratará em profundidade no próximo capítulo.

Assim, adiantando-se o raciocínio que na sequência se exporá, evidencia-se que a matéria que poderia ser objeto do agravo contra a decisão interlocutória a respeito de tutela de urgência não poderá ser de ofício ou a requerimento da parte revista pelo juiz prolator sem a interposição do recurso ou sem que tenham sobrevindo novas circunstâncias a justificar o reexame ${ }^{162}$.

\subsubsection{DAS INTERVENÇÕES DE TERCEIROS: O EXEMPLO DA ASSISTÊNCIA}

Como já se mencionou, outra situação em que entende não se poder prescindir de recurso em face de decisão interlocutória diz respeito aos pedidos de intervenções de terceiro. Dentre estas, elegeu-se a assistência para ser tratada em maior profundidade, apenas para facilitar a visualização dos aspectos que se entende relevantes.

\footnotetext{
${ }^{162}$ Assim pensa L. G. MARINONI: "Esse sistema binário para bem funcionar, deve supor que os pressupostos para a revogação-modificação da tutela nada têm a ver com a matéria que pode ser posta no agravo. As razões que permitem a revogação ou a modificação da tutela, quando não interposto o agravo, são as 'novas circunstâncias', vale dizer, são 'outras razões"”. A antecipação cit., p. 166.
} 
Sem pretender esgotar o assunto, justifica-se a atenção na medida em que a intervenção é que abre a porta para que o terceiro venha a participar ${ }^{163}$, segundo as regras e condições que, de acordo com a lei, são adequadas à luz da sua situação legitimante específica $^{164}$.

De modo geral, as intervenções de terceiros se podem classificar em voluntárias e coatas, conforme ensina CÂNDIDO DINAMARCO ${ }^{165}$.

As primeiras "têm a finalidade de obstar à formação e precedente incômodo ao terceiro e de propiciar-lhe um julgamento favorável já no processo pendente inter alios". Os terceiros sujeitos a esses "inconvenientes reflexos" podem intervir no processo "opondo às pretensões do demandante e do demandado a sua própria (oposição) ou oferecendo ajuda a uma das partes (assistência)"166. Já as intervenções de terceiros coatas (nomeação à autoria, denunciação à lide e chamamento ao processo) são provocadas pela parte "com o fito de extrair do processo uma utilidade maior" 167.

Dois são, portanto, os fatores que justificam a necessidade de recurso para impugnar imediatamente decisão que verse sobre intervenção de terceiros. De um lado, a oponibilidade da coisa julgada ao terceiro cuja intervenção tenha sido incorretamente indeferida e, de outro, razões de economia processual, associadas ao inconveniente da declaração de nulidade de todo o processo.

Para ilustrar, toma-se como exemplo a assistência, intervenção adesiva realizada com o escopo de ajudar uma das partes. O Código de Processo Civil prevê duas

\footnotetext{
163 “[A]s hipóteses de intervenção de terceiros são temperamentos do princípio da singularidade, os quais se justificam porque a sentença, desde que existe no mundo jurídico, provoca implicações em relações jurídicas de pessoas que não são exclusivamente autor e réu. Isto ocorre porque as relações jurídicas não existem isoladas no mundo do direito, elas se inter-relacionam e sua complexidade determina, às vezes, influência recíproca”. V. Greco FilHO, Da Intervenção de Terceiros, 3ª edição, São Paulo, Saraiva, 1991, p. 71.

${ }^{164}$ Nesse sentido, T. ALVIM: "Pode-se, com segurança, dizer que a coisa julgada material não alcança terceiros, na exata medida em que a solução judicial é proferida em lide que não lhe diz respeito. Com isso, não se está, porém, significando que as decisões judiciais não alcançam terceiros. O que não os atinge é a imutabilidade do comando delas emergente, a coisa julgada material. Na razão de poderem os terceiros ser atingidos pela decisão judicial (não pela coisa julgada material), confere o direito positivo, a eles, a possibilidade de intervir em processo alheio, ou seja, toda vez que, de qualquer forma, seja, ou possa esse terceiro vir a ser afetado em sua esfera jurídica pela decisão judicial ou, até mesmo, em certos casos, pela fundamentação desta, há possibilidade de que intervenha no processo onde essa decisão virá a ser prolatada." O direito processual de estar em juizo, $1^{\text {a }}$ edição, São Paulo, Revista dos Tribunais, 1996, pp. 186.

${ }^{165}$ Cf. Intervenção de terceiros, $5^{\mathrm{a}}$ edição, São Paulo, Malheiros, 2009, pp. 19-22.

${ }^{166}$ C. R. DinAmarco, Intervenção de terceiros cit., p. 21 - grifos do original.

${ }^{167}$ C. R. DINAMARCO, Intervenção de terceiros cit., p. 22.
} 
modalidades de assistência: simples e litisconsorcial. Ambas estão fundadas primariamente no interesse jurídico de um terceiro em que a sentença seja favorável a uma das partes.

Esse interesse deve ser juridicamente relevante ${ }^{168}$, não podendo ser meramente econômico, ou simples interesse de fato ${ }^{169}$. Isso porque, ao final do processo, o assistente não poderá mais discutir a justiça da decisão ${ }^{170}$, a teor do art. 55 do Código de Processo Civil, ressalvadas as exceções dos seus dois incisos. No caso da assistência simples, o interesse jurídico é o único fator que justifica a intervenção do terceiro ${ }^{171}$.

Já na assistência litisconsorcial, o assistente atua para evitar a prolação de decisão com força de coisa julgada ${ }^{172}$ sobre a sua relação com o adversário do assistido ${ }^{173}$.

168 "Na assistência simples, o terceiro, para intervir ad adiuvandum, deve ter interesse jurídico - e a conseqüente legitimação ad agendum - que seja suficiente a justificar sua intervenção e pedido. Trata-se, porém, de legitimação acessória, secundária ou dependente, de sujeito processual subordinado, que 'atuará...como auxiliar da parte principal', com poderes idênticos ao desta e acabando sujeito aos efeitos da sentença ". J. FredERICO MARQUES, Manual de direito processo civil, v. 1, $1^{\text {a }}$ edição, Campinas, Bookseller, 1997, pp. 369-370.

169 “'O interesse há de ser jurídico. Não basta, por exemplo, que a perda da demanda pela parte que outrem quer assistir, diminua o patrimônio do vencido, que é devedor ao terceiro. Aliter, se o bem, que é objeto da lide, teria de ser vendido ao terceiro, em virtude de pré-contrato, ou mesmo da regra jurídica sobre preferência ou opção. O que é preciso é que a sentença proferida entre as partes atinja ou possa atingir direito, pretensão, ou ação, ou exceção, do terceiro. Não seria interesse jurídico o de simples fato, porque então seria interesse apenas econômico. Nem parente pode pretender assistência em ação alheia, porque havia repercussão moral no tocante à família”. F. C. PONTES DE MiRANDA, Comentários ao Código de Processo Civil, tomo II, Rio de Janeiro, Forense, 1974, p. 56.

${ }^{170}$ Assim o ensinamento de E. T. LIEBMAN: "Condição para a intervenção é, pois, o interêsse do terceiro no resultado do processo. O interesse deve ser de caráter jurídico, porque deve tratar-se de um dos casos em que a sentença proferida entre as partes pode afetar a relação jurídica de que o terceiro é titular. Essa possibilidade deriva da interdependência das relações jurídicas a que deram vida os vários sujeitos, e, portanto, do nexo de prejudicialidade que pode intercorrer entre a relação controversa, deduzida em juízo pelas partes, e a relação existente entre uma das partes e o terceiro (...). O interesse que autoriza a intervenção não pode ser, portanto, de mero fato, isto é, de caráter prático, econômico ou moral, mas, antes, jurídico, significando que a eficácia da sentença a prolatar-se possa refletir-se a benefício ou em prejuízo de terceiro, com influência sôbre a existência ou sôbre as modalidades de suas próprias relações jurídicas ". Nota de rodapé in G. ChIOvenda, Instituições de Direito Processual Civil, v. 2, 2ª edição com notas de Enrico Tullio Liebman, trad. da 2a edição italiana J. Guimarães Menegale, São Paulo, Saraiva, 1965, p. 239.

171 “O que justifica o ingresso do assistente simples no processo é o seu interesse, seja econômico, seja moral, mas há de ser sempre jurídico no sentido de a ordem jurídica ter emprestado a esse interesse, econômico ou moral, relevância constante da alusão feita pela lei, caracterizando-o como sendo interesse jurídico, ou, contida por compreensão, no sistema.” J. M. Arruda Alvim Netto e T. A. A. Pinto, Assistência Litisconsórcio, São Paulo, Revista dos Tribunais, 1986, p. 13.

172 "Há, porém, outra espécie ou forma de assistência, denominada litisconsorcial, em que o interveniente atua para evitar decisão, com força de res iudicata, que posa influir na relação jurídica entre ele e o adversário do assistido”. J. FREDERICO MARQUES, Manual cit., v. 1, pp. 369/370.

173 "Em suma: o assistente litisconsorcial é aquele que mantém relação jurídica própria com o adversário da parte assistida e que assim poderia desde o início da causa, figurar como litisconsorte facultativo. Seu ingresso posterior, como assistente, assegura-lhe, assim, o status processual de litisconsorte". H. THEODORO JR., Curso de direito processual civil, v. 1, 50ª edição comemorativa, Rio de Janeiro, Forense, 2009, p. 144. 
Nesse caso, o assistente possui interesse tal que poderia atuar sozinho em demanda própria, sendo então considerado litisconsorte do assistido ${ }^{174}$.

Essas breves considerações evidenciam que, se o principal fundamento da assistência é a economia processual consubstanciada na possibilidade de o terceiro influenciar no teor da sentença que será proferida e, em contrapartida, não poder mais discutir seu acerto em processo posterior, ele deve por óbvio poder participar da relação processual.

Mas o raciocínio se aplica também para outras formas de intervenção de terceiros, "haja vista que o dano que emerge de tais decisões é presente e atual, e a reiteração do pedido denegado gera o risco de que todo o processo seja anulado, ab initio", como bem ressaltou HeITOR SiCA ${ }^{175}$.

\footnotetext{
174 “Já diversamente, na assistência litisconsorcial, os efeitos da sentença entre as partes principais afetam virtual e inexoravelmente a relação jurídica do assistente litisconsorcial, com o adversário de assistido, se este perder a ação, o que significa que o assistente litisconsorciado também a terá perdido, e, tal ocorrerá se não tiver interessado no processo, igualmente". J. M. ARruda Alvim NetTo e T. A. A. Pinto, Assistência cit., p. 14.

${ }^{175}$ Recorribilidade das interlocutórias e reformas processuais: novos horizontes do agravo retido in NERY JR., Nelson, WAmbier, TERESA ARRUdA Alvim (coords.), Aspectos polêmicos e atuais dos recursos cíveis e de outros meios de impugnação às decisões judiciais, v. 8, São Paulo, Revista dos Tribunais, 2005, p. 189.
} 


\section{RELAÇÃo ENTRE O AGRAVO E A PRECLUSÃo de QUESTÕES}

O estudo da preclusão é notadamente marcado pela influência de CHIOVENDA $^{176}$, que operou tentativa de definir seu conceito ${ }^{177}$, sistematizando as hipóteses em que ocorreria ${ }^{178}$ e diferenciando-o de outras ideias (como a de coisa julgada ${ }^{179}$, por exemplo) ${ }^{180}$, no início do século XX. Em seus estudos, encontra-se a noção de preclusão como a impossibilidade de exercer determinada faculdade processual, que poderia decorrer (i) da inobservância do prazo para a prática do ato; (ii) da prática anterior de ato incompatível; ou (iii) da própria prática do ato.

\footnotetext{
${ }^{176}$ Foram publicados diversos escritos a respeito do tema, que demonstram a evolução do pensamento de G. ChIOvenda. No entanto, tendo em vista o objetivo deste trabalho, a consulta se focou na obra Instituições de Direito Processual Civil, considerada o último estágio da evolução do pensamento do jurista italiano a respeito do assunto.

177 "Direi, por consequência, para esclarecer onde necessário o meu pensamento, e ao mesmo tempo para precisar quais possam ser os limites cuja inobservância carreia a perda de uma faculdade processual, que entendo por preclusão a perda, ou extinção, ou consumação de uma faculdade processual que sofre pelo fato: a) ou de não se haver observado a ordem prescrita em lei ao uso de seu exercício, como os prazos peremptórios, ou a sucessão legal das atividades e das exceções; b) ou de se haver realizado uma atividade incompatível com o exercício da faculdade, como a propositura de uma exceção incompatível com outra, ou a realização de um ato incompatível com a intenção de impugnar uma sentença; c) ou de já se haver validamente exercido a faculdade (consumação propriamente dita). G. CHIOvENDA, Instituições de Direito Processual Civil, v. 3, $1^{\mathrm{a}}$ edição com notas de Enrico Tullio Liebman, trad. da $2^{\mathrm{a}}$ edição italiana J. Guimarães Menegale, São Paulo, Saraiva, 1945, pp. 220-221.

178 “Coligi e reuni sob essa observação e essa denominação numeroso casos (e não são todos) nos quais esse expediente se acha aplicado pela lei. São casos variadíssimos, seja pela faculdade processual a que se refere cada um deles, seja pelos efeitos que pode produzir a preclusão do exercício dessa faculdade; mas têm todas, em comum, este elemento, em que, para mim, se concentra a essência da preclusão, a saber, a perda, ou extinção, ou consumação, ou como quer que se diga, se uma faculdade processual pelo só fato de se haverem atingido os limites prescritos ao seu exercício.” G. CHIOVENDA, Instituições cit., v. 3, p. 220.
}

179 "Mais não é preciso para demonstrar como essa preclusão de questões nada tem que ver com a coisa julgada. As duas coisas só apresentam isto de comum: que em todos esses casos há questões que não se podem mais suscitar, ao passo que, segundo salientamos, a coisa julgada também repousa sobre a preclusão das questões." G. ChIOvEndA, Instituições de Direito Processual Civil, v. 1, $1^{\mathrm{a}}$ edição com notas de Enrico Tullio Liebman, trad. da $2^{\mathrm{a}}$ edição italiana J. Guimarães Menegale, São Paulo, Saraiva, 1942, p. 525. E salienta adiante uma grande diferença entre um e outro: "a preclusão tem eficácia unicamente para o processo em que ocorre; num outro processo, pode-se livremente suscitar de novo." G. ChIOvEndA, Instituições cit., v. 1, p. 526. Convém, contudo, ressaltar, que o processualista italiano utiliza o termo "preclusão de questões" para se referir à preclusão de um modo geral, e não à preclusão dirigida à atividade do juiz, como neste trabalho.

180 “Por si mesma, pois, a preclusão não produz efeito a não ser no processo em que advém. Assim já observamos que uma coisa é a simples preclusão duma questão, a qual, por si só, não opera senão no processo em que se verifica, a exemplo do que ocorre com a questão de competência; outra coisa é o caso julgado que decorre da preclusão da questão de mérito e se destina a produzir seus efeitos nos processos futuros (supra, vol. I, $\mathrm{n}^{\circ}$ 117); outra, ainda, é a confissão que produz efeito mesmo nos processos futuros (art. 1.356); outra, enfim, é a ficta confessio, que por simples preclusão, produz efeito unicamente no processo em que ocorre (supra, $\mathrm{n}^{\text {os }} 269$ e 270).” G. CHIOVENDA, Instituições cit., p. 222. 
Não obstante seus esforços e os daqueles que lhe sucederam, tanto na Itália como no Brasil, a expressão "preclusão" designa fenômeno(s) a respeito de cuja natureza jurídica não há consenso na doutrina. Há quem sustente se tratar de sanção processual ${ }^{181}$, princípio, fato processual, instituto ou técnica ${ }^{182}$.

No que concerne ao seu alcance - especialmente à possibilidade de a preclusão recair também sobre as atividades do juiz - igualmente há dissonância entre os doutrinadores, conforme se exporá no tópico seguinte.

Para os fins deste trabalho - que não se propõe a estudar o fenômeno da preclusão em profundidade, mas apenas a sua relação com a proposta de modificar o regime de recorribilidade das decisões interlocutórias contida no projeto de novo Código de Processo Civil -, parte-se da premissa de que a preclusão deve ser encarada como mecanismo genérico de limitação à atividade dos sujeitos processuais ${ }^{183-184}$.

A partir disso, passar-se-á a análise da chamada preclusão de questões, seus contornos no direito brasileiro, passando pela relação do instituto da preclusão com o

${ }^{181}$ Ainda que sui generis: "A preclusão tem a natureza jurídica de uma penalidade sui generis (restrita)
consistente no impedimento da prática de um ato processual, em virtude do decurso do prazo para fazê-lo ou
do exercício de faculdade com ele incompatível". Cf. J. B. LOPES, Breves considerações sobre o instituto da
preclusão, obtido em www.rtonline.com.br, originalmente publicado em Revista de Processo, 23:1981.

Aliás, curioso notar que o próprio G. CHIOvENDA, embora faça referência à ideia de poena preclusi para explicar a denominação que deu ao fenômeno, afirma que não tem caráter de sanção: "Todo processo, uns mais, outros menos, e da mesma forma o nosso processo, com o fim de assegurar precisão e rapidez ao desenvolvimento dos atos judiciais, traça limites ao exercício de determinadas faculdades processuais, com a consequência de que, além de tais limites, não se pode usar delas. Emprestei a essa consequência o nome de 'preclusão', extraído de uma expressão das fontes que se empregava, precisamente com o significado que lhe dou, 'poena praeclusi' do direito comum, ressalvando-se que, no direito moderno, naturalmente se prescinde da ideia de pena." Instituições cit., v. 3, p. 220.

182 “No direito processual moderno, a preclusão é apenas o mecanismo que provoca a passagem de um estágio processual para outro, preservando a firmeza e inatacabilidade dos atos processuais já consumados. Com a preclusão simplesmente se fecha, pela superveniência de nova etapa processual, o estágio processual anterior." H. THEODORO JR., A preclusão no processo civil, obtido em www.rtonline.com.br, originalmente publicado em Revista dos Tribunais, 794: 2001.

Para J. R. S. BEDAQUE, "é técnica voltada ao rápido andamento da relação processual, mediante a imposição de restrições temporais e lógicas à prática dos atos do procedimento. A razão de ser e a finalidade dos mecanismos preclusivos estão ligadas ao interesse público, consistente em assegurar a simplificação, a rapidez e a eficiência do instrumento." Efetividade cit., p. 128.

${ }^{183} \mathrm{Na}$ esteira do afirmado por H. SICA, para quem se pode partir da premissa de que "todo sistema processual deve, em alguma medida, restringir a atividade das partes e limitar a revisão das decisões incidentais" (grifo do original). Preclusão cit., p. 52.

${ }^{184}$ Não muito diferente é a definição apresentada por J. R. S. BEDAQUE, para quem a preclusão "visa a possibilitar o próprio desenvolvimento dele [processo], estabelecendo limites à prática de atos pelas partes e à discussão de questões processuais, a fim de que, mediante impulso oficial, se chegue ao exame da situação substancial, com a concessão ou a denegação da tutela jurisdicional”. Efetividade cit., p. 128. 
sistema de procedimento rígido e por breves considerações a respeito do tratamento da matéria no direito italiano para, após breve análise do conteúdo das alterações atinentes à matéria no Projeto de novo CPC, apresentar nossas considerações de cunho crítico e conclusivo acerca da temática.

\subsection{PRECLUSÃo PARA AS PARTES E PARA O JUIZ: DOIS FENÔMENOS DISTINTOS}

Como visto, é possível afirmar que a preclusão é instrumento de controle da marcha processual que visa a impedir retrocessos, de modo que, uma vez que o processo tenha avançado à fase subsequente, não se tolera o retorno à anterior ${ }^{185}$, especialmente importante no sistema brasileiro de procedimento rígido. Com isso, responde-se também a imperativo de limitação temporal da duração do processo ${ }^{186}$, impedindo que se estenda indefinidamente.

Estabelecido este ponto de partida, tem-se que, apesar da já mencionada divergência doutrinária, a palavra "preclusão" tem sido utilizada para designar tanto a limitação à atividade dos sujeitos parciais consistente na perda da faculdade de praticar determinado ato - decorrente da inércia, da prática anterior de ato incompatível ou da própria prática do ato -, quanto à atuação do juiz, vedando a que decida novamente questão que já tenha sido por ele próprio apreciada - neste caso, por vezes acompanhada do complemento pro judicato.

Ocorre que, na realidade, como aponta HEITOR SICA ${ }^{187}$, a preclusão dirigida à atividade das partes é fenômeno distinto da preclusão de questões, ainda que ambos

\footnotetext{
185 "O instituto da preclusão tem imensa relevância no sistema brasileiro de procedimento rígido. Ele dá apoio às regras que regem a ordem sequencial de realização dos atos do procedimento e sua distribuição em fases - fazendo-o mediante a imposição da perda de uma faculdade ou de um poder em certas situações." C. R. Dinamarco, Instituições de Direito Processual Civil, v. 2, $1^{\text {a }}$ edição, São Paulo, Malheiros, 2001, pp. 451-452.

${ }^{186}$ Cf. J. R. S. BEDAQUE, para quem "o instituto da preclusão encontra sua razão de ser, portanto, na inadmissibilidade de o método estatal de solução dos litígios desenvolver-se aleatoriamente, segundo as opções ideológicas de seu condutor." Efetividade cit., p. 129. E, mais adiante: "para fixarmos os contornos da preclusão e de suas espécies, devemos considerar que se trata de mecanismo destinado a impulsionar o processo, evitando retornos a fases já superados (sic) do procedimento - o que comprometeria a segurança e a celeridade do instrumento." Efetividade cit, p. 129.

C. R. DinAMARCo chega a afirmar que a preclusão "é um dos grandes responsáveis pela aceleração processual". Instituições cit., v. 2, p. 452.

${ }^{187}$ Preclusão cit., p. 91.
} 
possuam a mesma finalidade e fundamento. A distinção decorre fundamentalmente do tipo de posições jurídicas assumidas no processo pelas partes, que defendem interesses próprios, e pelo juiz, que defende o interesse público ${ }^{188}$, respectivamente. Sintetizando, as partes podem optar por deixar de praticar determinado ato, mas o juiz não pode se abster de exercer sua função no processo.

A preclusão para as partes - que não é o objeto deste estudo e que será tratada por vezes apenas tangencialmente - se divide classicamente em três espécies: temporal, lógica e consumativa. A primeira ocorre quando a parte, normalmente sujeita a prazos próprios (também chamados preclusivos), deixa de realizar determinado ato no prazo designado para tanto ${ }^{189}$.

A preclusão lógica se verifica, independentemente de previsão legal ${ }^{190}$, quando a parte se vê impossibilitada de praticar certo ato em razão de ter agido, em momento anterior, de maneira que com ele não se compatibiliza ${ }^{191}$.

Por fim, a preclusão consumativa corresponderia à impossibilidade de a parte praticar novamente ato que já tenha praticado ${ }^{192}$, cabendo ressaltar que a existência dessa modalidade de preclusão para as partes tem sido questionada em recentes estudos ${ }^{193}$, que de modo geral pregam cautela na interpretação do alcance do instituto, especialmente no tocante à diferenciação entre a preclusão consumativa (que impede a parte de repraticar

\footnotetext{
188 "Diante dessa discrepância de interesses atendidos pelos sujeitos do processo ao nele atuarem, parece no mínimo lógico e natural que o tratamento legal dado às posições jurídicas por eles ocupadas seja diverso." $\mathrm{H}$. V. M. SicA, Preclusão cit., p. 107

189 "Não cumprido o ato no tempo preestabelecido, o fenômeno da preclusão temporal impede que elas [as partes] possam realizá-lo depois e obter os resultados desejados". C. R. DinAMARCO, Instituições cit, v. 2, p. 548.

${ }^{190}$ De acordo com H. V. M. SICA, que também cita como exemplos de preclusão lógica expressamente previstos pelo Código de Processo Civil as disposições dos arts. 177, caput, e 503. Preclusão cit., p. 149.

${ }^{191}$ Cf. lição de A. C. MARCATO: "preclusão lógica significa a impossibilidade de praticar a parte determinado ato pelo fato de ser ele incompatível com outro anteriormente consumado". Preclusões: limitação ao contraditório?, obtido em www.rtonline.com.br, originalmente publicado em Revista de Processo, 17:1980, pp. 105 e seguintes, pp. 2-3 (arquivo eletrônico).

${ }^{192}$ Para J. R. S. BEDAQUE, a preclusão consumativa é "definida como perda da faculdade processual já validamente exercida" (grifo do original). O processualista alerta ainda para a circunstância de que, para a correta compreensão do fenômeno da chamada preclusão consumativa "não se pode prescindir da validade do ato praticado no exercício de determinada faculdade ou no cumprimento de algum ônus" (grifo do original). Efetividade cit., p. 146.

${ }^{193}$ Assim, por exemplo, F. F. S. CAIS, Preclusão e a instrumentalidade do processo, dissertação (mestrado em Direito Processual), Faculdade de Direito - Universidade de São Paulo, São Paulo, 2006, p. 24.
} 
determinado ato) e a possibilidade de regularização de aspecto formal do ato praticado ${ }^{194-}$ 195

\section{LIEBMAN $^{196}$ acena para a existência de ainda outro tipo preclusão dirigida às} atividades das partes, nas situações em que, mesmo transcorrido o prazo para que se pronunciassem, o tribunal aceita sua (a rigor, intempestiva) manifestação, desde que o processo ainda não tenha seguido para a fase seguinte. A esse fenômeno, CÂNDIDO DINAMARCO chamou preclusão mista - vez que consiste na associação do transcurso do prazo com outro fator, o prosseguimento do processo -, que não permite, de todo modo,

\footnotetext{
${ }^{194}$ Nesse sentido, sustenta H. V. M. SICA que a parte que já tenha praticado determinado ato poderia, até o final do prazo assinalado para a sua prática, emendá-lo, ao fundamento de que "vedar à parte a emenda do ato quando ainda não transcorreu o prazo a ele assinalado representa uma sanção injusta àquele que militou em favor da celeridade processual, o qual (sic), em última instância, é de interesse público e inclusive inspira o instituto da preclusão. Se uma das principais finalidades da preclusão é fazer o processo caminhar com maior rapidez, não é aceitável que esse instituto sirva justamente para punir o agente que se antecipou." Preclusão cit., p. 135.
}

E continua: "estamos convictos de que a emenda a qualquer ato processual validamente praticado, desde que dentro do prazo que a lei the destina, é plenamente viável. E, se assim é, a conclusão é, a rigor, a de que a preclusão consumativa não encontra amparo ou previsão legal, e os prazos processuais são a principal limitação da parte para emendar atos que tenha praticado anteriormente." Preclusão cit., p. 136. Obviamente, o raciocínio do autor tem por pressuposto que ainda não se tenha extinguido o prazo para a prática do ato, pois, nesta hipótese, a limitação à emenda decorreria de preclusão temporal e não de preclusão consumativa.

É essa também a opinião de J. R. S. BEDAQUE, para quem, "Se no ato verifica-se a existência de defeito, a parte pode saná-lo se ainda não esgotado o prazo para sua realização. Mesmo porque, se não eliminado o defeito, o ato certamente não produzirá os efeitos a ele inerentes. Não se justifica, portanto, impedir a regularização, se realizada no prazo. Conclusão contrária implica apenar duplamente a parte, além de reduzir o tempo concedido para a prática regular do ato apenas por haver ela agido antes do termo final. Não se pode extrair desse comportamento renúncia ao período faltante, pois a antecipação não é ato incompatível com a regularização ou complementação realizada antes do encerramento do prazo." Efetividade cit., pp. 146-147.

${ }^{195}$ Explica H. THEODORO JR. que existe diferença entre a preclusão consumativa e a "regularização de vícios do ato praticado, admissível desde que atendidos os princípios que regem o sistema das nulidades processuais", assim resumindo seu raciocínio: "Preclusão consumativa é, pois, a perda da faculdade de praticar o ato. Consumado seu exercício, não há como repeti-lo. Fenômeno diverso consiste na possibilidade de corrigir vícios do ato processual." A preclusão cit.

196 "Por preclusão se entende a perda ou extinção do direito de realizar um ato processual em virtude: a) do decurso do prazo; b) da falta do exercício no momento oportuno, quando a ordem legalmente estabelecida para a sucessão das atividades processuais implicar uma consequência assim grave". E. T. LIEBMAN, Manual de Direito Processual Civil, trad. Cândido Rangel Dinamarco, v. 1, $3^{\text {a }}$ edição, São Paulo, Malheiros, 2005, p. 302.

Em nota, C. R. DinAMARCo explicita o raciocínio do autor: "Nessa hipótese, de certa maneira próxima à da preclusão temporal, não é levado em conta somente o decurso do tempo para extinguir-se a faculdade ou o poder processual, é preciso que, além de passado o prazo, tenha sido praticado ato subsequente, de modo que (máxime no sistema brasileiro de procedimento rígido), a pratica do ato omitido significaria um retrocesso incompatível com o sistema" Manual cit., p. 302. 
que eventual prática do ato a destempo pela parte venha a ser aceita se acarretar retrocesso na marcha processual ${ }^{197}$.

Por outro lado, a mera existência de preclusão para o juiz é questionada por parte da doutrina, que não aceita a existência desse fenômeno, conforme se passará a expor no tópico seguinte.

\subsubsection{SEGUE: DA PRECLUSÃo DIRIGIDA À ATIVIDADE DO JUIZ}

Já se acenou no tópico anterior para a existência de corrente doutrinária que nega a ocorrência de preclusão dirigida à atividade do juiz, com base na ideia de CHIOVENDA ${ }^{198}$ de que se trataria de fenômeno que recai sobre faculdade processual, associada à noção de que ao juiz não assistem faculdades no processo.

Desde logo, necessário observar que, a análise das posições jurídicas assumidas pelos sujeitos processuais demonstra que somente em raríssimas situações se poderia falar em faculdade pura ${ }^{199}$. Na maioria das vezes, está-se diante de faculdade que possui como contrapartida um ônus ${ }^{200}$.

\footnotetext{
${ }^{197}$ Explica C. R. DinAMARCO: "Nesses casos, o prosseguimento do processo antes do decurso do prazo não acarreta preclusão alguma, porque isso transgrediria o direito de defesa e o devido processo legal. Por outro lado, embora a lei estabeleça prazo para a manifestação das partes, os juízos e tribunais atenuam esse rigor temporal e admitem que o autor fale mesmo depois de decorrido, só havendo preclusão se o processo tiver prosseguido. Por isso é que em casos assim, havidos por relativamente extraordinários no sistema, a preclusão depende do duplo requisito do decurso do prazo e eventual prosseguimento do processo (daí, ser ela mista). Instituições cit., v. 2, nota 8, p. 452.

${ }^{198}$ Explica o próprio G. CHIOVENDA que entende "por preclusão a perda, ou extinção, ou consumação de uma faculdade processual". Instituições cit., v. 3, p. 184.

199 “As faculdades processuais puras são muito poucas e revelam-se em atos de menor importância para a definição do processo.” C. R. DinAMARCO, Instituições cit., v. 2, p. 203.

200 “Ônus é, por definição, um imperativo do próprio interesse (James Goldschmidt). É encargo, ou peso. Ele é o reverso de certas faculdades outorgadas às partes e caracteriza-se pelas consequências desfavoráveis que a lei associa a algumas delas. Há ônus quando o cumprimento de uma faculdade é necessário ou ao menos conveniente para a obtenção de uma vantagem ou para evitar uma situação desvantajosa. Os ônus não são impostos para o bem de outro sujeito, senão do próprio sujeito a quem se dirigem. O descumprimento de um deles não causa malefício algum, ou diminuição patrimonial, nem frustra expectativas de outra pessoa. A parte tem plena liberdade de optar pela conduta ou pela omissão (daí, ser o cumprimento ou descumprimento do ônus uma faculdade), sabendo no entanto que, omitindo-se, agravará sua situação no processo (daí, tratarse de um ônus). C. R. DinAmarco, Instituições cit., v. 2, p. 204.
} 
De todo modo, essa circunstância não impede a parcela da doutrina que defende a inexistência de preclusão para o juiz ${ }^{201}$ de sustentar seu posicionamento com base na ausência de faculdades para o julgador no processo: se o juiz não tem faculdades, não tem como perdê-las. Esse é o pensamento, por exemplo, de CÂNDIDO DINAMARCO ${ }^{202}$, para quem, quando se fala que determinada decisão está preclusa, na verdade se está tratando da impossibilidade de a própria parte tornar a discutir a decisão - ou seja, da “inatacabilidade” da decisão -, e não da impossibilidade de o juiz tornar a decidir a questão que já tenha sido objeto daquele pronunciamento ${ }^{203}$. No mesmo sentido, embora tratando especificamente da cognição sumária que precede provimento cautelar, também já se manifestou BEDAQUE ${ }^{204}$.

Já JOÃo BATISTA LOPES, num primeiro momento, afirma que falar em preclusão para o juiz seria uma atecnia ${ }^{205}$, e, não obstante entender se trataria de preclusão sui generis, acaba por reconhecer que, em certas situações, a atividade do juiz está sujeita limitação de caráter preclusivo ${ }^{206}$.

Em contraposição, como já se acenou anteriormente, há vozes que defendem a existência de preclusão para o juiz, consistente na impossibilidade de redecidir

201 Conforme afirma expressamente C. R. DINAMARCO: "A ordem jurídico-processual não outorga faculdades nem ônus ao juiz." E prossegue: “o juiz não está no processo para gestão de seus próprios interesses, senão para regular os de outrem, ou seja, das partes. Não tem disponibilidade alguma sobre esses interesses, que não são seus, nem sobre as situações jurídico-processuais ocupadas por elas. Todos os poderes que a lei lhe outorga são acompanhados do dever de exercê-los.” Instituições cit., v. 2, p. 208.

${ }^{202}$ V. Instituições cit., v. 2, pp. 550, 626, Instituições cit., v. 3, pp. 142-145. É também o que se lê em estudo intitulado A reclamação no processo civil brasileiro: "Preclusão é, como se sabe, a perda de uma situação jurídica ativa no processo. Ordinariamente, nega-se que ao juiz se imponham preclusões, porque ele exerce o poder estatal e não faculdades, no próprio interesse" in Nova Era do Processo Civil, $1^{\mathrm{a}}$ edição, São Paulo, Malheiros, 2003, p. 201.

203 “A lei e mesmo a doutrina falam em decisões preclusas, mas na realidade o que preclui é a faculdade de impugnar as decisões, não elas próprias. Entenda-se, portanto: decisão preclusa é aquela que já não comporta impugnação alguma. Além disso, não só em relação a decisões se opera a decisão (sic). Ao réu revel está preclusa a faculdade de oferecer resposta à demanda inicial.” Instituições cit., v. 2, p. 452.

204 “Quanto à mera retratação, embora haja divergência na doutrina, não parece ocorrer o fenômeno da preclusão para o juiz. Primeiro porque a cognição realizada para a concessão de liminar em processo cautelar é sumaríssima, nada impedindo se convença o julgador da impropriedade da solução. Nesse caso, inexiste vedação legal a que ele altere sua posição, mesmo porque a providência determinada não visa a produzir efeitos definitivos no plano material." Tutela cautelar cit., p. 156.

205 “Tecnicamente, a preclusão é fenômeno processual que diz respeito tão-somente às partes. Considerada, em geral, como a perda da faculdade de praticar atos processuais, é natural que seu campo de atuação não alcance o âmbito próprio da atividade jurisdicional." Breves considerações cit..

206 "Entretanto, não se pode dizer que todos os atos do juiz estejam imunes à preclusão. Os doutrinadores costumam aludir à preclusão pro judicato, para designar uma espécie particular e imprópria de preclusão, que consistiria no impedimento ou barreira antepostos ao juiz, a fim de que ele não decida u'a mesma, questão mais de uma vez." Breves considerações cit.. 
questão que por ele próprio já tenha sido apreciada. Assim, entre outros, HuMBERTO TheOdOro JÚNIOR ${ }^{207}$, HeItOr SiCA ${ }^{208}$, TERESA WAMBIER ${ }^{209}$, e, de certa maneira, o próprio CHIOVENDA $^{210}$.

Seja como for, a doutrina de um modo geral reconhece que, em algum momento, o sistema impõe limitações também à atividade do juiz, por exemplo, pela impossibilidade de tornar a decidir questão sobre a qual tenha se pronunciado tribunal hierarquicamente superior, fenômeno denominado preclusão hierárquica ${ }^{211}$.

Nesse cenário, interessante a afirmação de FERNANDO CAIS no sentido de que a corrente doutrinária que nega a existência do fenômeno da preclusão dirigida às atividades do juiz se fundaria em "verdadeiro preconceito",212, que, no mais das vezes, diz

207 "Para o Juiz a preclusão existente é não a de faculdade e, sim, a de questão, conforme se deduz do art. 471 do CPC, onde se declara, categoricamente, que 'nenhum Juiz decidirá novamente as questões já decididas', salvo apenas as hipóteses excepcionais destacadas pelo próprio ordenamento jurídico. A preclusão pro iudicato é, portanto, a que decorre da questão já decidida e que ao Juiz não é dado reapreciar (preclusão consumativa)." A preclusão cit..

208 “[A] preclusão assume o caráter de fenômeno processual que impõe limitações ao exercício de poderes dentro do processo, nesse caso, os poderes decisórios do juiz”. Preclusão cit., p. 181.

209 “A preclusão, em nosso entender, pode dizer respeito quer às partes, quer ao juiz.” E prossegue: "não há como negar a necessidade de que se estabeleçam regras que, de um lado, não devem significar um embaraço para a atividade do juiz e que, de outro, não podem permitir que o processo se transforme em algo interminável. O equilíbrio entre estes dois desideratos é o que se busca, na fixação de regras relativas á possibilidade de que o juiz redecida o que já tenha sido, antes, resolvido." Os agravos cit., pp. 478 e 479 , respectivamente.

${ }^{210}$ Diz-se "de certa maneira", pois o processualista italiano não chegou a aprofundar seus estudos a respeito da preclusão de questões, embora tenha afirmado que "Pode haver preclusão limitada a um grau de processo, caso em que preclusão se contrapõe não só à coisa julgada como à preclusão definitiva que possa advir no curso do processo. É o que acontece com as questões decididas pelo juiz de primeira instância, por meio de sentença recorrível ou por juiz de segunda instância, por meio de sentença passível de recurso de cassação; as questões são preclusas com relação ao juiz que as decidiu, mas não com referência ao juiz superior. E isto em virtude do princípio bis de eadem re ne sit actio, interpretado no sentido que hoje se lhe atribui, a saber, de proibição de reproduzir uma demanda ou uma questão ao mesmo juiz que sobre elas já se houver pronunciado, e, com o pronunciamento, concluiu o que lhe incumbia.” Instituições cit., v. 3, p. 192.

211 "Decidida a matéria em grau superior, aos órgãos jurisdicionais menos elevados não cumpre senão dar cumprimento ao decidido, seja mediante a implantação das situações práticas determinadas, seja proferindo decisões sobre matéria subsequente ou prejudicada, de modo harmonioso com a decisão vinda do alto da hierarquia judiciária. O próprio pedido ou requerimento sobre o qual o tribunal houver decidido não comporta mais decisão alguma pelo órgão inferior. Isso é autêntica preclusão.” C. R. DinAMARCO, $A$ reclamação cit., p. 201.

212 “A corrente doutrinária que não admite a existência de preclusão para o juiz, em nosso entender, firma-se num verdadeiro preconceito, eis que seus defensores admitem a limitação de poderes decisórios do juiz, não aceitando, todavia, que esse fenômeno possa ser denominado simplesmente de preclusão. Em outras palavras, os seguidores dessa corrente estão de acordo que determinadas questões, uma vez analisadas pelo magistrado, não podem mais ser objeto de nova apreciação pelo mesmo órgão jurisdicional. Contudo, não concordam em denominar essa perda de poder do órgão jurisdicional de preclusão." Preclusão $e$ a instrumentalidade cit., pp. 21-22. 
respeito apenas à nomenclatura a ser dada ao fenômeno da limitação - que todos admitem ocorrer - à possibilidade do juiz de rever suas decisões.

Nesse ponto, convém também destacar que, como se falou, por vezes se utiliza a expressão "preclusão pro judicato" para fazer referência à impossibilidade de o juiz tornar a decidir questão que tenha apreciado anteriormente. No entanto, conforme explicam DANIEL AMORIM AsSUMPÇão NEVES ${ }^{213}$ e HeITOR SiCA ${ }^{214}$, a utilização dessa expressão não se mostra a mais adequada, posto que havia sido inicialmente cunhada por ENRICO REDENTI para tratar do efeito extraprocessual da decisão que determinava o pagamento em execução de título extrajudicial (ou monitória) que não tivesse sido objeto de impugnação e o crédito fosse satisfeito.

Nessa hipótese, a decisão que determinou o pagamento fundado no título projetaria efeitos para fora do processo. Contudo, segundo o próprio REDENTI, não se poderia falar em coisa julgada material por não ter havido decisão sobre o mérito. A esse efeito da decisão o jurista italiano chamou "preclusão pro judicato" 215 . Em atenção a essas observações, preferir-se-á não utilizar a terminologia preclusão pro judicato para tratar da preclusão que se dirige à atividade do juiz.

\footnotetext{
213 "Por imaginarem não se poder falar, dentro da concepção clássica, em preclusão dos poderes do juiz, alguns doutrinadores passaram a chamar tal situação com nomenclatura existente e com significado totalmente diferente. Na tentativa de se caracterizar uma espécie sui generis de preclusão, concernente à atividade judicial, alguns doutrinadores, tendo como pioneiro RICCIO, ainda na Itália, creditaram a esse fenômeno o nome de preclusão pro judicato". Preclusão pro judicato e preclusão judicial no processo civil brasileiro, dissertação (mestrado em Direito Processual), Faculdade de Direito - Universidade de São Paulo, São Paulo, 2002, capítulo 2, item 2.1.

214 “[A] expressão desenvolvida por REDENTI acabou sendo desvirtuada, como bem apontaram MONIZ DE ARAGÃo e, mais recentemente, ALEXANDRE BARROSO, porquanto aplicada a terrenos não imaginados por este último autor italiano e, o que é pior, designando situações em que a imutabilidade das questões resolvidas não opera extraprocessualmente", grifos do original. Preclusão cit., p. 93.

215 "Sappiamo, por esempio, che si può procedere ad esecuzione forzata processuale anche in virtù di titolo esecutivi stragiudiziali, senza che si accerti giudizialmente se il credito in realtà sussiste. Soltanto se i soggetti passivi insorgano, opponendosi alla esecuzione prima che si compiuta, potrà sorgerne un giudizio di cognizione e sboccare in un accertamento. Ma se opposizione non vi sia e l'esecuzione giunga indisturbata fino al suo termine, questo rappresenterà egualmente qualche cosa di irrevocabile e di irreparabile. Da questo momento nessuno potrà più insorgere contro il fatto compiuto per distruggerlo o infirmarlo. E in questi limiti si avrà un risultato pratico, simile a quello che si avrebbe, se fosse coperto dal giudicato. Si può parlare pertanto in questi casi di preclusioni pro judicato. Ed il fatto compiuto avrà le consuete conseguenze riflesse anche per i terzi." Diritto Processuale Civile, v. 3, Milano, Giuffrè, 1957, p. 71.
} 


\subsection{CONTORNOS DA PRECLUSÃo DIRIGIDA À ATIVIDADE DO JUIZ NO DIREITO BRASILEIRO}

Admitida a premissa de que o direito brasileiro prevê hipóteses em que o juiz não pode tornar a decidir questões a respeito das quais já tenha se manifestado, e que a esse fenômeno se pode chamar preclusão judicial, ou de questões ${ }^{216}$, cabe agora analisar, em linhas gerais, os contornos desse instituto.

Inicialmente, para que se possa ter noção do campo de incidência do fenômeno, convém compreender o que se entende por questão e de que maneira se podem identificar duas questões - de modo a se poder afirmar que são a mesma. Para os fins deste trabalho, parte-se da lição de CARNELUTTI ${ }^{217}$ segundo a qual questão é ponto controvertido, de fato ou de direito.

Contudo, tendo em vista a possibilidade de haver pontos a respeito dos quais o juiz deve se manifestar independentemente de ter havido provocação das partes (por exemplo, matéria processual, como as condições da ação), entende-se que a controvérsia é dispensável para a definição do conceito, mas não se pode dizer o mesmo a respeito da dúvida ${ }^{218-219}$. Assim, resumidamente e de maneira geral, por questões, entendem-se os pontos de fato ou de direito sobre os quais exista dúvida e que demandam manifestação motivada do juiz.

Para se falar em impossibilidade (ainda que em tese) de o juiz tornar a decidir - ou seja, em identidade de questões -, a questão já decidida e aquela a ser novamente apreciada devem versar sobre o mesmo ponto de fato ou de direito. Outrossim,

\footnotetext{
${ }^{216}$ H. V. M. SICA define o fenômeno como a limitação "sobre o próprio juiz prolator da decisão a respeito, impedindo-o de rever suas próprias decisões, fora dos casos de retratação previstos na lei e sujeitos à provocação do interessado" (grifo do original). Preclusão cit., p. 182.

217 “A questão não é a lide; de fato, esta consiste, antes de tudo, em um conflito de interesses que é estranho à questão; a questão, por sua vez, consiste em uma dúvida que pode ser estranha à lide. (...) Quando a lide apresenta uma ou mais questões, costuma-se falar de controvérsia (supra, $\mathrm{n}^{\circ}$ 5), que é, então, a palavra que se deve usar mais propriamente para denotar tal espécie de lide.” Instituições do Processo Civil, v. 1, $1^{a}$ edição, trad. Adrián Sotero De Witt Batista, São Paulo, Classic Book, 2000, p. 86.

218 "Não é indiferente o emprego dos vocábulos ponto e questão. Pontos são fundamentos, ou elementos capazes de influir em algum julgamento. Questão é o próprio ponto quando sobre ele existe alguma dúvida". C. R. DINAMARCO, Instituições cit., v. 3, p. 36.

219 “Quando a razão, da pretensão ou da contestação, seja duvidosa, surge uma questão, a qual, portanto, é a dúvida sobre uma razão.” F. CARNELUTTI, Instituições cit., v. 1, p. 88.
} 
os suportes fático e probatório que embasarão a nova decisão devem ser os mesmos que foram apreciados pelo juiz na primeira oportunidade de apreciação ${ }^{220}$.

É nesse cenário que se afirma que, se não tiver havido qualquer alteração fática ou probatória -, ainda que haja provocação da parte, o juiz não pode tornar a decidir questão a respeito da qual já tenha se pronunciado.

Sem prejuízo, tem-se que a preclusão consistente na impossibilidade de o juiz tornar a decidir questão que já tenha sido objeto de apreciação por ele próprio tem como consequência a aptidão do pronunciamento judicial se estabilizar dentro do processo, se não houver a interposição de recurso. Essa limitação está associada, de um lado, à preocupação com a razoável duração do processo e, de outro, à necessidade de conferir segurança jurídica às partes $^{221}$.

Nesse ponto, convém salientar que a insurgência da parte contra a decisão atua em dois planos: impedindo a ocorrência do fenômeno da preclusão para a própria parte - que está exercendo a faculdade de questionar novamente, nas hipóteses em que o sistema lhe permite, a solução dada pelo julgador a determinada questão ${ }^{222}$ - e possibilitando ao juiz emitir juízo de retratação. Em contrapartida, a inércia da parte, no sistema atual, implica que a decisão - se não versar sobre matéria que pode ser revista pelo próprio julgador - se estabilizará no âmbito endoprocessual.

Há quem defenda estar o fenômeno previsto no atual art. 471 do Código de Processo Civil ${ }^{223}$, que prevê que o juiz não decidirá novamente questões que já tenham sido decididas, sustentando ser essa orientação aplicável não somente às sentenças, mas

\footnotetext{
${ }^{220}$ Cf. H. V. M. SiCA, Preclusão cit., p. 199.

${ }^{221}$ Cf. H. V. M. SiCA, Preclusão cit., p. 183.

${ }^{222}$ Para C. R. DinAMARCO, essa seria, na realidade, o sentido que se poderia conferir à expressão "decisão preclusa": "A lei e mesmo a doutrina falam em decisões preclusas, mas na realidade o que preclui é a faculdade de impugnar as decisões, não elas próprias. Entenda-se, portanto: decisão preclusa é aquela que já não comporta impugnação alguma. Além disso, não só em relação a decisões se opera a decisão. Ao réu revel está preclusa a faculdade de oferecer resposta à demanda inicial.” Instituições cit., v. 2, p. 452.

${ }^{223}$ Art. 471: "Nenhum juiz decidirá novamente as questões já decididas, relativas à mesma lide, salvo:

I - se, tratando-se de relação jurídica continuativa, sobreveio modificação no estado de fato ou de direito; caso em que poderá a parte pedir a revisão do que foi estatuído na sentença;

II - nos demais casos prescritos em lei."
} 
também às decisões interlocutórias ${ }^{224}$. Essa é, por exemplo, a opinião de HUMBERTO THEODORO JÚNIOR ${ }^{225}$ e DANIEL AMORIM ASSUMPÇÃo NEVEs ${ }^{226}$.

Nesse cenário, a decisão interlocutória em primeiro grau de jurisdição que não verse sobre matéria cognoscível de ofício não pode ser reconsiderada a menos que tenha havido a interposição de agravo, que possibilita o exercício do juízo de retratação. Inclusive, essa é uma das principais funções de se comunicar ao juízo a quo a interposição do recurso, apresentando-lhe cópia das razões.

Em sentido contrário, GALENO LACERDA ${ }^{227}$, tratando do art. 289 do Código de Processo Civil anterior (1939), cuja redação foi reproduzida pelo art. 471 do atual CPC, afirma que tal comando somente se aplicaria à sentença, apoiando-se, de um lado, no conceito de lide - que se refere ao conflito de interesses no plano do direito material -, e, de outro, na própria exposição de motivos do anteprojeto daquela codificação ${ }^{228}$, em que se afirmou que no dispositivo mencionado se conteria a regra da imutabilidade da sentença,

${ }^{224}$ E. T. LIEBMAN, tratando da redação do art. 289 do CPC/1939, que possuía idêntica redação à do atual art.
471 , defendia a preclusão de questóes se estendia "indubitavelmente aos despachos interlocutórios, inclusive
o despacho saneador, os quais - posto que não tenham efeito de coisa julgada (art. 288 do CPC) - produzem,
se não recorridas (sic) ou não recorríveis, a preclusão das questões decididas, que tem efeito para todo o
processo no qual foram proferidos". E prossegue, tratando de "despacho interlocutório": "se forma sobre as
questões nele decididas, qualquer que seja a sua natureza, uma preclusão que impede ressuscitar a discussão
sobre elas no curso do mesmo processo, ressalvada unicamente a possibilidade dum recurso, quando for
permitido". Nota $n^{\circ} 225$ in G. CHIOVENDA, Instituições cit., v. 1, pp. 522-523. 225 "Para o Juiz a preclusão existente é não a de faculdade e, sim, a de questão, conforme se deduz do art. 471 do CPC (LGL 1973\5), onde se declara, categoricamente, que 'nenhum Juiz decidirá novamente as questões já decididas', salvo apenas as hipóteses excepcionais destacadas pelo próprio ordenamento jurídico. A preclusão pro iudicato é, portanto, a que decorre da questão já decidida e que ao Juiz não é dado reapreciar (preclusão consumativa)." A preclusão cit..

226 "No direito pátrio, a preclusão judicial vem expressa no artigo 471 do Código de Processo Civil (...). nem se fale, como pretendem alguns doutrinadores, que tal dispositivo deva somente ser aplicado à sentença, já que o juiz decide inúmeras questões em momento anterior à sua prolação, sendo o dispositivo legal em comento também aplicável a essas decisões." Preclusão pro judicato cit., capítulo 2, item 2.1.

227 "Indiscutivelmente, o que se veda no art. 289 é o duplo julgamento da questão relativa ao mérito do pedido, ressalvadas as exceções que menciona." Despacho saneador, $3^{\mathrm{a}}$ edição, Porto Alegre, Porto Alegre, Sergio Antonio Fabris, 1990, p. 166.

228 “A interpretação pretendida naufraga à simples consideração literal do texto: 'Nenhum juiz poderá decidir novamente as questões já decididas, relativas à mesma lide'. Ora, 'lide' tem um significado processual inequívoco, que o legislador brasileiro de 1939 não poderia ignorar. É o conflito material de interesses, qualificado pelos pedidos contraditórios das partes, ou seja, o mérito da causa, segundo a própria definição de LIEBMAN. E a confirmação de que o Código usou, com conhecimento de causa, o vocábulo 'lide', temo-la na interpretação de BATISTA MARTINS, autor do anteprojeto. Ao comentar o art. 289, em nenhum momento se refere à proibição de reexame das decisões interlocutórias, limitando-se a afirmar que nesse artigo 'se contém a regra da imutabilidade da sentença'. Muito ao contrário, a possibilidade de retratação das interlocutórias é por ele defendida, até com exagero, quando trata do despacho saneador." G. LACERDA, Despacho cit., p. 165. 
apenas. Na mesma esteira, e basicamente pelos mesmos argumentos já mencionados, CRUZ $\mathrm{E} \mathrm{TUCCI}^{229}$ sustenta também a inaplicabilidade do art. 471 às decisões interlocutórias.

Seja como for, para traçar os contornos do instituto, é impossível negar que em relação a pelo menos dois tipos de situações a atividade do juiz não está sujeita a preclusão: questões cognoscíveis de ofício e hipóteses em que haja previsão legal específica a afastar a preclusividade. E a dificuldade em sustentar seja a preclusão de questões a "regra" no nosso sistema reside em que essas hipóteses abrangem a maior parte das decisões interlocutórias ${ }^{230}$, e então a incidência do fenômeno somente se pode definir residualmente.

A possibilidade de o juiz conhecer de ofício algumas matérias excepciona a regra geral segundo a qual a cognição do juiz está atrelada aos pontos que tenham sido suscitados pelas partes e que tenham sido objeto de controvérsia. Por vezes, alude-se também à expressão "questões de ordem pública"231 para tratar de questões sujeitas à cognição de ofício pelo juiz.

Trata-se, portanto, de critério que se baseia no conteúdo da decisão, em relação ao qual se entende que, sob o fundamento da preponderância do interesse público sobre o privado ${ }^{232}$, nessas situações, com o poder de decidir independentemente de

229 "O que realmente vinha então vetado no ordenamento processual anterior, como mais claramente se denota no texto do dispositivo que lhe serviu de modelo, era o novo julgamento de questão sobre o próprio meritum causae, significando que o mesmo thema decidendum não poderia ser novamente suscitado como fundamento em tal questão, quer o juiz a tivesse decidido, quer não. Daí por que, bem analisado o problema, não poderia haver dúvida de que a norma em exame se referia tão-somente aos provimentos jurisdicionais definitivos." Sobre a eficácia preclusiva da decisão declaratória de saneamento, obtido em www.rtonline.com.br, originalmente publicado em Revista dos Tribunais, 640:1989, pp. 19 e seguintes (pp. 1-2 (arquivo eletrônico).

${ }^{230}$ De acordo com o art. 162, os pronunciamentos judiciais consistirão em sentenças, decisões interlocutórias e despachos. Quanto às primeiras, ante a literalidade do art. 471, não há dúvida a respeito da impossibilidade de o juiz decidir novamente ou modificar o conteúdo do ato, salvo nas hipóteses previstas no art. 535 do CPC (omissão, contradição, ou obscuridade), ou ainda para corrigir erro material, pois ao prolatar sentença o juiz exaure a sua competência. Em relação aos despachos, por não possuírem conteúdo decisório, não há que se falar em preclusão judicial, até porque não são sequer impugnáveis pela via de recurso.

${ }^{231}$ Fornecendo parâmetros a respeito do que poderia ser considerada questão de ordem pública, C. R. DiNAMARCO: "Incompetência absoluta, carência de ação, litispendência, coisa julgada, impedimento do juiz, dolo de uma das partes em detrimento da outra etc., são temas que sem a menor sombra de dúvida pertencem à ordem pública. Não é em exclusiva consideração às partes e a seus interesses, mas sobretudo por razões ligadas ao bom exercício da jurisdição, que a Constituição e a lei restringem ou condicionam o exercício da jurisdição em certos casos ou permitem a desconsideração da coisa julgada em outros." Instituições cit., p. 454. H. V. M. SICA critica a utilização do termo "questão de ordem pública", afirmando que se trata de expressão de conteúdo vago, e cujo emprego já foi feito até mesmo por regimes ditatoriais para defender interesses escusos. Preclusão cit., passim.

${ }^{232}$ Cf. H. V. M. SiCA, Preclusão cit., p. 249. 
alegação ou provocação a respeito, viria também o poder de redecidir ${ }^{233}$. Nesse rol, está incluída a matéria processual (pressupostos processuais e condições da ação ${ }^{234}$; $\operatorname{provas}^{235}$ ), e também outras situações de direito material, como a prescrição ${ }^{236}$.

Interessante a respeito a lição de GALENO LACERDA, que entende que o critério para se aferir se determinada decisão está sujeita à preclusão seria o seu conteúdo, e que a preclusividade está diretamente relacionada à disponibilidade das partes sobre a matéria que foi objeto da decisão ${ }^{237}$.

Dessa forma, nas hipóteses em que a decisão versa sobre matéria disponível, a não interposição de recurso implica aquiescência das partes com o pronunciamento judicial e, nesse sentido, impede que o próprio juiz reveja seu posicionamento anterior.

No entanto, o mesmo não ocorre quando se trata de matéria indisponível, em que decisão em desconformidade com a norma pode ser considerada, segundo classificação dele ${ }^{238}$, nula (pela violação a norma imperativa de interesse público ou de interesse da parte) ou anulável (pela infração a norma dispositiva do interesse da parte).

233 "Satisfaz-nos a ideia de que se a matéria é cognoscível de ofício - sendo de ordem pública ou não - a decisão judicial que a enfrenta está livre da preclusão. Vale repetir ainda uma vez: se o sistema reputou irrelevante a inércia da parte em arguir a questão, há de consectariamente reputar irrelevante a omissão do interessado em dela recorrer.” H. V. M. SiCA, Preclusão cit., p. 252.

${ }^{234}$ A esse respeito, ensina C. R. DinAMARCO: "Como o nome indica, pressupostos de admissibilidade do provimento jurisdicional são exigências postas pela lei como requisitos sem os quais o juiz não pode emitilo. A verificação da presença ou ausência de cada um deles é feita ao longo do arco do procedimento, a partir do momento em que o juiz aprecia a petição inicial (que será indeferida se faltar algum: arts. 295 e 616), depois nos momentos críticos indicados pela lei (arts. 329, 331) e, afinal, até mesmo quando o procedimento todo já foi cumprido e chega ao ponto de sentenciar. Não há preclusões para o juiz, quanto aos pressupostos do provimento (art. 267, $\S 3^{\circ}$ )". Instituições cit., v. 2, p. 616.

${ }^{235}$ J. R. CRUZ E TUCCI, em artigo no qual trata especificamente da decisão de saneamento do processo, afirma que a não interposição de recurso acarreta a preclusão para as partes; no entanto, o juiz “"[p]oderá, outrossim, rever o objeto da decisão saneadora, correspondente ao seu conteúdo ordenatório, que se refere à formação do livre convencimento, determinando a produção das provas entendidas necessárias à instrução do processo." Sobre a eficácia cit., p. 3 (arquivo eletrônico).

${ }^{236}$ Art. 219. A citação válida torna prevento o juízo, induz litispendência e faz litigiosa a coisa; e, ainda quando ordenada por juiz incompetente, constitui em mora o devedor e interrompe a prescrição. (...) $\S 5^{\circ} \mathrm{O}$ juiz pronunciará, de ofício, a prescrição.

237 “[A] preclusão no curso do processo depende, em última análise, da disponibilidade da parte em relação à matéria decidida. Se indisponível a questão, a ausência de recurso não impede o reexame pelo juiz. Se disponível, a falta de impugnação importa concordância tácita à decisão. Firma-se o efeito preclusivo não só para as partes, mas também para o juiz, no sentido de que vedada se torna a retratação.” Despacho cit., p. 160 .

${ }^{238}$ Cf. Despacho cit., p. 160. 
A nulidade ou anulabilidade da decisão implicam a desnecessidade de interposição de recurso para que o próprio juiz, apercebendo-se do erro, possa retratar-se, pois até mesmo acordo entre as partes não seria apto a convalidar a decisão que tenha ofendido a tais preceitos ${ }^{239}$.

Paralelamente, há situações em que o próprio sistema processual confere expressamente a possibilidade de o juiz tornar a decidir, independentemente do conteúdo do pronunciamento anterior, mediante provocação da parte com a interposição de agravo. Essa possibilidade, em especial, evidencia a relação entre a preclusão de questões e o atual regime de recorribilidade plena das decisões interlocutórias. Cabe, no entanto, ressaltar que a possibilidade de o próprio juiz rever a decisão agravada é distinta da possibilidade de essa mesma decisão vir a ser reformada por decisão do tribunal, e é o primeiro aspecto que aqui nos interessa.

Além dessas, há ainda as hipóteses em que o juiz pode, mediante provocação, reconsiderar (i) a sentença liminar de improcedência da ação, após a análise do recurso de apelação interposto pelo autor (art. 285-A, $\S 1^{\circ}$, do $\mathrm{CPC}^{240}$ ); (ii) o indeferimento da petição inicial, também na hipótese de interposição de recurso de apelação pelo autor (art. 296 do $\mathrm{CPC}^{241}$ ); e (iii) o recebimento de recurso de apelação diante de irregularidade apontada pelo apelado em contrarrazões (art. 518, $\S 2^{\circ}$, do $\mathrm{CPC}^{242}$ ).

As duas primeiras situações narradas no parágrafo anterior pouco interesse despertam para o tema deste trabalho, vez que tratam de sentenças, e não de decisões interlocutórias. No que diz respeito à última, embora se trate de decisão interlocutória, tendo em vista que versa sobre a admissibilidade de outro recurso - e contra ela própria cabe recurso de agravo - igualmente escapa ao objeto deste estudo.

\footnotetext{
${ }^{239}$ Essa opinião é secundada pela de C. R. DiNAMARCO, que assim se manifesta: "só a matéria sujeita à disponibilidade das partes é suscetível de preclusão e não a que diga respeito à ordem pública." Instituições cit., v. 2, p. 454.

${ }^{240}$ Art. 285-A. Quando a matéria controvertida for unicamente de direito e no juízo já houver sido proferida sentença de total improcedência em outros casos idênticos, poderá ser dispensada a citação e proferida sentença, reproduzindo-se o teor da anteriormente prolatada. $\S 1^{\circ}$ Se o autor apelar, é facultado ao juiz decidir, no prazo de 5 (cinco) dias, não manter a sentença e determinar o prosseguimento da ação.

${ }^{241}$ Art. 296. Indeferida a petição inicial, o autor poderá apelar, facultado ao juiz, no prazo de 48 (quarenta e oito) horas, reformar sua decisão.

${ }^{242}$ Art. 518. Interposta a apelação, o juiz, declarando os efeitos em que a recebe, mandará dar vista ao apelado para responder. (...) $\S 2^{\underline{o}}$ Apresentada a resposta, é facultado ao juiz, em cinco dias, o reexame dos pressupostos de admissibilidade do recurso.
} 
No que diz respeito à possibilidade de o juiz rever pronunciamento sobre antecipação de tutela, prevista no art. $273, \S^{\circ}$, do $\mathrm{CPC}^{243}$, a discussão se cinge menos à necessidade de provocação da parte e mais ao requisito da existência de elemento novo, considerado essencial por parte da doutrina, e dispensável por outra parcela.

Em síntese, argumenta-se que permitir que o juiz modifique a decisão concessiva de tutela antecipada sem que o substrato fático ou o conjunto probatório tenha se modificado traria insegurança às partes, principalmente àquela contra a qual a antecipação é deferida. Para esta parcela da doutrina, ao juiz não seria dado modificar seu entendimento diante das mesmas condições que o fizeram prolatar a mesma decisão anterior $^{244}$.

Contrapondo-se a essa posição, BEDAQUE afirma que o juiz não deve ser obrigado a manter decisão injusta, sendo necessário conferir-lhe a possibilidade de modificá-la caso se convença da impropriedade da decisão que anteriormente proferira ${ }^{245}$, ficando o necessário controle da sua atividade evidenciado pela fundamentação, em ambas as decisões.

\subsection{RELAÇÃo ENTRE PRECLUSÃo E RIGIDEZ DO PROCEDIMENTO}

Importante função associada ao fenômeno da preclusão é a de "coordenar" o andamento da marcha processual, impedindo o retrocesso a fases já superadas do

${ }^{243}$ Art. 273. O juiz poderá, a requerimento da parte, antecipar, total ou parcialmente, os efeitos da tutela pretendida no pedido inicial, desde que, existindo prova inequívoca, se convença da verossimilhança da alegação e: (...) $\S 4^{\circ}$ A tutela antecipada poderá ser revogada ou modificada a qualquer tempo, em decisão fundamentada.

${ }^{244}$ Cf., por exemplo, J. R. S. BEDAQUE, para quem "[s]e indeferido o pedido de tutela de urgência, deve a parte impugnar a decisão, sob pena de preclusão. Outra decisão a respeito somente será admissível diante de fatos novos. Idêntica a solução se a medida for cassada pelo tribunal. Não poderá o juiz de primeiro grau reexaminar a questão, salvo se sobrevier alguma modificação fática.” Tutela cautelar cit., p. 159.

E prossegue: "[t]ais afirmações não são incompatíveis com a natureza provisória da tutela de urgência. Sua concessão tem essa característica, o que significa possibilidade de modificação a qualquer tempo. Decisão denegatória, todavia, está sujeita às regras sobre preclusão. Tem a parte o ônus de recorrer da decisão, não podendo simplesmente renovar o pedido, com os mesmos fundamentos de fato." Tutela cautelar cit., p. 159.

E, no que diz respeito ao modo como o pedido foi apresentado, adverte, chegando à mesma conclusão: “[n]ão importa que a decisão seja proferida em procedimento autônomo ou não, nem o nome atribuído pelo requerente à tutela de urgência. Se indeferida a pretensão, necessária a interposição de recurso, sob pena de preclusão. Novo exame da matéria fora do âmbito recursal, somente se houver alteração fática." Tutela cautelar cit., p. 159.

${ }^{245}$ Cf. Tutela cautelar cit., p. 156. 
procedimento $^{246}$, vedando a que seja considerado ato que deveria ter sido praticado anteriormente, ou a que o juiz torne a decidir sobre questão que já tenha sido objeto de pronunciamento na mesma condição.

A divisão do procedimento em fases relativamente estanques que possuem finalidades específicas $^{247}$, em que há a estabilização da demanda ${ }^{248}$ após a resposta do réu, é consequência da opção brasileira por um sistema de procedimento rígido ${ }^{249}$, no qual vige o chamado princípio da concentração e se segue uma ordem sequencial destinada a preparar a prolação da sentença ${ }^{250}$.

Esse caráter de rigidez do procedimento pode ser percebido ainda que o Código não apresente disciplina orgânica da preclusão, apenas se referindo ao instituto em

${ }^{246}$ Cf. C. R. DINAMARCO, para quem: "da ordem estabelecida pelo Código de Processo Civil para a
realização dos atos processuais e da divisão do procedimento em fases resulta a inadmissibilidade de realizá-
los a qualquer tempo, o que seria um manifesto fator de desordem processual. À medida que o procedimento
caminha, vão-se fechando portas e, em princípio, os atos de parte que não se realizaram em tempo não mais
poderão ser realizados. O procedimento ordinário brasileiro é particularmente preclusivo - como de resto
todo o sistema procedimental deste país - e, na medida da relatividade de suas fases, de uma delas não se
retrocede a outra." Instituições cit., v. 3 , pp. $347-348$.

${ }^{247}$ Assim explica H. THEODORO JR.: "[o] procedimento ordinário é o mais completo e o mais apto à perfeita realização do processo de conhecimento, pela amplitude com que permite às partes e ao juiz pesquisar a verdade real e encontrar a justa composição da lide. Está estruturado segundo fases lógicas, que tornam efetivos os princípios fundamentais do procedimento, como o da iniciativa da parte, o do contraditório e o do livre convencimento do julgador. Para consecução de seu objetivo, o procedimento ordinário desdobra-se em quatro fases: a postulatória, a de saneamento, a instrutória e a decisória. Estas fases, na prática, nem sempre se mostram nitidamente separadas, e às vezes se interpenetram. O que, todavia, as caracteriza é a predominância de um tipo de atividade processual desenvolvida pelas partes e pelo juiz." Curso cit., p. 326.

C. R. DinAmarco fala em fases postulatória, ordinatória, instrutória e decisória, substancialmente com o mesmo conteúdo. Instituições cit., v, 3, pp. 346-347.

J. A. M. PINTO, em artigo dedicado ao tema da rigidez do procedimento em sua relação com a estabilização da demanda, com apoio em MARELLI, se refere a fases "preparatória, instrutória e decisória". Sistemas rígidos e flexiveis: a questão da estabilização da demanda in J. R. S. BEDAQUE e J. R. CRUZ E TUCCI (coords.), Causa de pedir e pedido no processo civil (questões polêmicas), São Paulo, Revista dos Tribunais, 2002, p. 57.

${ }^{248}$ J. A. M. PINTO assim se refere à estabilização da demanda: "concebida como o momento em que apresentadas todas as alegações pelas partes, estas não mais podem ser modificadas, preparando o processo para uma fase seguinte, da realização das provas, em que cada litigante se demonstrar a veracidade de suas alegações, seja o autor provando o fato constitutivo de seu direito, seja o réu provando o fato modificativo, impeditivo ou extintivo do direito do autor." Sistemas cit., p. 55.

${ }^{249}$ Em contraposição ao sistema de procedimento rígido, há o procedimento flexível, no qual "têm as partes, ou mesmo o juiz, o poder de adiar suas proposições, podendo em qualquer momento do processo, com a participação da parte contrária, apresentar fundamentos novos, aptos a sustentar o acolhimento de sua pretensão". J. A. M. PINTO, Sistemas cit., p. 57.

250 “O instituto da preclusão tem imensa relevância no sistema brasileiro de procedimento rígido. Ele dá apoio às regras que regem a ordem sequencial de realização dos atos do procedimento e sua distribuição em fases - fazendo-o mediante a imposição da perda de uma faculdade ou de um poder em certas situações. Quando a preclusão ocorre, já não poderá a parte realizar eficazmente o ato a que tinha direito nem exigir do juiz os atos que antes poderia exigir.” Instituições cit., v. 2, pp. 451-452. 
dispositivos esparsos (art. 245, caput e parágrafo único ${ }^{251}$; art. $473^{252}$ ), conforme salienta CÂNDIDO DINAMARCO ${ }^{253}$.

Dentro desta lógica, ao fim da chamada fase postulatória, destinada à exposição dos fatos e fundamentos jurídicos que fundamentam as pretensões das partes contrapostas, os elementos da demanda já não mais poderão ser alterados ${ }^{254}$. Isso contribui para que - respeitando os princípios do contraditório e da ampla defesa - possa o réu, já neste momento, saber quais provas terá que produzir e o risco ao qual está sujeito pela prolação de sentença desfavorável aos seus interesses ${ }^{255}$.

É evidente que algum nível de rigidez no procedimento contribui para a aceleração processual ${ }^{256}$, na medida em impede retrocessos. Ao mesmo tempo, favorece a ampla defesa - por permitir ao réu, de posse do conjunto das alegações do autor, deduzir todas as defesas e exceções que lhe sejam aproveitáveis -, e propicia a possibilidade de

251 “Art. 245. A nulidade dos atos deve ser alegada na primeira oportunidade em que couber à parte falar nos autos, sob pena de preclusão. Parágrafo único. Não se aplica esta disposição às nulidades que o juiz deva decretar de ofício, nem prevalece a preclusão, provando a parte legítimo impedimento."

252 “Art. 473. É defeso à parte discutir, no curso do processo, as questões já decididas, a cujo respeito se operou a preclusão."

${ }^{253}$ C. R. DiNAMARCo salienta que, “[m] esmo assim isolados, esses poucos dispositivos são suficientes para imprimir o caráter de rigidez ao modelo procedimental brasileiro. O último deles é o mais significativo, por ser dotado de abrangência geral. Associado às regras sobre a sucessão dos atos (supra, n. 26) e às fases que de algum modo o Código reconhece, ele é suficiente para impedir que se volte atrás." Instituições cit., p. 453, grifos do original.

254 “A fase postulatória é portanto aquela em que se define o objeto do processo mediante a demanda inicial e eventuais outras sucessivas, fixando-se desse modo os termos e limites em que se desenvolverá a causa. É também nessa fase que se instalam no processo os seus sujeitos, seja pela propositura da demanda inicial (autor), seja pela citação do réu ou de terceiro. É própria a ela, ainda, o estabelecimento das controvérsias entre as partes sobre os pontos de fato ou de direito, o que acontece na contestação oposta pelo réu à demanda inicial ou por terceiros citados em razão da denunciação da lide ou do chamamento ao processo.” C. R. DINAMARCO, Instituições cit., v 3, p. 349.

${ }^{255}$ Cf. J. A. M. PINTO, Sistemas cit., p. 56.

${ }^{256}$ Cf. C. R. DinAMARCO, Instituições cit., v. 2, p. 452. 
contraditório $^{257}$ efetivo, pois o réu não será surpreendido com novos argumentos e pedidos já ao fim do processo, depois de ampla produção probatória ${ }^{258}$.

Contudo, adverte a doutrina que a excessiva rigidez pode configurar fator de burocratização do procedimento ${ }^{259}$, razão pela qual se destaca o papel do juiz na condução do processo, de modo a evitar os desvios que poderiam desta circunstância poderiam $\operatorname{advir}^{260}$ - por exemplo, flexibilizando a regra geral da impossibilidade de alteração de causa de pedir após o final da fase postulatória se a questão tiver sido objeto de amplo contraditório, e desde que não resulte qualquer prejuízo para a defesa ${ }^{261}$.

Em complemento, salienta-se que vige em nosso sistema o princípio da eventualidade $^{262}$, segundo o qual as partes devem apresentar todas as suas alegações (ainda

${ }^{257}$ Em artigo dedicado ao tema, A. C. MARCATO assim se manifestou: "As preclusões operam internamente
no processo, estabilizando e consolidando as fases procedimentais que lhe dão vida, tendo sua razão de ser
única e exclusivamente a ele voltada. Já o contraditório dinamiza e torna possível o processo mesmo,
viabiliza a aplicação dos princípios da ampla defesa e da igualdade das partes; afastado que seja ele do
processo, torna-o nulo e nulo também o provimento afinal emanado do órgão jurisdicional. Em decorrência,
qualquer norma restritiva ou limitativa desse princípio nasce fadada à inaplicabilidade no processo, já que
inconstitucional", concluindo, assim, que as preclusões "não podem e não devem limitar o contraditório, quer
no processo penal, quer no civil". Preclusões: limitação cit., p. 7 (arquivo eletrônico).

${ }^{258}$ J. A. M. PINTO assim resume o quanto exposto: "a preclusão, sob este enfoque, apresenta-se como importante garantia aos litigantes, até mesmo porque podem com a adoção desta regra ter a certeza de que, após aquela fase previamente determinada para a produção de uma específica alegação, não serão surpreendidos com outras, pelas quais não se empenharam em se defender. Da mesma forma, a adoção por um determinado ordenamento da regra da eventualidade privilegiará, em última análise, o princípio do contraditório. A parte somente terá a efetiva possibilidade de se defender se tiver o pleno conhecimento de quais assuntos integrarão o objeto da decisão." Sistemas cit., p. 64.

${ }^{259}$ Assim G. LACERDA, ainda que sob outro enfoque: "[s]e o excesso de preclusões é condenável, porque o desumaniza, porque o transforma em máquina de expelir despachos, não é possível, entretanto, bani-las totalmente do direito processual". Despacho cit., p. 156.

${ }^{260}$ Nesse sentido, C. R. DinAMARCO: "a extremada rigidez seria fator de inevitável burocratização do processo, minimizando as faculdades das partes, apequenando o poder de direção processual inerente ao juiz e consequentemente, afastando o processo de seu primordial objetivo da (sic) fazer justiça (processo justo e équo)." Instituições cit., v. 2, p. 455, grifos do original.

${ }^{261}$ Assim J. R. S. BEDAQUE: "se, inadvertidamente, for introduzida no processo causa de pedir não deduzida na inicial e o contraditório abranger a nova realidade fática, não há por que desconsiderá-la. As regras da correlação, da eventualidade e da preclusão visam a assegurar a amplitude da defesa e o normal desenvolvimento do processo." Efetividade cit., p. 134. E adiante conclui o processualista, após ter ilustrado a ideia defendida com um exemplo concreto por ele vivenciado em sua experiência como desembargador: "[d]ecidiu-se assim por considerar, no caso, irrelevante a não-observância da forma, pois a providência determinada [no caso, permitir ao apelante emendar as razões de recurso, com a posterior manifestação do apelado] foi suficiente para restabelecer a segurança e manter íntegro o contraditório. Diante de eventual vício processual, deve o juiz tentar saná-lo. Somente se impossível essa alternativa, porque a falha comprometeu definitivamente a ampla defesa e o contraditório, a anulação orna-se a opção adequada. O que importa, em um primeiro momento, é o fim do processo - qual seja, a solução justa para o litígio." Efetividade cit., p. 135.

262 "Diferentemente de outras legislações, em especial a alemã e a italiana, nas quais sempre predominou a liberdade das partes na apresentação de suas respectivas alegações, é da tradição do processo brasileiro a adoção da regra da eventualidade, impondo aos demandantes o dever de propor, em um mesmo momento, 
que contraditórias entre si, notadamente no caso do réu) na mesma oportunidade, não lhes sendo franqueada a possibilidade de oferecer argumentos sucessivos após a rejeição dos principais, por exemplo.

O princípio da eventualidade, em última análise, consiste numa limitação à liberdade das partes de apresentarem seus fundamentos ${ }^{263}$ que se destina a evitar abusos no direito de demandar e de se defender ${ }^{264}$. Sua relação com a preclusão é bem explicitada por CELSO AGRÍCOLA BARBI, para quem a não apresentação das alegações com a inicial ou a contestação implica impossibilidade de o fazerem posteriormente justamente com fundamento na ocorrência deste fenômeno ${ }^{265}$.

Seja como for, a existência de um procedimento marcado por preclusões rígidas orienta o processo para a prolação da sentença, evitando contramarchas ${ }^{266} \mathrm{e}$ favorecendo a entrega da prestação jurisdicional.

No que diz respeito ao objeto deste estudo, pertinente a observação de HEITOR SicA, para quem a rigidez do procedimento, embora seja verificada a partir da

todos os meios de ataque e de defesa.” J. R. CRUZ E TUCCI, A causa petendi no direito processual civil brasileiro, v. 27, Coleção Estudos de Direito de Processo Enrico Tullio Liebman, $2^{\text {a }}$ edição revista, atualizada e ampliada, São Paulo, Revista dos Tribunais, 2001, p. 148.

${ }^{263}$ Para J. R. CRUZ E TUCCI, o sistema de preclusões do nosso ordenamento e a estabilização da demanda após a resposta do réu constituem pressuposto da teoria da substanciação que, segundo afirma $o$ processualista - com apoio em respeitável doutrina -, foi acolhida no país: "[t]udo isso significa que a regra da eventualidade, impondo um sistema rígido de preclusões, constitui, como já procuramos patentear, pressuposto da teoria da substanciação ao exigir a exposição simultânea, na petição inicial, dos fatos que fazem emergir a pretensão do demandante (causa petendi remota) e do enquadramento da situação concreta, narrada in status assertionis, à previsão abstrata, contida no ordenamento de direito positivo, e do qual decorre a juridicidade daquela (causa petendi proxima)." A causa petendi cit., p. 151, grifos do original.

Substancialmente de acordo, J. A. M. PINTO, Sistemas cit., p. 64.

${ }^{264}$ Segundo J. R. S. BEDAQUE, “[e]sta é, por exemplo, a razão pela qual os fatos constitutivos do pedido e a matéria de defesa devem ser apresentados, respectivamente, na inicial e na contestação, sendo vedadas porque preclusas - a modificação da demanda pelo autor após a citação e a dedução de novas alegações pelo réu (CPC, arts. 282, III, 300, 264 e 303)." Efetividade cit., p. 133.

${ }^{265}$ Em conhecido artigo sobre o tema, assim se manifestou o processualista: "o princípio da eventualidade tem como consequência impedir que quaisquer meios de ataque ou de defesa, não apresentados com a inicial ou com a contestação, o possam ser em momento posterior; com aquelas peças fica delimitada a controvérsia, os meios de que cada um pretende se utilizar para a vitória; nenhuma modificação é possível depois. O que acontece, portanto, é a preclusão da faculdade de apresentar novos meios de ataque ou defesa em outra fase. É, assim, a preclusão conceito indispensável ao princípio da eventualidade." Da preclusão no processo civil, obtido em www.rtonline.com.br, originalmente publicado em Revista Forense, 148:1961 - grifo do original.

${ }^{266}$ A esse respeito, adverte J. A. M. PINTO: "se não existisse, de alguma forma, a regra da eventualidade, sem a concentração dos atos procedimentais, e o processo pudesse marchar livremente, com a introdução de alegações tardias, e em qualquer momento, de acordo com a conveniência dos litigantes, o processo dificilmente atingiria seu escopo, tamanha a facilidade pela qual as partes poderia (sic) procrastinar e dilatar seu término." Sistemas cit., p. 64. 
liberdade concedida às partes quanto ao momento para deduzirem suas alegações, projeta efeitos também para o campo da atividade do juiz, comumente negligenciada em relação a esse assunto $^{267}$.

Isso porque, na linha do que já se expôs, a ocorrência da preclusão para as partes implica (em relação às questões não cognoscíveis de ofício) a impossibilidade de o juiz tornar a decidir. Existe, pois, uma relação de causa e efeito entre a ocorrência da preclusão para os sujeitos parciais e para o julgador, nessa situação.

Porém, segundo SICA, a possibilidade de o juiz, de ofício, rever posicionamento anterior - autorizada em inúmeras situações-, tem influência sobre o grau de rigidez do nosso sistema processual como um todo, na medida em que pode implicar o retorno a fase já superada do procedimento pela modificação de decisão que havia sido tomada em momento anterior ${ }^{268}$.

Conclui-se, assim, que o sistema brasileiro é de procedimento rígido, mas encontra válvulas de escape na atuação do juiz, seja para corrigir eventual desvio que eventualmente decorra da excessiva burocratização a que poderia conduzir a interpretação literal da lei, ou para rever decisão sobre matéria cuja relevância para o sistema é tamanha que pode ser conhecida de ofício ${ }^{269}$.

\subsection{RELAÇÃo ENTRE A PRECLUSÃo DE QUESTÕES E A IMPUGNAÇÃo DE DECISÕES INTERLOCUTÓRIAS}

Conforme já se expôs, o pronunciamento judicial que não verse sobre matéria cognoscível de ofício e que não tenha sido objeto de impugnação tempestiva -

\footnotetext{
267 “[O]utro erro de perspectiva dessa conceituação é deixar de lado a preclusividade que incide sobre os poderes do juiz de reapreciar o que já tiver sido decidido." Preclusão cit., p. 292.

268 “[E]sse aspecto influi sobremaneira na maior ou menor rigidez do procedimento, já que, seja de ofício, seja por meio de pedidos de reconsideração, a ordem dos atos encadeados no procedimento pode se flexibilizar, permitindo-se que retorne a fases anteriores para reanálise de questões que já haviam sido superadas." Preclusão cit., p. 292.

${ }^{269}$ H. V. M. SICA entende que as fases do processo civil brasileiro não são assim tão rígidas e estanques quanto se costuma afirmar, afirmando que "há fases no processo, certamente que sim, mas apenas quando se segue o modelo padrão previsto no Código, pois a aplicação de diversos dispositivos previstos desfigura esse sistema dito rígido e, consequentemente, altera o regime de preclusões sobre questões incidentais." Preclusão cit., p. 291.
} 
sobre o qual, via de consequência, tenha se operado a preclusão para as partes - tem aptidão para se estabilizar no âmbito endoprocessual; e isso por conta do impedimento a que o juiz torne a decidir a mesma questão sem que tenha havido provocação da parte associada a fato ou prova novos.

Entretanto, a interposição de agravo pela parte prejudicada habilita o prolator da decisão agravada a exercer juízo de retratação, reconsiderando a decisão agravada após a análise das razões do recurso. Deixando de lado considerações de ordem prática a respeito, por exemplo, da frequência com que os julgadores reconsideram suas próprias decisões, tem-se que, no plano teórico, essa possibilidade evidencia a relação entre a preclusão de questões e a recorribilidade das decisões interlocutórias.

Por um lado, não se pode negar a necessidade, no sistema, de um mecanismo de reanálise imediata das decisões interlocutórias - especialmente nas situações em que a apreciação pelo órgão recursal de determinada questão somente ao final do processo poderia trazer dano considerável à duração do processo ou prejuízo irreparável à parte. Atualmente, atende-se a essa demanda com o recurso de agravo de instrumento.

Contudo, essas hipóteses configuram, ao menos na teoria, exceção no sistema recursal, tanto que seu cabimento, na fase cognitiva, está condicionado à suscetibilidade de a decisão causar lesão de grave e difícil reparação ${ }^{270}$ e o recurso pode, por decisão irrecorrível, ser convertido pelo próprio relator em agravo retido ${ }^{271}$.

De outro lado, nas demais situações, em que se aplica a regra geral da impugnação às decisões interlocutórias - pela via do agravo retido - a parte manifesta seu inconformismo no prazo de dez dias após a intimação da decisão, ofertando razões de recurso ao próprio órgão prolator da decisão agravada; o recurso será apreciado pelo tribunal ad quem somente por ocasião do julgamento de eventual recurso de apelação.

Nesse contexto, tendo em vista que a apreciação do agravo retido está condicionada, primeiramente, à existência de um recurso de apelação e, em segundo lugar, à reiteração do interesse no conhecimento do agravo retido, parece razoável o

\footnotetext{
${ }^{270}$ Cf. art. 522, CPC.

271 “Atualmente, em razão das modificações oriundas da Lei 11.187/2005,a decisão do relator que determina a conversão do agravo de instrumento em agravo retido, assim como aquela relativa à concessão de efeito suspensivo ou antecipação da tutela recursal (art. 527, incs. II e III), são irrecorríveis.” T. A. A. WAMBIER, Os agravos cit., p. 254.
} 
entendimento de que uma das principais funções desta modalidade de recurso seria possibilitar o juízo de retratação, ainda que como consequência de a parte ter evitado a preclusão para ela própria ${ }^{272}$.

Convém ainda esclarecer que os pedidos de reconsideração de decisões interlocutórias - meios informais de impugnação ${ }^{273}$, frequentes na prática forense, mas não previstos pelo ordenamento ${ }^{274}$ - não têm o condão de alterar o quadro acima descrito, na medida em que não atuam para evitar a ocorrência da preclusão para as partes nem para o juiz.

Com efeito, o pedido de reconsideração não interrompe nem suspende o prazo para a interposição do recurso de agravo, não sendo, portanto, apto a impedir a ocorrência da preclusão para a parte. De maneira semelhante, sua utilização somente pode gerar a reforma da decisão nas situações em que a matéria decidida pudesse ser conhecida de ofício; em relação às demais, na linha do que já se expôs, o juiz está impedido de reapreciar a questão ${ }^{275}$.

Diante do exposto, é possível verificar que esse expediente impugnatório não possui qualquer influência na ocorrência da preclusão ${ }^{276}$, mesmo quando a parte

\begin{abstract}
${ }^{272}$ Assim se manifesta H. V. M. SICA a respeito: "a interposição dessa modalidade recursal [agravo retido] (que hoje constitui regra sobre o agravo de instrumento, consoante a Lei $\mathrm{n}^{0} 11.198 / 2005$ ) tem como finalidades únicas provocar o juízo de retração e evitar a preclusão (permitindo que a instância recursal possa conhecer da questão quando e se julgar apelação da sentença final). Não houvesse a preclusividade das questões incidentais - permitindo-se que a instância ad quem, em grau de apelação, conheça de qualquer questão incidental decidida pelo juiz singular, mesmo a despeito do agravo retido -, não teria razão de existir esse recurso. Igualmente, se pudesse o juiz singular e prolator de decisão interlocutória modificá-la quando bem quisesse, não haveria razão de ser o juízo de retratação do recurso de agravo (não só retido, como também de instrumento)." Preclusão cit., p. 228.
\end{abstract}

${ }^{273}$ Cf. T. A. A. WAMBIER, Os agravos cit., p. 479.

274 “Sem dúvida, tornou-se usual o pedido de reconsideração porque, sendo medida [não] disciplinada pela lei, e que não tem, pois, procedimento previsto, a parte dela se serve sem se preocupar com prazo, preparo, articulação de razões e formação de instrumento." Os agravos cit., p. 481.

275 “"[S]ob a égide do atual Código de Processo Civil (LGL 1973\5), com a clara estatuição dos recursos e o metódico estabelecimento dos pressupostos de cada qual, mormente do agravo de instrumento, possibilitando (CPC (LGL 1973\5), art. 527, in fine, e seu § 5.o), mediante contraditório e observância do due process of law, a eventual modificação do judicialmente deliberado, não se justifica o acolhimento de pedido de reconsideração assim avulso, sem forma nem figura de juízo.” A. V. R. VASCONCELOS, $O$ pedido de reconsideração e a preclusividade das decisões judiciais, obtido em www.rtonline.com.br, originalmente publicado em Revista dos Tribunais, 616:1987, pp. 17 e seguintes, p. 2 (arquivo eletrônico).

${ }^{276} \mathrm{Na}$ linha da conclusão a que chegou T. A. A. WAMBIER: "o fato de haver ou não pedido de reconsideração é tecnicamente irrelevante. Em verdade, pois, ao pedido de reconsideração só se pode seguir alteração da decisão nos casos em que o juiz poderia, até mesmo sem o pedido, alterar sua decisão. E a alteração da decisão há de ser fundamentada, como se de outra decisão se tratasse, porque, na realidade, é outra decisão." Os agravos cit., p. 483 (grifo do original). 
apresenta outras razões (naturalmente, cuida-se de razões que já poderiam ter sido apresentadas e não o foram, e não de novas razões) - e nem poderia ser diferente, sob pena de ofensa aos princípios da eventualidade e do contraditório ${ }^{277}$.

Essas considerações serão retomadas quando se tratar do impacto da supressão do agravo retido no sistema processual, conforme a proposta de novo $\mathrm{CPC}^{278}$. Por fim, cabem apenas duas pertinentes observações de GALENO LACERDA que, embora tenham sido feitas a respeito do despacho saneador, aqui se aplicam integralmente.

Em primeiro lugar, a existência de recurso contra as decisões interlocutórias não é prova de que a decisão do juízo a quo a respeito esteja sujeita à preclusão em todos os casos. $\mathrm{Na}$ linha do que já se expôs, há matérias sobre as quais não incide a preclusão de questões (pressupostos processuais, condições da ação, controle da regularidade formal do processo, produção de provas, etc.), e em relação às quais, a rigor, seria até mesmo desnecessária qualquer impugnação para que o juiz pudesse rever o posicionamento anterior $^{279}$.

Finalmente, associada ao que se expôs no parágrafo anterior e à ideia de que a preclusividade está relacionada à disponibilidade das partes sobre a matéria versada na questão decidida por interlocutória, está a noção de que nem sempre será necessária a interposição de recurso para a modificação de decisão interlocutória, mas somente nas hipóteses em que o assunto não possa ser conhecido de ofício pelo juiz ${ }^{280}$.

\footnotetext{
${ }^{277}$ Isso porque, conforme explica A. V. R. VASCONCELOS, "Pouco importa que ao juiz não estivessem presentes, no momento da deliberação da matéria incidente, todos os argumentos concernentes à questão controvertida: basta tenham tido os litigantes a oportunidade de oferecer suas teses e debater suas razões, obedientes ao princípio da eventualidade", obviamente ressalvadas as questões cognoscíveis de ofício. $O$ pedido cit. p. 2 (arquivo eletrônico).

${ }^{278}$ V. infra, item 7.3.1.

279 "Dir-se-á que a existência do recurso prova o caráter preclusivo do despacho. O argumento, em sua generalização, é sofístico. O recurso existe porque o despacho, conforme a natureza da questão, pode precluir ou fazer coisa julgada. Quando tais efeitos não se gerarem, a impugnação formal, a rigor, poderia inexistir." Despacho cit., p. 166 (grifo do original).

280 “O simples fato da possibilidade de recurso não autoriza afirmar, dogmaticamente, como LIEBMAN, que a modificação da interlocutória só se admitirá mediante impugnação legal, de tal forma que, na ausência desta, se opere a preclusão imediata do despacho, inclusive para o juiz.” Despacho cit., p. 163.
} 


\subsection{BREVE NOTÍCIA SOBRE A PRECLUSÃO DE QUESTÕeS NO DIREITO PROCESSUAL CIVIL ITALIANO}

No que diz respeito à preclusão dirigida à atividade das partes, o sistema processual civil italiano é tradicionalmente mais flexível que o brasileiro, pois evoluiu a partir de uma codificação inspirada no Código de Processo Civil francês, marcado por ideais liberais. Sob a égide dessa codificação, a liberdade das partes para a introdução de novos fatos e pedidos - e de modo geral para atuar na condução do processo, ditando seu ritmo e seu desenvolvimento - era ampla ${ }^{281}$.

Os desvios que decorriam dessa possibilidade levaram o legislador italiano a restringir a liberdade das partes para a dedução de novas alegações no Código promulgado em 1940 (que entrou em vigor em 1942), estabilizando o objeto da demanda na chamada prima udienza di trattazione. Este diploma foi notadamente influenciado pelas reformas do processo civil alemão e austríaco no final do século XIX, que trouxeram visão mais publicista da jurisdição, na qual o processo deixa de ser um assunto privado das partes ${ }^{282}$.

Tamanha restrição à liberdade das partes (ainda que, nessa época, as preclusões fossem "elásticas"), segundo a doutrina, não foi bem aceita pelos operadores locais do direito, tendo sido flexibilizada por reforma que ocorreu em $1950^{283}$.

\footnotetext{
${ }^{281}$ Cf. ensina A. Proto Pisani, tratando do processo no Código de Processo Civil de 1865: "il processo è concepito come un affare privato delle parti le quali hanno il monopolio non solo in ordine alla proposizione della domanda giudiziale (cioè in ordine alla facoltà di mettere in moto il processo), ma anche in ordine allo svolgimento del processo: le parti determinano i ritmi di svolgimento del processo, esse sole posso provocare l'acquisizione delle prove al giudizio, al loro esclusivo arbitro è rimessa la possibilità di potere modificare le domande già proposte, proporre nuove eccezioni, chiedere l'assunzione di nuovi mezzi di prova nel corso del processo". Appunti cit., p. 23.

282 "Il processo cessa di essere un affare privato delle parti; una volta proposta la domanda giudiziale la legge attribuisce al giudice ampi poteri per consentirgli sia di collaborare con le parti nella determinazione del thema decidendum e del thema probandum, sia di acquisire anche di ufficio mezzi di prova al processo." Appunti cit., p. 26. E prossegue, explicando que "con terminologia moderna si può dire che l'aumento dei poteri del giudice costituisce lo strumento tecnico attraverso cui queste riforme (ed in particolare quella austriaca) miravano ad eliminare quegli ostacoli di fatto che impedivano una eguaglianza sostanziale delle parti litiganti." Appunti cit., p. 26.

283 "Nata male (anche per la tragica scelta del momento in cui il nuovo codice di procedura civile entro in vigore), la riforma del processo ordinario di cognizione sarebbe poi stata del tutto stravolta dalla legge 14 luglio 1950 n. 581 (la c. D. Novella del '50) con la modifica del regime della introduzione della causa avanti il tribunale, l'eliminazione delle preclusioni ricollegate dal testo originario al momento della prima udienza di trattazione, l'introduzione dell'istituto del reclamo immediato al collegio avverso le ordinanze del giudice istruttore relative all'ammissibilità o rilevanza dei mezzi di prova, e la previsione della impugnabilità immediata delle sentenza non definitive su questioni preliminari di rito e di merito." A. PROTO PISANI, Appunti cit., pp. 31-32.
} 
Com a Novella de 1990, passou-se a prever preclusões mais rígidas ${ }^{284}$ para as partes, com a estabilização da demanda ao fim da fase postulatória, tal como ocorre atualmente no Brasi1 ${ }^{285}$. Porém, a regra do direito italiano, ainda assim, é mais flexível do que a do direito brasileiro, pois contempla algumas possibilidades de atenuação que não estão presentes - ao menos não positivadas - no nosso ordenamento.

Para analisar o fenômeno da preclusão dirigida à atividade do juiz no direito italiano, há que se ter em mente que aquele sistema contempla três tipos de pronunciamentos judiciais: sentenza, ordinanza e decreto ${ }^{286}$, e que a lei estabelece qual tipo deve ser emitido em cada situação e os requisitos de cada um, ressalvando que, na hipótese de não haver tal previsão, o ato judicial deve ter a forma que melhor se adequar ao escopo pretendido ${ }^{287}$.

O processo civil italiano obedece à ideia de que toda decisão que resolver questões ao longo do procedimento será considerada sentença, e toda sentença deverá ser impugnável ${ }^{288}$. Portanto, sentenza, que pode ser interlocutória ou final, é ato decisório cujos requisitos - dentre os quais a motivação - estão previstos em lei ${ }^{289}$, com vocação para a

\footnotetext{
284 “Observa-se que se procurou valorizar o procedimento de primeiro grau de jurisdição sobretudo com a introdução de fases preclusivas bem nítidas, a proibição de serem formulados novos pedidos em grau de apelação e a exequibilidade da sentença definitiva.” J. R. CRUZ E TUCCI, Diretrizes do novo processo civil italiano, obtido em www.rtonline.com.br, originalmente publicado em Revista de Processo, 69:1993, pp. 113 e seguintes, p. 1 (arquivo eletrônico).

285 “Curioso notar que muitas das novidades que agora foram adotadas pelo legislador italiano já haviam sido consagradas em nosso Código de Processo Civil (LGL 1973/5) de 1973, evidenciando, de um lado, o rigor científico do Diploma brasileiro, e, de outro, que o intolerável problema da morosidade do processo não decorre simplesmente de aspectos de natureza técnica, mas, sim, de vetores de ordem política, econômica e cultural.” J. R. CRUZ E TUCCI, Diretrizes cit., p. 2 (arquivo eletrônico).
}

${ }^{286}$ L. E. B. PACífICO, em capítulo dedicado ao processo civil italiano, utilizou-se das expressões "sentença", "ordenação" e "decreto" para tratar, respectivamente, de sentenza, ordinanza e decreto, tradução que será utilizada também ao longo deste trabalho. Direito Processual Civil Italiano in J. R. CRUZ E TUCCI (coord.), Direito Processual Civil Europeu Contemporâneo, 1ª edição, São Paulo, Lex, 2010, p. 266.

${ }^{287}$ Art. 131 (Forma dei provvedimenti in generale) do Codice di Procedura Civile italiano - "La legge prescrive in quali casi il giudice pronuncia sentenza, ordinanza o decreto. In mancanza di tali prescrizioni, $\mathrm{i}$ provvedimenti sono dati in qualsiasi forma idonea al raggiungimento del loro scopo."

${ }^{288}$ Cf. G. ChIOvENDA: "El principio del derecho germánico, según el cual, toda resolución de cuestiones durante el curso del proceso se consideraban como sentencia (interlocutoria), y toda sentencia, definitiva o interlocutoria, estaba sujeta a la impugnación, para prevalecido en el derecho medioeval italiano sobre el principio del derecho romano que sólo consideraba como sentencia la definicíon de la contienda y no admitía impugnaciones autónomas de las interlocutiones. El mismo principio germánico ha pasado al derecho actual italiano, que admite las impugnaciones contra toda sentencia, definitiva o interlocutoria, no exceptuada expresamente". Principios cit., tomo II, p. 478.

${ }^{289}$ Art. 132 (Contenuto della sentenza) do Codice di Procedura Civile italiano - "La sentenza è pronunciata in nome del popolo italiano e reca l'intestazione: Repubblica Italiana. Essa deve contenere: 1) l'indicazione del giudice che l'ha pronunciata; 2) l'indicazione delle parti e dei loro difensori; 3) le conclusioni del 
estabilidade $^{290}$, que pode ser de mérito ou de rito ${ }^{291}$, conforme decida o fundamento da demanda, ou verse sobre questão prejudicial ou obstáculo que impeça a apreciação do mérito.

Ordinanza ${ }^{292}$ é ato ordinatório por meio do qual o juiz, no exercício da sua função de condução do processo ${ }^{293}$, determina providências para assegurar o seu regular desenvolvimento. Porém, por meio de ordinanze, o juiz pode também decidir - ainda que de maneira provisória - certas questões propostas pelas partes ${ }^{294}$, conforme se verá adiante. Até por essa razão, a ordinanza deve ser precedida de contraditório e também motivada, ainda que sucintamente. Por força de expressa disposição legislativa, os pronunciamentos do juízo de instrução são emitidos sob a forma de ordenações ${ }^{295}$.

Por fim, decreto ${ }^{296}$ é também ato ordinatório pelo qual o juiz determina providências de caráter não jurisdicional, ou administrativo ${ }^{297}$. Por isso mesmo, prescinde

pubblico ministero e quelle delle parti; 4) la concisa esposizione delle ragioni di fatto e di diritto della decisione; 5) il dispositivo, la data della deliberazione e la sottoscrizione del giudice."

290 “Si identifica nella sentenza per forza di tradizione, l'atto decisorio tipico, in cui si realizza - con l'imperatività delle statuizioni e con la stabilità dei loro effetti, dopo la formazione del giudicato - la massima espressione della funzione giurisdizionale." L. P. Comoglio, C. Ferri, M. TARufFo, Lezioni sul processo civile, $1^{\text {a }}$ edição, Bologna, Il Mulino, 1995, p. 428.

291 "Nella prospettiva contenutistica, la sentenza: 1) è di merito, quando accoglie, in tutto o in parte, la domanda giudiziale, accertandone il fondamento, oppure, in tutto od in parte, la respinge dichiarandola non fondata; 2) è di rito, quando invece, risolvendo in senso positivo talune questione pregiudiziali o comunque verifica l'esistenza di ostacoli tecnici, che impediscono al giudice di pervenire ad una pronunzia di merito" $\mathrm{L}$. P. COMOglio, C. Ferri, M. TARUfFo, Lezioni cit., p. 428.

${ }^{292}$ Art. 134 (Forma, contenuto e comunicazione dell'ordinanza) do Codice di Procedura Civile italiano "L'ordinanza è succintamente motivata. Se è pronunciata in udienza, è inserita nel processo verbale; se è pronunciata fuori dell'udienza, è scritta in calce al processo verbale oppure in foglio separato, munito della data e della sottoscrizione del giudice o, quando questo è collegiale, del presidente."

${ }^{293}$ Cf. art. 174 (Direzione del procedimento) do Codice di Procedura Civile italiano.

294 “Nei molteplici casi previsti dalla legge, l'ordinanza si pone come provvedimento ordinatorio per eccellenza, con cui il giudice - nel più ampio contesto delle sue attribuzioni direttive - non si limita ad impartire disposizioni per un ordinato svolgimento delle attività processuali, ma spesso risolve, perlopiù in via provvisoria, vere e proprie questioni insorte fra le parti.

Essa, in rapporto al suo scopo funzionale, - presuppone costantemente la previa instaurazione del contraddittorio fra i soggetti in lite (come accade, ad esempio, nei casi previsti dagli artt. 625, commi 1 e 2, 672, comma 4, 673, comma 3, 689 e 690, nonché, dopo la Novella del 1990, dall'art. 669 novies, commi 1 e 2); - deve essere 'succintamente motivata' (per quanto sia, spesso, 'non impugnabile'), a garanzia dei diritti di difesa e del riesame cui essa e comunque esposta, nel corso del procedimento". L. P. COMOGLIO, C. FERRI, M. TARUFFO, Lezioni cit., p. 432.

${ }^{295}$ Art. 176 (Forma dei provvedimenti) do Codice di Procedura Civile italiano - "Tutti i provvedimenti del giudice istruttore salvo che la legge disponga altrimenti hanno la forma dell'ordinanza."

${ }^{296}$ Art. 135 (Forma e contenuto del decreto) do Codice di Procedura Civile italiano - "Il decreto è pronunciato d'ufficio o su istanza anche verbale della parte. Se è pronunciato su ricorso, è scritto in calce al medesimo. Quando l'istanza è proposta verbalmente, se ne redige processo verbale e il decreto è inserito 
de motivação e de prévio contraditório, diferentemente do que ocorre com a ordinanza. Trata-se de provimento que, pela sua estrutura e função, se assemelha ao despacho previsto no art. 162 do Código de Processo Civil brasileiro, não estando igualmente sujeito a recurso $^{298}$.

As sentenças se sujeitam ao recurso de apelação (appello) ${ }^{299}$, imediatamente, ainda que não sejam definitivas. Porém, a parte pode fazer a chamada reserva de recurso para evitar a preclusão, de modo a que a questão decidida possa ser levada ao conhecimento do órgão competente para julgar o recurso em outra oportunidade (quando de eventual recurso contra a sentença definitiva ou contra outra sentença interlocutória $)^{300}$

Via de regra, não há recurso cabível contra as ordenações, pois são pronunciamentos revogáveis pelo próprio órgão prolator - até mesmo de ofício e

nello stesso. Il decreto non è motivato, salvo che la motivazione sia prescritta espressamente dalla legge; è datato ed è sottoscritto dal giudice o, quando questo è collegiale, dal presidente."

297 "Dal canto suo, il decreto e un provvedimento ordinatorio - perlopiù di portata interna al processo, e di natura sostanzialmente non giurisdizionale (od amministrativa) - la cui adozione prescinde, di norma, dalla preventiva instaurazione del contraddittorio, non essendo istituzionalmente diretta a risolvere alcuna questione insorta fra le parti, tranne in casi tassativi.” L. P. COMOGLIO, C. FerRI, M. TARUFFO, Lezioni cit., p. 433.

298 “"[I]n linea di massima, non lo si reputa modificabile o revocabile dal giudice che lo abbia emesso, ma, nelle ipotesi previste dalla legge, esso si espone a forme variabili di modificabilità, di controllo e di riesame (talvolta, per mezzo di un reclamo a giudici diversi o per effetto allo stesso giudice...)". L. P. ComogLIO, C. FERRI, M. TARUFFO, Lezioni cit., p. 433.

299 "Con il mezzo dell'appello possono essere impugnate le sentenze pronunciate in primo grado". L. P. Comoglio, C. Ferri, M. TARUfFo, Lezioni cit., p. 683. E também: "Per quanto concerne il processo civile, l'art. 339 C.P.C. configura i casi di inappellabilità delle sentenze come eccezioni ad una regola (salvoché si tratti di sentenze pronunciate dal conciliatore, per le quali - art. 339 comma $3^{\circ}$ C.P.C. - il rapporto 'regolaeccezione' risulta rovesciato)." M. CHIAVARIO, Processo e garanzie della persona, v. 1 Profili istituzionali di diritto processuale, $2^{\mathrm{a}}$ edição, Milano, Dott. A. Giuffrè, 1982, p. 187.

${ }^{300}$ Art. 340 (Riserva facoltativa d'appello contro sentenze non definitive) do Código de Processo Civil italiano: "Contro le sentenze previste dall'articolo 278 e dal n. 4 del secondo comma dell'articolo 279 , l'appello può essere differito, qualora la parte soccombente ne faccia riserva, a pena di decadenza, entro il termine per appellare e, in ogni caso, non oltre la prima udienza dinanzi al giudice istruttore successiva alla comunicazione della sentenza stessa.

Quando sia stata fatta la riserva di cui al precedente comma, l'appello deve essere proposto unitamente a quello contro la sentenza che definisce il giudizio o con quello che venga proposto, dalla stessa o da altra parte, contro altra sentenza successiva che non definisca il giudizio.

La riserva non può più farsi, e se già fatta rimane priva di effetto, quando contro la stessa sentenza da alcuna delle parti sia proposto immediatamente appello." 
implicitamente $^{301}$ - e não prejudicam de nenhuma forma a sentença posterior ${ }^{302}$. Contudo, há duas ordens de exceções a essa regra, que se passa a expor brevemente.

De um lado, o Código estabelece que ordenações emitidas por juízo de instrução relativas a determinadas matérias não podem ser revogadas pelo órgão prolator. É o que ocorre em relação (i) à ordenação homologatória de acordo entre as partes, quando se tratar de matéria disponível; (ii) as ordenações expressamente declaradas não impugnáveis pela lei; e (iii) as ordenações para as quais a lei preveja um meio específico de impugnação ${ }^{303}$, como é o caso, por exemplo, da ordenação que decide sobre competência, que se sujeita ao regolamento di competenz $a^{304}$.

De outro lado, é possível a impugnação das ordinanze, por reclamo - nas situações previstas nos arts. 178 e 357 do CPC italiano - e por appello, contra o provimento antecipatório emitido sob a forma de ordenação na hipótese do art. 186quater $^{305}$.

\footnotetext{
${ }^{301}$ Nesse sentido já decidiu a Corte de Cassação italiana (Cass., 4 agosto 2000, $n$. 10251): "Le ordinanze del giudice istruttore, conformemente al loro carattere strumentale e alla loro funzione di regolamentazione del processo, sono sempre modificabili e revocabili, fatte salve le limitazioni ex art. 177 C.P.C., anche implicitamente con la sentenza che definisce il merito della controversia.". G. Novelli, S. PETITTI, Codice di procedura civile annotato con la giurisprudenza, Milão, Giuffrè, 2007, p. 879.
}

${ }^{302}$ Cf. art. 177 (Effetti e revoca delle ordinanze) do Codice di Procedura Civile italiano, primeira parte: "Le ordinanze, comunque motivate, non possono mai pregiudicare la decisione della causa. Salvo quanto disposto dal seguente comma, le ordinanze possono essere sempre modificate o revocate dal giudice che le ha pronunciate" e art. 279 (Forma dei provvedimenti del collegio) do mesmo dispositivo: "I provvedimenti del collegio, che hanno forma di ordinanza, comunque motivati, non possono mai pregiudicare la decisione della causa; salvo che la legge disponga altrimenti, essi sono modificabili e revocabili dallo stesso collegio, e non sono soggetti ai mezzi di impugnazione previsti per le sentenze. Le ordinanze del collegio sono sempre immediatamente esecutive". Existe exceção prevista à regra da eficácia imediata das ordenações proferidas pelo órgão colegiado: na hipótese de o colegiado, por sentenza, deixar de julgar o feito para a produção de prova, se a parte interpuser recurso contra essa decisão, aguarda-se o respectivo julgamento para então se produzir a prova.

${ }^{303}$ Cf. art. 177 (Effetti e revoca delle ordinanze) do Codice di Procedura Civile italiano, segunda parte: "Non sono modificabili né revocabili dal giudice che le ha pronunciate: 1) le ordinanze pronunciate sull'accordo delle parti, in materia della quale queste possono disporre; esse sono tuttavia revocabili dal giudice istruttore o dal collegio, quando vi sia l'accordo di tutte le parti; 2) le ordinanze dichiarate espressamente non impugnabili dalla legge; 3) le ordinanze per le quali la legge predisponga uno speciale mezzo di reclamo".

${ }^{304}$ Cf. arts. 42-50 do Codice di Procedura Civile italiano, após as modificações introduzidas pela Lei 69/2009, que modificou a natureza do pronunciamento que versa sobre a competência (de sentença para ordenação).

${ }^{305}$ Art. 186-quater (Ordinanza successiva alla chiusura dell'istruzione) do Codice di Procedura Civile italiano: "Esaurita l'istruzione, il giudice istruttore, su istanza della parte che ha proposto domanda di condanna al pagamento di somme ovvero alla consegna, o al rilascio di beni, può disporre con ordinanza il pagamento, ovvero la consegna o il rilascio, nei limiti per cui ritiene già raggiunta la prova. Con l'ordinanza il giudice provvede sulle spese processuali. L'ordinanza è titolo esecutivo. Essa è revocabile con la sentenza che definisce il giudizio. Se, dopo la pronuncia dell'ordinanza, il processo si estingue, l'ordinanza acquista l'efficacia della sentenza impugnabile sull'oggetto dell'istanza. L'ordinanza acquista l'efficacia della sentenza 
De acordo com este dispositivo, ao final da fase instrutória, a parte pode requerer a antecipação dos efeitos da tutela para a liberação de soma em dinheiro ou entrega de bens, caso em que o provimento será emitido com base em cognição exauriente e terá força de título executivo ${ }^{306}$. Esta ordinanza pode adquirir força de sentenza, se a parte contra a qual foi deferida, uma vez intimada, não manifestar, no prazo de 30 dias, sua vontade de que seja proferida sentença (por ocasião de cuja prolação a ordenação pode vir a ser modificada), hipótese em que caberá o appello $^{307}$.

Contudo, a tênue distinção entre essas duas formas de pronunciamentos que geram consequências bastante distintas (tanto do ponto de vista da possibilidade de serem impugnáveis mediante recurso, quanto em relação à sua aptidão de se estabilizarem) gera problemas na prática, que a jurisprudência concorre para resolver a partir do critério de conteúdo, mais do que de forma ${ }^{308}$.

Assim, para determinar no caso concreto se certa decisão é sentenza ou ordinanza, e, portanto, se está sujeita a algum meio de impugnação, deve-se verificar se, naquele pronunciamento, o juiz se manifestou a respeito do mérito da controvérsia ou

impugnabile sull'oggetto dell'istanza se la parte intimata non manifesta entro trenta giorni dalla sua pronuncia in udienza o dalla comunicazione, con ricorso notificato all'altra parte e depositato in cancelleria, la volontà che sia pronunciata la sentenza."

306 “Após o encerramento da fase instrutória, é igualmente possível pleitear a concessão de ordenação antecipatória. Nesta derradeira hipótese, cabível para pagamento de quantia certa, entrega de bens móveis e imóveis, a decisão se funda em cognição exauriente e só pode ser revogada na sentença. Se a parte condenada não manifestar, em 30 dias da intimação da decisão, recurso pleiteando a prolação de sentença. A ordenação se converte em sentença; por isso que nela já deve estar contida a condenação em despesas processuais.” L. E. B. PACífICO, Direito processual cit., p. 269.

307 “[L]'art. 7 del d.1. 21 giugno 1995 n. 238 che ha inserito nel codice l'art. 186-quarter, prevede che siano appellabili anche provvedimenti emessi in forma di ordinanza, ossia le ordinanze esecutive pronunciate dal giudice istruttore, su istanza di parte, una volta esaurita l'istruzione nel corso del giudizio di primo grado e nei limiti in cui si ritenga già 'raggiunta la prova' (v. più ampiamente il capitolo 22). L'ordinanza che condanna al pagamento di somme ovvero alla consegna o al rilascio di bene può infatti acquistare l'efficacia 'della sentenza impugnabile' e quindi costituire oggetto dell'appello. Tal equiparazione può aver luogo in due distinte ipotesi: nel caso di estinzione del processo, naturalmente dopo la pronuncia dell'ordinanza e in quello in cui la parte intimata abbia dichiarato di rinunciare alla pronuncia della (futura) sentenza; la rinunzia deve essere notificata all'atra parte e depositata in cancelleria e dalla data del deposito l'ordinanza acquista appunto l'efficacia della sentenza 'impugnabile'. Si tratta senza dubbio di una novità sul terreno normativo della quale occorrerà non soltanto verificare la pratica applicazione ma anche tracciarne il quadro di coordinamento sistematico.” L. P. COMOgLIO, C. FerRI, M. TARUfFO, Lezioni cit., p. 683.

${ }^{308}$ Em sentido contrário, C. MANDRIOLI afirma que: "In linea di massima, si deve ritenere che i mezzi di impugnazione concretamente proponibili sono quelli che la legge prevede per ciascun provvedimento così come esse si presenta sotto il profilo formale; salvi i casi eccezionali in cui questo aspetto formale sia soltanto apparente e quelli in cui la legge stessa consente di attribuire rilievo ala sostanza." Corso cit., p. 242. 
sobre os pressupostos processuais e condições da ação ${ }^{309}$. Dito de outra maneira, independentemente da forma, o pronunciamento judicial que contiver decisão a respeito de aspectos processuais ou substanciais da lide - ainda que não os enfrente propriamente deve ser considerado sentença ${ }^{310}$, desde que (i) no caso, o juiz tivesse a possibilidade de emitir tanto ordenação quanto sentença; e (ii) o provimento possua as características formais essenciais de existência da sentença ${ }^{311}$.

Invertendo-se o raciocínio, para que determinado pronunciamento judicial possa ser caracterizado como ordenação, é necessário que não seja apto a produzir efeitos para fora do processo ${ }^{312}$.

Do exposto, vê-se que, contra as sentenças cabe apelação e - via de regra contra as ordinanze não há recurso cabível, tendo em vista a possibilidade de serem novamente, via de regra - revogáveis pelo próprio órgão prolator, dispensando inclusive a

\footnotetext{
309 " $\mathrm{Al}$ fine di stabilire se un provvedimento abbia o meno caratteri di ordinanza o di sentenza e sia quindi o meno soggetto ai mezzi di impugnazione previsti per quest'ultima deve aversi riguardo non alla sua forma esteriore o alla denominazione datagli dal giudice che lo ha pronunziato ma all'effetto giuridico che esso e destinato a produrre Cass., 3 agosto 2011, n. 10731 talché si e in presenza di un'ordinanza quando il provvedimento dispone circa il contenuto formale delle attività consentite alle parti mentre si e innanzi ad una sentenza quando il giudice, nell'esercizio del suo potere giurisdizionale, si pronuncia in via definitiva o non definitiva sul merito della controversia o su presupposti e condizioni processuali”. G. NovelLI, S. PetitTi, Codice cit., p. 671 - grifos do original.
}

310 "Costituiscono sentenze - soggette agli ordinari mezzi di impugnazione e suscettibili, in mancanza, di passare in giudicato - i provvedimenti che, ai sensi dell'art. 279 C.P.C., contengono una statuizione di natura decisoria (sulla giurisdizione, sulla competenza, ovvero su questione pregiudiziali del processo o preliminari di merito) anche quando non definiscono il giudizio." G. NovelLi, S. PETITTI, Codice cit., p. 693 - grifos do original.

311 “In primo luogo, si è segnalato che il trattamento dell'ordinanza come sentenza è subordinato (nei caso descritti) alla condizione che il giudice, autore del provvedimento avesse la potestà di pronunciare sentenza: sicché non potrebbe mai valere come tale, ad es., l'ordinanza del giudice istruttore. Di poi, si è più volte ribadito che l'ordinanza anomala non può essere equiparata alla sentenza, riguardo all'impugnabilità, se non abbia i requisiti formali indispensabili per l'esistenza della sentenza, e particolarmente se sia sottoscritta dal solo presidente (come prevede, per le ordinanze, l'art. 134 c.p.c) anziché da tutti i giudici del collegio (come vuole, per le sentenze, l'art. 132 c.p.c.). In tal caso il provvedimento, pur avendo la 'sostanza' della sentenza, non potrebbe ad essa equivalere, poiché, come tale, sarebbe affetto da nullità assoluta, o inesistente, ai sensi dell'art. $161,2^{\circ}$ coma, c.p.c., e pertanto non sarebbe neppure soggetto alle impugnazioni previste per le sentenze." G. TARZIA, Profili della sentenza civile impugnabile - l'individuazione della sentenza, Milão, Giuffrè, 1967, pp. 68-69.

312 "Sotto un tal profilo, il provvedimento non ha il carattere della decisiorietà e della definitività quando la pronuncia spieghi i suoi effetti solo sul piano processuale, producendo la sua efficacia soltanto all'interno del processo. Conseguentemente detto provvedimento, in tali casi, non e suscettibile di impugnazione innanzi al giudice di grado superiore. (Nella specie, la S. C., in forza di detto principio, ha confermato la pronuncia di inammissibilità di un appello proposto avverso un'ordinanza avente carattere meramente ordinatorio)." G. Novelli, S. PetitTI, Codice cit., p. 672, grifos do original. 
necessidade de fato novo para a modificação da decisão ${ }^{313}$. Disso se extrai que, feitos os necessários descontos, não há preclusão para o juiz em relação às questões decididas por meio de ordenações ${ }^{314}$.

Essa sistemática representou inovação em relação ao que se tinha sob a vigência do Código de 1865, em que as decisões proferidas ao longo do processo eram sentenças interlocutórias, portanto, sujeitas à preclusão para o juiz ${ }^{315}$. Essa modificação implicou aumento dos poderes do juiz que, no regime do Código anterior - reflexo da ideologia liberal e individualista da época -, eram praticamente inexistentes ${ }^{316}$.

A comparação com o sistema italiano se mostra pertinente pois lá, como aqui, os operadores do direito têm de lidar com críticas relativas à excessiva duração do processo, até mesmo da União Europeia ${ }^{317}$. Outrossim, a solução adotada pelo ordenamento italiano no que diz respeito à preclusão de questões resolvidas por ordinanze poderia, em tese, ser importada para o Brasil caso se venha a modificar o sistema de recorribilidade das decisões interlocutórias, flexibilizando-se o procedimento em relação ao regime de preclusões - tema que se retomará no capítulo atinente à proposta de novo Código de Processo Civil.

A possibilidade de se utilizar solução existente em outro ordenamento deve ser vista sempre com as necessárias ressalvas atinentes, por exemplo, aos parâmetros para

\footnotetext{
313 "Il potere del giudice di revocare o modificare le proprie ordinanze può essere esercitato non solo per circostanze sopravvenute, ma anche per la nuova valutazione di circostanze preesistenti. Cass., 21 marzo 1977, n. 1096”. G. Novelli, S. PetitTi, Codice cit., p. 879, grifos do original.

${ }^{314}$ Nesse sentido, aliás, já se pronunciou expressamente a Corte de Cassação: "Le ordinanze emesse nel corso del giudizio, oltre che revocabili e modificabili, anche implicitamente, hanno efficacia del tutto provvisoria e non comportano alcun effetto preclusivo, con la conseguenza che il giudice del merito può giustificare nella sentenza le proprie scelte su motivi ed argomenti diversi da quelli indicati nell'ordinanza istruttoria. Cass., 31 maggio 2005, n. 11580”. G. Novelli, S. PetiTti, Codice cit., p. 879, grifo do original.

315 "Col potere di ordinanza il legislatore ha cambiato il sistema del codice di rito del 1865, basato sulle sentenze interlocutorie, preclusive del riesame delle questioni decise con esse. Infatti elemento integrante e funzionale del nuovo sistema e la revocabilità dell'ordinanza, anche nel significato di modificazione delle linee della disciplina giuridica applicabile rispetto a quella ritenuta in precedenza e sul fondamento della quale e stata emessa l'ordinanza. Cass., 15 aprile 1971, n. 1060'". G. NovelLi, S. PetitTi, Codice cit., p. 877, grifos do original.

316 “'[I]n un processo di questo tipo il giudice è privo di qualsiasi potere direttivo in ordine allo svolgimento del processo, non può in alcun modo provocare o collaborare alla determinazione del thema decidendum (dei termini effettivi della controversia) e del thema probandum (dei fatti che necessitano di prova), è privo di qualsiasi potere in ordine alla acquisizione d'ufficio delle prove al giudizio. Il giudice, praticamente, appare come un terzo che agisce solo su istanza di parte, e non solo per quanto riguarda la messa in moto del processo, ma durante tutta la 'vita' del processo stesso cui rimane sostanzialmente estraneo". A. PROTO PISANI, Appunti cit., pp. 23-24, grifos do original.
}

${ }^{317}$ Cf. P. Hoffman, Razoável duração do processo, $1^{\text {a }}$ edição, São Paulo, Quartier Latin, 2006, p. 54. 
se considerar "demorado" um determinado processo na Itália e no Brasil. Também se deve atentar para a circunstância de que certos problemas do Judiciário brasileiro - assim como ocorre na Itália - não dizem respeito à inadequação do método de trabalho propriamente, mas sim à falta de infraestrutura, pessoal e material, para lidar com o imenso volume de processos. Em relação a estes, não se deve esperar seja a promulgação de novo Código uma solução, como adiante se buscará explicar em profundidade ${ }^{318}$.

${ }^{318}$ V. infra, itens 6.3 e 7.4. 


\section{RELAÇÃo ENTRE A ORALIDAdE E A RECORRIBILIDADE DAS DECISÕES INTERLOCUTÓRIAS}

No início da Idade Moderna, o processo praticado na Europa era eminentemente escrito, sem contato do juiz com as partes, obedecia ao sistema da prova tarifária e favorecia a exploração dos jurisdicionados por profissionais forenses - o que levou a crise de confiança na justiça ${ }^{319}$. Assim, visando a adequar o método de trabalho às necessidades da vida moderna, e a resgatar a reputação do processo estatal, iniciou-se na Europa no século XIX movimento de reação que pregava a oralidade como princípio central do processo civil ${ }^{320}$.

Entretanto, a aplicação ferrenha do processo oral em diversos países europeus acabou por gerar desvios nos locais onde haviam sido implantadas reformas nessa direção, a partir de 1850. Por exemplo, narra FASCHING que "uma série de atos processuais orais transformaram-se em atos formais, que demandavam perda supérflua de tempo e custos" ${ }^{\prime 21}$, em razão da radicalização da ideia de que todas as decisões deveriam ser tomadas com base no contato direto do juiz com a prova - que, por sua vez, deveria ser produzida em audiência, forçando-se a leitura de todos os documentos que instruiriam a causa neste ato (inclusive laudos periciais) e repetição de todas as alegações que já estavam expostas em petições ${ }^{322}$.

\footnotetext{
${ }^{319}$ Conforme ensina H. W. FASCHING, "O processo nos albores do absolutismo, claudicante, escrito, mediato e reservado, conduziu a uma crise de confiança na justiça civil; a justiça converteu-se exclusivamente numa fonte de renda para profissões forenses, cujos integrantes exigiam uma posição monopolista cada vez maior. Os modelos processuais do século XVIIII serviam menos à tutela jurídica que, muito mais, que à denegação da Justiça" (sic). A posição dos princípios da oralidade e da imediação no processo civil moderno, Revista de processo, 39:1985, trad. Wanderlei de Paulo Barreto, p. 27.

${ }^{320}$ A esse respeito, novamente H. W. FASCHING: "As grandes reformas processuais do século XIX acentuaram, por isso, na Europa Central, de maneira expressiva, os princípios da oralidade e da mediação (sic). Sua concretização foi entusiasticamente saudada e mereceram na moderna ciência processualística quase o caráter de dogmas intocáveis." A posição cit., p. 27.

${ }^{321}$ A posição cit., p. 28.

${ }^{322}$ É o que observa M. CAPPELLETTI: "está atualmente claro que, com isso, um formalismo vinha-se a substituir um outro, ainda que oposto. Se outrora se entendia como acta somente aqueles atos que tivessem assumido a forma escrita, agora válidos e existentes eram considerados apenas os atos orais. Dessa forma, o quod non est in actis non est in mundo não era abolido, mas conservado, com a simples transformação do significado do substantivo: acta como atos orais, em lugar de escritos. Daí, novos inconvenientes gravíssimos, novos formalismos vazios". O valor atual do princípio da oralidade, Revista Jurídica, 297:2002, trad. Daniel Ustárroz (originalmente publicado em 1960), p. 12.
} 
O mesmo jurista observou ainda que os processos demoravam mais para terminar do que se havia inicialmente imaginado, e os juízes eram substituídos com mais frequência do que se poderia ter previsto. Nesse cenário, a observância estrita do princípio da imediação demandaria a repetição de todas as provas produzidas em audiência - o que aumentava a demora e o custo do processo judicial por razões totalmente alheias à vontade ou ao controle das partes ${ }^{323}$.

No mesmo sentido, LEO ROSENBERG narra que, esses excessos conduziram a reforma do ZPO alemão para permitir que, mediante a concordância das partes, se possa suprimir o debate oral, ainda que não por completo ${ }^{324}$.

Como se pode ver, a ideia de que, para fins de classificação, o processo deveria ser oral ou escrito conforme o papel que se desse à palavra dita à "viva voz" em audiência ou à obrigatoriedade de se deduzir alegações por escrito é relativamente recente $^{325}$. Tal concepção foi arduamente defendida por GIUSEPPE CHIOVENDA, cujos estudos, realizados no início do século XX no cenário que se procurou delinear, tiveram

\footnotetext{
323 "De um lado, mostrou-se que os processos demoravam mais tempo do que presumia o legislador, e que principalmente os juízes mudavam com maior frequência do que se supunha no princípio. Um manuseio rigoroso do princípio da imediação significava, no caso de mudança de juiz, que o novo juiz deveria repetir todo o processo até então, e também que as partes não poderiam renunciar a isto, uma vez que elas não poderiam amputar a possibilidade conhecimento da questão que lhes assegura o ordenamento jurídico. $\mathrm{O}$ resultado de um manuseio tão estrito do princípio significa que os processos se tornam mais longos e mais caros e que, principalmente, as partes não conseguem entender o porquê de, justamente o seu processo, ter que se tornar mais demorado e mais caro, em razão de uma reviravolta intrajudicial." A posição cit., p. 29.
}

324 "Las complicaciones unidas en la antigua ZPO a la aplicación ilimitada del principio de oralidad (...) conducían, en el caso de tribunales recargados, a una apariencia de oralidad, en la que los abogados, con consentimiento del tribunal, muchas veces se remitían en sus escritos a los debates anteriores, etc.; en particular, en asuntos ya debatidos varias veces, en lugar de alegar oralmente; así, el debate final se convirtió cada vez más en una simple formalidad. Por eso, el decreto del 22 de diciembre de 1923, at. V, §23a (después decreto de descargo, §7; ahora ZPO, §128, II), permite en todas las instancias que el tribunal, con consentimiento de las partes, omita el debate oral, pero no el debate por completo, pues todas las actuaciones de las partes o del tribunal, que en otro caso necesitarían la forma de debate oral, pueden y deben ejecutarse por escrito, en tanto que no se hayan cumplido en forma ora. Este 'procedimiento sin debate oral', como lo designa el $\S 8$ del decreto de descargo, no es un procedimiento exclusivamente descrito; porque también sigue siendo material procesal el contenido de un debate oral previo (...), pero no presupone debate oral." Tratado de derecho procesal civil, tomo II, v. 28, coleção Ciencia del Proceso, $1^{\mathrm{a}}$ edição, Buenos Aires, Ediciones Jurídicas Europa-América, 1955, 183 - grifo do original.

${ }^{325}$ É o que ensina CELSO NEVES: "Desde que a escrita se impôs, como técnica de representação simbólica dos fatos da vida, desapareceu dos hábitos dos povos o procedimento estritamente oral, para dar lugar ao chamado procedimento misto, de que é exemplo o formular do sistema romano do ordo iudiciorum privatorum. A distinção entre procedimento escrito e procedimento oral, essa é recente, resultante de idéias que o empenho de realizar uma estrutura ajustada aos princípios informativos do processo civil veio revelando, à medida que se penetrava o mundo dos conceitos pertinentes a essa figura da ciência jurídica." Estrutura fundamental do processo civil - tutela jurídica processual, ação, processo e procedimento, $2^{\mathrm{a}}$ edição, $2^{\mathrm{a}}$ tiragem, Rio de Janeiro, Forense, 1997, p. 275. 
ampla influência sobre as leis processuais que vieram a ser promulgadas no Brasil, a começar pelo Código de Processo Civil de 1939.

Cumpre apenas observar que, embora Alemanha, Áustria e França (segundo classificação do próprio processualista), por exemplo, já houvessem adotado o processo oral em seus ordenamentos, uma vez que o trabalho do mencionado autor italiano sobre o tema é possivelmente o que mais teve influência sobre a ordem jurídica e o pensamento de juristas brasileiros, optou-se por abordá-lo em maior profundidade na sequência.

\subsection{PROCEDIMENTO ORAL IDEALIZADO POR CHIOVENDA E O VALOR ATUAL DA SUA CONSTRUÇÃO TEÓRICA}

GiUseppe Chiovenda fez parte do grupo para estudos processuais da Comissão para o Pós-Guerra encarregado de elaborar proposta de reforma para o Código de Processo Civil italiano, que teve por foco a modificação radical do procedimento, considerado exageradamente demorado, complicado e custoso ${ }^{326}$.

Assim, visando a adequar o processo civil "à natureza e às necessidades da vida moderna" ${ }^{327}$, a partir do modelo de processo penal que lhe era contemporâneo, da constatação de que a maior parte dos Estados europeus já o fazia, e buscando resgatar o meio pelo qual se desenvolvia o processo romano, CHIOVENDA defendeu que também passasse a se reger pelo princípio da oralidade. Para ele, a ideia se justificava pois os defeitos que geravam insatisfação e necessidade de mudança eram inerentes à sua forma escrita $^{328}$.

\footnotetext{
326 “Oggetto della proposta riforma è soprattutto il procedimento. Indubbiamente l'intero Codice di procedura civile e le altre norme di contenuto processuale sparse nelle varie leggi nostre, hanno bisogno di revisione. Ma la parte a cui è più urgente provvedere à la disciplina del procedimento, perché questa è la più profondamente difettosa, e perché nel metodo del procedimento, come quello da cui dipendono i caratteri essenziali di ogni processo, hanno radice gl'inconvenienti più gravi che si deplorano nell9andamento delle nostre liti, quali la esagerata complicazione, l'interminabile durata e il costo enorme." Saggi di diritto processuale civile (1900-1930), v. 2, nova edição, consideravelmente aumentada, Roma, Foro Italiano, 1931, p. 3.

${ }^{327}$ Instituições cit., p. 68.

328 "Poiché il nostro processo è sostanzialmente un processo scritto e i difetti che più si lamentano in esso sono i difetti propri del processo scritto". G. CHIOvENDA, Saggi cit., v. 2, p. 4.
} 
Segundo seu raciocínio, somente não se havia até aquele momento adotado modelo de procedimento oral para o processo civil em razão de, nesse campo, a oralidade não se apresentar como princípio político, mas sim técnico-jurídico, não tendo, portanto, contado com o "caloroso interesse das massas, mas somente com a fria e calculada adesão dos estudiosos, dos praxistas, dos homens de governo" ${ }^{\text {229. }}$.

Na sua concepção, a observância da oralidade - denominação sintética para representar um conjunto de ideias ${ }^{330}$ - pressupunha a observância concomitante dos seguintes princípios: (i) prevalência da palavra ("viva voz") dita em audiência como meio de expressão; (ii) imediação; (iii) identidade física do juiz; (iv) concentração; e (v) irrecorribilidade em separado das decisões interlocutórias.

Sua aplicação conjunta conduziria a um processo mais célere - pois desenvolvido em uma única audiência, ou em poucas audiências sucessivas -, com decisão mais aderente à realidade - pois o juiz estaria em contato direto com as partes, as testemunhas, e as provas.

Outras vantagens seriam a redução "de dois terços, pelo menos" 331 , no número de atos judiciais praticados; a diminuição do número de incidentes e impugnações, decorrentes da simplificação e da concentração dos atos; a redução das possibilidades de recorrer em razão da proibição de impugnar separadamente as decisões interlocutórias; maior objetividade da causa, pela supressão das ações incidentais autônomas, que implicaria também na redução do volume de trabalho dos magistrados; e a possibilidade de utilização do juiz delegado para as situações em que não fosse indispensável a colegialidade ${ }^{332}$.

A aplicação desse modelo de processo evidentemente pressupunha o efetivo desenvolvimento do processo a partir de debates orais realizados diante do órgão julgador, destacando o processualista italiano ser, para este fim, no mais das vezes, supérflua a

\footnotetext{
${ }^{329}$ G. CHIOVENDA, Instituições cit., v. 3, pp. 71-72.

330 “Il nome stesso di oralità, assunto per la necessità d'esprimere con una formula semplice e rappresentativa un complesso d'idee e di caratteri, può generare equivoci, se non si analizzano i principii distinti, per quanto strettamente collegati fra loro, che sono contenuti in questa formola e che danno al processo orale il suo particolare aspetto". G. CHIOvENDA, Saggi cit., v. 2, p. 27.

${ }^{331}$ G. ChIOVENDA, Instituições cit., v. 3, p. 86.

${ }^{332}$ Cf. G. ChiovendA, Instituições cit., v. 3, pp. 86-87.
} 
discussão oral em ambiente no qual as partes sejam obrigadas a apresentar também por escrito suas deduções, por não passar de mera repetição ${ }^{333}$.

Sua preocupação e comprometimento com a ideia de processo oral foram tais que refutou as possíveis críticas à adoção desse modelo, afirmou que a aplicação do princípio poderia ser flexibilizada de acordo com a situação de direito material que se apresentasse ao Poder Judiciário ${ }^{334}$, e analisou as implicações da adoção desse modelo sobre a função judicial - nesse aspecto, argumentando pela possibilidade de aumento dos poderes do juiz ${ }^{335}$.

Como se vê, a oralidade preconizada por GiUsepPe ChiovendA representava um complexo de ideias que visava a alterar as bases do procedimento escrito até então vigente na Itália, modificando o modo como o juiz interagia com as partes, colhia a prova e decidia. A reforma que desejava implantar decorria da sua convicção pessoal de que o sistema processual italiano precisava de reforma profunda - e não apenas de pequenos ajustes ou retoques - para que pudesse corresponder às expectativas dos jurisdicionados e também se adequar à contemporaneidade ${ }^{336}$.

O método proposto serviria para alcançar decisão mais justa (por ter sido obtida a partir do contato direto do juiz com as partes e as provas), mais célere e por meio menos custoso.

As ideias de que (i) o procedimento oral seria tão adequado no âmbito civil como no penal, (ii) o Estado moderno tem o dever de assegurar a razoável duração do processo - onde quer que venha a se desenvolver, quer seja em pequenas cidades ou em grandes metrópoles; e (iii) o processo que mescla elementos escritos e orais tem vantagens

\footnotetext{
333 "Num sistema em que as partes são obrigadas a expor por escrito não só as declarações e os pedidos, mas ainda 'os motivos de fato e de direito em que se apoiam os pedidos' (Cod. Proc. Civ., art. 162 e 167; reg. ger. jud., art. 221), a discussão oral reduz-se em regra a uma repetição supérflua.” G. CHIOvENDA, Instituições cit., v. 3, p. 75 .

334 "Non bisogna credere poi che il processo orale sia d'una struttura immobile e fissa, da doversi applicare fino alle estreme conseguenze logiche in ogni caso e per ogni controversia." E explica: "se l'oralità in talune applicazioni dovesse produrre danni maggiori dei vantaggi il principio teorico dovrà esser sacrificato all'utilità pratica." Saggi cit., v. 2, p. 36.

335 "Occorre dunque assicurare al giudice una posizione che lo renda partecipe ativo nel rapporto processuale e munirlo dell'autorità necessaria per esercitarvi la sua funzione." G. CHIOvENDA, Saggi cit., v. 2, p. 39.

336 "Il processo italiano non è soltanto complicato, lunghissimo e costoso: è anche un vecchio arnese, affatto difforme dalle condizione del tempo presente ed in contrasto stridente con l'indole della funzione pubblica a cui è destinato, quale essa appare allo spirito moderno." G. CHIOvEndA, Saggi di Diritto Processuale Civile (1900-1930), v. 1, nova edição, consideravelmente aumentada, Roma, Foro Italiano, 1930, p. 369.
} 
sobre o modelo totalmente escrito, bem sintetizadas por EDUARDO AUGUSTO GARCÍA ${ }^{337}$, faziam com que a oralidade fosse alçada ao nível de superprincípio regulador do procedimento como um todo, de alguma forma semelhante ao que hoje ocorre com o devido processo legal.

Anos depois, valendo-se do distanciamento crítico que o transcurso do tempo lhe propiciava, MAURO CAPPELLETTI coerentemente observou que o movimento reformista pela oralidade refletia uma violenta reação contra um tipo de processo que já estava ultrapassado do ponto de vista cultural e sociológico ${ }^{338}$, caracterizado, em suma, pela (i) prevalência absoluta do elemento escrito sobre o oral; (ii) falta de imediação; (iii) aplicação do método da prova legal; e (iv) falta de concentração no desenvolvimento do processo $^{339}$

Mas, como toda reação, esta também se sujeitou ao risco de exageros despropositados, em que acabou se perdendo. Para CAPPELLETTI, a coexistência mais proveitosa entre o elemento oral e o escrito passaria utilização da escrita para (i) a propositura da demanda (fatos, fundamentos e pedido); e (ii) argumentação jurídica, sem prejuízo de eventuais debates orais ${ }^{340}$. Apoiando-se no próprio CHIOVENDA, ele afirma que o campo "no qual o princípio da oralidade podia e devia mais propriamente operar era justamente o das provas" ${ }^{\prime 31}$.

E, diante de seu próprio questionamento a respeito da existência de um valor "atual" para a oralidade (lembrando que se trata de texto escrito há mais de quarenta anos), CAPPELLETTI responde que, nos países como Itália, em que a ideia-base da oralidade

\footnotetext{
${ }^{337}$ Cf. La oralidad en el processo civil, in Antología Jurídica - cuadernos mensuales, 264:1940.

338 “Au delà des exagérations et des fanatismes originaires et de quelques dogmatismes ou malentendus persistant, elle a signifié la critique d'une forma de procédure désormais culturellement et sociologiquement surannée, et l'effort d'en faire disparaître les défauts les plus graves." Procedure orale et procedure écrite, Milão, Dott. A. Giuffrè, 1971, p. 60.

${ }^{339}$ Assim se resumem as características mencionadas, cf. o ensaio L'oralità nel processo civile italiano: ideale contro realtà in Giustizia e società, v. 11 da coleção Diritto e Cultura Moderna, $1^{\mathrm{a}}$ reimpressão da $1^{\mathrm{a}}$ edição, Milão, Edizioni di Comunità, 1977: (i) "predominio, o addirittura vero e proprio monopolio, dell'elemento scritto rispetto a quello orale" (p. 131); (ii) "mancanza di immediatezza. Ogni contatto personale e diretto del giudice con le parti, i testi, gli esperti e le altre fonti di prova (luoghi, cose), era vietato o, per lo meno, scoraggiato" (pp. 131-132); (iii) "regole astratte e aprioristiche determinavano l'ammissibilità delle prove (p. 132); e (iv) "lo svolgimento del processo mancava di ogni concentrazione; si trattava, infatti, di un procedimento diviso in una lunga serie di piccole tappe e fase, con l'impulso processuale rimesso quasi esclusivamente alla discrezione delle parti, anzi dei loro difensori” (p. 133) - todos os grifos do original.
}

${ }^{340}$ Cf. O valor atual cit., pp. 13-14.

${ }^{341} O$ valor atual cit., p. 14. 
jamais foi posta em prática por meio de reformas processuais, o princípio segue tendo duplo valor: de um lado, representa um programa de modificações para a concretização de um processo mais rápido, concentrado, eficiente; de outro, um processo mais fiel a metodologia concreta e empírico-indutiva na descoberta dos fatos e na apreciação das $\operatorname{provas}^{342}$.

Substancialmente de acordo, analisando o pensamento de CHIOVENDA mais recentemente, CAVALLONE afirma que suas ideias poderiam ser resumidas num "teorema", segundo o qual o aspecto da imediação do princípio da oralidade seria condição indispensável para uma correta aplicação do princípio da livre valoração da prova ${ }^{343}$.

A respeito, JOSÉ BONET NAVARRo ressalta ainda que a prática do procedimento oral exige mais dos profissionais que atuam no processo em termos de formação jurídica e preparação efetiva para o caso, bem como investimentos para possibilitar a realização e documentação adequada dos $\operatorname{atos}^{344}$. Mas, para ele, ainda assim a oralidade é mais eficiente em relação aos aspectos da celeridade e da qualidade da decisão ${ }^{345}$.

Mas, para CAPPELLETTI, a oralidade possui destacado valor atual também em relação a outro aspecto, qual seja, a socialização do direito em geral, e do processo em especial. Em consequência desse fenômeno, pelo qual as camadas mais baixas da população também passam a ter acesso ao Poder Judiciário, por vezes sem estarem assistidas por advogados, o juiz deve ter papel ativo na condução do processo, auxiliando a

342 “(...) le sens de procédure orale est double: d'une part procédure plus rapide, concentrée, efficiente, de l'autre procédure plus fidèle à une méthodologie concrète et empirico-inductive dans la recherche des faits et dans l'appréciation des preuves." Procédure orale cit., p. 92 - grifos do original.

343 “(...) l'oralità, sotto lo specifico profilo dell'immediatezza, è condizione indispensabile per una corretta applicazione del principio della libera valutazione delle prove; nel 'processo scritto' i giudizio di fatto è invece inevitabilmente frutto dell'applicazione di criteri di valutazione 'apriotistici, formali, convenzionali', come quelli che caratterizzavano il c.d. sistema della prova legale nel processo romano-canonico e comune." Forme del procedimento e funzione della prova (ottant'anni dopo Chiovenda), Rivista di diritto processuale, 2:2006, p. 418 - grifos do original.

${ }^{344} \mathrm{Cf}$. Un aporte en el debate sobre la conveniencia de la oralidad especialmente en la práctica de la prueba in La prueba en el proceso civil - cuestiones fundamentales, Madri, Difusión, 2009, pp. 59-60.

345 "Con una valoración de conjunto, y sin negar algunas cualidades de la escritura, la oralidad se presenta como más eficiente especialmente en lo relativo a la celeridad y a la calidad de la resolución, sin que suponga necesariamente una merma en la garantía de los derechos respecto de la que permite la escritura. Ciertamente es más exigente. Y cuando no se cumplan sus requerimientos, podrá presentarse como ineficiente al frustrarse sus ventajas. Incluso en supuestos puntuales, dada su mejor exigencia, puede presentarse la escritura como un sistema más adecuado. Pero nada de ello permite afirmar que con carácter general o de principio la escritura se más adecuada. La escritura podrá serlo en algún supuesto puntual y, en general, ha de representar solamente el remedio último." Un aporte cit., p. 62. 
formulação dos pedidos, administrando a produção da prova, tendo contato direto com as $\operatorname{partes}^{346}$.

\subsubsection{PRINCÍPIOS FUNDAMENTAIS DO PROCESSO ORAL SEGUNDO GIUSEPPE CHIOVENDA}

No processo oral, prevaleceria como forma de expressão a palavra dita oralmente sobre a escrita, que então desempenhava duplo papel de preparar a causa e registrar (documentar) os atos executados oralmente ${ }^{347}$. Essa é a primeira e mais marcante característica desse tipo ideal, consubstanciada no chamado princípio da "prevalência da palavra como meio de expressão combinado com uso de meios escritos de preparação e de documentação" 348 .

Evidente, assim, que o próprio CHIOVENDA não propunha a adoção de um procedimento puramente oral. Diferentemente, reconhecia que todos os processos atualmente contêm um misto entre oralidade e escritura, sendo que o que diferencia processos orais de escritos para fins classificatórios é a maior ou menor importância que se dá à palavra dita a viva voz, ou transcrita em papel.

No procedimento por ele idealizado, a petição inicial escrita deveria ser ajuizada perante o juízo competente, indicando-se os elementos da demanda e as provas que o autor pretendesse produzir, de modo a permitir o exercício do direito de defesa pelo réu. $\mathrm{O}$ conteúdo dessa peça era, porém, considerado apenas o "anúncio das declarações a

\footnotetext{
346 "En d'autres termes, à partir de la phase préparatoire du procès, le juge assume un tâche active et d'assistance par rapport aux parties, en discutant avec celles-ci la meilleure formulation des demandes et des exceptions, collaborant à la recherche de la vérité, en somme coopérant pour que la victoire soit du côté de la partir qui a réellement raison, et non pas de celle qui pourrait prévaloir grâce à ses moyens financiers ou à sa plus grande habileté personnelle ou à celle de son défenseur. Il s'agit, comme le souligne le rapporteur yougoslave, d'un phénomène de démocratisation de la procédure civile, par lequel 'le tribunal est accessible aussi aux parties non instruites, voire illettrées." E conclui: "Dans une telle conception sociale de la procédure, l'importance du contact direct et personnel, et partant oral, du juge avec les parties n'a pas besoin d'être démontrée, pas plus que les risques d'autoritarisme, d'arbitraire et d'abus qu'elle entrâine." Procédure orale cit., pp. 93-94.

${ }^{347}$ A esse respeito, J. M. OTHON SIDOU: "o processo oral não induz desprezo pelo elemento escrito, ademais porque, depois que a escrita substituiu as pantomimas e as fórmulas certis verba, é impossível idear-se um processo não gráfico, que o protocolize e, assim, o perenize." A recepção da oralidade no sistema processual brasileiro, Revista do Curso de Direito da Universidade Federal de Uberlândia, Uberlândia, 14:1985, p. 276 - grifo do original.

${ }^{348}$ G. CHIOVENDA, Instituições cit., v. 3, p. 74.
} 
fazer-se na audiência"349, de tal sorte que, na audiência, se poderia acrescentar, suprimir ou remodelar alegações.

Segunda característica do processo oral era a "imediação da relação entre o juiz e as pessoas cujas declarações deve apreciar" ${ }^{\prime 350}$, ou seja, que o juiz estivesse em contato com as partes, e presente na produção das provas, para que pudesse julgar de acordo com suas próprias impressões imediatas, e não baseado em relatos de terceiros.

Até mesmo como decorrência desses princípios, postulou-se também pela "identidade das pessoas físicas que constituem o juiz durante a condução da causa", terceiro subprincípio que compõe a oralidade, que implica na necessidade de o julgador que colhe a prova ser o mesmo que decide a demanda, sob pena de o processo oral perante o juiz instrutor se tornar escrito perante o julgador.

Ainda, para que os princípios acima elencados fossem viáveis, previa-se a concentração do conhecimento da causa numa única audiência, ou em poucas audiências sucessivas. A ideia era, de um lado, facilitar a manutenção da identidade física do juiz, e, de outro, viabilizar que a decisão fosse tomada a partir das nítidas impressões do juiz em audiência, sem que houvesse tempo para que se confundissem ou turvassem.

Em sua campanha, CHIOVENDA reconhecia a possibilidade de flexibilização da oralidade de acordo com as necessidades de direito material de cada caso, a depender do tipo de controvérsia e de provas necessárias para resolvê-la ${ }^{351}$. Também tinha consciência de que o modelo processual que idealizava favorecia a posição do juiz como representante do órgão estatal central no processo ${ }^{352}$.

Por fim, previa-se como último corolário a irrecorribilidade em separado das decisões interlocutórias de que adiante se tratará.

\footnotetext{
${ }^{349}$ G. CHIOVENDA, Instituições cit., v. 3, p. 77 - grifo do original.

${ }^{350}$ G. CHIOVENDA, Instituições cit., v. 3, p. 78.

351 "Se a oralidade em certas aplicações tivesse de produzir maiores prejuízos que vantagens, deveria sacrificar-se o princípio teórico à utilidade prática." E prossegue: "nem sempre a oralidade terá a mesma importância. O valor da oralidade consiste essencialmente naquele de seus poliédricos aspectos que se conhece por imediação, ou seja, naquele que permite utilizar na apreciação das provas a observação direta." G. CHIOvENDA, Instituições cit., v. 3, p. 88 - grifos do original.

352 "De um lado, a restaurada importância do livre convencimento do juiz, de outro o renovado conceito da jurisdição como função do Estado, restituíram ao juiz, no processo moderno, uma posição central de órgão público interessado em ministrar justiça pelo modo melhor e mais pronto possivel." G. CHIOVENDA, Instituições cit., v. 3, p. 91.
} 


\subsubsection{IRRECORRIBILIDADE EM SEPARADO DAS DECISÕES INTERLOCUTÓRIAS COMO COROLÁRIO DO PROCESSO ORAL}

Um dos subprincípios que compunham o processo oral idealizado por Chiovenda era, como já se adiantou, a irrecorribilidade em separado das decisões interlocutórias.

A ideia é autoexplicativa e consiste na impossibilidade de impugnar autonomamente os pronunciamentos judiciais que versassem sobre questões incidentes no curso do processo, viabilizando o prosseguimento do debate - vital para que ao final da audiência se possa ter uma decisão a respeito do mérito da demanda.

Dessa forma, importante ressalvar que há dois tipos de exceções que poderiam ser opostas na audiência: as que dizem respeito ao mérito e as que impedem o julgamento do mérito (litis ingressum impedientes). Estas fogem à regra da irrecorribilidade em separado das decisões interlocutórias, por versarem sobre questões em que, a critério do juiz, se possa reputar mais adequado aguardar o julgamento do recurso para prosseguir ${ }^{353}$.

Importante lembrar que o subprincípio da irrecorribilidade em separado das decisões interlocutórias somente poderia ser corretamente compreendido e aplicado no contexto de processo oral que também observasse as ideias de concentração, imediação e identidade física do juiz - até porque, se assim fosse, o processo teria curtíssima duração, se comparado, por exemplo, com o modelo brasileiro atual. Nesse contexto, não haveria prejuízo substancial para a parte decorrente de esperar a prolação da sentença definitiva para então impugnar a decisão interlocutória ${ }^{354}$.

\footnotetext{
353 " La oralidad y la concentración exigen que la decisión del incidente no sea impugnable separadamente del fondo. La inapelabilidad de las interlocutorias es una regla que no debe abandonarse sino para algunas excepciones litis ingressum impedientes, cuando el juez crea conveniente suspender la continuación del pleito hasta que se decida sobre la apelación." Principios cit., tomo II, p. 136.

${ }^{354}$ Nesse sentido, P. CALMON: "Para a exata compreensão do tema é indispensável pensar com CHIOvENDA, para quem oralidade é um conjunto de ideias; e como formam um conjunto, as ideias não podem ser vistas e muito menos aplicadas isoladamente. Oralidade representa uma soma de ideias: política de autocomposição + concentração + contraditório + imediação + participação do juiz + informalidade + plena condução do processo pelo juiz de primeiro grau. Ora, adotados todos esses elementos, a consequência natural é que não haverá oportunidade par o recurso imediato das decisões interlocutórias". O modelo oral de processo no século XXI, disponível em http://direitoprocessual.org.br, acesso em 12.3.2012, p. 18 - grifos do original.
} 
Portanto, a irrecorribilidade em separado das decisões interlocutórias somente seria útil e justificável do ponto de vista das garantias das partes num cenário em que o dano decorrente do prosseguimento da marcha processual até a prolação da sentença fosse menor do que o que eventualmente pudesse advir da suspensão do procedimento em primeiro grau de jurisdição para o julgamento do recurso contra a decisão interlocutória.

A reflexão a respeito da aplicabilidade desse princípio deve, assim, se focar na composição entre esses dois tipos de prejuízo que em tese poderiam decorrer da decisão interlocutória, como advertiu o próprio CHIOVENDA, após ter observado a deturpação de suas ideias em leis que vieram a ser promulgadas na Itália ${ }^{355}$.

\subsubsection{COMPATIBILIZAÇÃO ENTRE OS PRINCÍPIOS DA IRRECORRIBILIDADE EM SEPARADO DAS DECISÕES INTERLOCUTÓRIAS E DO DUPLO GRAU DE JURISDIÇÃO}

A interposição de recurso - meio pelo qual se instrumentaliza o princípio do duplo grau de jurisdição - prejudica diretamente alguns dos corolários do processo oral, como a imediação, a concentração e a identidade física do juiz, o que fica bastante evidente, por exemplo, quando o recurso ataca decisão proferida com base em prova colhida diretamente pelo julgador em primeiro grau.

Sem prejuízo, entende-se ser possível a compatibilização do princípio da irrecorribilidade em separado das decisões interlocutórias com o duplo grau de jurisdição pela previsão de recurso único por instância, de modo que o ataque a eventual decisão interlocutória se daria, por exemplo, na forma de preliminar do recurso destinado a impugnar sentença.

Para tanto, duas opções um tanto distintas em termos de preclusão se apresentariam de maneira mais evidente: (i) admitir-se que o próprio juiz prolator da decisão interlocutória venha a revê-la, mesmo de ofício, até a prolação da sentença abolindo-se a preclusão de questões; ou (ii) permitir que as partes possam, no momento da

\footnotetext{
355 “(...) a proibição de apelação imediata das interlocutórias é compreensível e útil na medida em que constitúa (sic) uma partícula do processo oral, quer dizer, um adminículo indispesavel (sic) para assegurar a concentração. Fora daí é desarrazoado e prejudicial.” E prossegue: “(...) trata-se de encontrar uma composição entre os danos que ao processo oral poderia acarretar a suspensão do curso da causa à espera de tornar-se definitiva a interlocutória, e os danos que, ao revés, poderiam decorrer do prosseguimento de uma causa fundada em provisões ainda sujeitas a reforma." Instituições cit., vol. 3, p. 322.
} 
apelação, rediscutir todas as decisões que foram proferidas no curso do processo em primeiro grau - flexibilizando-se o momento da alegação do inconformismo.

Essa ideia, conquanto possa compatibilizar os princípios em primeiro grau de jurisdição, não afastaria o problema de que o procedimento em segundo grau de jurisdição é eminentemente escrito, não havendo contato dos julgadores com as partes nem sua interferência direta na colheita das provas, como observa ORESTE LASPRO ${ }^{356}$.

Em outras palavras, os benefícios decorrentes de acentuada oralidade em primeiro grau se perdem com a interposição de recurso, pois a decisão que prevalece (em razão do efeito substitutivo dos recursos) não foi tomada a partir do contato direto dos julgadores com as partes, tampouco das suas impressões diretas a respeito das provas. Esse é um dos possíveis motivos de desvios que se têm verificado na prática, como a degeneração do segundo grau a um juízo de revisão da decisão impugnada a partir de suas próprias proposições ${ }^{357}$.

Nesse cenário, forçoso reconhecer que a compatibilização entre os princípios da oralidade e do duplo grau de jurisdição não é possível a partir de modificação apenas no procedimento em primeiro grau de jurisdição (por exemplo, mediante o estabelecimento da irrecorribilidade em separado das decisões interlocutórias), pois se o processo oral é considerado mais adequado, então logicamente deveria ser observado também - e principalmente, em razão da substituição - em nível recursal.

Estabelecida essa premissa, resta evidente que a total compatibilização entre os princípios demandaria a repetição, em grau de recurso, das provas produzidas em

\footnotetext{
356 “(...) se de um lado o sistema processual garantiu a oralidade como mecanismo de efetividade da justiça (...), por outro autorizou que da decisão nascida dessa oralidade coubessem recursos para tribunais, que julgam em caráter substitutivo, e por meio de um procedimento escrito. Salvo melhor juízo, esses dois sistemas acabam, portanto, se contrapondo e, mais do que isso, anulando o procedimento oral, na medida em que, quando da última decisão e, portanto, a mais importante, não existe a imediação, a identidade física do juiz, nem tão pouco a concentração." Oralidade cit., p. 53.

${ }^{357}$ É o que observa E. RICCI, ao afirmar, embora sem dados estatísticos a embasar suas conclusões, tomando por base, portanto, apenas a experiência, que "il secondo giudice o si trova di fronte ala necessità di compiere un'istruzione nuova, per la presenza di nuove istanze delle parti o l'esigenza di assumere prove che ritiene a torto rifiutate in prime cure: nel qual caso abbandona la sostanza del mero riesame; o tende a fidarsi dell'apprezzamento dei fatti contenuto nella sentenza appellata, occupandosi soprattutto del profilo giuridico della controversia." E conclui: "[i]n quest'ultimo caso, l'appello diventa altra cosa da quella che vorrebbe essere, assumendo struttura inidonea a realizzare lo stesso modello del doppio grado: il quale nella prassi ha dunque uno spazio ancora minore di quello reso palese dalle norme, e rischia di apparire all'operatore del diritto come uno schema privo di contenuto." Doppio grado cit., p. 8.
} 
primeiro grau, com aumento do tempo necessário para o julgamento definitivo - o que, naturalmente, exigiria alteração na lei $^{358}$.

Essa, contudo, não parece ser uma solução viável à vista de todos os valores que têm de ser prestigiados pelo processo, uma vez que é evidente o prejuízo para a efetividade, em decorrência da demora, e mesmo para a segurança, pois não é possível garantir que as provas poderão ser reproduzidas, devido ao transcurso do tempo.

Possivelmente por isso, o sistema processual brasileiro atual opta por afastar a oralidade em segundo grau de jurisdição, a partir de uma visão mais moderna do princípio da imediação - expressa pela sua prescindibilidade à luz da economia processual $^{359}$-, e valorizando, nesse momento, outros princípios que regem o processo.

\subsection{Oralidade no Processo Civil Brasileiro}

A viabilidade de se implantar a oralidade foi amplamente debatida no Brasil, tendo em muito influenciado o conteúdo do Código de Processo Civil de 1939. A título exemplificativo, CANABARRo REICHARDT narra que quando das discussões que antecederam a promulgação do Código de Processo Civil do Distrito Federal em 1924, houve posicionamentos favoráveis e contrários à adoção do procedimento oral, tendo, contudo, prevalecido o procedimento escrito em razão do voto contrário do então Ministro da Justiça ${ }^{360}$.

BILAC PINTO informa que, após a promulgação da Constituição de 1934, que outorgou à União a competência para legislar sobre matéria processual, iniciaram-se as

\footnotetext{
${ }^{358}$ Substancialmente de acordo, O. N. S. LASPRO: "o sistema oral (no que se refere naturalmente à consecução de sua finalidade) e o duplo grau de jurisdição (em que a segunda decisão prevalece sobre a primeira) não podem coexistir, diante de uma flagrante incompatibilidade. Se o segundo juiz julga com base no que está transcrito, não há oralidade; não se permite à parte recorrer no tocante aos fatos, não há duplo grau de jurisdição." Alguns aspectos dos recursos no juizado especial cível, Revista do Advogado, 50:1997.

${ }^{359}$ De acordo com H. W. FASCHING, a "visão hodierna do princípio da imediação" "exprime uma dicotomia: a) o reconhecimento da fundamental igualdade de valor das coletas de provas de todos os processos judiciais, e bb) que o princípio da imediação é um princípio prescindível, acerca de cuja utilização as partes podem dispor livremente. Demais disso, este princípio inclui-se no arcabouço geral da economia processual, uma vez que através da sua limitação pode o processo ser essencialmente barateado e agilizado." A posição cit., p. 32 .

${ }^{360}$ Cf. A reforma do Processo Civil - oralidade e concentração - contribuição ao $1^{\circ}$ congresso nacional de Direito Judiciário, Rio de Janeiro, Officinas Graphicas d'A Noite, 1936, p. 11.
} 
discussões para a promulgação de Código de Processo Civil para todo o país, que poderiam ser divididas em duas fases: (i) de 1934 a 1937: a reforma tinha caráter eminentemente técnico e objetivava apenas a unificação do direito adjetivo; e (ii) 1937-1938: reforma de contornos políticos, com intensa campanha em favor da oralidade ${ }^{361}$. Na opinião dele, o procedimento oral seria o mais adequado a atender aos reclamos da sociedade da época por uma "justiça acessível e rápida" ${ }^{362}$, tanto nas grandes capitais como nas cidades do interior.

Os defensores dessa ideia advogaram que a supressão dos recursos em face das decisões interlocutórias poderia trazer duas ordens de vantagens: de um lado, reduzir a duração do processo e, de outro, evitar a interposição de recursos com fins meramente protelatórios $^{363}$. Por outro lado, não haveria, ao menos em princípio, para os defensores da ideia de procedimento oral, desvantagem na supressão desses recursos, vez que se permitiria às partes recorrer posteriormente da decisão interlocutória ${ }^{364}$.

De modo mais específico, a irrecorribilidade em separado das decisões interlocutórias, disse-se, também contribuiria para que o juiz deixasse de ser mero espectador do processo, favorecendo o aumento dos seus poderes, aspecto que se considerava importante para a efetivação das vantagens do processo oral em sua plenitude $^{365}$.

Outro argumento apresentado favorável à adoção da oralidade dizia respeito à inaptidão do procedimento escrito então vigente para atingir os ideais de justiça com

\footnotetext{
${ }^{361}$ Cf. O sentido da reforma, Revista Forense, 74:1938, p. 152.

${ }^{362}$ O sentido cit., p. 153.

${ }^{363}$ Cf. H. C. REICHARDT, A reforma cit., "Os incidentes no curso da demanda são a causa das delongas nos processos. A supressão dos recursos nas sentenças interlocutórias, traria uma dupla vantagem: encurtaria a duração da causa e acabaria com a chicana." A reforma cit., p. 41 - grifo do original.

${ }^{364}$ Cf. F. MORATO: "este ultimo requisito da irrecorribilidade das interlocutórias tende por egual a assegurar a actuação dos primeiros, impedindo que os julgamentos se dilatem, concentrando a causa e abreviando o tempo para sua decisão. No que não ha nenhum sacrifício da justiça, porque se por um lado se obsta a que as demandas se retardem com incidentes, por outro se ampara os direitos dos pleiteantes, permitindo que os dictos incidentes sejam apreciados com o julgamento de subtancia." A oralidade, Revista Forense, 74:1938, p. 145 - mantida a grafia original da época.

365 “A irrecorribilidade das decisões interlocutórias, e o incremento dos poderes do juiz, transformando-o de simples espectador inérte em verdadeiro dominus litis, são pressupostos dêste principio." L. MACHADO GuIMARÃES, O processo oral e o processo escrito, Revista Forense, 74: 1938, p. 166 - grifo do original; mantida a grafia original da época.
} 
rapidez e segurança que se esperava do processo, em razão da natural demora que decorre da escrita e também da ausência de contato com as partes ou a colheita das provas $^{366}$.

Essas ideias nortearam o espírito do Código de Processo Civil de 1939, que acolhia a oralidade no tocante à recorribilidade das decisões interlocutórias. Com efeito, previa-se apelação para impugnar sentenças que versassem sobre o mérito da causa (sentenças definitivas, de acordo com o art. 820); agravo de petição para desafiar sentenças que extinguissem o processo sem resolução de mérito (sentenças terminativas, conforme art. 846); agravo de instrumento e agravo no auto do processo para impugnar as decisões interlocutórias taxativamente previstas nos arts. 842 e 851, respectivamente. As demais decisões interlocutórias eram irrecorríveis e poderiam ser revistas pelo próprio juiz prolator.

Com isso, houve a valorização do princípio da oralidade, mas o sistema era confuso e impreciso. Além das dificuldades inerentes à definição do conceito de "mérito" que implicariam no cabimento do recurso de agravo de petição ou apelação, o elenco casuístico das hipóteses de cabimento dos agravos no auto do processo ou de instrumento se revelou insuficiente para abranger todas as situações em que as decisões interlocutórias seriam suscetíveis de causar prejuízo imediato às partes.

Como consequência, houve a multiplicação de sucedâneos recursais, como o mandado de segurança contra ato judicial e a correição parcial, desviados de suas finalidades originárias para a impugnação de decisões interlocutórias. Ou seja, embora atendesse à oralidade em teoria, o sistema era ineficiente do ponto de vista da irrecorribilidade em separado das decisões interlocutórias ${ }^{367}$.

\footnotetext{
${ }^{366}$ Foi o que observou P. B. MARTINS, que ressaltou que "[o] processo escrito, pelo seu cunho formalistico, não póde resolver o problema da rapidez. Com êle, o destino das lides forenses é eternizar-se." Entretanto, "[s]em contácto com o processo, estranho á produçãoo das provas, privado da faculdade de dirigir a instrução, o juíz só toma conhecimento da casa quando, muito tempo depois de sua propositura, os autos lhe vão conclusos para proferir sentença. Tendo os autos se avolumado à sua revelia, em consequência de uma série infindável de incidentes, quasi sempre maliciosamente provocados, o juiz não poderá sem muito esfôrço, reflexão e estudo inteirar-se cumpridamente da questão de fato e fixar, em consequência, a regra jurídica que deverá aplicar. É por isso que mesmo bons juízes, ou deixam os processos se acumularem ou proferem muitas vezes sentenças em que são considerados fatos ou circunstâncias acidentais, com prejuizo das questões essenciais." E conclui: "o processo escrito, portanto, não atende aos requisitos de segurança e rapidez." Sôbre o Projéto de Codificação do Processo Civil e Comercial, Revista Forense, 74:1938, p. 168 mantida a grafia original da época.

${ }^{367}$ T. PARÁ FILHO explica que o Código de Processo Civil de 1939 atendeu ao princípio da irrecorribilidade das decisões interlocutórias "mediante enunciado estritamente casuístico" das hipóteses em que se admitia recurso. "Isto permitiu-lhe limitar a recorribilidade das interlocutórias, mas teve o inconveniente de deixar
} 
Com o Código de 1973, houve mitigação da oralidade "a fim de atender a peculiaridades da extensão territorial do país"368. Para tentar simplificar o sistema recursal e evitar a utilização anômala de outros remédios processuais no lugar de recursos, o Código de Processo Civil atual previu que das sentenças, fossem terminativas ou definitivas, caberia apelação, e das decisões interlocutórias caberia agravo (inicialmente, somente por instrumento, depois retido). Essa previsão, embora tenha sem dúvida alguma contribuído para a simplificação do sistema recursal, deixa completamente de lado o subprincípio da irrecorribilidade das decisões interlocutórias ${ }^{369}$.

A despeito disso, entende-se que o processo civil brasileiro privilegia a oralidade em relação aos atos de conciliação, saneamento, instrução e debates ${ }^{370}$, estando alinhado às modernas tendências a respeito do tema $\mathrm{a}^{371-372}$.

em aberto casos nos quais, embora em jogo esta ou aquela regra técnica de processo, há, ou pode haver, inegável repercussão material sobre o direito das partes, através de decisão desse tipo." E conclui: "Com efeito, despachos ou decisões tais podem afetar, sumamente, a posição ou a esfera jurídica das partes, mesmo fora do elenco das hipóteses expressamente previstas. Foi por isso que se vulgarizou tanto a prática das reclamações ou correições, como sucedâneo de recurso". A recorribilidade das decisões interlocutórias no novo Código de Processo Civil, obtido em www.rtonline.com.br, originalmente publicado em Revista de Processo, 5:1977, p. 15 e seguintes, p. 2 (arquivo eletrônico).

${ }^{368}$ A. BuZAID, Exposição de motivos do Código de Processo Civil (Lei no $5.869 / 1973$ ).

369 “A aplicação deste princípio entre nós provou que os litigantes, impacientes de qualquer demora no julgamento do recurso, acabaram por engendrar esdrúxulas formas de impugnação. Podem ser lembradas, a título de exemplo, a correição parcial e o mandado de segurança. Não sendo possível modificar a natureza das coisas, o projeto preferiu admitir agravo de instrumento de todas as decisões interlocutórias. É mais uma exceção. O projeto a introduziu para ser fiel à realidade da prática nacional.” A. BuZAID, Exposição de motivos do Código de Processo Civil de 1973 (Lei no 5.869/1973).

${ }^{370}$ Cf. J. C. GUEDES: “'”(...) o conceito de oralidade (procedimento oral) migrou de uma visão pragmática e purista para outra intermediária, identificada com o principio da oralidade, enquanto fonte de subprincípios, para a final, identificar-se hoje com o procedimento por audiências. Este último estágio conceitual da oralidade pode ser identificado na audiência preliminar ou prévia, introduzida no procedimento comum ordinário (art. 331 do CPC) e no procedimento comum sumário (art. 277 do CPC)”. O princípio da oralidade - procedimento por audiências no Direito Processual Civil Brasileiro, v. 53, coleção Estudos de Direito de Processo Enrico Tullio Liebman, São Paulo, Revista dos Tribunais, 2003, p. 91.

${ }^{371}$ Essa é a opinião de J. M. ОтноN SIDOU, para quem "[e]nfileira o Brasil, inquestionavelmente, e hoje mais que no regime de 1939, por conduto do Código de 1973, as nações que praticam a oralidade processual." $A$ recepção cit., p. 281.

Mais recentemente, O. N. S. LASPRO também afirmou: “(...) o sistema processual brasileiro, em linhas gerais, tem adotado um procedimento oral dentro das tendências mais modernas, em que se restringe a oralidade aos atos processuais ligados a instrução e debates, onde, efetivamente, se mostra eficaz o procedimento, adaptando-o, contudo, à realidade de um país de extensão bastante grande, cuja população, na maior parte muito humilde, necessita de um procedimento simplificado sob pena do formalismo do processo deixar de ser uma garantia das partes, mas um fim em si mesmo em detrimento da justiça." Oralidade cit., p. 52.

${ }^{372}$ Em sentido contrário, A. P. GRINOVER: “(...) a praxe e a mentalidade dominantes autorizam a conclusão de que hoje o procedimento brasileiro é verdadeiramente do tipo escrito, quer pela prevalência da palavra escrita sobre a falada, quer pelas rigorosas restrições aos corolários próprios da oralidade." Aspectos constitucionais cit., p. 14. 


\subsection{JUSTIÇA do TrABALHO}

Os conflitos de interesses no âmbito do Direito do Trabalho são regidos por regras próprias previstas na Consolidação das Leis do Trabalho, que permite aplicação apenas subsidiária das regras do Código de Processo Civil. Da mesma forma, as ações são processadas e julgadas em tribunais próprios dessa justiça especializada ${ }^{373}$.

Para compreender a existência de diferenças entre o sistema de recursos no processo trabalhista se comparado ao processo civil e as razões de tais distinções, convém lembrar que à Justiça do Trabalho toca oferecer resposta aos litígios entre empregador e empregado, partes que, via de regra, não possuem condição financeira semelhante, sendo que ordinariamente para uma delas a ação tem caráter alimentar ${ }^{374}$.

Assim, o instrumento foi adaptado de modo a se adequar às características dos conflitos que lhe seriam submetidos, que demandavam - pode-se argumentar que com maior urgência do que os conflitos cíveis, justamente em razão da natureza alimentar das causas - tramitação simples e solução rápida ${ }^{375}$.

\footnotetext{
373 “A Justiça do Trabalho brasileira sempre se revelou autônoma no sentido dos órgãos de justiça comum ou de qualquer outra não terem interferência em seus processos e decisões (...). Desde, porém, que se criou a Justiça do Trabalho, com o Decreto-Lei $\mathrm{n}^{\circ} 1.237$ e sucessiva legislação especializada, sòmente os órgãos próprios da Justiça do Trabalho tiveram competência para julgar os dissídios laborais, em primeira e segunda instância, bem como executar suas próprias decisões, com a mesma fôrça e autoridade da justiça comum". A. Mendonça Lima, Recursos Trabalhistas, tomo I, coleção Philadelpho Azevedo, São Paulo, Max Limonad, 1956, pp. 144-145 - mantida a grafia original da época.

${ }^{374}$ Nesse sentido a lição de A. MASCARO NASCIMENTO: "O processo de dissídio individual não pode ser demorado, arrastando-se interminavelmente perante os órgãos judiciais, porque a matéria versada é, basicamente, de natureza alimentar, como os salários etc. Assim, propugna-se por um processo de dissídio individual rápido, o quanto possível simples e informal, para que possa desenvolver-se com maior rapidez." Entretanto, o mesmo professor observa: "A CLT não se afastou desse objetivo, porém é deturpada sua aplicação." Curso de direito processual do trabalho, $17^{\mathrm{a}}$ edição, ampliada e atualizada, São Paulo, Saraiva, 1997, p. 289.

375 "A Justiça do Trabalho, por sua índole e finalidade, deve orientar-se por normas que assegurem simplicidade, brevidade e gratuidade. Competindo-lhe a solução de controvérsias em que as partes, via de regra, não possuem igualdade social, sobretudo no plano econômico, a complexidade, a lentidão e o encarecimento das formas processuais tornariam êste organismo especial do Poder Judiciário uma inutilidade, com efeitos contraproducentes, acirrando a luta violenta das classes, antes de ser um ambiente de concórdia e de equilíbrio.” A. MENDONÇA LIMA, Recursos cit., tomo I, p. 149 - mantida a grafia original da época.
} 
O Processo do Trabalho é marcado pela acentuada oralidade se comparado ao Processo Civil ${ }^{376}$, com a concentração dos atos em audiência e a irrecorribilidade das decisões interlocutórias ${ }^{377}$.

Neste sistema, o agravo é expressa e taxativamente previsto como exceção, sendo cabível em três modalidades ${ }^{378}$ : (i) de petição, das decisões proferidas em sede de execução; (ii) de instrumento, das decisões que denegarem a interposição de recursos, conforme art. 897 caput, alíneas e parágrafos da Consolidação das Leis do Trabalho; e (iii) regimental, contra decisão do relator que no Tribunal Superior do Trabalho, tenha negado seguimento a recurso sem apoio em súmula.

O estudo dos agravos previstos no processo do trabalho, contudo, revela que essas figuras não guardam exata correspondência com o recurso de agravo previsto no Código de Processo Civil. Com efeito, o agravo de petição - que no sistema do Código de Processo Civil de 1939 se destinava a impugnar sentença terminativa - é por excelência o recurso a ser interposto contra as decisões proferidas em sede de execução na Justiça do Trabalho. Seu procedimento é semelhante ao do recurso ordinário previsto na CLT ou ao do recurso de apelação, havendo duplo juízo de admissibilidade e remessa dos autos ao órgão ad quem para julgamento do recurso ${ }^{379}$.

\footnotetext{
376 "São princípios orientadores do processo trabalhista: oralidade — porque a maioria dos atos processuais se realiza oralmente; concentração - que veda a interposição de recurso em decisões interlocutórias, excluídas as que são terminativas do feito; impulso judicial — que admite a execução da sentença promovida de oficio pelo juiz; conciliação - de caráter obrigatório, sob pena de o processo ser declarado nulo; contraditório - que enseja a manifestação das partes em todas as fases do processo; convencimento racional do julgador - que manda o juiz decidir em vista dos ele- mentos reunidos nos autos; e instrumentalidade das formas processuais — que veda a anulação de atos processuais que não acarretem qualquer prejuízo à parte ou que possam ser repetidos.” E. G. SAAD, CLT Comentada, $34^{a}$ edição, revista e ampliada por José Eduardo Saad e Ana Maria Saad Castello Branco, São Paulo, LTr, 2004, p. 533.

${ }^{377}$ S. P. MARTINS explica que "[n]o processo do trabalho, não cabe agravo de instrumento para qualquer decisão interlocutória. (...) Mesmo das decisões de exceção de suspeição ou de incompetência, não caberá recurso, apenas da decisão definitiva, salvo em se tratando de decisão que venha a terminar o feito na Justiça do Trabalho, como a do juiz que se julga incompetente em razão da matéria, em que caberá recurso, porque aí se considera definitiva a decisão ( $\$ 2^{\circ}$ do art. 799 da CLT). Direito processual do trabalho - doutrina e prática forense, $28^{\mathrm{a}}$ edição, São Paulo, Atlas, 2008, p. 391.

378 "Ensinam os doutrinadores que a enumeração dos recursos admissíveis no processo trabalhista, contida no art. 893 da CLT, é taxativa: esgotando as possibilidades, não deixa lacuna a ser preenchida pela invocação subsidiária do Código de Processo Civil. Em outros termos: não há omissão da CLT, em matéria de arrolamento dos recursos cabíveis, mas exclusão intencional dos não arrolados.” W. D. GiGLIO, Direito processual do trabalho, $10^{a}$ edição revista e ampliada, São Paulo, Saraiva, 1997.
}

${ }^{379}$ Cf. M. A. TeIXeIRA FILHo, Sistema dos Recursos Trabalhistas, $9^{\text {a }}$ edição, atualizada de acordo com a Lei n. 9.139/95, São Paulo, LTr, 1997, pp. 314-315. 
Já o agravo de instrumento previsto no processo do trabalho tem por escopo unicamente destrancar recurso cujo seguimento tenha sido negado em sede de juízo de admissibilidade $^{380}$, possuindo, assim, finalidade específica, distinta das que se pode atribuir ao agravo de instrumento no processo civil.

Sergio Pinto Martins relata que se tem adotado a prática de consignar em ata de audiência os protestos em face das decisões interlocutórias proferidas no ato, de maneira relativamente semelhante ao que ocorre com o agravo retido oral previsto pelo art. 523 do Código de Processo Civil. No entanto, para ele, esses protestos não possuem valor jurídico, em razão da inexistência de previsão legal de recurso em face de decisão interlocutória $^{381}$. Em sentido contrário, FrANCISCO FERREIRA JORGE NETO e JOUBERTO DE Quadros Pessoa CAVAlCANTE, para quem a não consignação do protesto (ou a ausência de manifestação a respeito do inconformismo na primeira oportunidade de manifestação) gera preclusão ${ }^{382}$.

Seja como for, na Justiça do Trabalho, ante a inexistência de remédio processual para impugnar decisões interlocutórias suscetíveis de causar às partes prejuízo imediato, verifica-se que a prática tem encontrado meios para promover a sua revisão, mediante a utilização de sucedâneos recursais com o mandado de segurança e a correição parcial $^{383}$.

\footnotetext{
380 "O agravo de instrumento trabalhista não tem a feição do recurso com o mesmo nome na justiça comum. É, apenas, um meio de obstar que a instância a quo prive a superior de conhecer de um recurso interposto." A. Mendonça Lima, Recursos trabalhistas, tomo II, coleção Philadelpho Azevedo, São Paulo, Max Limonad, 1956, p. 289.

381 “Inexiste o agravo retido no processo do trabalho nem mesmo para efeito de veiculação de nulidades. Na prática, costuma-se adotar a veiculação dos protestos em ata de audiência. entendo, porém, que esses protestos não existem, porque não há disposição na lei que verse sobre o tema. É comum, contudo, na Justiça do Trabalho, consignar-se em ata tais protestos, quando uma das partes não concorda com uma determinação do juiz." Direito processual do trabalho cit., p. 458.

382 “A insatisfação da parte expressa por escrito ou forma verbal em audiência, não tem natureza jurídica de recurso, mas de mera impugnação não preclusiva da matéria que poderá ser suscitada em recurso próprio." $\mathrm{E}$ prosseguem: "Por isso, a não impugnação da decisão em primeira oportunidade enseja a preclusão". Direito processual do trabalho, tomo II, $4^{\mathrm{a}}$ edição, Rio de Janeiro, Lumen Juris, 2009, p. 976.

${ }^{383}$ É o que informa J. L. SOUTO MAIOR: "Na legislação trabalhista brasileira a irrecorribilidade das interlocutórias é preceito absoluto, mas acabam surgindo formas alternativas para essa impugnação - vide o mandado de segurança contra decisões dessa natureza, com pleno prejuízo para a efetividade do processo. Com efeito, nessas situações, há integral desvirtuamento de conceitos processuais, pois de modo algum os atos praticados pelo juiz representam abuso de autoridade ou desvio de poder, que pudesse justificar a interposição do writ." Procedimento oral: um pressuposto da efetividade do processo do trabalho, tese (doutorado em Direito do Trabalho), Faculdade de Direito - Universidade de São Paulo, São Paulo, 1997, pp. 128-129.
} 


\subsection{JuIZAdos EsPeciais CíVEIS}

A promulgação da Lei 7.244/1984, que instituiu os juizados de pequenas causas, teve por motivação, em primeiro lugar, criar instrumento para a efetivação da garantia do acesso à justiça para as pessoas mais humildes, aliviando a chamada "litigiosidade contida" dos conflitos de interesses que deixavam de ser solucionados ${ }^{384}$. Ademais, buscou-se também tentar resolver o litígio em estágio inicial de seu desenvolvimento, antes que viesse a se expandir, tomando proporções que demandariam dispêndio ainda maior de recursos por parte do Estado ${ }^{385}$.

Após período relativamente curto de vigência daquela, sobreveio a Lei 9.099/1.995, que dispôs sobre os Juizados Especiais Cíveis. Em ambas as leis, previu-se a irrecorribilidade das decisões interlocutórias, mediante a instituição de um único recurso por instância, após a prolação de sentença ${ }^{386}$. Essa é também a regra geral contida na Lei 10.259/2001, que trata dos Juizados Especiais Federais Cíveis, embora esta última admita expressamente exceção relativamente aos provimentos cautelares que podem ser deferidos pelos juízes para evitar dano de difícil reparação ${ }^{387}$.

\footnotetext{
${ }^{384} \mathrm{~K}$. WATANABE, autor da expressão, explica que nas grandes cidades o relacionamento interpessoal é cada vez mais impessoal, o que dificulta a atuação de mediadores naturais de conflitos, como "parentes, amigos, líderes de comunidade, autoridades eclesiásticas". Por isso, parte desses conflitos fica "completamente sem solução, muitas vezes até pela renúncia total do direito pelo prejudicado. É o que podemos denominar de 'litigiosidade contida', fenômeno extremamente perigoso para a estabilidade social, pois é um ingrediente a mais na 'panela de pressão' social, que já está demonstrando sinais de deteriorização do seu sistema de resistência ('quebra-quebra' ao atraso dos trens, cenas de violência no trânsito e recrudescimento de outros tipos de violência." Filosofia e características básicas do Juizado Especial de Pequenas Causas in K. Watanabe (coord.), Juizado Especial de Pequenas Causas (Lei 7.244, de 7 de novembro de 1984), São Paulo, Revista dos Tribunais, 1985, p. 2.

${ }^{385}$ C. R. Dinamarco, explicou que a Lei das Pequenas Causas "visou, acima de tudo, a tornar efetiva a promessa solene de prestação do serviço jurisdicional feita pelo Estado-de-direito brasileiro em sede constitucional (Const., art. 153, $\S 4^{\circ}$ ). Ela quis eliminar resíduos representados pela não-efetivação dessa promessa constitucional em relação a pessoas humildes e suas causas modestas, além de permitir que o serviço jurisdicional apresente resultados úteis ao solucionar prontamente os conflitos, antes que eles se expandam e cheguem a incomodar mais do que é aceitável. O desafogo dos órgãos judiciários, relacionado com as causas que presentemente lhes são trazidas, não constituiu objetivo a motivar a nova legislação." Manual das pequenas causas, $1^{\mathrm{a}}$ edição, São Paulo, Revista dos Tribunais, 1986, p. 2. No mesmo sentido, A. G. CARneiro, Juizado de pequenas causas in C. R. Dinamarco, A. P. Grinover, K. Watanabe (coords.), Participação e processo, $1^{\mathrm{a}}$ edição, São Paulo, Revista dos Tribunais, 1988, p. 341.

${ }^{386}$ Art. 41 da Lei 9.099/1995: "Da sentença, excetuada a homologatória de conciliação ou laudo arbitral, caberá recurso para o próprio Juizado."

${ }^{387}$ Art. $5^{\circ}$ da Lei 10.259/2001: "Exceto nos casos do art. $4^{\circ}$, somente será admitido recurso de sentença definitiva."
} 
Dessa forma, no âmbito dos juizados especiais, existe a possibilidade de recurso sem efeito suspensivo em face da sentença (excetuadas as sentenças que homologam transação ou laudo arbitral) para turmas formadas por três juízes togados atuantes em primeiro grau de jurisdição ${ }^{388}$, ou seja, sem a remessa ao Tribunal de Justiça ou Tribunal Regional Federal para julgamento, conforme art. 41 da Lei 9.099/1995 ${ }^{389}$. Aliás, para CÂNDIDO DinAMARCO, esse é um traço que diferencia o recurso inominado da apelação prevista para o processo civil comum: seu caráter de retratação, por ser julgado por órgão que na realidade não está funcionalmente destacado apenas para esta função ${ }^{390}$.

O inconformismo é, portanto, ordinariamente, julgado no âmbito do próprio juizado, sem a interferência de qualquer outro órgão do Poder Judiciário ${ }^{391}$, e para o recurso as partes deverão necessariamente estar representadas por advogado, independentemente do valor da causa ${ }^{392}$.

Trata-se de tentativa de compatibilizar o princípio da oralidade que rege o procedimento dos juizados especiais cíveis, tanto em nível estadual quanto federal ${ }^{393}$, com

\footnotetext{
388 "Quando os respectivos diplomas legais estabelecem que das decisões proferidas pelos juizados cabe recurso às Turmas Recursais (Lei 9.099/1995, art. 41, $\S 1^{\text {o; }}$, Lei 10.259/2001, art. 21), os quais serão integrados por juízes em exercício no primeiro grau de jurisdição, reunidos na sede do Juizado, quer dizer que "existe a possibilidade de novo julgamento mas por juízes do mesmo grau", o que, segundo o autor, configuraria exceção ao princípio do duplo grau de jurisdição. M. J. NOGUEIRA, Duplo grau de jurisdição: aspectos constitucionais e reflexos processuais, in L. FUX, N. NERY JR., e T. A. A. WAMBIER (coords.), Processo e Constituição - Estudos em homenagem ao Professor José Carlos Barbosa Moreira, São Paulo, Revista dos Tribunais, 2006, p. 543.

${ }^{389}$ Art. 41 da Lei 9.099/1995: "Da sentença, excetuada a homologatória de conciliação ou laudo arbitral, caberá recurso para o próprio Juizado. $\S 1^{\circ} \mathrm{O}$ recurso será julgado por uma turma composta por três Juízes togados, em exercício no primeiro grau de jurisdição, reunidos na sede do Juizado.” Na lei 10.259/2001, vide também art. 21: "Art. 21. As Turmas Recursais serão instituídas por decisão do Tribunal Regional Federal, que definirá sua composição e área de competência, podendo abranger mais de uma seção".

390 "Não se trata de um órgão ad quem diferenciado e destacado do órgão que já julgou a causa, mas dele próprio, em outra composição. O novo julgamento a que o recurso visa tem, com isso, nítido caráter de juizo de retratação, como sucede tradicionalmente com os embargos infringentes do direito luso-brasileiro." Manual cit., p. 98.

${ }^{391}$ Conforme ensina C. R. DinAmarCo, a competência dos juízes de primeiro grau do próprio juizado em turmas recursais é funcional, não podendo, portanto, ser derrogada por convenção das partes. Cf. Manual cit., p. 30.

${ }^{392}$ Art. 41, $\S 2^{\circ}$, da Lei 9.099/1995: "No recurso, as partes serão obrigatoriamente representadas por advogado."

${ }^{393}$ Art. $2^{\circ}$ da Lei 9.099/1995: "O processo orientar-se-á pelos critérios da oralidade, simplicidade, informalidade, economia processual e celeridade, buscando, sempre que possível, a conciliação ou a transação". Art. 1 da Lei 10.259/2001: "São instituídos os Juizados Especiais Cíveis e Criminais da Justiça Federal, aos quais se aplica, no que não conflitar com esta Lei, o disposto na Lei no 9.099, de 26 de setembro de 1995."
} 
o princípio do duplo grau de jurisdição, mediante a previsão de um meio de impugnação das decisões judiciais que, contudo, não é imediatamente exercitável ${ }^{394}$.

Em consonância com as ideias de GIUSEPPE CHIOvenda a respeito da irrecorribilidade em separado das decisões interlocutórias já expostas, a motivação para a supressão de recurso equivalente ao agravo de instrumento decorreu, de um lado, do reduzido número de decisões interlocutórias a serem proferidas de acordo com o desenho procedimental dos Juizados Especiais, e de outro, do pouco tempo que as partes teriam de aguardar até que fosse proferida sentença - para cuja impugnação se previu meio próprio ${ }^{395}$ - em razão da concentração dos atos processuais em audiência.

Nesse microssistema, a disposição de um recurso único por instância se revela coerente também com a possibilidade de as partes não serem assistidas por advogados nas causas cujo valor não exceda 20 salários mínimos vigentes, admitindo-se que aquele que eventualmente vier a ser prejudicado por decisão interlocutória pode sair vencedor após a prolação da sentença.

Fosse o caso de impugnar imediatamente a decisão interlocutória sob pena de preclusão $0^{396}$, como ocorre na Justiça Comum, a parte teria de contratar advogado para a elaboração do recurso, necessidade que poderia acabar se desvirtuando em uma de duas situações: (i) ou se deixaria de impugnar a decisão interlocutória pela impossibilidade de contratar advogado no exíguo prazo do recurso (supondo-se dez dias, pela aplicação analógica do prazo para agravo do Código de Processo Civil ou mesmo do prazo para recurso inominado dos Juizados Especiais); ou (ii) se reduziria drasticamente o número de pessoas que procuram o Juizado desassistidas de advogado - ferindo-se o propósito de acesso amplo à Justiça que norteou sua criação, pois se formaria a consciência de que a contratação seria inevitável em algum momento da marcha processual.

\footnotetext{
${ }^{394}$ Para M. LORENCINI, “[a] introdução dos juizados especiais cíveis no ordenamento jurídico brasileiro e a sistemática por ele sugerida não arranhou o princípio do duplo grau”. Juizado Especial Cível: o direito processual revisitado, dissertação (mestrado em Direito Processual), Faculdade de Direito do Largo Universidade de São Paulo, São Paulo, 2002, 106.

395 “Não há recurso contra decisão interlocutória no processo das pequenas causas. E essa negativa assim radical tornou-se possível, aliás, em face da grande redução das interlocutórias nesse processo e da rapidez com que, após alguma que eventualmente se dê, a sentença vem a ser pronunciada.” C. R. DiNAMARCO, Manual cit., p. 99.

${ }^{396}$ A respeito, por todos, R. L. TUCCI, “em virtude da inadmissibilidade de interposição de recurso contra decisão interlocutória, a matéria nesta versada não restará coberta pela preclusão, podendo ser reiterada na impugnação de sentença, com o escopo de sua reapreciação pelo órgão colegiado ad quem." Juizado especial de pequenas causas (anotações à Lei n. 7.244, de 7-11-1984, 1ª edição, São Paulo, Saraiva, 1985, p. 247.
} 
O não cabimento de agravo de instrumento em face de decisão interlocutória proferida no curso do procedimento do Juizado Especial Cível consta do enunciado $n^{\circ} 15$ do Fórum Nacional dos Juizados Especiais (FONAJE), em que se lê: "Nos Juizados Especiais não é cabível o recurso de agravo, exceto nas hipóteses dos artigos 544 e 557 do CPC" ${ }^{\prime 397}$. Pelo referido enunciado, caberiam agravos apenas em face das decisões do relator que inadmitem recurso extraordinário ou negam seguimento a recurso manifestamente inadmissível, improcedente, prejudicado, ou em confronto com súmula ou jurisprudência dominante do Colégio Recursal ou dos Tribunais Superiores.

Ocorre, porém, que na prática os agravos em face de decisões interlocutórias proferidas em juizados especiais cíveis têm sido admitidos, reconhecendose a competência da Turma Recursal para seu processamento e julgamento ${ }^{398}$, ainda que não unanimemente. Disso são evidências os posicionamentos firmados em enunciados dos Colégios Recursais de São Paulo - em que se admite agravo de instrumento contra decisão suscetível de causar à parte lesão de difícil reparação $0^{399}$ - e do Rio de Janeiro - em que não se admitem agravos de instrumento ${ }^{400}-$, invocados a título exemplificativo.

397 Redação modificada no XXI Encontro - Vitória/ES, $\quad$ disponível em http://www.fonaje.org.br/2012/?secao=exibe_secao\&id_secao=6, acesso em 15.11.2012.

398 “JUIZADO ESPECIAIS CÍVEL. DECISÃO INTERLOCUTÓRIA. AGRAVO DE INSTRUMENTO. COMPETÊNCIA. TURMA RECURSAL. 1 - Cabe à Turma recursal e não ao Tribunal de Justiça julgar agravo de instrumento tirado de decisão singular do juiz que julga deserta apelação por insuficiência de preparo. 2 - Os juizados especiais e os colegiados recursais respectivos não tem relação de subordinação recursal com os Tribunais de Justiça. 3 - Conflito conhecido para declarar competente o Segundo Colégio Recursal dos Juizados Especiais Cíveis de São Paulo - Foro Regional I - Santana - SP.” (STJ, 2a seção, conflito de competência $n^{\circ}$ 104.476/SP, rel. min. Fernando Gonçalves, j. 27.5.2009)

${ }^{399}$ É esse o entendimento consolidado firmado em encontros do Primeiro Colégio Recursal dos Juizados Especiais Cíveis da Capital (do Estado de São Paulo) e de Juízes de Juizados Especiais e Colégios Recursais, conforme enunciado $n^{\circ}$ 2: "É admissível, no caso de lesão grave e difícil reparação, o recurso de agravo de instrumento no Juizado Especial Cível”. Comunicado expedido pelo Conselho Superior da Magistratura, publicado em $\quad 9.12 .2008, \quad$ disponível $\quad \mathrm{em}$ https://esaj.tjsp.jus.br/gcnPtl/abrirDetalhesLegislacao.do?cdLegislacaoEdit=52803\&flBtVoltar=N, acesso em 15.11.2012.

${ }^{400}$ No Colégio Recursal Cível do Rio de Janeiro não se admite a interposição de agravo de instrumento em face de decisão interlocutória. O entendimento consolidado está contido no enunciado 11.5 do aviso 23/2008, que trata da consolidação dos enunciados jurídicos cíveis e administrativos em vigor resultantes das discussões dos encontros de juízes de Juizados Especiais Cíveis e Turmas Recursais do Estado do Rio de Janeiro: "AGRAVO DE INSTRUMENTO - INADMISSIBILIDADE - No sistema de Juizados Especiais Cíveis, é inadmissível a interposição de agravo contra decisão interlocutória, anterior, ou posterior à sentença." Disponível em http://www.tjrj.jus.br/web/guest/institucional/juizespeciais/documentos/enunciados, acesso em 15.11.2012. 
A justificativa teórica para essa aceitação reside em que, diferentemente do desenho procedimental que havia sido rascunhado ${ }^{401}$, o que se verifica no dia-a-dia é que o procedimento não contempla a oralidade acentuada ${ }^{402}$, razão pela qual por vezes entre a prolação de decisão interlocutória (que pode inclusive ser antecipatória de tutela) e de sentença transcorre-se período considerável, que não se poderia exigir da parte que aguardasse $\mathrm{e}^{403}$.

Invoca-se, outrossim, a possibilidade de aplicação subsidiária do Código de Processo Civil aos Juizados Especiais para admitir o agravo de instrumento interposto contra decisão interlocutória no âmbito dos Juizados Especiais Cíveis ${ }^{404}$.

A resistência no estado do Rio de Janeiro em relação à interposição de agravos, de um lado, e a flexibilização observada em São Paulo bem demonstram que os objetivos pretendidos pelo sistema ao promulgar novas leis dependem também de condições materiais e da vontade dos julgadores para que venham a ser atingidos, ideia que se buscará aprofundar no momento oportuno.

\footnotetext{
${ }^{401}$ Para observações acerca das condições dos Juizados Especiais Cíveis verificadas na prática, vide M. T. SADEK, Juizados Especiais: um novo paradigma in C. A. SALLES (coord.), As grandes transformações do Processo Civil Brasileiro - Homenagem ao Professor Kazuo Watanabe, $1^{a}$ edição, São Paulo, Quartier Latin, 2009, pp. 417-430, especialmente pp. 426-429.

402 “(...) sabe-se que a diferença existente entre o foro e a teoria muitas vezes é abismal, sem contar que situações como essas que ora analisamos frequentemente irão envolver decisões interlocutórias de mérito de natureza emergencial, podendo acarretar, dependendo do caso, consequências que envolvam dano irreparável ou de difícil reparação a qualquer dos litigantes, seja em face da concessão ou em razão da negativa da medida pleiteada.” F. C. TOURINHO NETO, J. D. FIGUEIRA JÚNIOR, Juizados Especiais Federais Cíveis e Criminais (Comentários à Lei 10.259, de 10.07.2001), $2^{\mathrm{a}}$ edição revista, atualizada e ampliada, São Paulo, Revista dos Tribunais, 2007, p. 288.
}

${ }^{403}$ Argumentando pela admissibilidade do agravo de instrumento em face de decisão interlocutória que "versar sobre o mérito, em casos de tutela de urgência (concessiva ou denegatória), e a decisão puder causar gravame ao interessado em decorrência da impiedosa incidência do 'tempo' no processo, ou se a hipótese versar a respeito de óbice a processamento de recurso ou meio de impugnação", J. D. FIGUEIRA JÚNIOR sustenta que "a regra da irrecorribilidade das decisões serve apenas para as interlocutórias proferidas dentro do segmento representado pela instrução oral, posto que se fundamenta na razão de ser da própria concentração da audiência". Manual dos juizados especiais cíveis estaduais e federais, $1^{a}$ edição, São Paulo, Revista dos Tribunais, 2006, p. 277 - grifos do original.

${ }^{404}$ Art. 92 da Lei 9.099/1995: "Aplicam-se subsidiariamente as disposições dos Códigos Penal e de Processo Penal, no que não forem incompatíveis com esta Lei." 


\subsection{CONCLUSÃO PARCIAL}

O exame do modelo de processo oral proposto por GIUSEPPE CHIOvENDA revela que a mudança que o processualista italiano propôs era bastante radical e profunda. Muito mais do que o meio de comunicação a ser utilizado, queria-se modificar a relação das partes com o juiz, a postura do julgador em relação à demanda que lhe era submetida a apreciação, além de simplificar o procedimento e diminuir sensivelmente o lapso temporal transcorrido entre o ajuizamento da ação e a prolação de sentença-

Essa ideia reverberou no Brasil, tendo sido fonte de inspiração para o Código de Processo Civil de 1939, e também para o Código atualmente vigente, embora de maneira já mitigada.

A análise da Justiça do Trabalho e da disciplina dos Juizados Especiais Cíveis, em que se buscou acentuar a oralidade, demonstra que a previsão legislativa de modelo mais próximo do tipo ideal imaginado por CHIOVENDA, por si, não é suficiente para conferir ao processo as vantagens que se imaginou teria sobre o processo escrito.

No que toca ao objeto deste estudo especificamente, o que se nota é que à irrecorribilidade das decisões interlocutórias deve estar associada a curta duração do processo, sob pena de as partes buscarem meios de afastar as primeiras, ainda que não previstos em lei. 


\section{PreocupaÇão CoM A EFETIVA ENTREga da TUTELA JURisdicional EM TEMPO RAZOÁVEL}

\subsection{Processo Civil de Resultados}

A ideia de que o processo civil é um método de trabalho, ou mecanismo estatal de solução de controvérsias destinado a fazer realizar coercitivamente a norma de direito material que deveria ter sido espontaneamente respeitada não parece mais encontrar resistência entre os estudiosos da matéria ${ }^{405}$.

Sua formulação contém em si a noção de que, sendo instrumento, o processo deve propiciar condições para que o direito violado possa ser restaurado - o que implica na avaliação de seus resultados a partir de paradigmas que lhe são exteriores, em razão da necessária e desejada projeção para fora dos autos dos efeitos dos pronunciamentos judiciais emitidos no seu bojo.

Trata-se do estágio atual de bem conhecida evolução metodológica no modo de encarar o processo civil (da qual não se tratará mais do que tangencialmente): num primeiro momento, a percepção do processo se dava apenas empiricamente, como extensão do direito civil - a que correspondeu a chamada fase sincretista ${ }^{406}$. Posteriormente,

\footnotetext{
${ }^{405}$ Famosa a definição de F. CARNELUTTI: "A palavra processo serve, pois, para indicar um método para a formaçação ou para a aplicação do direito que visa a garantir o bom resultado, ou seja, uma tal regulação do conflito de interesses que consiga realmente a paz e, portanto, seja justa e certa: a justiça deve ser sua qualidade superior ou substancial; a certeza, sua qualidade exterior ou formal; se o direito não é certo, os interessados não sabem; e se não é justo, não sentem o que é necessário para obedecer." Instituições cit., v. 1, p. 72.

${ }^{406}$ Tratando da definição de Celsus segundo a qual "actio est jus quod sibi debeatur in judicio persequendi", C. R. Dinamarco explica que "esse é um conceito de extremo sincretismo, no qual se mostra impossível distinguir o que é o direito ao bem e o que é o direito a haver proteção judiciária do direito a ele. Ignora qualquer distinção entre fenômenos jurídico-materiais e outros que pertençam ao mundo do processo. Ter actio em relação a determinado bem, tanto quanto ter pretensão a ele, significa ter direito a havê-lo pela via judicial. Por isso mesmo que sincrético, o conceito de pretensão pertence ao segmento históricometodológico que antecedeu a independência científica do direito processual." Tutela jurisdicional, obtido em www.rtonline.com.br, originalmente publicado em L. R. WAMBIER e T. A. A. WAMBIER (coords.), Doutrinas Essenciais de Processo Civil, v. 1, São Paulo, Revista dos Tribunais, 2011, pp. 907 e seguintes, p. 10 (arquivo eletrônico). A observação foi feita no contexto de que "[a]ssim entendido, o conceito de pretensão guarda alguma similitude com o de direito à tutela jurisdicional em sua visão concreta postulada no presente estudo. (...) Mas o conceito de tutela jurisdicional é bem mais amplo que o de pretensão e abrange também a proteção recebida pelo demandado mediante o exercício da jurisdição." Tutela jurisdicional cit., pp. 10-11 (arquivo eletrônico).
} 
compreendeu-se que o processo correspondia a relação diferenciada, pela qual se buscava obter um tipo especial de proteção do estado, a tutela jurisdicional, pugnando-se pela sua completude em si próprio, com seus princípios e normas, durante a fase conhecida como autonomista $^{407}$.

Por fim, chegando ao momento atual, ou instrumentalista, entende-se o processo como "método que privilegia a importância dos resultados da experiência processual na vida dos consumidores do serviço jurisdicional" ${ }^{408}$ - daí então falar-se de processo civil de resultados ${ }^{409}$.

Já há algum tempo, portanto, está fora de dúvida que, embora possua seus próprios escopos político, social e jurídico ${ }^{410}$ - que o tornam instrumento ético -, o processo deve também e principalmente servir ao direito material ${ }^{411}$.

Nessa perspectiva, a forma prescrita para a realização de certos atos é fator de organização do procedimento e garantia para as partes contra eventual arbítrio do juiz ${ }^{407}$ A postura autonomista foi "marcada pelo reconhecimento da existência dos dois ramos do direito e pela
renovação dos estudos processuais". J. R. S. BEDAQUE, Nulidade processual e instrumentalidade do
processo, obtido em www.rtonline.com.br, originalmente publicado em Revista de Processo, 60:1990, pp. 31
e seguintes, p. 1 (arquivo eletrônico).

${ }^{408}$ C. R. DinAmarco, O futuro do processo civil brasileiro in Fundamentos do processo civil moderno, tomo II, $4^{\text {a }}$ edição, São Paulo, Malheiros, 2001, pp. 729-730.

${ }^{409}$ O próprio C. R. DiNAMARCO explica que o processo civil de resultados corresponde a uma "adequação de seus instrumentos e suas técnicas aos objetivos a realizar, de modo que os efeitos substanciais externos da experiência processual sejam justos e efetivos (sem uma técnica adequada, a efetividade é impossível)." $O$ futuro cit., p. 757.

${ }^{410} \mathrm{Em}$ breve resumo, os escopos sociais do processo são (i) a pacificação dos conflitos com justiça ("a função jurisdicional e a legislação estão ligadas pela unidade do escopo fundamental de ambas: a paz social", mas "[i] sso não significa que a missão social pacificadora se dê por cumprida mediante o alcance de decisões, quaisquer que sejam e desconsiderado o teor das decisões tomadas. Entra aqui a relevância do valor justiça. Eliminar conflitos mediante critérios justos - eis o mais elevado escopo social das atividades jurídicas do Estado") e (ii) "conscientizar os membros desta para direitos e obrigações". Os escopos políticos do processo são três: (i) "afirmar a capacidade estatal de decidir imperativamente (poder)"; (ii) concretizar o culto ao valor liberdade; e (iii) "assegurar a participação dos cidadãos" "nos destinos da sociedade política". Por fim, o escopo jurídico da jurisdição corresponde à atuação da vontade concreta da lei. C. R. DINAMARCO, A instrumentalidade cit., pp. 188, 191, 198, 246 - grifos do original.

411 “compete ao processo a função primária de codificar a relação fundamental entre a iniciativa do indivíduo para a instauração do processo (princípios dispositivo e da demanda) e a possibilidade de se obter em juízo uma tutela jurisdicional adequada (adequação, ver-se-á depois, significa proporcionalidade entre efetividade e segurança). O importante é que a constitucionalização do direito ao processo e à jurisdição (a exemplo do artigo $5^{\circ}$, inciso XXXV, da Constituição brasileira), de envoltas com o direito fundamental de efetividade e a um processo justo (art. 5, incisos XXXVII, LIII, LIV, LV, LVI, LX e LXXVIII), determina também uma garantia 'de resultado', ressaltando o nexo teleológico fundamental entre 'o agir em juízo' e a 'tutela' jurisdicional do direito afirmado." Os direitos fundamentais à efetividade e à segurança em perspectiva dinâmica in C. A. SAlles (coord.), As grandes transformações do Processo Civil Brasileiro - Homenagem ao Professor Kazuo Watanabe, $1^{\text {a }}$ edição, São Paulo, Quartier Latin, 2009, pp. 38-39. 
ou chicana do adversário ${ }^{412}$. Contudo, não há espaço para formalismos inúteis ${ }^{413}$, que se busca afastar mediante as recentes reformas que alteraram disposições do Código de Processo Civil, notadamente em relação ao agravo de instrumento - tendência ${ }^{414}$ da qual não se afasta o projeto de novo Código de Processo Civil.

Com o mesmo intuito, busca-se a aceleração do procedimento para que o processo possa mais eficientemente atingir o fim a que é destinado, qual seja, a prolação de sentença a respeito do mérito da demanda. A título exemplificativo, pode-se citar nesse sentido a reforma que generalizou a possibilidade de concessão de tutelas antecipadas que, aliadas ao poder geral de cautela do juiz já anteriormente existente, se destinam claramente a minimizar os efeitos deletérios do transcurso do tempo sobre os direitos.

Na mesma linha de princípio segue o anteprojeto de novo Código de Processo Civil no que diz respeito à recorribilidade das decisões interlocutórias, pretendendo, com isso, simplificação e "obter-se o maior rendimento possível de cada processo" 415 .

\footnotetext{
412 "A forma em sentido amplo investe-se, assim, da tarefa de indicar as fronteiras para o começo e o fim do processo, circunscrever o material a ser formado, e estabelecer dentro de quais limites devem cooperar e agir as pessoas atuantes no processo para o seu desenvolvimento. $\mathrm{O}$ formalismo processual contém, portanto, a própria ideia do processo como organização da desordem, emprestando previsibilidade a todo o procedimento. Se o processo não obedecesse a uma ordem determinada, cada ato devendo ser praticado a seu devido tempo e lugar, fácil entender que o litígio desembocaria numa disputa desordenada, sem limites ou garantias para as partes, prevalecendo ou podendo prevalecer a arbitrariedade e a parcialidade do órgão judicial ou a chicana do adversário. Não se trata, porém, apenas de ordenar, mas também de disciplinar o poder do juiz e, nessa perspectiva, o formalismo processual atua como garantia de liberdade contra o arbítrio dos órgãos que exercem o poder do Estado." C. A. ALVARO DE OLIVEIRA, O formalismo-valorativo no confronto com o formalismo excessivo in F. DIDIER JR. (org.), Leituras complementares de Processo Civil, $8^{\mathrm{a}}$ edição revisada e ampliada, Salvador, Jus Podivm, 2010, pp. 149-150.

${ }^{413}$ É o que C. A. Alvaro DE Oliveira chama de formalismo excessivo, por ele definido da seguinte maneira: "Pode acontecer, contudo, e esse é o âmago do problema, que o poder organizador, ordenador e disciplinador do formalismo, em vez de concorrer para a realização do direito, aniquile o próprio direito ou determine um retardamento irrazoável da solução do litígio. Neste caso o formalismo se transforma no seu contrário: em vez de colaborar para a realização da justiça material, passa a ser o seu algoz, em vez de propiciar uma solução rápida e eficaz do processo, contribui para a extinção deste sem julgamento do mérito, obstando a que o instrumento atinja a sua finalidade essencial." O formalismo-valorativo cit., p. 159.
}

${ }^{414}$ É como se manifesta C. R. DinAMARCO: “Todo formalismo é, no processo, prejudicial à boa qualidade e à tempestividade da tutela jurisdicional, muito embora o processo seja em si mesmo formal e não possa dispensar os requisitos de forma racionalmente enunciados na lei e impostos pelo juiz. A tendência moderna é, por isso, francamente deformalizadora, i. é, existe um perene movimento dos sistemas processuais no sentido da dispensa de formas inúteis e busca de soluções mais ágeis e produtivas que as tradicionais, inclusive mediante apelo à tecnologia moderna." Aceleração dos procedimentos in Fundamentos do processo civil moderno, v. 2, 4a edição, São Paulo, Malheiros, 2001, p. 902.

415 Anteprojeto de Código de Processo Civil, Brasília, 2010, p. 28. 
Entretanto, é importante observar que esses objetivos encontram limites na observância do devido processo legal - garantia que contempla não só a razoável duração do processo, mas também a segurança do procedimento ${ }^{416}$. Dito de outra forma, conquanto se possa louvar a intenção de acelerar o procedimento para que venha a produzir a satisfação dos litigantes mais rapidamente, não se pode fazê-lo inconsequentemente, a ponto de não lhes conceder chances para se defenderem adequadamente, serem ouvidos em juízo, ou promoverem a revisão de determinada decisão jurisdicional que lhes tenha causado prejuízo.

\subsection{EFETIVIDADE DO PROCESSO}

Por "efetividade do processo" entende-se a aptidão do instrumento estatal de resolução de controvérsias para produzir na vida do jurisdicionado o efeito desejado pelo direito material, com segurança jurídica - ou seja, observando os princípios constitucionais que o norteiam -, em tempo razoável ${ }^{417}$.

Essa concepção segue a tendência ao instrumentalismo "substancial" do processo, identificada por KAZUO WATANABE, pela qual se procura fazer com que o processo seja tão aderente quanto possível à realidade do direito material, de modo a que possa servir como verdadeiro mecanismo de efetivação de direitos ${ }^{418}$.

\footnotetext{
${ }^{416}$ Substancialmente de acordo, J. R. CRUZ E TUCCI, para quem: "o processo judiciário, como instrumento de composição da lide (em âmbito extrapenal) ou resolutório de conflitos de interesses de alta relevância social (no campo penal), reclama, em homenagem a um elementar postulado de segurança jurídica, o respeito a uma série de garantias das partes (due process of law), cuja observância se faz incompatível com a precipitação". Garantia da prestação jurisdicional cit., p. 100.

417 "Processo efetivo é aquele que, observado o equilíbrio entre os valores segurança e celeridade, proporciona às partes o resultado desejado pelo direito material." Efetividade cit., p. 49 - grifos do original.

418 "Do conceptualismo e das abstrações dogmáticas que caracterizam a ciência processual e que lhe deram foros de ciência autônoma partem hoje os processualistas para a busca de instrumentalismo mais efetivo do processo, dentro de uma ótica mais abrangente e mais penetrante de toda a problemática sociojurídica. Não se trata de negar os resultados alcançados pela ciência processual até esta data. O que se pretende é fazer dessas conquistas doutrinárias e de seus melhores resultados um patamar para, com uma visão crítica e mais ampla da utilidade do processo, proceder ao melhor estudo dos institutos processuais - prestigiando ou adaptando ou reformulando os institutos tradicionais, ou concebendo institutos novos -, sempre com a preocupação de fazer com que o processo tenha plena e total aderência à realidade sociojurídica a que se destina, cumprindo sua primordial vocação, que é a de servir de instrumento à efetiva realização de direitos. É a tendência ao instrumentalismo que se denominaria substancial em contraposição ao instrumentalismo meramente nominal ou formal." Cognição cit., p. 20.
} 
Nota-se, então, que a ideia de efetividade contém um componente qualitativo no que diz respeito à decisão a ser proferida, não se limitando à celeridade ou à simplificação do procedimento. É como pensa ALVARO DE OLIVEIRA ${ }^{419}$, que adverte para os perigos que concepção simplista de efetividade - que privilegie a rápida solução do litígio, deixando de lado as outras garantias processuais - pode trazer para a justiça.

Da mesma forma, BARBOSA MOREIRA identifica três principais riscos aos quais está sujeito o movimento tendente à efetividade. Primeiramente, o de transformá-la num valor absoluto, passando por cima de outras garantias processuais igualmente importantes ${ }^{420}$. Em segundo lugar, no outro extremo, há o risco de se estender "além da medida razoável a duração do feito, pelo afã obsessivo de esgotar todas as possibilidade, mínimas que sejam, de apuração dos fatos" ${ }^{" 421}$. Por fim, há o risco de se promulgarem normas com deficiências técnicas e/ou de se aplicar deficientemente as normas promulgadas visando à efetividade, o que acarreta sobrecarga de trabalho para os órgãos judiciais, e o prolongamento excessivo dos processos ${ }^{422}$.

Essas ressalvas refletem basicamente o raciocínio de MARC GALANTER, que afirma, em relação ao direito estadunidense, que a definição do mecanismo de solução de controvérsias mais efetivo para o caso concreto se pode reduzir à análise de dois

\footnotetext{
${ }^{419}$ O processualista gaúcho identifica que, no Brasil, a questão da efetividade "também se agiganta - e parece ser esta uma causa nada desprezível - em razão das notórias deficiências da administração da Justiça, agoniada cada vez mais pela intensificação dos litígios, principalmente após o processo de redemocratização iniciado com a promulgação da Constituição de 1988." E destaca que a evolução das discussões a respeito chegou a tal ponto que "para alguns espíritos mais práticos tudo se resume na solução rápida, expedita, fulminante às vezes do próprio valor Justiça." "A questão que se coloca em semelhante contexto é se realmente se mostra desejável esse tipo de efetividade, indiferente à justiça, que conduz a uma negativa contraposição entre utilitarismo e justiça na medida em que a relativiza em função da performance, a transformar o juiz em burocrata, assimilando as funções executiva e judicial. A nosso entender, a efetividade só se revela virtuosa se não colocar no limbo outros valores importantes do processo, a começar pelo da justiça, mas não só por este." Efetividade e processo de conhecimento, obtido em www.rtoline.com.br, originalmente publicado em Revista de Processo, 96:1999, pp. 59 e seguintes, pp. 1, 1 e 2, respectivamente (arquivo eletrônico) - grifo do original.

420 “Cabe agora uma palavra de advertência par alguns riscos a que está sujeito o pensamento ordenado à efetividade do processo. Consiste o primeiro na tentação de arvorar a efetividade em valor absoluto: nada importaria senão tornar mais efetivo o processo, e nenhum preço seria excessivo para garantir o acesso a tal meta. É esquecer que no direito, como na vida, a suma sabedoria reside em conciliar, tanto quanto possível, solicitações contraditórias, inspiradas em interesses opostos e igualmente valiosos, de forma que a satisfação de um deles não implique o sacrifício total de outro." Efetividade do processo e técnica processual, obtido em www.rtonline.com.br, originalmente publicado em Revista de Processo, 77:1995, p. 168 e seguintes, p. 2 (arquivo eletrônico).

${ }^{421} \mathrm{O}$ processualista sintetiza, a respeito, que "Nem o valor celeridade deve primar, pura e simplesmente sobre o valor verdade, nem este sobrepor-se, em quaisquer circunstâncias, àquele". Efetividade cit., p. 2 (arquivo eletrônico).

${ }^{422}$ Cf. Efetividade cit., pp. 3-4 (arquivo eletrônico).
} 
parâmetros complementares: produção e qualidade. O primeiro corresponde à análise de fatores como custo e duração do processo, ou seja, à verificação de que mecanismo pode produzir "mais" com menor dispêndio de tempo e recursos ${ }^{423}$.

Porém, como já se acenou, o produto dessa observação isoladamente considerado será sempre incompleto, pois é também necessário investigar se é possível obter o resultado desejado pela utilização do mecanismo de solução de controvérsias mais célere e menos custoso. Essa segunda parte da formulação conduz a indagação a respeito de outros fatores associados à qualidade do mecanismo de solução de controvérsias, como a satisfação das partes, o estímulo a soluções de autocomposição, a redução de recursos, entre outros. Aliás, o próprio GALANTER explica que utiliza o termo "qualidade" (em inglês, "quality") para tratar aspectos valorativos, inclusive a justiça da decisão e outros que não admitem quantificação, que estão sempre associados à litigância ${ }^{424}$.

Entre nós, Carlos Alberto de Salles explica que os parâmetros de produção e qualidade se refletem em dois tipos de resultados que devem ser analisados em qualquer mecanismo processual. Assim, a noção de efetividade da tutela jurisdicional pressupõe análise externa do processo, e deve levar em consideração não só os objetivos desejados pelo direito material, como também o impacto da atividade jurisdicional sobre a situação de fato ${ }^{425}$.

423 "The many reasons for preferring one dispute mechanism over another can be reduced to two basic arguments. The first of these, which we might call the 'production' cluster, is that one or another mechanism will produce 'more' with less expenditure of resources. Thus we find arguments that a given device will increase the number and speed of resolutions and lower their cost." Introduction: compared to what? Assessing the quality of dispute resolution, disponível em www.marcgalanter.net, acesso em 31.12.2012

424 “These assertions about beneficial characteristics are 'quality' arguments. I use the term 'quality' as shorthand for the valued aspects of the process, including but not confined to justice, and including but not confined to those aspects that admit of quantification. The term was adopted to summarize and emphasize the wide range of valued characteristics, apart from cost, time and institutional convenience, that are implicated in disputing. Although quality arguments, explicit or tacit, are everywhere in discussions of dispute resolution, much less attention has been given to analyzing and appraising quality effects than to the more readily measurable production effects." Introduction cit., p. xii.

425 “A consideração da efetividade da tutela jurisdicional, como foi visto antes, impõe a formulação de um juízo sobre a adequação do procedimento e do provimento jurisdicional a uma determinada situação de fato, tomando em consideração não só seus objetivos imediatos (prestação de tutela à parte reclamante), mas também àqueles mediatos (relacionados com os valores e objetivos do ordenamento jurídico $=$, o que apenas será factível a partir de uma visão externa do processo, isto é, não restrita a seus próprios pressupostos." E prossegue: "Em rápida síntese, o conceito de efetividade implica uma consideração de meios e fins, podendo ter-se por efetivo aquele processo que atinge as finalidades a que se destina, considerando o conjunto de objetivos implícitos no direito material e a totalidade da repercussão da atividade jurisdicional sobre dada situação de fato". Processo civil de interesse público in C. A. SAlles (org.), Processo civil e interesse público - o processo como instrumento de defesa social, São Paulo, Associação Paulista do Ministério Público e Revista dos Tribunais, 2003, p. 51. 
Convém neste ponto destacar que essa efetividade não se confunde com a eficácia da sentença - segundo ensina LIEBMAN, ao decidir o caso concreto, a sentença, enquanto ato autoritativo emanado do Estado, sujeita a todos potencialmente, eis que não é dado a ninguém ignorá-la $\mathrm{a}^{426}$.

Como se pode verificar, a construção teórica da efetividade é relativamente simples, e a maior dificuldade que lhe é inerente concerne à sua aplicação prática, que depende de outros fatores, como por exemplo a situação pessoal dos litigantes. Isso porque parece claro que eventual provimento jurisdicional, ainda que justo, adequado e tempestivo, poderá vir a não produzir efeitos práticos em razão, por exemplo, da inexistência de patrimônio do devedor para efetuar o pagamento da condenação.

Essa constatação remete à circunstância de que a tutela jurisdicional pode, a depender da situação de direito material que se apresente, se consubstanciar em provimento declaratório, constitutivo ou condenatório. Nas duas primeiras situações, a prolação da sentença definitiva resolve a crise de certeza, única que envolve os litigantes. Porém, quando a controvérsia demanda a prolação de sentença condenatória (especialmente as que dizem respeito a obrigação de fazer ou de não fazer), a situação é bastante diversa, pois não há como se assegurar, pelo procedimento, a solução da crise de adimplemento.

Em outras palavras, alterações legislativas podem facilitar a entrega da prestação jurisdicional, mas não terão como garantir a satisfação do vencedor, posto que esta depende de outros componentes, no mais das vezes insuscetíveis de serem efetivamente garantidos por $1 \mathrm{ei}^{427}$. Essas considerações não se prestam a diminuir a

\footnotetext{
426 “A sentença, como ato autoritativo ditado por um órgão do Estado, reivindica naturalmente, perante todos, seu ofício de formular qual seja o comando concreto da lei ou, mais genericamente, a vontade do Estado, para um caso determinado. As partes, como sujeitos da relação a que se refere a decisão, são certamente as primeiras que sofrem a sua eficácia, mas não há motivo que exima os terceiros de sofrê-la igualmente. Uma vez que o juiz é o órgão ao qual atribui o Estado o mister de fazer atuar a vontade da lei no caso concreto, apresenta-se a sua sentença como eficaz exercício dessa função perante todo o ordenamento jurídico e todos os sujeitos que nele operam. Certamente, muitos terceiros permanecem indiferentes em face da sentença que decidiu somente a relação que em concreto foi submetida ao exame do juiz: mas todos, sem distinção, se encontram potencialmente em pé de igualdade de sujeição a respeito dos efeitos da sentença, efeitos que se produzirão efetivamente para todos aqueles cuja posição jurídica tenha qualquer conexão com o objeto do processo, porque para todos contém a decisão a atuação da vontade da lei no caso concreto." Eficácia e autoridade da sentença e outros escritos sobre a coisa julgada, com notas relativas ao direito brasileiro vigente por Ada Pellegrini Grinover, $2^{a}$ edição, Rio de Janeiro, Forense, 1981, p. 123.

427 "Nem sempre a tutela jurisdicional que as pessoas vêm buscar no processo consuma-se com a edição da sentença que julga as pretensões contrapostas das partes. Tutela é proteção e consiste na melhora que o litigante vencedor recebe na sua situação jurídica deduzida em juízo, de modo que, terminado o processo, ele
} 
importância do estudo da técnica processual ou da busca pela efetividade, mas apenas esclarecer que não se ignoram as limitações às quais está sujeito o estudo teórico da matéria ${ }^{428}$.

\subsection{Da RAzó́VEl duRAÇÃo do PROCESSO E DAS CAUSAS DA MOROSIDAde ATUALMENTE VERIFICADA}

Em complemento às afirmações precedentes, um importante aspecto da efetividade está relacionado ao tempo necessário para que o processo possa vir a produzir os resultados que dele se esperam na vida dos jurisdicionados. Mais do que apenas propiciar condições para que seja proferida decisão a respeito da controvérsia submetida à apreciação do Poder Judiciário, atualmente reconhece-se que a resposta jurisdicional deve ser ofertada tempestivamente ${ }^{429}$.

Esse anseio por processo justo com duração razoável não é novo, tendo sido invocado para justificar as mais diversas reformas processuais ocorridas na legislação pátria. Disso é exemplo a declaração de LUIS MACHADO GUIMARÃES contida em publicação anterior à promulgação do Código de Processo Civil de 1939, que dá conta de que "a distribuição de justiça no Brasil é feita com insuportável dispêndio de tempo e de dinheiro, e, o que é mais, insegura e precária em seus resultados" ${ }^{\prime 30}$.

se encontre, na sua vida comum em relação ao outro litigante e aos bens controvertidos, em situação melhor do que aquela em que se encontrava antes do processo. Há sentenças aptas a conceder por si próprias a tutela a quem tem razão, como a constitutiva e as declaratórias em geral (entre estas, as que julgam improcedente a demanda, tutelando o demandado), mas também existem as que deixam a situação ainda indefinida, sem eliminar de pronto a crise jurídica que envolve os litigantes. Tais são as sentenças condenatórias e, de modo mais agudo entre elas, as que condenam por obrigações de fazer ou de não-fazer." C. R. DINAMARCO, $O$ futuro cit., p. 755 - grifos do original.

${ }^{428}$ Nessa linha, J. R. S. BEDAQUE sintetizou com primazia o raciocínio: “o direito à sentença de mérito, embora insuficiente para garantir a efetividade, constitui etapa antecedente e essencial, na maioria dos casos, àquela em que são adotados os meios destinados à realização prática do direito. Justificável a preocupação com a segunda fase da efetivação da tutela, sem a qual o resultado do processo não passaria de peça de retórica. Mas continua válida a advertência feita logo no início: sem chegarmos ao final da primeira fase, com a obtenção da tutela cognitiva, não há como passarmos para a segunda”. Efetividade cit., p. 80.

${ }^{429}$ É o que afirma J. R. CRUZ E TUCCI: "Não basta, pois, que se assegure o acesso aos tribunais,k e conseqüentemente o direito ao processo. Delineia-se inafastável, também, a absoluta regularidade deste (direito no processo), com a verificação efetiva de todas as garantias resguardadas ao consumidor da justiça, em um breve prazo de tempo, isto é, dentro de um tempo justo, para a consecução do escopo que lhe é reservado." Tempo e processo - uma análise empírica das repercussões do tempo na fenomenologia processual (civil e penal), $1^{a}$ edição, São Paulo, Revista dos Tribunais, 1997, pp. 87-88 - grifos do original.

${ }^{430}$ O processo oral cit., p. 160. 
A declaração reflete o reconhecimento da importância que o já mencionado fator tempo projeta sobre o processo, podendo agravar situações de fato até o ponto de tornar irremediável o dano delas decorrente. A respeito, conhecida a afirmação de FRANCESCO CARNELUTTI, segundo a qual se poderia comparar o tempo a um inimigo contra o qual o juiz deve lutar a todo o tempo ${ }^{431}$.

Parte-se, pois, da ideia de que o desenho procedimental se consubstancia em modelo que, de acordo com a experiência, seria adequado para se atingir uma decisão mais justa e aderente à realidade - pela concessão às partes de oportunidades para apresentarem suas razões e se defenderem, pelo modo de colheita da prova, pela existência de preclusões que impulsionam adiante o procedimento e meios de impugnar as decisões interlocutórias no curso do procedimento -, mas com a observância dos princípios constitucionais de que já se tratou.

E, entre as garantias constitucionais que devem ser observadas, está a razoável duração do processo, prevista no art. 5, LXXVIII ("Todos são iguais perante a lei, sem distinção de qualquer natureza, garantindo-se aos brasileiros e aos estrangeiros residentes no País a inviolabilidade do direito à vida, à liberdade, à igualdade, à segurança e à propriedade, nos termos seguintes: (...) LXXVIII - a todos, no âmbito judicial e administrativo, são assegurados a razoável duração do processo e os meios que garantam a celeridade de sua tramitação"), inserido pela Emenda Constitucional no 45/2004.

Essa alteração seguiu tendência já observada na Convenção Americana sobre Direitos Humanos (Pacto de São José da Costa Rica - 1969 - introduzida no ordenamento brasileiro pelo Decreto $\left.n^{\circ} 678 / 1992\right)$ em cujo art. $8^{\circ}$ se lê: " 1 . Toda pessoa tem direito a ser ouvida, com as devidas garantias e dentro de um prazo razoável, por um juiz ou tribunal competente, independente e imparcial, estabelecido anteriormente por lei na apuração de qualquer acusação penal formulada contra ela, ou para que se determinem seus direitos ou obrigações de natureza civil, trabalhista, fiscal ou de qualquer outra natureza."

Evidentemente, não se ignora que, para se chegar ao fim de qualquer processo judicial, naturalmente, leva-se tempo - em razão do tipo de atividade

431 "Il valore, che il tempo ha nel processo, è immenso e, in gran parte, sconosciuto. Non sarebbe azzardato paragonare il tempo a un nemico, contro il quale il giudice lotta senza posa." Diritto e processo, $1^{\text {a }}$ edição, Nápoles, Morano, 1958, p. 354. 
desenvolvida, da respectiva complexidade e do necessário encadeamento de atos ${ }^{432}$. Tem-se observado empiricamente, contudo, que a duração do processo é fator de insatisfação entre os litigantes, de crise de confiança na Justiça ${ }^{433}$ e causa para as reformas que vêm sendo promulgadas, bem como para a reforma do Código de Processo Civil proposta.

Essas considerações revelam que o chamado "tempo oportuno", relativo ao encadeamento sucessivo de atos processuais praticados com observância dos respectivos prazos não se confunde com a lentidão responsável pelos anseios de mudança na estrutura processual $^{434}$.

É evidente a dificuldade de estabelecer parâmetros objetivos para a definição do conceito de duração "razoável" do processo - que deve necessariamente observar, sem prejuízo de eventuais outros fatores, (i) a expectativa das partes; (ii) as reais condições dos órgãos do Poder Judiciários e dos auxiliares da justiça; (iii) os prazos indispensáveis à preparação das manifestações a serem apresentadas; e (iv) o imprescindível tempo de maturação da causa para que o julgador tenha condições de tomar decisão com segurança.

Feita essa ressalva, resta claro que a valoração da duração dos processos se excessiva ou razoável - não pode ser realizada aprioristicamente, devendo ser avaliada a

\footnotetext{
${ }^{432}$ Esse, inclusive, é um dos obstáculos à efetividade processual identificados por A. PROTO PISANI relativamente ao processo de conhecimento: "Un processo di tale specie, in quanto diretto ad assicurare in modo completo la garanzia del contraddittorio, è sempre necessariamente uno strumento sofisticato che, Anche se disciplinato da forme accelerate quale ad es. quelle del rito speciale del lavoro, ha una sua fisiologica durata." E conclui: "Di qui l'inevitabile conseguenza che durante il tempo necessario per ottenere una sentenza esecutiva l'attore possa subire un pregiudizio irreparabile o comunque grave: danno che può consistere $\mathrm{o}$ 'nel sopraggiungere di fatti tali da porre in pericolo le concrete possibilità di attuazione della sentenza sul merito della controversia', o anche nel solo permanere del diritto in stato di insoddisfazione per tutto il tempo necessario ad ottenere una sentenza esecutiva nel corso del processo a cognizione piena; è il cosiddetto periculum in mora o, per usare la efficace terminologia di E. Finzi ripresa e diffusa da Calamandrei, il danno marginale che la durata del processo causa o concorre a causare." Lezioni cit., p. 651 grifos do original.

433 “É bem de ver que o fator tempo, que permeia a noção de processo, constitui, desde há muito, o principal motivo de crise da justiça, uma vez que a excessiva dilação temporal das controvérsias vulnera ex radice, o direito à tutela jurisdicional, acabando por ocasionar uma série de gravíssimos inconvenientes para as partes e para os membros da comunhão social. Despiciendo salientar que justiça tardia corresponde a verdadeira denegação de justiça...” J. R. CRUZ E TUCCI, Garantia da prestação jurisdicional cit., p. 100.

${ }^{434}$ Essa conclusão foi bem sintetizada por J. R. CRUZ E TUCCI, para quem "na realidade, a performance da administração da justiça encontra-se muito aquém de atender às expectativas e aos anseios da sociedade." Tempo e processo cit., p. 16 - grifo do original.
} 
partir de critérios como a complexidade da matéria envolvida e o comportamento das partes e do juiz ${ }^{435}$.

Mais do que isso, é possível afirmar que o processo jamais será apto a atender plenamente a expectativa da parte, que desejaria ter seu problema resolvido na mesma data em que aciona o Poder Judiciário - o que, pelas razões já explicadas, não só é inviável do ponto de vista fático, como também indesejável do ponto de vista teórico ${ }^{436}$.

Seja como for, é importante conhecer as causas da morosidade da justiça para que se possa compreender, num primeiro momento, se as suas soluções são suscetíveis de serem atingidas por meio de alteração legislativa e, a seguir, se a modificação contida nos projetos de novo Código de Processo Civil se prestariam a esse fim.

JosÉ RogÉRIO CRUZ E TUCCI afirma que se podem dividir as causas da lentidão processual em três grandes grupos: (i) fatores institucionais; (ii) fatores de ordem técnica e subjetiva; e (iii) fatores derivados da insuficiência material ${ }^{437}$.

Explica o processualista, relativamente aos aspectos institucionais, que a "eficiente administração da justiça não é meta digna de ser elevada ao vértice da escala das prioridades almejadas pelos Poderes Executivo e Legislativo" ${ }^{438}$. Em complemento, segundo ele, quando o assunto é debatido nessas esferas, a discussão se concentra em questões de cunho técnico, ignorando-se os fatores políticos, econômicos e culturais que na realidade constituem o cerne do problema da morosidade. Ainda em relação a este ponto, afirma ele que a promulgação de leis de caráter intervencionista e emergencial para a resolução de crises econômicas (no contexto do início da década de 1990) também

${ }^{435}$ Cf. J. R. CRUZ E TuCCI, Garantia da prestação jurisdicional cit., p. 104. O mesmo autor também ressalta que "o direito ao processo sem dilações indevidas, como corolário do devido processo legal, vem assegurado ao membro da comunhão social por norma de aplicação imediata." Garantia da prestação jurisdicional cit., p. 107 - grifo do original.

436 “A necessidade de simplificar os atos e o procedimento como um todo esbarra em óbices que são legítimos em si mesmos, representados pelos valores inerentes ao due process of law, mas perdem legitimidade na medida das distorções a que pode dar lugar sua leitura tradicionalista e despreocupada da efetividade do acesso à justiça." C. R. DinAMARCO, O futuro cit., p. 758.

${ }^{437}$ Cf. Tempo e processo cit., p. 99.

${ }^{438}$ Cf. Tempo e processo cit., p. 100. 
contribui para o aumento descontrolado de demandas entre particulares, entre si e contra o Estado $^{439}$.

Quanto aos fatores de ordem técnica e subjetiva, CRUZ E TUCCI salienta que o sistema processual tal como posto, em que se permite a ampla recorribilidade das decisões proferidas em primeiro grau de jurisdição, reduz significativamente a importância de postulados como a imediatidade, a identidade física do juiz e a concentração, embora se tenha, em tese, acolhido a regra da oralidade. Essa circunstância não só desprestigia as decisões proferidas pelo juízo monocrático, como também aumenta significativamente o tempo necessário para que o vencedor possa obter a satisfação do seu crédito - em razão, especialmente, da regra do efeito suspensivo do recurso de apelação por força de lei. Ainda, aponta ele que o excesso de trabalho impede que os juízes possam se aperfeiçoar culturamente da maneira adequada. Por fim, destaca também a "displicência quanto ao cumprimento dos prazos que têm como destinatários os juízes e auxiliares da justiça, e não aqueles estabelecidos para as partes - únicas obrigadas, efetivamente, a tê-los na devida conta, em prol da integral preservação dos respectivos direitos" ${ }^{440}$.

Substancialmente de acordo está BARBOSA MOREIRA no que diz respeito à deficiência técnica de certos juízes como fator que prejudica a efetividade processual. Para ele, se os magistrados manejassem adequadamente os mecanismos de filtro de ações viáveis previstos no Código de Processo Civil, muitas demandas não sobreviveriam à decisão inicial, e deixariam de ocupar o já assoberbado Poder Judiciário ${ }^{441}$.

\footnotetext{
${ }^{439}$ Cf. Tempo e processo cit., pp. 100-101.

${ }^{440}$ Cf. Tempo e processo cit., pp. 102-103.

${ }^{441}$ Para o professor carioca, "deficiências técnicas na aplicação da norma são fontes de numerosas desgraças. Para começar, dão ensejo à inútil sobrevivência de boa quantidade de processos que decerto não contribuiriam como contribuem para obstruir os canais judiciais se os juízes deles incumbidos manejassem com maior destreza os instrumentos que lhes oferecem os dispositivos do Código de Processo Civil concernentes ao indeferimento da petição inicial e à extinção do feito qual modalidade do julgamento conforme o estado do processo (arts. 295 e 329, respectivamente). Isso pressuporia, entre outras coisas, é óbvio, a posse de noções claras e seguras acerca de temas como a legitimidade para a causa, a impossibilidade jurídica do pedido, a litispendência e a coisa julgada, em que a dimensão técnica indiscutivelmente avulta. O emprego de melhor técnica reteria muitas iniciais no filtro do despacho liminar, e poria termo à marcha de muitos pleitos sem necessidade de audiência de instrução e julgamento num e outro caso, com cristalino lucro do ponto de vista da efetividade. Esta, vale insistir, sofre danos múltiplos, toda vez que a vida de um processo se estende mais do que o necessário: a lamentar não há só o gasto supérfluo de tempo e energias que a procrastinação do desfecho, já por si, representa, mas igualmente as repercussões desfavoráveis sobre a restante atividade do órgão judicial: onerado com essa carga podre, quiçá não tenha o juiz condições de dirigir com mão mais firme e operosa algum outro feito em que, por exemplo, seria oportuna a iniciativa probatória oficial, para melhor esclarecimento dos fatos relevantes." Efetividade do processo cit., p. 4 (arquivo eletrônico).
} 
Humberto THEOdORO JR. também se manifestou em sentido convergente, tendo afirmado que o desmazelo dos servidores do Poder Judiciário em relação aos prazos impróprios que lhe são fixados, contribui para a existência de "etapas mortas" no curso do processo, em que somente se aguarda a tomada de providências, sem que nada de fato ocorra $^{442}$, o que acarreta na lentidão conhecida.

Finalmente, a última ordem de fatores que contribuem para a morosidade do processo está relacionada à insuficiência material, ou, nos dizeres de CRUZ E TUCCI, à "existência de um inequívoco descompasso entre a legislação codificada e a realidade do serviço judiciário" ${ }^{" 43}$. Essa falta de estrutura material acarreta situações como a demora de meses para a realização de juízo de admissibilidade de recurso especial ou extraordinário pelo tribunal a quo, bem como se reflete nas precárias instalações em que funcionam órgãos do Poder Judiciário em diversas Comarcas do país ou na falta de informatização de diversos tribunais ${ }^{444}$.

Dentro desse aspecto, também é pertinente a observação de TERESA WAMBIER, que aponta o descompasso entre o aumento da litigiosidade associado ao vertiginoso crescimento populacional e conscientização das pessoas sobre seus direitos, de um lado, e a ausência de providências para o correspondente aparelhamento adequado do Poder Judiciário ${ }^{445}$.

\footnotetext{
${ }^{442}$ Afirma o processualista mineiro que "[o] Poder Judiciário é lamentável reconhecê-lo, é o mais burocratizado dos Poderes estatais, é o mais ineficiente na produção de efeitos práticos, é o mais refratário à modernização, é o mais ritualista; dá sua impotência pra superar a morosidade de seus serviços e o esclerosamento de suas rotinas operacionais." E prossegue: "[o] que retarda intoleravelmente a solução dos processos são as etapas mortas, isto é, o tempo consumido pelos agendes do Judiciário para revolver a praticar os atos que lhes competem. O processo demora é pela inércia e não pela exigência legal de longas diligências." Celeridade e efetividade da prestação jurisdicional. Insuficiência da reforma das leis processuais, obtido em www.rtonline.com.br, originalmente publicado em Revista de Processo, 125:2005, p. 125 e seguintes, pp. 6 e 7, respectivamente (arquivo eletrônico) - grifo do original.

${ }^{443}$ Tempo e processo cit., p. 105.

${ }^{444}$ Cf. Tempo e processo cit., pp. 105-110.

445 “A litigiosidade aumentou proporcionalmente ao crescimento vegetativo (nos últimos 35 anos a população brasileira dobrou) e ao incremento da informação a respeito dos direitos. Juizados Especiais Cíveis, Juizados Especiais Federais, Código de Defesa do Consumidor, ações coletivas, dentre outras tantas conquistas decorrentes da regulamentação de dispositivos constitucionais, certamente fizeram com que legiões de excluídos do serviço judiciário a ele tivessem acesso. No entanto, nada se fez, expressivamente, para que a estrutura do Poder Judiciário acompanhasse esse crescimento e fosse aparelhada para atender à nova ordem de demandas por justiça." O novo recurso de agravo, na perspectiva do amplo acesso à justiça, garantido pela Constituição Federal in L. FuX, N. Nery JR., T. A. A. WAMBIER (coords.), Processo e Constituição Estudos em homenagem ao Professor José Carlos Barbosa Moreira, São Paulo, Revista dos Tribunais, 2006, p. 1080 .
} 
Para concluir o raciocínio, interessante observar, que, para CRUZ E TUCCI, a atual legislação processual não é uma das causas da morosidade mencionada. Pelo contrário: embora possa evidentemente ser alvo de críticas, em sua opinião o Código de Processo Civil de 1973 é lei cientificamente bem estruturada ${ }^{446}$. Assim, evidente que as soluções para os problemas apontados deverão ser buscadas fora do âmbito da reforma legislativa.

Da mesma forma, pensa o já mencionado HuMBERTO THEOdORO JÚNIOR, para quem é necessária a criação de órgãos de planejamento e desenvolvimento de serviços forenses, bem como estudo e levantamento estatístico que permitam a precisa identificação dos momentos de estrangulamento dos processos de modo a que se possa eficazmente combatê-los ${ }^{447}$.

No mesmo sentido, vide ainda o pensamento de Jỗo BATISTA LOPES ${ }^{448}$, Carlos Alberto Alvaro de Oliveira ${ }^{449}$ e Sidnei Amendoeira JR. ${ }^{450}$. Diverge

\footnotetext{
446 “Afastem-se desde logo as críticas dirigidas à legislação processual, especialmente a de natureza civil. Promulgado há mais de duas décadas, e em vigor desde $1^{\circ}$ de janeiro de 1974 , o nosso atual Código de Processo Civil representa, inegavelmente, o ponto culminante da evolução científica do Direito Processual Civil em nosso país." E continua: "[a] despeito do individualismo que plasma a integralidade de seu texto, a exemplo, aliás, dos diplomas que lhe serviram de fonte de inspiração, e não obstante a existência de aspectos criticáveis concernentes à falta de rigor terminológico e, de certo modo, sistemático, a verdade é que, paradoxalmente, muitas das novidades que somente em época bem mais recente foram adotadas, $v . g$., pelo processo civil italiano, já haviam sido consagradas em nosso Código de Processo Civil, evidenciando a conspicuidade científica do estatuto brasileiro." Tempo e processo cit., p. 99.
}

447 “É, portanto, preciso conscientizar-se de que o aprimoramento da prestação jurisdicional não acontecerá somente em virtude de modificações procedimentais, nem tampouco do simples crescimento numérico dos juízes disponíveis. (...) É lastimável, mas não se pode deixar de reconhecer o regime caótico em que os órgãos encarregados da prestação jurisdicional no Brasil trabalham tanto do ponto de vista organizacional, como principalmente em torno da busca de solução para sua crônica inaptidão para enfrentar o problema do acúmulo de processos e da intolerável demora na prestação jurisdicional. Não há o mínimo de racionalidade administrativa, já que inexistem órgãos de planejamento e desenvolvimento dos serviços forenses, e nem mesmo estatística útil se organiza para verificar onde e porque se entrava a marcha dos processos." Celeridade cit., pp. 5-6 (arquivo eletrônico).

${ }^{448}$ Cf. Efetividade do processo e reforma do Código de Processo Civil: como explicar o paradoxo processo moderno - Justiça morosa?, Revista de Processo, 105:2002, p. 128.

${ }^{449}$ Cf. Os direitos cit., p. 40.

450 “(...) mais do que sucessivas alterações legislativas, o problema da recorribilidade das interlocutórias e, por consequência, do recurso de agravo (como no mais de todo o nosso sistema processual), é muito mais de carência de uma estrutura judiciária apta a conseguir enfrentar a demanda existente do qualquer (sic) outra coisa. E nisso, em nosso sentir, andou mal o legislador brasileiro, ao ceder às pressões oriundas de setores do Poder Judiciário e de parte da doutrina e insistir em reformas legislativas sucessivas que dificilmente trarão maiores resultados práticos, já que o problema não é legal, mas estrutural, e demanda uma ampla reforma do Poder Judiciário em si mesmo, além de uma ampla reforma no setor público brasileiro de modo geral." Mais uma vez o agravo... in C. A. CARMONA (coord.), Reflexões sobre a reforma do Código de Processo Civil Estudos em homenagem a Ada Pellegrini Grinover, Cândido R. Dinamarco e Kazuo Watanabe, $1^{\mathrm{a}}$ edição, São Paulo, Atlas, 2007, p. 356. 
parcialmente OvÍDIO BAPTISTA DA SILVA, para quem o sistema processual funcionaria adequadamente dentro das premissas para as quais foi concebido, pelas quais, segundo ele, se teria renunciado à efetividade, dando-se primazia à segurança ${ }^{451}$.

O que se procurou demonstrar é que o problema de performance atualmente verificado é complexo e possui mais de uma causa. Seus contornos foram bem delineados por BARBosa MoReIRA, a partir de perspectiva negativa, ou seja, buscando afastar falsas proposições comuns à temática.

Ensina o professor fluminense que (i) o problema da excessiva duração dos processos é multissecular, mas que hoje em dia assume proporções maiores, ou é tido como mais grave em razão de traços psicológicos do homem de hoje, impaciente com a demora; (ii) trata-se de mazela que atinge os mais diversos países, não sendo exclusiva do aparelho brasileiro; (iii) em geral, pelo menos uma das partes do processo não está interessada no seu rápido desfecho, e tende a se valer dos meios à sua disposição para retardá-lo; (iv) a solução para reduzir a duração dos processos não reside exclusiva nem principalmente na mudança da legislação; e (v) a utilização de meios alternativos de solução de conflitos não é apta a desafogar substancialmente o Poder Judiciário de modo a aumentar-lhe a eficiência ${ }^{452}$.

Parece então lógico que mencionado problema somente poderia ser resolvido em definitivo se fosse enfrentado em todas as suas frentes - o que por óbvio demandaria soluções outras que não apenas alteração legislativa.

\footnotetext{
451 “Ao contrário da opinião dominante, porém, penso que o Poder Judiciário funciona bem, tendo em vista o condicionalismo teórico e político dentro do qual ele sobrevive. (...) Ele funciona segundo os princípios e pressupostos imaginados por aqueles que o conceberam. Um ponto que não preocupa aqueles que se angustia (sic) com os atuais problemas da administração da justiça é saber se a celeridade processual fora, realmente, concebida como um objetivo desejado pelo sistema. Ou seja, inda não se demonstrou que nosso sistema processual fora programado para andar rápido. Ao contrário, ao priorizar o valor segurança, inspirada em juízos de certeza, como uma imposição das filosofias liberais do Iluminismo, o sistema renunciou à busca de efetividade - que nossas circunstâncias identificam com celeridade -, capaz de atender a solicitação de nossa apressada civilização pós-moderna. O Poder Judiciário funciona satisfatoriamente bem em nosso país. Os problemas da Justiça são estruturais. Não funcionais. Ele atende rigorosamente bem ao modelo que o concebeu." Da função à estrutura in C. A. SALLES (coord.), As grandes transformações do Processo Civil Brasileiro - Homenagem ao Professor Kazuo Watanabe, $1^{\text {a }}$ edição, São Paulo, Quartier Latin, 2009, p. 96.

${ }^{452}$ Cf. O problema da duração dos processos: premissas para uma discussão séria in Temas de direito processual - $9^{a}$ série, $1^{a}$ edição, São Paulo, Saraiva, 2007, pp. 369, 370, 372, 373 e 375, respectivamente (a cada página corresponde um "equívoco" apontado por J. C. BARBOSA MOREIRA). Essas ideias repetem substancialmente o conteúdo de outro artigo de sua autoria, ao qual se remete o leitor, intitulado $O$ futuro da justiça: alguns mitos in Temas de direito processual - $8^{a}$ série, $1^{\mathrm{a}}$ edição, São Paulo, Saraiva, 2004, pp. 1-14.
} 
Evidentemente, não se está pretendendo sustentar que o Código atual seria isento de falhas. E, se o sistema não é perfeito, também não se nega que mudanças que o aprimorem são bem-vindas. O que se busca é a delimitação, tão precisa quanto possível, da expectativa que se pode ter em relação ao impacto de qualquer alteração legislativa sobre o problema global, para evitar a ingenuidade de crer seja essa solução completa, evitando-se frustração futura ${ }^{453}$. Esse será o tema dos próximos tópicos.

\subsection{ADEQUAÇÃO DO PROCESSO COMO FORMA DE PROMOVER A EFETIVIDADE}

Sem prejuízo das considerações já deduzidas, tem-se que as propostas de reforma se fundam na premissa de que a legislação atual, embora tecnicamente coerente, porque cientificamente pensada e cunhada, seria de alguma maneira inadequada no que diz respeito à sua aplicabilidade. Por isso, a tentativa de aprimoramento visando à maior aderência entre a lei processual e a sua aplicação prática. Nesse sentido se manifestou SÁlvio de FigueIREDo TEIXEIRA, um dos juristas mais atuantes nas reformas que passaram a ser implementadas no processo civil a partir da década de $1990^{454}$.

Com efeito, uma das maneiras pelas quais em teoria se pode buscar a efetividade da tutela jurisdicional é a alteração legislativa para modificar a técnica processual $^{455}$.

\footnotetext{
${ }^{453}$ Esse é o pensamento de J. C. BARBOSA MoREIRA, que afirma que ao processualista cumpre "tomar consciência clara das limitações a que está sujeito, para não incidir na ingenuidade de pensar que the é possível desatar todos os nós com os meros instrumentos próprios do seu ofício". Notas sobre o problema da "efetividade" do processo in Temas de direito processual - $3^{a}$ série, $1^{a}$ edição, São Paulo, Saraiva, 1984, p. 30.

${ }^{454}$ É o que explica SÁlvio DE FIgUeiredo TeIXeIRA: “o nosso Código, com algumas ressalvas, é induvidosamente bem estruturado em suas linhas arquitetônicas, elaborado que foi com técnica e cientificidade. $\mathrm{O}$ que nele se apresenta deficiente é exatamente a sua disciplina divorciada da realidade, a refletir o hermetismo com que foi elaborado, sem a participação dos diversos segmentos da comunidade jurídica nacional. Daí as notórias deficiências de sua aplicação na prática forense do dia-a-dia, de que é exemplo o seu modelo de procedimento sumaríssimo." A efetividade do processo e a reforma processual in J. R. CRuZ E Tucci (coord.), Processo civil: evolução - 20 anos de vigência, $1^{\text {a }}$ edição, São Paulo, Saraiva, 1995, pp. 233-234.

455 "Entre as várias alternativas existentes com vistas à redução da morosidade, propõe-se o reexame da técnica processual, que deve ser tratada com plena consciência de seus objetivos. É preciso compatibilizá-la com a natureza instrumental do processo. O caminho mais seguro é a simplificação do procedimento, com a flexibilização das exigências formais, a fim de que possam ser adequadas aos fins pretendidos ou até ignoradas, quando não se revelarem imprescindíveis em determinadas situações.” J. R. S. BEDAQUE, Efetividade cit., p. 51.
} 
Trata-se, novamente, do reconhecimento do caráter instrumental do processo, e via de consequência da técnica processual ${ }^{456}$. Prega-se, nesse contexto, a simplificação do procedimento, eliminando formalismos inúteis e promovendo o maior aproveitamento possível dos atos processuais ${ }^{457}$.

Em conhecido artigo, BARBOSA MoreIRA estabeleceu valiosas diretrizes que comporiam o que chamou de "programa básico" da efetividade, que deveria conter (i) instrumentos adequados a todos os direitos contemplados pelo direito material, que sejam utilizáveis na prática; e (ii) mecanismos para que a que a decisão seja, tanto quanto possível, baseada numa reconstituição fiel dos fatos. Esse processo deverá, ainda, evidentemente na medida do possível, assegurar ao vencedor o resultado prático desejado pelo direito material, com o menor dispêndio de tempo e recursos públicos ${ }^{458}$.

Essas orientações revelam a existência de dois métodos distintos para a busca da efetividade, a partir de perspectivas de direito material e de direito processual, respectivamente. A primeira busca a correlação entre a pretensão de direito material e as correspondentes ação de direito processual e pretensão à tutela jurídica processual ${ }^{459}$.

\footnotetext{
456 "Efetividade do processo é expressão que, superando as objeções de alguns, se tem largamente difundido nos últimos anos. Querer que o processo seja efetivo é querer que desempenhe com eficiência o papel que lhe compete na economia do ordenamento jurídico. Visto que esse papel é instrumental em relação ao direito substantivo, também se costuma falar da instrumentalidade do processo. Uma noção conecta-se com a outra e por assim dizer a implica. Qualquer instrumento será bom na medida em que sirva de modo prestimoso à consecução dos fins da obra a que se ordena; em outras palavras, na medida em que seja efetivo. Vale dizer: sreá efetivo o processo que constitua instrumento eficiente de realização do direito material." J. C. BARBOSA Moreira, Por um processo socialmente efetivo, Revista de Processo, 105:2002.

457 "De tudo que foi dito e analisado impõe-se afastar o formalismo oco e vazio, incapaz de servir às finalidades essenciais do processo - relativizada assim qualquer invalidade daí decorrente -, mormente quando atente contra os princípios e valores imperantes no ambiente processual, a exemplo da efetividade, da segurança, da boa-fé e lealdade e do princípio do processo justo.” C. A. Alvaro DE OliveIRA, $O$ formalismo-valorativo cit., p. 164.
}

458 “a) o processo deve dispor de instrumentos de tutela adequados, na medida do possível, a todos os direitos (e outras posições jurídicas de vantagem) contemplados no ordenamento, quer resultem de expressa previsão normativa, quer se possam inferir do sistema; b) esses instrumentos devem ser praticamente utilizáveis, ao menos em princípio, sejam quais forem os supostos titulares dos direitos (e das outras posições jurídicas de vantagem) de cuja preservação ou reintegração se cogita, inclusive quando indeterminado ou indeterminável o círculo dos eventuais sujeitos; c) impende assegurar condições propícias à exata e completa reconstituição dos fatos relevantes a fim de que o convencimento do julgador corresponda, tanto quanto puder, à realidade; d) em toda a extensão da possibilidade prática, o resultado do processo há de ser tal que assegure à parte vitoriosa o gozo pleno da específica utilidade a que faz jus segundo o ordenamento; e) cumpre que se possa atingir semelhante resultado com o mínimo dispêndio de tempo e energia." Notas sobre o problema da cit., pp. 27-28.

${ }^{459}$ Cf. K. WATANABE: “Os processualistas dessa tendência procuram desenvolver o estudo do direito subjetivo, da pretensão de direito material, conduzindo à conclusão de que, no plano processual, a cada ação de direito material corresponde, de ordinário, uma 'ação' de direito processual e uma pretensão processual. A parte teria pretensão (e também ação) à declaração, ou à condenação, ou à constituição, ou à execução, ou 
Já o enfoque de direito processual pretende, pelo estudo e aprimoramento dos institutos processuais, compatibilizar a técnica processual com a natureza instrumental do processo, de modo a propiciar tutela mais adequada dos direitos.

Nessa segunda perspectiva se insere o movimento reformista que culminou com a alteração de diversos dispositivos do Código de Processo Civil atualmente vigente (Lei n ${ }^{0} 5.869 / 1973$ ) a partir do início da década de 1990 e a proposta de modificação legislativa para a "simplificação" da técnica processual e maior aproveitamento dos atos pela alteração do regime de recorribilidade das decisões interlocutórias ${ }^{460}$.

\subsubsection{SEGUE: ESPECIFICAMENTE EM RELAÇÃO À RECORRIBILIDADE DAS DECISÕES INTERLOCUTÓRIAS}

No que diz respeito ao sistema de recorribilidade das decisões interlocutórias propriamente, dois principais caminhos se mostram no âmbito da alteração legislativa com o fim de conferir mais efetividade ao processo: a eliminação (ainda que parcial) do agravo, vedando à parte a rediscussão da matéria que tenha sido objeto de decisão interlocutória, ou a alteração do regime de preclusões, de modo que a parte possa impugnar a decisão interlocutória juntamente com a sentença em momento posterior.

A solução da eliminação pura e simples do agravo apresenta dois inconvenientes principais: de um lado, confere excessiva rigidez ao procedimento, na medida em que reduz significativamente a possibilidade de a parte influir nos rumos do processo em primeiro grau, o que inclusive impacta na satisfação da parte decorrente da legitimação pelo procedimento. Para ilustrar, menciona-se o exemplo de demanda em que a parte pleiteia a produção de prova pericial, indeferida pelo juiz. No sistema atual, a parte pode interpor agravo de instrumento que, se provido, determinará a realização da prova requerida. Dessa forma, parece lógico que a parte influiu na tomada da decisão, à medida em que, ao proferir sentença, o juiz deverá levar em consideração o laudo pericial produzido, a despeito de inicialmente ter entendido que a prova não seria necessária.

ainda ao mandamento (para aqueles os que sustentam, assim como nós, a admissibilidade da ação e sentença mandamental) já no plano do direito material, e sua processualização se dá através da demanda, que constitui exigência da promessa estatal de tutela jurídica, nascendo a pretensão processual com o pedido (petitum)". Cognição cit., p. 21. Vide também C. NEVES, Estrutura cit., pp. 83-84.

${ }^{460}$ Cf. J. R. S. BeDAQUE, Efetividade cit., p. 51. 
De outro lado, a eliminação total do agravo não é coerente com sistema que permite a eficácia imediata de decisões antecipatórias de tutela com caráter satisfativo, desde que não haja perigo de irreversibilidade do provimento (art. 273, §1 $1^{\circ}, \mathrm{CPC}$ ). Eventual supressão do agravo nesse contexto não eliminaria a necessidade de impugnação imediata da decisão, mas apenas esse meio para fazê-lo, abrindo caminho para sucêdaneos recursais.

A alteração do regime de preclusões - segundo modo aventado de implementação da mudança no sistema de recorribilidade de interlocutórias - possui dupla faceta, como já se explicou, uma vez que a preclusão é fenômeno que recai não só sobre a atividade das partes, mas também sobre a do juiz. Daí que a menor preclusividade para as partes estaria ordinariamente associada à menor preclusividade para o juiz, o que implicaria na possibilidade de o julgador em primeiro grau rever, de ofício ou a requerimento das partes, suas próprias decisões.

Essa possibilidade chegou a ser sugerida por TOMÁs PARÁ FILHO, pouco após a promulgação do Código de Processo Civil de 1973, como forma de minimizar o problema da sobrecarga dos tribunais, já então assoberbados. Para ele, à luz do princípio da oralidade, as decisões interlocutórias deveriam ser passíveis de revisão pelo próprio juiz prolator, afastando-se sua precludibilidade ${ }^{461}$.

Essa saída em tese eliminaria a necessidade de recurso, mas traria consigo o inconveniente da proliferação de pedidos de reconsideração, que também poderiam atrasar o procedimento em primeiro grau. Além disso, implicaria mudança na estrutura global do processo, uma vez que a preclusividade - com a adoção do princípio da eventualidade e a divisão do procedimento em fases relativamente estanques - é um dos seus traços característicos. Justamente por isso, HEITOR SICA se mostra pessimista sobre solução desse tipo que, segundo ele, representaria "não só uma drástica quebra de paradigmas técnicodogmáticos, mas também com flagrante distanciamento da cultura do advogado brasileiro, que recorre de todas as interlocutórias, para evitar a preclusão"462.

\footnotetext{
461 "Se, portanto, ao invés de se permitir o indiscriminado recurso de agravo de instrumento contra 'todas as decisões proferidas no processo', não apeláveis, se houvesse estabelecido, coibindo a precludibilidade das ordinatórias, a sua revisão pelo próprio juiz, independentemente de recurso, estar-se-ia cortando pela raiz a possibilidade enorme número de impugnações de ordinatórias, desde que não acarretem prejuízo atual." $A$ recorribilidade cit., p. 4 (arquivo eletrônico).

${ }^{462}$ Recorribilidade cit., p. 190.
} 


\subsection{Conclusão Parcial}

As considerações até aqui deduzidas revelam que a intenção de repensar o método atual de resolução de controvérsias para que possa produzir os resultados que dele se esperam pode ser, a princípio, positiva. E, na realidade, sequer poderia ser diferente, pois, como afirmou BARBosa MoreIRA, "o processualista, enquanto processualista, lida com a lei - quer em perspectiva de lege lata, quer de lege ferenda"463.

Porém, não se pode olvidar a ulterior observação do mesmo professor, no sentido que, ainda que se foco de trabalho seja a lei, isso não autoriza o processualista a fechar os olhos para a o modo de solucionar os problemas, que por vezes se afasta da mera alteração legislativa ${ }^{464}$.

Nesse contexto, importante não perder de vista que tal desiderato sempre encontra (e encontrará) obstáculo em razões que escapam ao alcance de qualquer alteração legislativa, como bem apontado por ROGÉRIO LAURIA TUCCI, cujas observações realizadas em 1985 continuam atuais ${ }^{465}$.

Com efeito, embora não se trate propriamente de novidade ${ }^{466}$, permanece atual a percepção de que a promulgação de novo Código de Processo Civil não terá o

${ }^{463}$ Notas sobre o problema cit., pp. 29-30.

464 “(...) o processualista não está dispensado de dedicar atenção a um problema pela simples circunstância de que a respectiva solução depende também - ou mesmo principalmente - de fatores estranhos ao universo da sua disciplina, ou, quem sabe, em termos mais genéricos, ao mundo do direito". Notas sobre o problema cit., p. 30 .

465 “(...) como também se faz notório, o problema mais tormentoso da Justiça brasileira encontra-se, por certo, em sua deficiente estruturação, ganhando maior dimensão: a) a falta de autonomia financeira e política do Poder Judiciário, tanto no plano federal como no das unidades de nossa República Federativa; b) o parco número de juízes, recrutados, em sua quase-totalidade, sem a necessária experiência forense; c) a rapidez da progressão na carreira, em detrimência do indispensável e conveniente amadurecimento paulatino dos magistrados; d) em boa parte do País, os aviltados salários por estes percebidos, sobretudo comparativamente aos honorários conferidos aos patronos dos litigantes, por força do vigor do denominado princípio da sucumbência; e) a total inadequação, dado o seu obsoletismo, dos meios materiais utilizados, imprescindíveis a efetivação da ação judiciária; e, complementarmente, f) o reduzido número e a inabilitação profissional, em grande maioria, dos funcionários auxiliares dos juízos e tribunais.” Juizado cit., p. 4.

${ }^{466}$ Em artigo publicado em 1995, antes da promulgação da Lei $n^{\circ}$ 9.139/1995, que alterou a disciplina original do agravo no Código de Processo Civil de 1973, S. F. TEIXEIRA assim se manifestou: "não se pode deixar de assinalar que a efetividade da tutela jurisdicional, que tanto se persegue, não depende apenas de mudanças na legislação processual. Depende igualmente de uma série de outros fatores, dentre os quais tem relevo uma boa organização judiciária, sem os males crônicos do nosso modelo avoengo e coimbrão, onde notórias a precariedade de meios, a falta da métodos, a ausência de tecnologia avançada, a pouca ou nenhuma 
condão de resolver todos os problemas que atualmente projetam seus reflexos para o processo e os resultados que pode vir a gerar na vida dos jurisdicionados.

Algumas dessas vicissitudes $\quad-$ das quais se cita apenas exemplificativamente o excessivo número de processos (e, correlatamente, o insuficiente número de juízes) e a insubsistente informatização dos procedimentos - têm origem e, naturalmente, solução também fora do processo e das leis que o disciplinam ${ }^{467}$.

A reforçar essa conclusão, constata-se que não existe justificativa técnica para a modificação do sistema de impugnação de decisões interlocutórias no momento atual. Pelo contrário, o atual agravo é eficiente, talvez o mais eficiente que já tenhamos tido. Assim, embora não se ignore o perigo decorrente da generalização, é possível afirmar que as razões que embasam as mudanças propostas são, no mais das vezes, extraprocessuais, possuindo cunho político ou econômico.

Novamente, e correndo o risco da repetição, não se nega que eventual alteração legislativa para promover a aceleração ou a simplificação do procedimento sem descurar das garantias às partes pode ser positiva. $\mathrm{O}$ que se procurou demonstrar é que não é por si, contudo, suficiente para resolver todos os problemas atualmente enfrentados, eis que não ataca diretamente as suas causas ${ }^{468}$.

Dito de outra forma, ínsita à concepção de que se pode melhorar substancialmente o processo civil por alteração legislativa está logicamente a ideia de que as leis processuais seriam em alguma medida a causa do problema da morosidade e pouca efetividade do processo civil brasileiro, correspondendo a alteração do instrumento à respectiva solução.

criatividade, tudo isso em uma sociedade desafiadoramente de massa e cada dia mais exigente e sofisticada". A efetividade cit., p. 242.

${ }^{467}$ A esse respeito, K. WATANABE observou que "por mais perfeitas que sejam as leis materiais e processuais, será sempre falha a tutela jurisdicional dos direitos, se inexistirem juízes preparados para aplicálas e uma adequada infraestrutura material e pessoal para lhes dar o apoio necessário." Cognição cit., p. 28.

${ }^{468}$ Nesse sentido, novamente invoca-se a lição de J. C. BARBOSA MOREIRA: "Um olhar de frente à realidade desestimula qualquer ilusão 'piedosa' sobre a possibilidade de produzir modificações de substância pela utilização de expedientes hermenêuticos ou pela reformulação de textos legais. Isso não deve servir de pretexto, repita-se, a que nos desinteressemos de semelhantes questões e nos encerremos na famosa 'torre de marfim'. Não alimentar esperanças irrealísticas é uma coisa; outra, bem diferente, é querer descobrir na existência de limites à eficácia do nosso agir uma justificativa cômoda para a renúncia pura e simples à ação." Notas sobre o problema cit., p. 31. 
Ocorre que a construção, conquanto em tese dotada de sentido, não está apoiada em dados estatísticos em que se possa apoiar o raciocínio para fins de maior concretude $^{469}$. Daí não se poder confirmar com certeza a medida de seu acerto na prática, o que esvazia as possibilidades de avaliação dos resultados das reformas processuais já levadas a cabo e da necessidade das que estão sendo propostas.

Sem ignorar essa limitação, contra a percepção de que se poderia remediar o problema mencionado por meio de simples alteração legislativa se insurgiu BARBOSA MoreIRA em diversas oportunidades ${ }^{470}$. Substancialmente de acordo, ARAKEN DE ASSIS, para quem "pretender a erradicação do problema da demora por intermédio das reformas processuais consiste em eleger solução simplista e rumo equivocado" ${ }^{\natural 71}$.

Em tal contexto, considerada a possibilidade de dano irreparável ou de difícil reparação decorrente de decisão interlocutória, a existência do recurso de agravo não pode ser tida como fator de retardamento apto a autorizar a supressão do recurso. Deve-se ter em conta que o fato de o procedimento se desenvolver em dois graus de jurisdição, no caso, configura lentidão necessária para que a parte não seja injustamente prejudicada, ou ao menos para diminuir o risco de que isso aconteça ${ }^{472}$.

Para concluir parcialmente, invoca-se uma vez mais a lição de BARBOSA MOREIRA, que bem sintetiza a percepção: “[a] esta altura parece chegado, para o processualista, o momento de reconhecer que esbarra numa daquelas raias extremas da sua competência específica. E decerto não se proclamará novidade alguma se a isso se quiser

\footnotetext{
${ }^{469}$ Conquanto notória a importância de dados estatísticos a respeito das causas de duração excessiva dos processos, J. C. BARBOSA MOREIRA assim se manifestou sobre o tema: "[a]ntes de mais nada, cumpre salientar a absoluta irrelevância daquilo a que se pode chamar a 'exemplificação anedótica'. Quase sempre, quando se traz o assunto à baila, alguém supõe contribuir valiosamente para o debate citando determinado caso em que pessoa da família, ou do grupo de amigos, se viu envolvida em pleito de longa duração. (...) Não precisamos de exemplos acidentais; precisamos, sim, de dados estatísticos colhidos e tratados com boa técnica. A estatística, todos sabemos lida com grandes números". E prossegue, afirmando que elementos colhidos a partir de dados estatísticos "são imprescindíveis para a identificação dos fatores de retardamento e do peso de cada qual. Só assim se poderá traçar estratégia que evite o risco de investirmos quixotescamente contra moinhos de vento, deixando em paz e sossego os verdadeiros inimigos." O problema cit., pp. 367 e 369 , respectivamente.

${ }^{470}$ Destaca-se, por oportuna, sua manifestação em artigo no qual denunciou a "crença simplista de que, alterando a redação de um artigo ou introduzindo-lhe um novo parágrafo, se pode dar como solucionado um problema da vida jurídica. A norma, vale sublinhar, nem é impotente, nem onipotente". O futuro da justiça cit., p. 10 .

${ }^{471}$ Duração razoável do processo e reformas da lei processual civil in L. FUX, N. NERY JR., T. A. A. WAMBIER (coords.), Processo e Constituição - Estudos em homenagem ao Professor José Carlos Barbosa Moreira, $1^{\text {a }}$ edição, São Paulo, 2006, p. 197.

${ }^{472}$ Cf. E. Allorio, Sul doppio grado cit., p. 1788.
} 
acrescentar que o estudo do tema em nível mais profundo necessariamente desembocaria em ampla reflexão (incabível nesta sede) sobre o contexto político, econômico e social em que se insere a problemática da 'efetividade' do processo" ${ }^{273}$.

${ }^{473}$ Notas sobre o problema cit., p. 42. 


\section{A respeito da Proposta de Novo Código de Processo Civil}

\subsection{ANTEPRojeto Elaborado PELA Comissão de JURistas}

Em 30.9.2009, o ato n ${ }^{\mathrm{o}}$ 379/2009 do Presidente do Senado Federal instituiu Comissão de Juristas com a incumbência de redigir anteprojeto de novo Código de Processo Civil.

A comissão, composta por Luiz Fux (presidente), Teresa Arruda Alvim Wambier (Relatora), Adroaldo Furtado Fabrício, Humberto Theodoro Júnior, Paulo Cesar Pinheiro Carneiro, José Roberto dos Santos Bedaque, José Miguel Garcia Medina, Bruno Dantas, Jansen Fialho de Almeida, Benedito Cerezzo Pereira Filho, Marcus Vinicius Furtado Coelho e Elpídio Donizetti Nunes realizou audiências públicas para a discussão de propostas e apresentou, em junho/2010, anteprojeto composto por 970 artigos no total, prevendo mudanças no que diz respeito à recorribilidade das decisões interlocutórias.

As principais modificações sugeridas no tocante ao objeto do presente trabalho são, de um lado, a eliminação do agravo retido, alterando-se o momento da manifestação do inconformismo e, de outro, o elenco das hipóteses de cabimento de agravo de instrumento. Digna de nota ainda a possibilidade de sustentação oral no julgamento de agravo de instrumento tirado contra decisão interlocutória de mérito ${ }^{474}$.

De acordo com o art. 929 da redação original do anteprojeto, portanto, seriam impugnáveis por agravo de instrumento as decisões interlocutórias "I - que versarem sobre tutelas de urgência ou da evidência; II - que versarem sobre o mérito da causa: III - proferidas na fase de cumprimento de sentença ou no processo de execução; IV - em outros casos expressamente referidos neste Código ou na lei."

De maneira esparsa, previu-se no anteprojeto que seria cabível agravo de instrumento contra a decisão interlocutória que: (i) resolvesse incidente de desconsideração da personalidade jurídica (art. 65); (ii) apreciasse o requerimento de gratuidade da justiça (art. 85, $\S 2^{\circ}$ ); (iii) concedesse ou negasse tutela de urgência ou de evidência (art. 279,

${ }^{474}$ Trata-se de inovação: atualmente, não é permitida sustentação oral em julgamento de agravo de instrumento, ainda que verse sobre decisão de mérito. 
parágrafo único); (iv) deferisse ou negasse o pedido de assistência (art. 322, parágrafo único); (v) determinasse a apresentação (ou não) de documento ou coisa por terceiro (art. 382, parágrafo único); (vi) definisse o valor devido em procedimento de liquidação de sentença (art. 494, $\S 7^{\circ}$ ); (vii) apreciasse as pretensões dos credores a respeito do direito de preferência e da anterioridade da penhora na fase expropriatória do cumprimento de sentença (art. 833, parágrafo único); (viii) fossem proferidas em processos nos quais forem partes, de um lado, Estado estrangeiro ou organismo internacional e, do outro, Município ou pessoa residente ou domiciliada no País (art. 942, II, “b”).

Ainda, afirmou-se de maneira expressa que "[a]s questões resolvidas por outras decisões interlocutórias proferidas antes da sentença não ficam acobertadas pela preclusão, podendo ser impugnadas pela parte, em preliminar, nas razões ou contrarrazões de apelação".

De acordo com o anteprojeto apresentado pela Comissão de Juristas, houve duas justificativas gerais para as propostas mencionadas. Em primeiro lugar, procurou-se propiciar o máximo aproveitamento dos atos processuais, para que cada processo venha a ter o maior rendimento possível. Também se buscou conferir organicidade às disposições, de modo a que o novo Código constitua verdadeiro sistema, e não mera consolidação de leis.

Embora não seja propriamente objeto deste trabalho, registra-se que o agravo contra decisão denegatória de recurso especial ou extraordinário também foi objeto de proposta de alteração, pela qual seu prazo de interposição passaria a ser de 15 dias, e voltaria a assumir a forma de instrumento, conforme art. 951, caput e $\S 1^{\circ}$ do anteprojeto. Já o agravo contra decisão monocrática do relator que inadmitir recurso ("agravo interno") vem regulado pelo art. 952, também com alteração do prazo, que passaria a ser de 15 dias.

\subsection{Substitutivo aprovado no Senado Federal E tramitação na CÂMARA dOS DEPUTADOS}

O anteprojeto elaborado pela Comissão de Juristas supra mencionado foi apresentado no Senado Federal em 8.6.2010, tendo recebido a identificação de projeto de 
lei do Senado $n^{o}$ 166/2010, de autoria de José Sarney ${ }^{475}$. Abriu-se brevemente a oportunidade para a formulação de emendas. O projeto foi revisto por comissão técnica de apoio à elaboração do relatório geral composta por Athos Gusmão Carneiro, Cassio Scarpinella Bueno, Dorival Renato Pavan e Luiz Henrique Volpe Camargo.

Ao fim de rápida tramitação, o substitutivo (Emenda $\mathrm{n}^{0}$ 221-CTRCPC) de autoria do Senador Valter Pereira foi aprovado em sessão de 15.12.2010, tendo sido remetido à Câmara dos Deputados em 20.12.2010.

Na Câmara dos Deputados, o Projeto passou a ser identificado como Projeto de Lei $\mathrm{n}^{\mathrm{o}}$ 8.046/2010, tendo sido apensado a outros 139 projetos de lei tratando de Processo Civil, entre eles o Projeto de Lei 6.025/2005 que "[a]ltera o art. 666 da Lei no 5.869, de 11 de janeiro de 1973 - Código de Processo Civil, para dispor acerca da penhora sobre máquinas, instrumentos e implementos agrícolas" ${ }^{\text {476 }}$. Este, por ser o mais antigo em tramitação na Câmara, passou a ter precedência sobre os demais.

Em 31.8.2011, foi instalada Comissão Especial para emitir parecer sobre os projetos de lei mencionados, composta pelos Deputados Fávio Trad (Presidente), Miro Teixeira (Primeiro Vice-Presidente), Vicente Arruda (Segundo Vice-Presidente), Sandra Rosado (Terceira Vice-Presidente), Sérgio Barradas Carneiro (Relator-Geral). Para das mais eficiência aos trabalhos, Efraim Filho, Jerônimo Goergen, Bonifácio de Andrada, Arnaldo Ferias de Sá e Hugo Leal foram eleitos relatores parciais.

Em 19.9.2012, foi apresentado pelo Deputado Sérgio Barradas Carneiro relatório da Comissão Especial destinada a proferir parecer sobre os projetos propondo algumas alterações ao texto aprovado no Senado Federal. Durante a tramitação, o projeto foi debatido em 15 audiências públicas e 13 Conferências Estaduais, tendo sido ouvidos 133 palestrantes especialistas em Processo Civil, além de terem sido apresentadas 900 emendas pelos deputados, segundo informações do próprio relatório ${ }^{477}$.

\footnotetext{
475 Informações obtidas em http://www.senado.gov.br/atividade/materia/detalhes.asp?p cod mate=97249, acesso em 20.7.2011.

476 Ementa do $\quad$ PL $\quad 6.025 / 2005, \quad$ disponível $\quad$ em http://www.camara.gov.br/proposicoesWeb/fichadetramitacao?idProposicao=302638\&ord=1, acesso em 13.1.2013.

${ }^{477}$ Cf. Relatório da Comissão Especial destinada a proferir parecer ao Projeto de Lei $\mathrm{n}^{\mathrm{o}}$ 6.025, de 2005, ao Projeto de Lei $\mathrm{n}^{\circ}$ 8.046, de 2010, ambos do Senado Federal, e outros, que tratam do "Código de Processo Civil" (revogam a Lei no 5.869, de 1973), p. 5.
} 
Referido relatório ainda não foi votado pela Comissão Especial ${ }^{478}$, tampouco pelo Plenário da Câmara dos Deputados, tendo em 27.11.2012 sido apresentado requerimento de prorrogação de prazo de Comissão Temporária ( $n^{\circ}$ 6.433/2012) pela Comissão Especial por vinte sessões.

\subsection{ANÁLISE CRÍTICA DAS MODIFICAÇÕES PROPOSTAS ${ }^{479}$}

\subsubsection{ELIMINAÇÃo DO AGRAVO RETIDO}

Já no anteprojeto elaborado pela Comissão de Juristas, previu-se a eliminação do agravo retido, que foi mantida no projeto aprovado no Senado Federal e pelo relatório apresentado na Câmara, com algumas modificações.

$\mathrm{Na}$ exposição de motivos do anteprojeto, assim se manifestou a Comissão de Juristas: "Desapareceu o agravo retido, tendo, correlatamente, alterado-se o regime das preclusões. Todas as decisões anteriores à sentença podem ser impugnadas na apelação" ${ }^{480}$.

E, em princípio, a julgar pelos parágrafos únicos dos arts. 923 (“As questões resolvidas na fase cognitiva não ficam cobertas pela preclusão e devem ser suscitadas em preliminar de apelação, eventualmente interposta contra a decisão final”) e 929 do anteprojeto, não se vislumbrava a existência de decisões interlocutórias irrecorríveis ("As questões resolvidas por outras decisões interlocutórias proferidas antes da sentença não ficam acobertadas pela preclusão, podendo ser impugnadas pela parte, em preliminar, nas razões ou contrarrazões de apelação").

No Senado, o texto que veio a ser aprovado suprimiu o parágrafo único do art. 929 do anteprojeto (correspondência: art. 969 do PL n 166/2010), tendo sido mantido o parágrafo único do art. 923 do anteprojeto (correspondência: art. 963 do PL nº 166/2010) com pequena alteração: “As questões resolvidas na fase cognitiva, se a decisão a seu respeito não comportar agravo de instrumento, não ficam cobertas pela preclusão e devem

\footnotetext{
${ }^{478}$ Até a data de depósito da presente dissertação, em 22.1.2013.

${ }^{479}$ Importante registrar que o objetivo precípuo deste tópico é a análise crítica das modificações propostas, à luz dos conceitos teóricos desenvolvidos, fugindo ao seu escopo a elaboração de sugestões de lege ferenda.

${ }^{480}$ Anteprojeto cit., p. 27.
} 
ser suscitadas em preliminar de apelação, eventualmente interposta contra a decisão final, ou nas contrarrazões".

Por fim, o relatório apresentado na Câmara dos Deputados manteve em essência a modificação proposta pelo anteprojeto, com pouca modificação na redação (art. 1031, parágrafo único): “As questões resolvidas na fase de conhecimento, se a decisão a seu respeito não comportar agravo, têm de ser suscitadas em apelação, eventualmente interposta contra a decisão final, ou nas contrarrazões, observado o disposto no art. $259^{481}$,

Ao tratar das principais alterações trazidas pelo relatório da Comissão Especial, assim se manifestou sobre o tema o Deputado Sergio Barradas Carneiro: "A extinção do agravo retido não causará maiores problemas no sistema. Com a sugestão de redação feita ao parágrafo único do art. 963 do projeto, deixa-se claro que a parte deve alegar, imediatamente, qualquer nulidade processual que the prejudique, sob pena de preclusão - exatamente a função exercida pelo agravo retido. Adota-se, neste ponto, o regime do processo do trabalho, que funciona bem há anos. Assim, não há decisão interlocutória que fique imune á (sic) preclusão e o sistema se fecha: se o caso for de impugnação com devolução imediata, incide a previsão do agravo de instrumento; se não houver necessidade de impugnação imediata, em razão da inexistência de urgência ou de incompatibilidade de uma impugnação futura, impugnar-se-á a decisão interlocutória na apelação, desde que respeitada a necessidade de prévia alegação da nulidade ${ }^{482}$,

A modificação mais evidente, nesse tocante, diz respeito ao momento para a alegação do inconformismo de modo a evitar a preclusão, que seria a preliminar de apelação ou contrarrazões. Não houve propriamente mudança em relação ao regime de preclusões, mas apenas alteração na oportunidade em que a parte deve impugnar a decisão interlocutória não sujeita a agravo de instrumento, que deixa de ser em dez dias a partir da sua prolação e passa a ser em preliminar de recurso de apelação ou contrarrazões.

\footnotetext{
481 “Art. 259. A nulidade dos atos deve ser alegada na primeira oportunidade em que couber à parte falar nos autos, sob pena de preclusão. Parágrafo único. Não se aplica esta disposição às nulidades que o juiz deva decretar de ofício, nem prevalece a preclusão provando a parte legítimo impedimento.”

${ }^{482}$ Relatório cit., p. 56.
} 


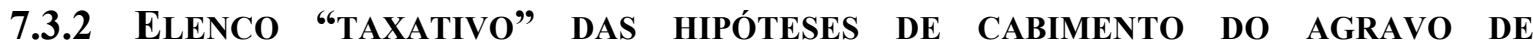 INSTRUMENTO}

Para tentar diminuir o problema do suposto excesso de agravos de instrumento, que desviaria tempo e recursos dos tribunais, atrasando o julgamento de recursos de apelação, aventou-se no anteprojeto elaborado pela Comissão de Juristas o elenco taxativo de hipóteses em que este recurso seria cabível: "O agravo de instrumento ficou mantido para as hipóteses de concessão, ou não, de tutela de urgência; para as interlocutórias de mérito, para as interlocutórias proferidas na execução (e no cumprimento de sentença) e para todos os demais casos a respeito dos quais houver previsão legal expressa. Previu-se a sustentação oral em agravo de instrumento de decisão de mérito, procurando-se, com isso, alcançar resultado do processo mais rente à realidade dos $\operatorname{fatos}^{483,}$.

De acordo com o art. 923 do anteprojeto, o agravo de instrumento seria cabível contra as decisões (i) que versarem sobre tutelas de urgência ou da evidência (a possibilidade vem também prevista no art. 279, parágrafo único); (ii) que versarem sobre o mérito da causa; (iii) proferidas na fase de cumprimento de sentença ou no processo de execução; (iv) em outros casos expressamente referidos neste Código ou na lei.

Ao longo do anteprojeto, encontra-se esparsamente previsto o cabimento do recurso em face das decisões: (i) que resolverem o incidente de desconsideração da personalidade jurídica (art. 65); (ii) que apreciarem o requerimento de gratuidade de justiça (art. 85, $\S 2^{\circ}$ ); (iii) que decidirem incidente de falta de interesse em assistência (art. 322, parágrafo único); (iv) que decidir sobre a negativa do terceiro de exibir documento ou coisa, com fundamento nos arts. 381 e 382, caput, do anteprojeto (art. 382, parágrafo único); (v) que definir o valor a ser pago em liquidação de sentença que condena ao pagamento de quantia (art. 494, $\S 7^{\circ}$ ); (vi) que versarem sobre as pretensões dos credores relativas ao direito de preferência e anterioridade da penhora em cumprimento de sentença (art. 833, parágrafo único); (vii) proferidas em causas em que forem partes, de um lado, Estado estrangeiro ou organismo internacional e, do outro, Município ou pessoa residente ou domiciliada no País (art. 942, parágrafo único).

${ }^{483}$ Anteprojeto cit., p. 27. 
Os artigos 929 a 935 tratam da disciplina do agravo de instrumento, propriamente. Não se observou alteração substancial em relação à estrutura do recurso: continua sendo ônus da parte a formação do instrumento, com peças obrigatórias (cópia da decisão agravada e da respectiva certidão de publicação ou outro documento oficial que comprove a tempestividade do recurso, bem como das procurações outorgadas aos patronos dos litigantes) e facultativas. Para maior clareza, o art. 931, §2 ${ }^{\circ}$ afirma categoricamente que "No prazo do recurso, a petição será protocolada no tribunal, postada no correio sob registro com aviso de recebimento ou interposto por outra forma prevista na lei local".

Outrossim, foi suprimida a menção ao prazo de três dias para a juntada aos autos de origem de cópia da petição de agravo de instrumento, que expressamente passa a ter o único fim de provocar o juízo de retratação pelo magistrado prolator da decisão agravada, desaparecendo sua função de requisito de admissibilidade do julgamento do recurso.

Outra alteração diz respeito ao prazo, que passa a ser de 15 dias úteis, e não mais corridos, conforme art. 907, parágrafo único ("Exceto os embargos de declaração, os recursos são interponíveis em quinze dias úteis"), mantidas, na essência, as demais disposições procedimentais que hoje regem o recurso.

Embora não se confunda com o objeto do presente estudo, registra-se que foi prevista a possibilidade de interposição de agravo interno (art. 936) e de agravo de instrumento contra decisão que inadmite recurso especial ou extraordinário, no prazo de 15 dias (art. 951 do anteprojeto).

No projeto $\mathrm{n}^{\mathrm{o}}$ 166/2010, aprovado no Senado Federal, as hipóteses de cabimento de agravo de instrumento são previstas no art. 969, sendo o recurso interponível contra as decisões que versarem sobre: (i) tutelas de urgência ou da evidência (também contida no art. 271, parágrafo único); (ii) o mérito da causa; (iii) rejeição da alegação de convenção de arbitragem; (iv) incidente de resolução de desconsideração da personalidade jurídica (repetindo-se a autorização do art. 79); (v) gratuidade de justiça (de forma semelhante ao disposto no art. $99, \S 2^{\circ}$ ); (vi) exibição ou posse de documento ou coisa (hipótese prevista ainda no art. 389, parágrafo único); (vii) exclusão de litisconsorte por ilegitimidade; (viii) limitação de litisconsórcio (também prevista no art. 112, §3º); (ix) a 
admissão ou inadmissão de intervenção de terceiros (prevista para a assistência também no art. 309, parágrafo único); e (x) outros casos expressamente referidos em lei.

O parágrafo único do mesmo dispositivo estabelece que “[t]ambém caberá agravo de instrumento contra decisões interlocutórias proferidas na fase de liquidação de sentença, cumprimento de sentença, no processo de execução e no processo de inventário" (em relação às decisões proferidas em cumprimento de sentença, há disposição semelhante no art. 504, parágrafo único; tratando da partilha de dinheiro entre os credores em caso de alegação de insolvência civil, art. 865, parágrafo único).

Além desses casos, manteve-se a previsão de interposição de agravo de instrumento contra as decisões interlocutórias proferidas nas causas em que forem partes, de um lado, Estado estrangeiro ou organismo internacional e, do outro, Município ou pessoa residente ou domiciliada no País (art. 981, parágrafo único).

Acrescentou-se parágrafo ao art. $971\left(\S 3^{\circ}\right)$ para estabelecer que "[a] falta de peça obrigatória não implicará a inadmissibilidade do recurso se o recorrente, intimado, vier a supri-la no prazo de cinco dias", e modificou-se a possibilidade de sustentação oral, que passa a ser permitida "no agravo de instrumento interposto de decisões interlocutórias que sobre tutelas de urgência ou da evidência" (art. 892, V).

Por coerência, relata-se que o agravo interno passou a ser disciplinado pelo art. 975 e o chamado "agravo de admissão" (atualmente conhecido como agravo contra decisão denegatória) se rege pelas disposições do art. 996 pela nova numeração.

Por fim, cabe analisar as disposições concernentes ao agravo de instrumento constantes do relatório apresentado na Câmara dos Deputados.

Dispõe o art. 1037 que cabe agravo contra a decisão interlocutória que (i) conceder ou negar tutela antecipada (do mesmo modo, o art. 280); (ii) versar sobre o mérito da causa (vide também arts. 362 e 364); (iii) rejeitar a alegação de convenção de arbitragem; (iv) decidir o incidente de desconsideração da personalidade jurídica (também no art. 333); (v) negar o pedido de gratuidade da justiça ou acolher o pedido de revogação desse mesmo beneficio (de maneira semelhante, art. 102); (vi) determinar a exibição ou posse de documento ou coisa (disposição semelhante no art. 407, §2ª); (vii) excluir litisconsorte; (viii) limitar o litisconsórcio (no mesmo sentido, art. 114, §7º); (ix) admitir 
ou não admitir de intervenção de terceiros (em relação à assistência, vide art. 317, parágrafo único); (x) versar sobre competência; (xi) determinar a abertura de procedimento de avaria grossa (constante do art. $733, \S 1^{\circ}$ ); (xii) indeferir a petição inicial da reconvenção ou julgá-la liminarmente improcedente (disposição também encontrada no art. 345, $\S 2^{\circ}$ ); (xiii) redistribuir o ônus da prova nos termos do §1o do art. 381; (xiv) converter a ação individual em ação coletiva.

Acrescentou-se segundo parágrafo a esse dispositivo, com a seguinte redação: “A decisão a que se referem (sic) o parágrafo único do art. 362 e o art. 364 também serão impugnáveis por agravo" ${ }^{484}$, correspondendo o parágrafo primeiro ao parágrafo único do art. 969 do projeto aprovado no Senado (relativamente à decisão que trata das pretensões dos exequentes em cumprimento de sentença, também mantida a disposição do projeto $\mathrm{n}^{\circ}$ 166/2010, nos arts. 533, parágrafo único e 934, parágrafo único)

Consolidando as ideias do anteprojeto e do projeto do Senado neste ponto, o art. 959, V, prevê a possibilidade de sustentação oral "no agravo interposto de decisões interlocutórias em que se conceda tutela antecipada ou que versem sobre o mérito da causa".

Previu-se ainda que caberá agravo de instrumento contra a decisão que (i) julgar incidente de suspeição ou impedimento (art. 129, §2 $2^{\circ}$; (ii) acolher ou rejeitar o pedido de parcelamento, pelo devedor, do valor do crédito do exequente, nos termos do art. 941 , caput e $\S 5^{\circ}$; (iii) suspender o curso do processo para o julgamento de recurso representativo de controvérsia no caso de recurso especial ou recurso extraordinário repetitivos, caso o paradigma não corresponda integralmente à controvérsia debatida nos autos (art. $999, \S 5^{\circ}$ e art. $\left.1059, \S 5^{\circ}\right)$

Finalmente, o agravo interno foi disciplinado no art. 1043 e o agravo de admissão está previsto no art. 1064.

\footnotetext{
484 “Art. 362. Ocorrendo qualquer das hipóteses previstas nos arts. 496 e 498, incisos II a V, o juiz proferirá sentença. Parágrafo único. A decisão a que se refere o caput pode dizer respeito a apenas parcela do processo, caso em que poderá ser impugnada por agravo."

"Art. 364. O juiz decidirá parcialmente o mérito, quando um ou mais dos pedidos formulados ou parcela deles: I - mostrar-se incontroverso; II - estiver em condições de imediato julgamento, nos termos do art. 363. $\S 1^{\circ}$. A decisão que julgar parcialmente o mérito poderá reconhecer a existência de obrigação líquida ou ilíquida.

$\S 2^{\circ}$. A decisão que julgar parcialmente o mérito é impugnável por agravo.”
} 
A justificativa para essas mudanças, de acordo com o relatório apresentado à Câmara dos Deputados, foi "estruturar o sistema recursal atribuindo-lhe maior celeridade e efetividade. Buscou-se evitar o excesso de possibilidades de impetração de recursos no primeiro grau de jurisdição." E ainda, “o projeto racionalizou o procedimento de impugnação das decisões em primeiro grau, atribuindo tal função exclusivamente à apelação. Em consequência dessa inovação, as possibilidades de cabimento do agravo de instrumento foram reduzidas, agravo retido foi eliminado do direito processual civil e o regime de preclusões foi remodelado" 485 .

Com o devido respeito, a análise do texto constante do relatório (acima brevemente resumido em seus aspectos principais) demonstra que houve aumento das hipóteses de cabimento do agravo de instrumento na comparação com o anteprojeto e o Projeto de Lei $n^{\circ}$ 166/2010. Nesse contexto, tampouco se pode afirmar que a apelação seria o recurso para a impugnação de decisões interlocutórias proferidas em primeiro grau de jurisdição "exclusivamente".

Mais do que isso, o elenco supostamente taxativo das hipóteses de cabimento de agravo de instrumento inclui a imensa maioria das decisões interlocutórias que podem ser proferidas pelo juiz em primeiro grau de jurisdição, donde não se pode vislumbrar distanciamento grande com o sistema atual de recorribilidade plena.

\subsubsection{DO PONTO DE VISTA DA APROXIMAÇÃO COM O PROCESSO ORAL}

Após a análise do pensamento de GiUseppe Chiovenda a respeito da oralidade, evidente que o modelo proposto pelo processualista italiano se assentava em mais de um pilar. Com efeito, a oralidade tinha por corolários prevalência da palavra dita a viva voz, concentração, imediação, identidade física do juiz e irrecorribilidade das decisões interlocutórias ${ }^{486}$.

No processo civil brasileiro, nem todos esses subprincípios foram adequadamente absorvidos pela prática forense - bastando para os fins desse trabalho a

\footnotetext{
${ }^{485}$ Relatório cit., p. 52.

${ }^{486}$ V. supra, item 5.1 e subitens.
} 
constatação de que isso ocorreu, não sendo necessária a discussão dos motivos pelos quais esse quadro teria se formado.

De outro lado, a leitura dos projetos de reforma do Código de Processo Civil demonstra que se propõe a modificação do regime de recorribilidade das decisões interlocutórias, sem que se pretenda uma aproximação ao modelo de processo oral em relação aos seus outros aspectos - o que demandaria, por exemplo, alteração do modo como as alegações são deduzidas pelas partes e alteração na forma como são conduzidas as audiências. Essas mudanças - muito mais complexas do que a sugerida alteração do regime de recorribilidade das decisões interlocutórias - deveriam ser o cerne de eventual transformação profunda em nosso processo civil.

E, nesse contexto, concorda-se com o pensamento de Heitor SicA, que, considerando aspectos culturais e tradicionais, afirmou que a modificação possível de ser implantada no processo civil brasileiro no sentido de se aproximar ao processo oral idealizado por CHIOvENDA seria insubsistente, e insuficiente para justificar diminuir as possibilidades de recurso em face de decisões interlocutórias ${ }^{487}$.

\subsubsection{DO PONTO DE VISTA DA MODIFICAÇÃo DO SISTEMA DE PRECLUSÕES}

Como já se adiantou, as propostas de reforma legislativa sugerem que a impugnação das decisões interlocutórias que não façam parte do elenco das hipóteses de agravo de instrumento seja feita exclusivamente em preliminar de recurso de apelação ou de contrarrazões a esse recurso.

Dessa forma, possível concluir que a alteração proposta não modificaria sobremaneira o sistema atual, eis que contempla as principais hipóteses de interposição de agravo de instrumento e apenas transportaria as razões de agravo retido para a preliminar de recurso de apelação (em que, pela disciplina vigente, deveriam de toda forma ser reiteradas).

\footnotetext{
487 “(...) o alargamento do princípio da oralidade certamente não possui força suficiente para, enquanto argumento técnico-científico, sustentar proposição de restrição à recorribilidade das interlocutórias. os demais obstáculos para a implementação de um sistema oral (como a questão cultural e o acúmulo de processos) são tão grandes, que não parece lógico pôr em xeque a ampla recorribilidade das interlocutórias apenas em concessão a esse princípio.” Recorribilidade cit., p. 181.
} 
A partir da análise dos dispositivos relativos à recorribilidade das decisões interlocutórias não é possível afirmar tenha havido modificação no sistema de preclusões atualmente vigente, especialmente porque o relatório apresentado à Câmara dos Deputados (versão oficial mais recente dos projetos de alteração do Código de Processo Civil), mantém dois dispositivos que conferem rigidez ao procedimento, os arts. 520 (“Art. 520. Nenhum juiz decidirá novamente as questões já decididas relativas à mesma lide, salvo: I se, tratando-se de relação jurídica continuativa, sobreveio modificação no estado de fato ou de direito; caso em que poderá a parte pedir a revisão do que foi estatuído na sentença; II nos demais casos prescritos em lei") e 522 ("É vedado à parte discutir no curso do processo as questões já decididas a cujo respeito se operou a preclusão”), respectivamente.

A partir desses dispositivos, em que se funda a compreensão atual de que o sistema prevê preclusão tanto para as partes quanto para o juiz, nos termos já expostos em capítulo próprio, é possível afirmar que o procedimento previsto pelo projeto de novo Código de Processo Civil não será mais flexível do que o que se tem atualmente no tocante à recorribilidade das interlocutórias.

O juiz não estará autorizado a rever suas decisões, que seguirão se sujeitando a recursos - de apreciação imediata ou postergada - e as partes terão de interpor os recursos nos momentos oportunos para que suas pretensões possam ser reapreciadas pelos órgãos jurisdicionais de grau superior, não podendo simplesmente reformular as pretensões e reapresentá-las ao juiz.

\subsection{BREVE ANÁliSe da EVOLUÇÃo LEGISLATIVA do AGRAVO: COMPARAÇÃo entre os regimes dos Códigos de Processo Civil de 1939, 1973, o Anteprojeto e o Projeto de novo Código de Processo Civil}

O recurso de agravo sobreviveu até os nossos dias ${ }^{488}$, embora sua evolução não tenha se dado de maneira constante. Para ilustrar, e ao mesmo tempo contextualizar o sempre presente problema da recorribilidade das interlocutórias, tem-se que, no sistema do

\footnotetext{
488 "No direito posterior, tanto em Portugal como no Brasil, a evolução histórica descreveu numerosos meandros e vaivéns, ora abolida esta ou aquela modalidade de agravo, naturalmente com variações também nos respectivos âmbitos de cabimento. Ao tempo das codificações estaduais, subsistiam o agravo de petição e o de instrumento, delimitados os terrenos de um e de outro, em regra, de acordo com critérios casuísticos." J. C. Barbosa Moreira, Comentários cit., p. 478.
} 
Código de Processo Civil de 1939, eram previstas três modalidades do recurso: agravo de petição, de instrumento e nos autos do processo $^{489}$.

A comissão de juristas que se encarregou da elaboração desse diploma havia sido influenciada pela doutrina de CHIOvEnDA, que tinha como um de seus corolários a irrecorribilidade em separado das decisões interlocutórias. Porém, não foi essa a postura adotada pelo Projeto que se converteu no Código de Processo Civil de $1939^{490}$.

Grosso modo, o agravo de petição era cabível contra a decisão terminativa $^{491}$ do processo principal ${ }^{492}$, e as hipóteses de cabimento dos agravos de instrumento e nos autos do processo vinham previstas nos arts. 842 e 851, respectivamente, do revogado diploma processual ${ }^{493}$. Como já se mencionou, no Código de Processo Civil de 1939, previa-se dois recursos para a impugnação de decisões interlocutórias: agravo de instrumento e agravo no auto do processo, sendo que as hipóteses de cabimento de cada um deles estavam previstas nos arts. 842 e 851 , respectivamente.

489 "Em síntese, o sistema recursal adotado pelo estatuto de 1939 era simples. Concedia apelação a todas as
sentenças definitivas que resolvessem o mérito da causa; agravo de petição a todas as decisões que pusessem
termo ao processo sem julgamento do mérito e de algumas interlocutórias mistas. Acolhendo, em parte, a
doutrina de Chiovenda, o Código declarou irrecorríveis as decisões interlocutórias simples, ressalvando
alguns casos para os quais concedeu agravo de instrumento (art. 842) e para outros agravo no auto do
processo (art. 851)." C. S. NoRONHA, Do agravo cit., p. 45, grifos do original.
490 “Deste modo, vitoriosa a segunda corrente, o Projeto definitivo, aprovado pelo Decreto-lei no 1.608 , de 18
de setembro de 1939, contemplou casuisticamente as decisões sobre questões incidentes, passíveis do recurso
de agravo, seguindo, neste particular, toda a legislação anterior, desde as origens do instituto até aquela data.
No art. 842 da codificação revogada estavam disciplinados dezessete casos de agravo de instrumento,
enquanto no art. 851 encontravam-se outras decisões interlocutórias agraváveis no auto do processo." C. S. NORONHA, Do agravo cit., p. 45, grifos do original.

${ }^{491}$ A determinação do que seria uma decisão terminativa é feita negativamente, a partir da conceituação de decisão ou sentença de mérito, que, para A. BUZAID, é o julgamento do conflito de pretensões (lide, no conceito de F. CARNELLUTTI) "mediante o qual o juiz, acolhendo ou rejeitando o pedido, dá razões a uma das partes e nega-a à outra". Uma vez compreendida a ideia de mérito, o jurista paulista explica que "O primeiro pressuposto do recurso [de agravo de petição] é a existência de uma decisão terminativa do processo, isto é, que põe termo ao processo sem lhe resolver o mérito". "[N]essas, o juiz põe termo ao processo por um defeito de sua constituição, ou do procedimento, ou por qualquer outro motivo que torne impossível a decisão da lide; correspondem às interlocutórias com força de definitivas da classificação antiga e às absolutórias da observância do processo.” Do agravo cit., pp. 126, 160 e 156, respectivamente.

${ }^{492}$ Excluídas, assim, segundo A. BUZAID, baseando-se na opinião de E. T. LIEBMAN a respeito, as decisões que encerram incidentes: "O Código usa da expressão processo principal, não para indicar o processo no qual se discute a lide principal, nem como contraposto de processo acessório, mas sim para significar $a$ instância que a decisão terminativa encerra." Do agravo cit., p. 166 - grifos do original.

493 "Desamparava-se o vencido de recurso, neste regime, contra os efeitos das interlocutórias gravosas. Supriram a generalizada aspiração por remédio expedito e eficiente contra as interlocutórias que causassem dano irreparável dois sucedâneos concorrentes: a correição parcial, ou reclamação; e o mandado de segurança, 'embora oblíqua e inadequadamente, a falha e erro do legislador'.” A. DE ASSIS, Manual cit., p. 465. 
O agravo no auto do processo se assemelhava ao atual agravo retido: mediante sua interposição, a parte evitava que incidisse a preclusão sobre a decisão agravada, mas o recurso seria apreciado apenas juntamente com eventual recurso de apelação (arts. 851 e 852, CPC/1939). Esse recurso era cabível contra as decisões que (i) julgavam improcedentes as exceções de litispendência e coisa julgada; (ii) não admitissem a prova requerida ou cercearem, de qualquer forma, a defesa do interessado; (iii) concediam, na pendência da lide, medidas preventivas; (iv) considerassem, ou não, saneado o processo, ressalvando-se, quanto à última hipótese o disposto no art. 846 (que ressalvava o possível cabimento de agravo de instrumento).

Já o agravo de instrumento era cabível em dezesseis situações ${ }^{494}$, contra as decisões que (i) não admitissem a intervenção de terceiro na causa; (ii) julgassem a exceção de incompetência; (iii) denegassem ou concedessem medidas requeridas como preparatórias da ação; (iv) não concedessem vista para embargos de terceiros, ou que os julgarem; (iv) recebessem ou rejeitassem "in limine" os embargos de terceiro; (v) denegassem ou revogassem o benefício de gratuidade; (vi) ordenassem a prisão; (vii) nomeassem ou destituíssem inventariante, tutor, curador, testamenteiro ou liquidante; (viii) arbitrassem, ou deixassem de arbitrar a remuneração dos liquidantes ou a vintena dos testamenteiros; (ix) denegassem a apelação, inclusive de terceiro prejudicado, a julgassem deserta, ou a relevassem da deserção; (x) decidirem a respeito de erro de conta ou de cálculo; (xi) concedessem, ou não, a adjudicação, ou a remissão de bens; (xii) anulassem a arrematação, adjudicação, ou remissão cujos efeitos legais já se tenham produzido; (xiii) admitissem, ou não, o concurso de credores, ou ordenassem a inclusão ou exclusão de créditos; (xiv) julgassem os processos de habilitação incidente em inventário, dinheiro a risco, vistoria de fazendas avariadas, apreensão de embarcações, avaria a cargo do segurador, avarias (em navios), salvados marítimos, e arribadas forçadas, ou os respectivos incidentes, ressalvadas as exceções expressas; (xv) negassem alimentos provisionais; e (xvi) sem caução idônea, ou independentemente de sentença anterior, autorizassem a entrega de dinheiro ou quaisquer outros bens, ou a alienação, hipoteca, permuta, subrogação ou arrendamento de bens (art. 842).

\footnotetext{
${ }^{494}$ Após a supressão do inciso XIV, que previa o cabimento de agravo de instrumento contra as decisões que “que julgarem, ou não, prestadas as contas" pelo Decreto-Lei nº 8.570/1946.
} 
O elenco casuístico das hipóteses de cabimento de cada tipo de agravo, embora fosse tradição herdada do direito português, acabava gerando, na prática, confusão para os aplicadores do direito ${ }^{495}$ - a que ARAKEN DE ASSIS classificou como "sufocante atmosfera" ${ }^{496}$. Ademais, essa enumeração taxativa possuía o inconveniente de não contemplar todas as situações em que a decisão interlocutória era suscetível de causar às partes prejuízo imediato - o que as fez buscar sucedâneos recursais, como o mandado de segurança e a correição parcial.

Para tentar resolver essa situação, a redação primitiva ${ }^{497}$ do Código atualmente vigente modificou o critério de sistematização dos recursos cabíveis ${ }^{498}$. Ao invés de enumerar casuisticamente, previu-se a recorribilidade plena das decisões interlocutórias, mediante agravo de instrumento (que, à época, poderia ser de subida imediata ou retido - diferenciados pelo procedimento para julgamento e, consequentemente, pelo momento de apreciação), sendo facultada ao agravante a opção por uma ou outra espécie do recurso.

Ambas as modalidades de agravo de instrumento eram interpostas perante o juiz prolator da decisão agravada. Se necessário, o instrumento era formado pela serventia

495 “O sistema recursal adotado pelo Código era imperfeito, tendo gerado muitas dissensões doutrinárias, algumas delas ainda não definitivamente estancadas à época de sua substituição pelo novo estatuto. Acompanhando a doutrina, a jurisprudência também vacilou bastante antes de encontrar as soluções mais adequadas aos assuntos polêmicos." C. S. NORONHA, Do agravo cit., p. 44.

496 "A rígida disciplina de ataque às interlocutórias gerou 'sufocante atmosfera' no sistema processual. A contaminação dos meios de respiração das partes derivava, segundo o diagnóstico de autoria conspícua, no 'excessivo simplismo' que negava importância transcendental a algumas decisões, na verdade aptas a influenciarem diretamente o desfecho da causa, ou provocarem dano irremediável á parte, sobrelevando-se 'as providências liminares dos interditos proibitórios'." Manual cit., p. 463.

${ }^{497}$ Relata A. G. CARNEIRO que "a proposta inicial de Buzaid tendia a conservar apenas o agravo de instrumento. No entanto, durante a tramitação legislativa, oportuna emenda restaurou o antigo 'agravo no auto do processo' para aqueles casos em que, não tendo o litigante interesse maior na imediata reforma da decisão interlocutória que lhe fora desfavorável, entende todavia prudente interpor, a fim de evitar preclusão, um recurso com eficácia diferida; ou seja, para ser conhecido e julgado apenas se alguma das partes vier a manifestar apelação e se o agravante requerer expressamente, nas respectivas razões (se for ele o apelante) ou nas contra-razões (se for o apelado), a apreciação do agravo pelo tribunal." Do recurso de agravo cit., p. 115, grifo do original.

498 “Outrossim, o Código atual não seguiu os passos do anterior relativamente à sistematização da matéria recursal. Procurou atribuir a cada espécie de impugnação a tarefa de combater uma ou mais categorias genéricas de atos decisórios, na primeira instância, não levando em conta o valor, alçada ou natureza da causa. Assim, destinou o recurso de apelação não só para atacar as sentenças definitivas sobre o meritum causae, independentemente de valor ou alçada, como para as sentenças terminativas, que extinguem a relação processual sem julgamento de fundo. Do mesmo modo, reservou o agravo de instrumento para ser interposto contra as decisões interlocutórias em geral, sejam simples ou mistas, contenham ou não dano irreparável, declarando irrecorríveis apenas os despachos de mero expediente (art. 504)." C. S. NORONHA, Do agravo cit, p. 47 , grifos do original. 
do juízo, em procedimento cuja demora era por vezes incompatível com a urgência do agravante $^{499}$ - o que complicava a utilização deste recurso para a impugnação das interlocutórias. Por outro lado, a inexistência de efeito suspensivo abria o caminho para a proliferação dos mandados de segurança contra ato judicial com esta finalidade.

Essa solução também não foi isenta de críticas, como a de TOMÁs PARÁ FILHO, para quem a recorribilidade deve estar ligada à aptidão da decisão interlocutória recorrida de causar dano irreparável à parte, não sendo adequadas as opções do Código de Processo Civil de 1939 nem a do Código de $1973^{500}$.

Entretanto, esse regime também se revelou inconveniente na prática, uma vez que o procedimento era excessivamente demorado, especialmente à vista de provimentos antecipatórios ou de urgência. Nesse contexto foi aprovada a Lei $\mathrm{n}^{\mathrm{o}}$ 9.139/1995, que estabeleceu que a interposição seria feita diretamente perante o Tribunal, transferindo à parte a responsabilidade pela formação do instrumento, promovendo "profunda ruptura no sistema brasileiro de propositura de recursos perante o juízo $a$ quo" ${ }^{\prime 01}$. Eliminou-se, assim, a possibilidade, até então existente, de o prolator da decisão agravada decidir sobre a conveniência, para o agravante, de uma ou outra modalidades do recurso, e estabeleceu-se a possibilidade de o relator conceder efeito suspensivo ao recurso.

O novo modelo visava a eliminar o uso anômalo do mandado de segurança para a concessão de efeito suspensivo aos agravos de instrumento interpostos, diminuir a

\footnotetext{
499 "O recurso que mais sofreu alterações, no correr da vigência do Código, foi o agravo. De início, manteve sua clássica configuração. Interposto em primeira instância perante o juiz de primeiro grau, com possibilidade de retratação, subia por traslado, devidamente formalizado pelo escrivão, com peças autenticadas. Permitia-se, no entanto, que o agravo ficasse retido nos autos, para ser decidido como preliminar da apelação, por exclusiva deliberação do agravante.” E. FIDÉLIS DOS SANTOS, Evolução legislativa do sistema recursal de primeiro grau no Código de Processo Civil brasileiro, in A. F. FABRícIO, Meios de impugnação ao julgado civil - estudos em homenagem José Carlos Barbosa Moreira, Rio de Janeiro, Forense, 2007, p. 218.

500 “(...) decisões interlocutórias ou despachos ordinatórios, irrecorríveis no sistema revogado, dos quais, efetivamente, não ressai dano irreparável, passaram a ser impugnáveis, sem proveito substancial, assim à atividade jurisdicional como ao legítimo interesse das próprias partes. Não se compreende essa latitude recursal." E completa: "[a] recorribilidade das interlocutórias simples deve ter, como medida de extensão, a existência, efetiva ou virtual, de prejuízo afetando a posição processual da parte, isto é, envolvendo, ou podendo envolver, direta ou obliquamente, de modo irreparável, o tratamento do objeto do processo e o dos meios conducentes ao seu fim." A recorribilidade cit., pp. 6 e 7 (arquivo virtual).
}

${ }^{501}$ Cf. C. R. DinamarCo, A reforma cit., p. 179. 
utilização do recurso de agravo com fim procrastinatório, e desestimular o uso do agravo de instrumento" $" 502$.

Naquele momento, SÁlvio de Figueiredo TeiXeira afirmou que "[n]ão sendo recomendável extinguir-se esse recurso e nem a sua utilização apenas na modalidade retida, uma vez que maior seria o uso do mandado de segurança em tais hipóteses, fica a certeza que o modelo proposto seria de inegável vantagem em relação ao atual" ${ }^{\text {"503 }}$.

Esse otimismo, contudo, não durou muito. Em artigo publicado em 2002, JoÃo BATISTA LOPES dava conta de que o emprego excessivo do recurso de agravo de instrumento, cujas causas ainda não estariam suficientemente claras, estava prejudicando o julgamento dos recursos de apelação, clamando por nova mudança ${ }^{504}$.

Com a Lei $\mathrm{n}^{0}$ 10.352/2001, tornou-se obrigatória a comunicação da interposição do agravo de instrumento ao juízo prolator da decisão agravada (art. 526 do Código de Processo Civil), sob pena de lhe ser negado seguimento, bem como se estabeleceu a possibilidade de o relator negar seguimento a recurso manifestamente inadmissível, ou dar-lhe provimento, se a decisão agravada estiver em confronto com jurisprudência dominante ${ }^{505}$ (art. 527, I). Também essa lei instituiu a possibilidade de o relator converter o agravo de instrumento em retido (art. 527, II e art. 523, $\S 4^{\circ}$ ) e de conceder antecipação dos efeitos da tutela recursal (art. 527, III).

Comentando essas mudanças, ARAKEN DE ASSIS apontou que a promulgação das leis mencionadas pouco contribuiu para economia de tempo ou para a

\footnotetext{
${ }^{502}$ Cf. S. F. TEIXEIRA, A efetividade cit., p; 237.

${ }^{503}$ A efetividade cit., p. 237.

504 “[N]ão se pode deixar de reconhecer que a alteração do regime do agravo de instrumento já representou um avanço, uma vez que o procedimento anteriormente adotado era notoriamente burocrático e ultrapassado. Entretanto, o aumento excessivo do número de agravos vem gerando, ao menos nas grandes capitais, verdadeiro estrangulamento nas pautas dos tribunais." E continua: "Daí por que se afigurar mais conveniente e adequado alterar o regime do agravo para se adotar, como regra geral, a forma retida e, nos casos de urgência, a interposição perante o órgão de segundo grau." Efetividade cit., p. 133.

${ }^{505}$ Esclarece C. R. DiNAMARCO que "[n]egar seguimento, na dicção do art. 557, é uma locução de grande envergadura, abrangendo hipóteses de recursos desmerecedores de conhecimento, porque lhes falte algum pressuposto de admissibilidade, e recursos desmerecedores de provimento, porque desamparados pelo direito, pela jurisprudência ou pela prova. No art. 557, portanto, negar seguimento é impedir que o recurso siga para a câmara ou turma, em todas hipóteses nas quais ele seja claramente fadado ao insucesso (recursos manifestamente inadmissíveis ou infundados); pelo disposto no $\S 1^{\circ}$-A do art. 557 , o relator poderá também dar provimento ao recurso quando a decisão recorrida estiver em confronto com a jurisprudência dominante." A Reforma da Reforma, 6 a edição, revista e atualizada, São Paulo, Malheiros, 2003, 183.
} 
efetividade almejadas, uma vez que se facilitou a interposição do agravo de instrumento e gerou para o segundo grau de jurisdição carga de trabalho extra ${ }^{506}$.

Foi então promulgada a Lei $\mathrm{n}^{0} 11.187 / 2005$, que instituiu o sistema atualmente vigente, dando-se mais um passo no sentido de privilegiar a impugnação das decisões interlocutórias pela via do agravo retido em detrimento do agravo de instrumento - reservado às decisões passíveis de causar lesão grave e de difícil reparação (no âmbito da fase de conhecimento do processo) ${ }^{507}$.

O recurso de agravo foi, assim, alvo das atenções do legislador reformistas em três oportunidades no período de uma década. E, aparentemente, a julgar pelas propostas de novo Código de Processo Civil, ainda se está buscando sua forma ideal.

Entretanto, antes de prosseguir, é necessária uma observação. Ainda que a atual disciplina do recurso de agravo seja alvo de críticas, certo é que representou avanço em relação às disciplinas anteriores, do ponto de vista da sua eficiência e racionalidade.

Isso porque, da forma como hoje está estruturado, o agravo absorveu funções que antes competiam a outros remédios processuais e, na medida do possível, desestimula o emprego de sucedâneos recursais, justamente em razão da sua ampla abrangência. Para ilustrar, relembra-se que atualmente é possível ao relator conferir efeito suspensivo ou ativo ao agravo de instrumento, eliminando essa que era uma das principais razões pelas quais as partes se valiam de mandado de segurança contra ato judicial.

Outrossim, na linha do que já se adiantou, o agravo é hoje recurso eficiente pois cumpre adequadamente aos dois fins a que se destina no processo: de um lado, promover a revisão da interlocutória e, de outro, evitar que incida sobre a decisão a preclusão, oportunizando ainda o juízo de retratação ao prolator da decisão agravada.

\footnotetext{
506 “É por demais evidente que tudo isto não economiza tempo e pouco contribui para a celeridade global dos processos. Ao contrário, transportou para o segundo grau incidentes dispensáveis e outrora desconhecidos. E, na verdade, o agravo de instrumento realmente se disseminou, qual praga incontrolável, contra todo e qualquer ato do primeiro grau. $\mathrm{O}$ vencido prefere tentar suspender a eficácia da decisão agravada, apostando em sucesso perante o órgão judiciário de segundo grau, em lugar de se conformar ou optar pelo agravo retido. Parece curioso que o discurso oficial, sem embargo de a lei trilhar o caminho inverso, seja o do resgatar da autoridade do juiz de primeiro grau e da eficácia dos seus pronunciamentos." Duração razoável cit., p. 203.

${ }^{507}$ A. G. CARNEIRO assim se manifestou a respeito da modificação: "[n]enhuma maior novidade; na prática, o que realmente ocorreu foi a transferência para o (longo) texto do "novo art. 522 de regras que constavam do (agora revogado) $\S 4^{\circ}$ do art. 523.” Do recurso de agravo cit., p. 121.
} 
Na modalidade retida, provocado o juízo de retratação, o processo segue sem maiores percalços; na modalidade de instrumento, possui desfecho "rápido", num primeiro momento pela previsão legal de análise quase imediata de pedido de efeito suspensivo ou antecipação de tutela recursal pelo relator, mas também por conta da preferência na ordem de julgamento em relação a outros recursos.

No que diz respeito ao processamento do agravo de instrumento, algumas das mudanças operadas pelas leis que reformaram o respectivo procedimento aumentaram sensivelmente a sua eficiência, embora no sistema atual ainda se vislumbre formalismos (especialmente na jurisprudência, como o decorrente da necessidade de comunicação ao juízo a quo da interposição do agravo no prazo de três dias, sob pena de não conhecimento; ou a impossibilidade de sanar vício em relação a peça obrigatória na formação do instrumento). Como exemplos, cita-se a regra de interposição perante o órgão ad quem, e a imposição ao agravante do ônus da formação do instrumento, tudo no prazo de dez dias.

De outro lado, não há como negar a racionalização decorrente da preferência legal pelo agravo retido. Ainda que essa regra não possua, na prática, aplicabilidade tão ampla quanto seria em teoria desejável, é evidente a evolução na comparação com o sistema anterior, que relegava à parte a escolha por um ou outra modalidades. Essa assertiva se funda na ideia de que não existe justificativa para conceder às partes a opção por recurso que não seja absolutamente necessário (agravo de instrumento se não há prejuízo no agravo retido), pois não se poderá puni-las por se valerem dentro dos limites legais dos meios de impugnação à sua disposição.

Se o agravo é atualmente um recurso eficiente, como se procurou demonstrar, e assim o é justamente em razão da sua ampla abrangência, então parece oportuno centrar a atenção na questão da sobrecarga dos tribunais, que tem sido também utilizada como justificativa para as alterações já realizadas e propostas.

Para ilustrar, destaca-se que, de acordo com o relatório "Justiça em Números - Relatório da Justiça Estadual" elaborado pelo Conselho Nacional de Justiça, em 2010, cada magistrado em primeiro grau de jurisdição do estado de São Paulo recebeu 1.903 novos casos, entre processos de conhecimento e execuções de título extrajudicial ${ }^{508}$.

508 Disponível em http://www.cnj.jus.br/programas-de-a-a-z/eficiencia-modernizacao-e-transparencia/pjjustica-em-numeros/relatorios, acesso em 29.9.2012. 
Em segundo grau, no mesmo ano, cada magistrado recebeu 1.193 novos processos, o que representa proporcionalmente $62,69 \%$ do número de processos distribuídos aos juízes.

Reforça-se, contudo, que a análise é meramente ilustrativa, pois o relatório não identifica a que correspondem os "casos" recebidos em segundo grau de jurisdição, não permitindo, assim, a aproximação precisa com o objeto deste estudo, eis que abrange também outros tipos de recursos.

De todo modo, quadro semelhante se verificou em 2009, quando, de acordo com o mesmo relatório elaborado pelo Conselho Nacional de Justiça, cada juiz em primeiro grau de jurisdição recebeu na média 1.998 casos novos, e cada desembargador, 1.260 , ou seja, $63,06 \%{ }^{509}$.

Os números não são baixos, nem em primeiro grau de jurisdição, nem em grau de recurso. No entanto, essas informações convergem para a conclusão já anteriormente enunciada, no sentido de que o problema da pouca efetividade do processo está relacionado mais à falta de estrutura física e material para dar conta do número de demandas do que a razões de ordem legislativa.

Essa conclusão é reforçada pela constatação de que o número de casos distribuídos para cada magistrado por ano é maior do que se poderia razoavelmente esperar que os juízes em primeiro grau de jurisdição fossem capazes de julgar (de acordo com os dados acima, cada magistrado teria de julgar mais de cinco processos por dia apenas para empatar a distribuição), então fica evidente que a reforma do regime de impugnação das decisões interlocutórias não seria a solução adequada. Mais do que isso: poderia vir a significar prejuízo para a qualidade das decisões que não é legítimo impor aos jurisdicionados.

Feito esse breve desvio, tem-se que a análise crítica das disciplinas pretéritas, presente e propostas do recurso de agravo permite observar, em primeiro lugar, que o elenco casuístico das hipóteses de cabimento do recurso é solução sujeita a falhas, pois o direito não tem condições de prever todas as situações em que o meio de impugnação será necessário.

${ }^{509}$ Disponível em http://www.cnj.jus.br/programas-de-a-a-z/eficiencia-modernizacao-e-transparencia/pjjustica-em-numeros/relatorios, acesso em 29.9.2012. 
Em segundo lugar, a impugnação de decisões interlocutórias é um dado da realidade processual empírica, que cabe ao legislador regulamentar cônscio de que não é passível de supressão pela eliminação de determinado meio de impugnação. Em outras palavras, abolir o agravo não impedirá as partes de impugnar decisões interlocutórias; elas apenas terão de encontrar (e encontrarão) novas formas de fazê-lo.

Talvez tenham sido essas as razões que motivaram HeITOR SICA a comparar o estudo da história do agravo ao mito de Prometeu acorrentado, chamando atenção para a dificuldade de encontrar uma solução definitiva para o problema ${ }^{510}$.

Analisando a questão sob outro ângulo, se se considerar que o sistema de recursos é reflexo da estrutura do procedimento em primeiro grau, então é possível estabelecer correlação entre a concentração dos atos em primeiro grau e a restrição aos recursos necessários para assegurar a observância das garantias processuais ao longo do processo, tanto do ponto de vista do número de decisões que serão proferidas (e, portanto, poderiam ser impugnadas), quanto em relação ao tempo transcorrido entre a prolação de decisão interlocutória e a sentença, que estará sujeita a recurso.

A recíproca também é verdadeira, de modo que quanto mais preclusivo o procedimento em primeiro grau (ou seja, quanto mais dividido em fases separadas por decisões), menos se pode restringir as oportunidades de recurso das decisões interlocutórias - até porque estas podem vir a projetar efeitos para fora do processo imediatamente -, como bem explicado por PUOLI ${ }^{511}$.

\footnotetext{
510 “(...) a audácia de Prometeu atraiu a ira de Zeus, que então lhe impôs como castigo ficar, por todo o sempre, acorrentado a uma montanha (o Monte Cáucaso), onde um abutre diariamente devoraria partes do seu fígado, sem matá-lo, dada a capacidade regenerativa desse órgão. Com o agravo não foi diferente: o legislador jamais tencionou exterminá-lo (e nem poderia), mas há mais de um século envia-lhe abutres para enfraquecê-lo (em forma de novos códigos processuais ou de reformas nos diplomas já existentes)". $O$ agravo e o "mito de Prometeu" cit., p. 215.

511 “(...) um procedimento compacto admite que maior restrição seja feita ao cabimento de recursos, eis que, concentrada a atividade decisória do juiz, passa a ser igualmente possível concentrar as possibilidades recursais em direta proporção ao número de decisões que serão proferidas ao longo do feito, podendo-se imaginar, até mesmo, um sistema de recurso único que seja direcionado contra a única decisão que tiver tratado de todas as questões debatidas ao longo da demanda. Em contraposição, acaso o legislador tenha optado por um procedimento dividido em fases a se desenvolverem em sequência e com atividade decisória do juiz apresentada de modo disperso, passa a ser menos aceitável uma excessiva concentração recursal, na medida em que as decisões tomadas pelo juiz podem causar imediato gravame às partes, o que, num contexto de inexistência de recurso, comprometeria a legitimação de um procedimento assim estruturado e aumentaria a sensação de insatisfação com as soluções dadas." Breves considerações sobre o recurso de agravo em vista das inovações trazidas pela Lei 11.187/2005 in L. FUX, N. NERY JR., T. A. A. WAMBIER (coords.), Processo e Constituição - Estudos em homenagem ao Professor José Carlos Barbosa Moreira, $1^{\text {a }}$ edição, São Paulo, 2006, pp. 1043-1044.
} 
O que se nota a partir da análise dos projetos de Código de Processo Civil mencionados é um descompasso entre o procedimento em primeiro grau de jurisdição e o sistema recursal que lhe é correlato, em razão da inexistência de disposições tendentes à concentração do primeiro associada à diminuição (ainda que cada vez menos drástica, com a evolução da tramitação legislativa) das hipóteses de cabimento de agravo.

Essa afirmação é feita sem qualquer cunho valorativo, apenas com a finalidade de salientar que, do ponto de vista da organicidade do sistema, por coerência, à redução das possibilidades de recorrer deveria estar associada a diminuição da precludibilidade, o aumento da concentração, e a previsão de medidas tendentes à redução da duração do procedimento também em primeiro grau. Não é, contudo, o que se nota a partir da leitura dos projetos até agora apresentados a público.

\subsubsection{O PROBLEMA DA UTILIZAÇÃo ANÔMALA DE OUTROS REMÉDIOS PROCESSUAIS COMO SUCEDÂNEOS DO RECURSO CONTRA AS DECISÕES INTERLOCUTÓRIAS}

A análise do quadro existente na vigência do Código de Processo Civil de 1939 leva à constatação de que, à restrição de meios de impugnação das decisões interlocutórias parece estar associado crescimento da utilização anômala de sucedâneos recursais, dos quais se destacam a correição parcial e o mandado de segurança ${ }^{512}$.

Correição parcial é expediente derivado de normas de organização judiciária, destinado a corrigir erros que tumultuassem o processo, que inicialmente

\footnotetext{
512 “O Código de 1939 deu guarida - ainda que relativa - ao princípio da irrecorribilidade das interlocutórias, visto que restringiu fortemente (art. 842) as hipóteses de agravo de instrumento. A reação foi imediata. Entrado em vigor a 10 de março de 1940, já a 31 de outubro o Decreto-lei no 2.726 restabeleceu a correição parcial para o Distrito Federal, do que resulta que o rigor do novo Código perdurou por apenas oito meses. Os Estados seguiram o exemplo e aos poucos a correição parcial (também denominada 'reclamação') tornouse o recurso ('clandestino', como acentuei) apto a contrabalançar o rigor da nova legislação processual." E prossegue: "Mas não é só. Também como contraponto à severidade do legislador federal, a pouco e pouco começou a ser empregado um outro instrumento de controle dos atos praticados pelos juízes, quando se fizesse necessário agir prontamente: o mandado de segurança tornou-se sucedâneo de recurso para situações em que fosse indispensável providência imediata, o que a decisão liminar prevista na lei que o regia tornava possível. A despeito da oposição - máxime em São Paulo - ao emprego desse meio heterodoxo de rever decisões inferiores, sua presença era de tal modo marcante que nem mesmo a Súmula 267 do Supremo Tribunal, que visava a afastá-lo, conseguiu atingir tal resultado, visto que em breve espaço de tempo o rigor que a inspirava foi flexibilizado.” E. D. MonIZ DE ARAGÃo, Demasiados recursos? cit., pp. 181-182. No mesmo sentido, vide A. DE Assis, Manual cit., pp. 465-466; P. H. S. LUCON, O novo regime do agravo, disponível em www.direitoprocessual.org, acesso em 28.7.2011, pp. 24-26 (arquivo eletrônico); H. V. M. SICA, Recorribilidade das interlocutórias cit., pp. 190-194, entre inúmeros outros.
} 
possuía natureza administrativo-disciplinar. Entretanto, com o passar do tempo sua abrangência se ampliou, de modo que passou a ser utilizado como sucedâneo recursal quando não houvesse outro recurso cabível $^{513}$. PAULO LUCON identifica três escopos principais desse instituto: (i) obtenção de providência disciplinar contra o juiz prolator da decisão; (ii) reforma de decisão judicial contra a qual não haja a previsão de recurso; e (iii) corrigir erros e evitar tumultos à marcha processual ${ }^{514}$.

Na vigência do Código de Processo Civil de 1939, muito se debateu acerca do cabimento de mandado de segurança para impugnar ato judicial, especialmente antes do advento da Lei $n^{\circ} 1.533 / 1950$, que regulamentou seu procedimento. Embora tenha havido resistência jurisprudencial - do que é sintomática a edição da súmula 267 do Supremo Tribunal Federal -, na prática essa ação constitucional foi sendo admitida como sucedâneo de recurso para impugnar decisões interlocutórias irrecorríveis, ou para conferir efeito suspensivo a recurso a que a lei não atribuísse diretamente ${ }^{515}$.

Após a promulgação do Código de Processo Civil atualmente vigente, a ampla recorribilidade das decisões interlocutórias reduziu a necessidade de mandado de segurança contra ato judicial, que ficou confinada às hipóteses em que o recurso fosse desprovido de efeito suspensivo ${ }^{516}$.

\footnotetext{
${ }^{513}$ O. BAPTISTA DA SILVA assim define a correição parcial: "expediente destinado a preservar a ordem e o desenvolvimento normal do processo, sempre que este se veja ameaçado por alguma providência judicial manifestamente ilegal, que lhe possa causar desordem ou tumulto processual, ou mesmo como remédio contra a omissão dos juízes que, porventura, descurem de seus deveres funcionais, deixando o feito ao abandono por tempo desmedido, é uma forma de ataque ao ato jurisdicional de que não caiba outro meio de impugnação". Curso cit., p. 474.

514 “a correição parcial é instituto bem mais amplo que a reclamação, já que tem três escopos distintos e bem delineados: i) proporcionar a obtenção de providência disciplinar contra o juiz prolator da decisão (neste caso, aproxima-se da reclamação); ii) reformar decisões judiciais irrecorríveis (aqui, aproxima-se do mandado de segurança); iii) corrigir erros e evitar abusos que invertam ou tumultuem a ordem dos processos, permitindo a regular retomada de sua marcha (finalidade que, por excelência, é da correição parcial)." $O$ novo regime cit., p. 25 (arquivo eletrônico).

${ }^{515}$ Em artigo publicado originalmente em 1984, C. A. BARBI dava conta de que "pode-se afirmar que cessou nos Tribunais a controvérsia sobre o cabimento do mandado contra ato judicial, com o reconhecimento de que ele, em tese, é cabível. O problema que restou, e que é da maior importância, é o de fixar os limites desse cabimento, isto é, determinar quais os atos judiciais atacáveis por essa via e quais as condições para ser admitido esse ataque". Mandado de segurança contra ato judicial, obtido em www.rtonline.com.br, originalmente publicado em Revista de Processo, 24:1984, pp. 24 e seguintes, pp. 1-2 (arquivo eletrônico).

516 “O mandando de segurança contra ato judicial constitui ação autônoma de impugnação que dá ensejo a um processo por meio do qual a parte prejudicada com determinada decisão judicial dela se utiliza com o objetivo de cassar a citada decisão, afastando, por conseqüência, os efeitos dela decorrentes. Entretanto, muito mais que processo ou ação, em termos de atuação sobre o mundo fático, o mandado de segurança é um comando ou ordem que o órgão judiciário dirige à autoridade coatora. Em apertada síntese, é um provimento jurisdicional e sua obtenção fica condicionada à propositura de demanda, ao regular exercício das vias
} 
Celso Agrícola BARBI relata que, no julgamento do recurso extraordinário $\mathrm{n}^{\mathrm{o}}$ 76.909/RS, em 5.12.1973, o Supremo Tribunal Federal admitiu a utilização de mandado de segurança contra ato judicial e condicionou seu cabimento a dois requisitos: “a) a não suspensividade do recurso cabível; b) irreparabilidade do dano real, caracterizada pela impossibilidade objetiva da reparação" ${ }^{\$ 17}$. Prosseguindo no raciocínio, o processualista chega a sustentar seja o mandado de segurança cabível em qualquer hipótese na qual o recurso previsto em lei não seja apto a evitar o dano decorrente de lesão a direito ${ }^{518}$.

Nota-se, então, que à insuficiência de recursos contra decisões interlocutórias, cessando imediatamente o gravame está associada tendência dos Tribunais a permitir a impugnação por outros meios, ainda que não tenha tido evolução constante, porque normalmente ligada às razões e peculiaridades de cada caso concreto ${ }^{519}$. Ainda hoje, admite-se mandado de segurança para a impugnação de decisão teratológica, desde que não haja recurso cabível e não tenha havido trânsito em julgado ${ }^{520}$.

Essas considerações permitem identificar dado fático que não deve ser ignorado, especialmente em momento no qual se discute alteração legislativa com o fim de aprimoramento do sistema processual: se a parte for prejudicada por decisão interlocutória suscetível de lhe causar dano imediato, encontrará meio de impugná-la, quer pela

processuais preestabelecidas e à presença dos pressupostos essenciais ao pronunciamento de mérito.” P. H. S. LUCON, O novo regime cit., p. 20 (arquivo eletrônico).

${ }^{517}$ Mandado de segurança cit., p. 2.

518 "Realmente, onde a lei processual prever um recurso e este for adequado para evitar a lesão do direito da parte, não há razão para se pensar em deixar de usá-lo e lançar mão do mandado de segurança. Mas, quando o recurso previsto em lei não se mostrar apto a evitar a lesão do direito e o conseqüente dano, é legal, constitucional e jurídico que o indivíduo procure no arsenal do direito um outro meio que impeça o perecimento do seu direito e o dano ao seu patrimônio. E esse outro meio pode perfeitamente ser o mandado de segurança. Quando, em uma hipótese como essa, negar-se o uso do mandado de segurança e se deixar ao desamparo o direito e o patrimônio do indivíduo, o preconceito terá excedido seu correto limite e merece censura". Mandado de segurança cit., p. 6 (arquivo eletrônico).

${ }^{519}$ Cf. C. A. BARBI, Mandado de segurança cit., p. 1 (arquivo eletrônico).

520 “Agravo regimental. Agravo de instrumento. Recurso especial. Cabimento. Ausente. Decisão irrecorrível. Cabimento em tese de mandado de segurança contra decisão teratológica ou manifestamente ilegal ou absuiva. Agravo regimental desprovido.” (AgRg no Ag 1307189/SC, Rel. Ministro PAULO DE TARSO SANSEVERINO, TERCEIRA TURMA, julgado em 08/05/2012, DJe 14/05/2012).

No mesmo sentido, vide ainda ementa do agravo regimental no recurso em mandado de segurança 25.104/SP: "É pacífico o entendimento doutrinário e jurisprudencial no sentido de que a impetração de mandado de segurança contra ato judicial somente é admitida em hipóteses excepcionais, tais como decisões de natureza teratológica, de manifesta ilegalidade ou abuso de poder, e capazes de produzir danos irreparáveis ou de difícil reparação à parte impetrante." (AgRg no RMS 25.104/SP, Rel. Ministra DENISE ARRUDA, PRIMEIRA TURMA, julgado em 23/09/2008, DJe 01/10/2008) 
utilização do recurso previsto no sistema especificamente para este fim ou mediante a utilização anômala de algum sucedâneo recursal.

Assim, não parecem ser adequadas nem mesmo em tese as propostas de reduzir dogmaticamente as hipóteses de cabimento de agravo, ou mesmo suprimir a existência desse recurso - dissociadas de quaisquer outras providências -, pois a experiência mostra que as impugnações continuarão existindo e sendo aceitas pelos Tribunais, travestidas em outras formas, chamadas por outros nomes. Isso é o que se procurará demonstrar no próximo tópico. 


\section{Conclusão}

A análise do papel dos recursos no sistema processual revela que, embora sua disciplina possa ser modificada, racionalizada e adaptada à tradição de cada país, há tendência mundial, em praticamente todos os ordenamentos, de se prever meio de revisão das decisões judiciais, sob pena de sujeitar a parte a erro do julgador, ou a decisões proferidas arbitrariamente.

No que tange às decisões interlocutórias, tem-se que algumas são suscetíveis de gerar dano imediato e real à parte. Para estas, dificilmente se poderia prescindir de recurso de apreciação imediata para impugná-las (agravo de instrumento), ante o risco de dano irreparável ou de difícil reparação decorrente da perpetuação da situação criada pela decisão.

Quanto às demais interlocutórias, em que não existe tal risco, por razões sistêmicas, eis que o processo civil brasileiro é rígido, altamente preclusivo e dividido em fases estanques, justifica-se a previsão do agravo retido.

O sistema recursal instituído pela redação originária do Código de Processo Civil atualmente vigente representou, como já se mencionou, simplificação em relação ao que vigorava sob a égide da codificação anterior. Entretanto, a despeito dessa circunstância, frequentemente o atual regime de agravos é apontado como causa de morosidade na entrega da prestação jurisdicional, já tendo sido alvo de reformas e estando novamente na mira do legislador no Projeto de Novo Código de Processo Civil.

Muito se argumenta que a ampla possibilidade de recorrer das decisões interlocutórias atrapalharia ou atrasaria a apreciação dos recursos de apelação, consumindo recursos e energia dos tribunais, que poderiam ser melhor empregados no julgamento de recursos contra sentenças. Daí, pela lógica, a drástica redução ou eliminação dos agravos seria um serviço à prestação jurisdicional célere.

Especialmente nesse grau de abstração, a afirmação evidentemente deve ser analisada com cautela. De todo modo, serve como ponto de partida para se compreender as 
razões pelas quais se entende que o recurso de agravo deveria novamente ter seu regime modificado.

Atualmente, permite-se a ampla recorribilidade das decisões interlocutórias, com a preferência pela utilização do agravo retido, ao menos em teoria. E, ainda que em decorrência de desvio da finalidade da norma (decorrente da circunstância de que as partes comumente preferem o agravo de instrumento ao retido, e pouco se verifica na prática a utilização, pelos julgadores, do dispositivo que permite ao relator a conversão do primeiro no segundo, por decisão irrecorrível), essa opção do ordenamento gera grande volume de trabalho para os tribunais - até porque não é razoável esperar que, tendo à sua disposição mecanismos para impugnar decisões desfavoráveis, as partes deixem de utilizá-los.

Ocorre que, uma vez reconhecida a existência de situações que demandam imediata resposta do Poder Judiciário, em razão do perigo de dano irreparável ou de difícil reparação, ou ainda de perecimento do direito, permitiu-se a antecipação dos efeitos da tutela jurisdicional, mediante juízo de cognição sumária.

Pode-se, com isso, criar situações em que a impugnação pela via do recurso deve ser imediatamente examinada, sob pena de eventual provimento vir a se tornar ineficaz. E, nesse cenário, é até mesmo necessária a existência do recurso de agravo de instrumento, como já se adiantou. Mas, mais do que isso, é também natural que as partes se valham desse mecanismo para tentar afastar de pronto o dano provocado pela decisão judicial que antecipa os efeitos da tutela em favor da parte contrária ${ }^{521}$.

Obviamente, a crise instaurada pela demora na entrega da prestação jurisdicional possui mais de uma causa, não se podendo, num sistema complexo e sujeito a inúmeras variáveis como é o nosso, pretender resolvê-la tão-somente com a modificação do regime de recorribilidade de decisões interlocutórias. Isso implicaria desconsiderar, em

\footnotetext{
${ }^{521}$ Nesse sentido, A. G. CARNEIRO: "Na realidade processual contemporânea as interlocutórias multiplicamse, muitas com efeitos os mais relevantes no andamento e na decisão da causa, impondo-se assim a previsão de um recurso que seja útil à parte que razoavelmente invoque prejuizos dela decorrentes. E nesse passo é mister pondera que, conforme o caso, o emprego do agravo retido poderá revelar-se ineficaz; realmente, é com frequência necessário que o (alegado) gravame seja de logo examinado e (se procedentes as alegações do recorrente) afastado, pois quaisquer providências mais tardias serão inoperantes naquelas hipóteses em que o dano venha a qualificar-se como irreparável, ou de reparação difícil e incompleta." Do recurso de agravo e suas alterações pela lei $n^{o} 11.187 / 05$, in A. F. FABRícIO, Meios de impugnação ao julgado civil estudos em homenagem José Carlos Barbosa Moreira, Rio de Janeiro, 2007, p. 120.
} 
primeiro lugar, que os juízos de primeiro grau estão também assoberbados de trabalho, e que apenas parte da litigiosidade chega aos tribunais na forma de recursos.

Nesse ponto, a comparação realizada a partir do estudo de microssistemas de direito processual (juizados especiais e justiça do trabalho) em que se previu a irrecorribilidade em separado de decisões interlocutórias apresenta resultados reveladores. Com efeito, evidencia-se que a simples promulgação de lei, dissociada das condições materiais para a sua concretização na prática não é apta a resolver o problema da excessiva duração dos processos.

Aparentemente, a reforma pretendida ignora em parte que a irrecorribilidade em separado das decisões interlocutórias é apenas um dos componentes de um modelo. A respeito, pertinente a advertência de CÂNDIDO DinAMARCO, no sentido de que "não se pode impunemente remover as colunas em que todo o edifício assenta, sem outras tão sólidas ali previamente colocar, sob pena de condená-lo à inevitável ruína" ${ }^{22}$.

${ }^{522}$ Princípios e critérios no processo das pequenas causas in K. WATANABE (coord.), Juizado especial de pequenas causas (Lei 7.244, de 7 de novembro de 1984), 1a edição, São Paulo, Revista dos Tribunais, 1985, p. 103. 


\section{BIBLIOGRAFIA}

Allorio, Enrico, Sul doppio grado del processo civile, in Studi in Onori di Enrico Tullio Liebman, v. 3, Milão, 1979.

Alvaro de Oliveira, Carlos Alberto, Efetividade e processo de conhecimento, obtido em www.rtoline.com.br, originalmente publicado em Revista de Processo, 96:1999.

, Os direitos fundamentais à efetividade e à segurança em perspectiva dinâmica in SAlles, CARlos Alberto DE (coord.), As grandes transformações do Processo Civil Brasileiro - Homenagem ao Professor Kazuo Watanabe, São Paulo, Quartier Latin, 2009.

O formalismo-valorativo no confronto com o formalismo excessivo in DIDIER JR., FREDIE (org.), Leituras complementares de processo civil, 8 edição, revisada e ampliada, Salvador, Juspodivm, 2010.

Alves, Francisco Glauber Pessoa, A efetividade como axiologia: premissa obrigatória para um processo célere, in FuX, LuIZ, Nery JR., Nelson, WAMBIER, Teresa Arruda Alvim (coords.), Processo e Constituição - estudos em homenagem ao professor José Carlos Barbosa Moreira, São Paulo, Revista dos Tribunais, 2006.

Alvim, ThereZA, O direito processual de estar em juízo, $1^{\text {a }}$ edição, São Paulo, Revista dos Tribunais, 1996.

Amaral Santos, Moacyr, Primeiras linhas de direito processual civil, v. 3, 24a edição, atualizada por Maria Beatriz Amaral Santos Köhnen, São Paulo, Saraiva, 2010.

Amendoeira JR., Sidnei, Mais uma vez o agravo... in CArmona, Carlos Alberto (coord.), Reflexões sobre a reforma do Código de Processo Civil - Estudos em homenagem a Ada Pellegrini Grinover, Cândido R. Dinamarco e Kazuo Watanabe, $1^{a}$ edição, São Paulo, Atlas, 2007.

Andrade Nery, Rosa Maria (em coautoria), Nery Jr., Nelson, Código de Processo Civil Comentado e legislação extravagante, $10^{\mathrm{a}}$ edição revista, ampliada e atualizada, São Paulo, Revista dos Tribunais, 2007. 
Andrighi, FÁtima Nanci, Primeiras reflexões sobre o pedido de uniformização de interpretação no âmbito dos Juizados Especiais Cíveis e Criminais, in FuX, LuIZ, Nery Jr., Nelson, Wambier, Teresa Arruda Alvim (coords.), Processo $e$ Constituição - estudos em homenagem ao professor José Carlos Barbosa Moreira, São Paulo, Revista dos Tribunais, 2006.

Antunes, Oswaldo Moreira, Recursos na Justiça do Trabalho - Lei n. 7.701, de 21.12.98, São Paulo, LTr, 1997.

Araújo Cintra, Antonio Carlos (em coautoria), Dinamarco, CÂndido Rangel, Grinover, Ada Pellegrini, Teoria Geral do Processo, 20ª edição, São Paulo, Malheiros, 2008.

Arenhart, Sergio Cruz, A antecipação de tutela e as alterações da lei 10.444/2002 in MARINONI, LUIZ GUILHERME (coord), Estudos de direito processual civil Homenagem ao Professor Egas Dirceu Moniz de Aragão, $1^{\text {a }}$ edição, São Paulo, Revista dos Tribunais, 2005.

(em coautoria), MARINONI, LUIZ GuILHERME, Manual do processo de conhecimento, $3^{\mathrm{a}}$ edição, revista e atualizada, São Paulo, Revista dos Tribunais, 2004.

Armelin, Donaldo, Tutela Jurisdicional Diferenciada, Revista de Processo, 65:1992.

Arruda Alvim Netto, José MANOel De, Notas a respeito dos aspectos gerais $e$ fundamentais da existência dos recursos - Direito Brasileiro, Revista de processo, 48:1987.

(em coautoria), Pinto, Teresa Arruda Alvim, Assistência Litisconsórcio, São Paulo, Revista dos Tribunais, 1986.

Assis, Araken de, Manual dos Recursos, $1^{\text {a }}$ edição, São Paulo, Revista dos Tribunais, 2007.

, Duração razoável do processo e reformas da lei processual civil in Fux, LUIZ, Nery Jr., Nelson, Wambier, Teresa Arruda Alvim (coords.), Processo e 
Constituição - Estudos em homenagem ao Professor José Carlos Barbosa Moreira, $1^{\mathrm{a}}$ edição, São Paulo, 2006.

AssumpÇÃo Neves, DANiel Amorim, Preclusão pro judicato e preclusão judicial no processo civil brasileiro, dissertação (mestrado em Direito Processual), Faculdade de Direito - Universidade de São Paulo, São Paulo, 2002.

Baptista da Silva, Ovídio A., Curso de Processo Civil, v. 1, $6^{\mathrm{a}}$ edição, revista e atualizada, São Paulo, Revista dos Tribunais, 2003.

, Da função à estrutura in SAlles, CARlos Alberto de (coord.), As grandes transformações do Processo Civil Brasileiro - Homenagem ao Professor Kazuo Watanabe, $1^{\mathrm{a}}$ edição, São Paulo, Quartier Latin, 2009.

, Os recursos - viés autoritário da jurisdição in Processo e ideologia: o paradigma racionalista, $2^{\mathrm{a}}$ edição, Rio de Janeiro, Forense, 2006.

(em coautoria), Gomes, Fabio, Teoria Geral do Processo Civil, $3^{\mathrm{a}}$ edição revista e atualizada, São Paulo, Revista dos Tribunais, 2002.

Barbi, Celso Agrícola, Barbi, Celso Agrícola, Da preclusão no processo civil, obtido em www.rtonline.com.br, originalmente publicado em Revista Forense, 148:1961.

, Mandado de segurança contra ato judicial, obtido em www.rtonline.com.br, originalmente publicado em Revista de Processo, 24:1984.

Barbosa Moreira, José Carlos, A nova definição de sentença (Lei $n^{o}$ 11.232), Revista Dialética de Direito Processual, 39:2006.

, Breve notícia sobre a reforma do processo civil alemão, obtido em www.rtonline.com.br, originalmente publicado em Revista de Processo, 111:2003.

, Comentários ao Código de Processo Civil, v. 5, $7^{\mathrm{a}}$ edição, Rio de Janeiro, Forense, 1998.

, Conteúdo e efeitos da sentença: variações sobre o tema, Revista de

Processo, 40:1985. 
, Efetividade do processo e técnica processual, obtido em www.rtonline.com.br, originalmente publicado em Revista de Processo, 77:1995. , O futuro da justiça: alguns mitos in Temas de direito processual $-8^{a}$ série, $1^{\text {a }}$ edição, São Paulo, Saraiva, 2004.

, O juízo de admissibilidade no sistema dos recursos civis, tese de concurso para a docência livre de Direito Judiciário Civil apresentada à Congregação da Faculdade de Direito da Universidade do Estado da Guanabara, Rio de Janeiro, 1968.

, O problema da duração dos processos: premissas para uma discussão séria in Temas de direito processual - $9^{a}$ série, $1^{\mathrm{a}}$ edição, São Paulo, Saraiva, 2007.

, Notas sobre o problema da "efetividade" do processo in Temas de direito processual - $3^{a}$ série, $1^{\mathrm{a}}$ edição, São Paulo, Saraiva, 1984.

, Por um processo socialmente efetivo, Revista de Processo, 105:2002.

BECKER, LAÉRCIO, Duplo grau - a retórica de um dogma, in MARINONI, LUIZ GUILHERME, Estudos de Direito Processual Civil - Homenagem ao Professor Egas Dirceu Moniz de Aragão, São Paulo, Revista dos Tribunais, 2005.

Bedaque, José Roberto dos SANTos, Efetividade do processo e técnica processual, $3^{\mathrm{a}}$ edição, São Paulo, Malheiros, 2010.

, Nulidade processual e instrumentalidade do processo, obtido em www.rtonline.com.br, originalmente publicado em Revista de Processo, 60:1990.

, Tutela cautelar e tutela antecipada: tutelas sumárias e de urgência (tentativa de sistematização), $5^{\text {a }}$ edição, São Paulo, Malheiros, 2009.

Bermudes, Sergio, A reforma do Código de Processo Civil, $2^{\text {a }}$ edição, São Paulo, Saraiva, 1996.

, Considerações sobre a nova sistemática do agravo no Código de Processo Civil, in Fabrício, Adroaldo Furtado, Meios de impugnação ao julgado civil - 
estudos em homenagem José Carlos Barbosa Moreira, Rio de Janeiro, Forense, 2007.

Bonet NAVARro, José, Un aporte en el debate sobre la conveniencia de la oralidad especialmente en la práctica de la prueba in La prueba en el proceso civil cuestiones fundamentales, Madri, Difusión Jurídica, 2009.

Borges, Marcos Afonso, Resenha da justiça especial das pequenas causas, in FuX, Luiz, Nery Jr., Nelson, Wambier, Teresa Arruda Alvim (coords.), Processo e Constituição - estudos em homenagem ao professor José Carlos Barbosa Moreira, São Paulo, Revista dos Tribunais, 2006.

Buzaid, Alfredo, Do Agravo de Petição no sistema do Código de Processo Civil, tese (livre-docência em Direito Processual Civil) Faculdade de Direito - Universidade de São Paulo, São Paulo, 1945.

Cais, Fernando Fontoura da Silva, Preclusão e a instrumentalidade do processo, dissertação (mestrado em Direito Processual), Faculdade de Direito - Universidade de São Paulo, São Paulo, 2006.

CAlamandrei, Piero, La casación civil, v. 1, tomo 1, $1^{\text {a }}$ edição, Buenos Aires, Editorial Bibliográfica Argentina, 1945.

Calmon, Petrônio, O modelo oral de processo no século XXI, disponível em http://direitoprocessual.org.br, acesso em 12.3.2012.

Calmon de Passos, José JoAquim, As razões da crise de nosso sistema recursal, in FABricio, Adroaldo FURTAdo (coord.), Meios de impugnação ao julgado civil estudos em homenagem a José Carlos Barbosa Moreira, Rio de Janeiro, Forense, 2007.

, O devido processo legal e o duplo grau de jurisdição, in Revereor estudos jurídicos em homenagem à Faculdade de Direito da Bahia 1891-1981, São Paulo, 1981. 
, O mandado de segurança contra atos jurisdicionais: tentativa de sistematização nos cinquenta anos de sua existência, Revista do Curso de Direito da Universidade Federal de Uberlândia, 14:1985.

CAPpelletti, Mauro, L'oralità nel processo civile italiano: ideale contro realtà in Giustizia e società, v. 11, coleção Diritto e Cultura Moderna, $1^{\mathrm{a}}$ reimpressão da $1^{\mathrm{a}}$ edição, Milão, Edizioni di Comunità, 1977.

, O valor atual do princípio da oralidade, Revista Jurídica, 297:2002, trad. Daniel Ustárroz (originalmente publicado em 1960).

, Parere iconoclastico sulla riforma del processo civile italiano in Giustizia e società, v. 11, coleção Diritto e Cultura Moderna, $1^{\text {a }}$ reimpressão da $1^{\text {a }}$ edição, Milão, Edizioni di Comunità, 1977.

, Procedure orale et procedure écrite, Milão, Dott. A. Giuffrè, 1971.

Carmona, Carlos Alberto, O sistema recursal brasileiro: breve análise crítica, in Alvim, EdUARDO (coord.), Aspectos polêmicos e atuais dos recursos, Revista dos Tribunais, São Paulo, 2000.

CARneiro, Athos GuSMÃo, Da antecipação de tutela, $6^{\mathrm{a}}$ edição, atualizada em conformidade com as leis $\mathrm{n}^{\mathrm{o}} 10.352$, de 26.12.2001, $\mathrm{n}^{\mathrm{o}} 10.358$, de 27.12.2001 e $\mathrm{n}^{\mathrm{o}}$ 10.444, de 07.07.2002, Rio de Janeiro, Forense, 2006.

, Do recurso de agravo e suas alterações pela lei $n^{\circ} 11.187 / 05$, in FABRícIO, Adroaldo Furtado, Meios de impugnação ao julgado civil - estudos em homenagem José Carlos Barbosa Moreira, Rio de Janeiro, Forense, 2007.

, Juizado de pequenas causas in Dinamarco, CÂNDIDO RANGEL, Grinover, Ada Pellegrini, Watanabe, Kazuo (coords.), Participação e processo, $1^{\mathrm{a}}$ edição, São Paulo, Revista dos Tribunais, 1988.

, O novo recurso de agravo e outros estudos, $3^{\mathrm{a}}$ edição, revista e ampliada, Rio de Janeiro, Forense, 1997.

CARnelutti, Francesco, Diritto e processo, Nápoles, Morano, 1958. 
, Instituições do Processo Civil, v. 1, $1^{\mathrm{a}}$ edição, trad. da $5^{\mathrm{a}}$ edição italiana revista e ampliada pelo autor por Adrián Sotero DeWitt Batista, São Paulo, Classic Book, 2000.

, Instituições do Processo Civil, v. 2, $1^{\text {a }}$ edição, trad. Adrián Sotero De Witt Batista, São Paulo, Classic Book, 2000.

Carreira Alvim, José Eduardo, O Novo Recurso de Agravo e Outros Estudos, Rio de Janeiro, Forense, 1996.

, Elementos de teoria geral do processo, $7^{\mathrm{a}}$ edição, Rio de Janeiro, Forense, 1997.

Cavalcante, Jouberto de Quadros Pessoa (em coautoria), Direito processual do trabalho, tomo II, $4^{\mathrm{a}}$ edição, Rio de Janeiro, Lumen Juris, 2009.

Cavallone, Bruno, Forme del procedimento e funzione della prova (ottant'anni dopo Chiovenda), Rivista di diritto processuale, 2:2006.

Cheim Jorge, Flávio, Teoria Geral dos Recursos Cíveis, $3^{\mathrm{a}}$ edição revista e ampliada, São Paulo, Revista dos Tribunais, 2007.

Chiavario, Mario, Processo e garanzie della persona, v. I - Profili istituzionali di diritto processuale, $2^{\mathrm{a}}$ edição, Milão, Dott. A. Giuffrè, 1982.

Chiovenda, Giuseppe, Instituições de Direito Processual Civil, v. 1, $1^{\text {a }}$ edição com notas de Enrico Tullio Liebman, trad. da $2^{\mathrm{a}}$ edição italiana J. Guimarães Menegale, São Paulo, Saraiva, 1942.

, Instituições de Direito Processual Civil, v. 2, 2a edição com notas de Enrico Tullio Liebman, trad. da $2^{\mathrm{a}}$ edição italiana J. Guimarães Menegale, São Paulo, Saraiva, 1965.

, Instituições de Direito Processual Civil, v. 3, $1^{\text {a }}$ edição com notas de Enrico Tullio Liebman, trad. da $2^{\mathrm{a}}$ edição italiana J. Guimarães Menegale, São Paulo, Saraiva, 1945. 
, Principios de Derecho Procesal Civil, tomo I, $1^{\text {a }}$ edição, trad. José Casais y Santaló, Madri, Reus, 1922.

, Principios de Derecho Procesal Civil, tomo II, $1^{\text {a }}$ edição, trad. José Casais y Santaló, Madri, Reus, 1925.

, Procedimento oral, trad. Osvaldo Magon, Revista Forense, 74:1938.

, Saggi di Diritto Processuale Civile (1900-1930), v. 1, nova edição, consideravelmente aumentada, Roma, Foro Italiano, 1930.

, Saggi di diritto processuale civile (1900-1930), vol. 2, nova edição, consideravelmente aumentada, Roma, 1931.

Comoglio, Luigi Paolo (em coautoria), Ferri, Corrado, Taruffo, Michele, Lezioni sul processo civile, $1^{\text {a }}$ edição, Bologna, Il Mulino, 1995.

CorrêA, FÁbio Peixinho Gomes, Direito Processual Civil Alemão in Cruz e TuCCI, José RogÉRIO (coord.), Direito processual civil europeu contemporâneo, $1^{\text {a }}$ edição, São Paulo, Lex, 2010.

COUCHEZ, GÉRARD, Procédure civile, 4ª edição, Paris, Sirey, 1986.

COUTURe, Eduardo JuAn, Fundamentos del derecho procesal civil, $3^{\mathrm{a}}$ edição (póstuma), Buenos Aires, Roque Depalma, 1958.

, Las garantias constitucionales del proceso civil, in Estudios de Derecho Procesal Civil, tomo I, 1a edição, Buenos Aires, Ediar, 1948.

Cretella Neto, José, Fundamentos principiológicos do processo civil, $2^{\mathrm{a}}$ edição, Rio de Janeiro, Forense, 2006.

CRUZ e TuCCI, José RogÉRIO, A causa petendi no direito processual civil brasileiro, v. 27, Coleção Estudos de Direito de Processo Enrico Tullio Liebman, $2^{\mathrm{a}}$ edição revista, atualizada e ampliada, São Paulo, Revista dos Tribunais, 2001.

Diretrizes do novo processo civil italiano, obtido em www.rtonline.com.br, originalmente publicado em Revista de Processo, 69:1993. 
, Garantia da prestação jurisdicional sem dilações indevidas como corolário do devido processo legal in CRUZ E TUCCI, José RogéRIO, TUCCI, RogéRIo LAURIA, Devido processo legal e tutela jurisdicional, $1^{\text {a }}$ edição, São Paulo, Revista dos Tribunais, 1993.

, Jurisdição e poder (contribuição para a história dos recursos cíveis), $1^{\mathrm{a}}$ edição, São Paulo, Saraiva, 1987.

, Precedente judicial como fonte do direito, São Paulo, Revista dos Tribunais, 2004.

, Sobre a eficácia preclusiva da decisão declaratória de saneamento, Revista dos Tribunais, 640:1989.

, Tempo e processo - uma análise empírica das repercussões do tempo na fenomenologia processual (civil e penal), $1^{\text {a }}$ edição, São Paulo, Revista dos Tribunais, 1997.

Dall'Agnol, Antonio, Comentários ao Código de Processo Civil, v. 2, $2^{\text {a }}$ edição revista, atualizada e ampliada, São Paulo, Revista dos Tribunais, 2007.

DinAmarco, CÂNDIDo RANGel, $A$ instrumentalidade do processo, $14^{\mathrm{a}}$ edição, revista e atualizada, São Paulo, Malheiros, 2009.

, A lei das pequenas causas e a renovação do processo civil in WATANABE, KAZUO (coord.), Juizado especial de pequenas causas (Lei 7.244, de 7 de novembro de 1984), $1^{\mathrm{a}}$ edição, São Paulo, Revista dos Tribunais, 1985.

, A reclamação no processo civil brasileiro in Nova Era do Processo Civil, $1^{\mathrm{a}}$ edição, São Paulo, Malheiros, 2003.

, A reforma da Reforma, $6^{\mathrm{a}}$ edição, revista e atualizada, São Paulo, Malheiros, 2003.

, A reforma do Código de Processo Civil, $3^{\mathrm{a}}$ edição revista, ampliada e atualizada, São Paulo, Malheiros, 1996 
, Aceleração dos procedimentos in Fundamentos do processo civil moderno, v. 2, 4ª edição, São Paulo, Malheiros, 2001.

, Ação rescisória contra decisão interlocutória in Nova era do Processo Civil, $1^{\text {a }}$ edição, São Paulo, Malheiros, 2003.

,Instituições de Direito Processual Civil, v. 2, $1^{\text {a }}$ edição, São Paulo, Malheiros, 2001.

, Instituições de Direito Processual Civil, v. 3, $1^{\text {a }}$ edição, São Paulo, Malheiros, 2001

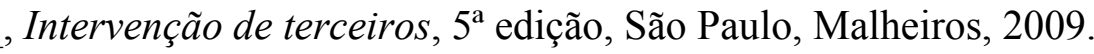

, Manual das pequenas causas, $1^{\mathrm{a}}$ edição, São Paulo, Revista dos Tribunais, 1986.

, O futuro do processo civil brasileiro in Fundamentos do processo civil moderno, tomo II, $4^{\mathrm{a}}$ edição, São Paulo, Malheiros, 2001.

, O processo no juizado das pequenas causas in WATANABE, KAZUO (coord.), Juizado especial de pequenas causas (Lei 7.244, de 7 de novembro de 1984), $1^{\mathrm{a}}$ edição, São Paulo, Revista dos Tribunais, 1985.

, Os efeitos dos recursos in Nova era do Processo Civil, $1^{\text {a }}$ edição, São Paulo, Malheiros, 2003.

, Princípios e critérios no processo das pequenas causas in WATANABE, KAZUO (coord.), Juizado especial de pequenas causas (Lei 7.244, de 7 de novembro de 1984), $1^{\mathrm{a}}$ edição, São Paulo, Revista dos Tribunais, 1985.

(em coautoria), Araújo Cintra, Antonio CARlos, Grinover, AdA Pellegrini, Teoria Geral do Processo, 20ª edição, São Paulo, Malheiros, 2008.

, Tutela jurisdicional, obtido em www.rtonline.com.br, originalmente publicado em WAmbier, Luiz Rodrigues e WAmbier, teresa ArRuda Alvim (coords.), Doutrinas Essenciais de Processo Civil, v. 1, São Paulo, Revista dos Tribunais, 2011. 
EsteVes, CAROlina Bonadiman, (Ir)recorribilidade imediata de decisões interlocutórias: análise crítica de suas consequências no processo civil brasileiro e proposta para o alcance da efetividade da tutela jurisdicional, tese (doutorado em Direito Processual), Faculdade de Direito - Universidade de São Paulo, São Paulo, 2006.

FAsching, Hans WALter, A posição dos princípios da oralidade e da imediação no processo civil moderno, Revista de processo, 39:1985, trad. Wanderlei de Paulo Barreto.

Ferri, Corrado (em coautoria), Comoglio, Luigi Paolo, TARUffo, Michele, Lezioni sul processo civile, $1^{\text {a }}$ edição, Bologna, Il Mulino, 1995.

FIDÉLIS DOS SANTOS, ERNANE, Evolução legislativa do sistema recursal de primeiro grau no Código de Processo Civil brasileiro, in A. F. FABRíCIO, Meios de impugnação ao julgado civil - estudos em homenagem José Carlos Barbosa Moreira, Rio de Janeiro, Forense, 2007. , Novos perfis do processo civil brasileiro, Belo Horizonte, Del Rey, 1996.

FigueIRA JÚNIOR, Joel Dias, Manual dos juizados especiais cíveis estaduais e federais, $1^{\text {a }}$ edição, São Paulo, Revista dos Tribunais, 2006.

(em coautoria), Tourinho Neto, Fernando DA Costa, Juizados Especiais Federais Cíveis e Criminais (Comentários à Lei 10.259, de 10.07.2001), $2^{\mathrm{a}}$ edição revista, atualizada e ampliada, São Paulo, Revista dos Tribunais, 2007.

Frederico Marques, José, Instituições de direito processual civil, v. 4, Campinas, Millenium, 2000.

, Manual de direito processo civil, v. 1, 1ª edição, Campinas, Bookseller, 1997.

, Manual de Direito Processual Civil, v. 3, 2a edição atualizada, Campinas, Millennium, 1998.

Frocham, MANuel IBAÑEZ, Los recursos en el proceso civil: provincia de Buenos Aires, $1^{\mathrm{a}}$ edição, Buenos Aires, Soc. Bibl. Argentina, 1943. 
FuRMANn, IVAN, Os limites da oralidade como forma 'adequada' de produzir verdade no direito, Revista de estudos jurídicos - UNESP, 22:2011.

GALANTER, MARC, Introduction: compared to what? Assessing the quality of dispute resolution, disponível em www.marcgalanter.net, acesso em 31.12.2012.

GaLlet, JeAn-Louis, La procédure civile devant la cour d'appel, $2^{\mathrm{a}}$ edição, Paris, Lexis Nexis Litec, 2010.

Gajardoni, Fernando Da FonseCA, O princípio constitucional da tutela jurisdicional sem dilações indevidas e o julgamento antecipadíssimo da lide (art. 285-A do CPC), in Salles, Carlos Alberto De (coord.), As grandes transformações do Processo Civil Brasileiro - Homenagem ao Professor Kazuo Watanabe, $1^{\text {a }}$ edição, São Paulo, Quartier Latin, 2009.

García, Eduardo Augusto, La oralidad en el processo civil, in Antología Jurídica cuadernos mensuales, 264:1940.

,El juicio oral en lo Civil y Comercial, Revista Forense, 74:1938.

Garcia Medina, José Miguel (em coautoria), Wambier, Teresa Arruda Alvim, Recursos e Ações Autônomas de Impugnação, v. 2, coleção Processo Civil Moderno, São Paulo, Revista dos Tribunais, 2008.

Gaulia, Cristina Tereza, Juizados Especiais Cíveis - o espaço do cidadão no Poder Judiciário, Rio de Janeiro, Renovar, 2005.

Geraldes, António SAntos Abrantes, Recursos em processo civil: abordagem crítica da última reforma, Lisboa, 2010, disponível em http://cjlp.org/materias/recursos_processo_civil_abordagem_critica_ultima_reforma. html, acesso em 28.2.2011.

, Recursos em Processo Civil - novo regime, $2^{\mathrm{a}}$ edição revista e atualizada, Coimbra, Almedina, 2008.

Gerbay, Nicolas (em coautoria), Gerbay, Philippe, Guide du Procès Civil en appel, $1^{\mathrm{a}}$ edição, Paris, Lexis Nexis, 2012. 
Gerbay, PhilipPe (em coautoria), Gerbay, Nicolas, Guide du Procès Civil en appel, $1^{\mathrm{a}}$ edição, Paris, Lexis Nexis, 2012.

Giglio, Wagner D., Direito processual do trabalho, $10^{\mathrm{a}}$ edição revista e ampliada, São Paulo, Saraiva, 1997.

GiUdiCEANDREA, NiCOLA, Le impugnazioni civili, vol. 1, $1^{\text {a }}$ edição, Milão, Giuffre, 1952.

Goldschmidt, JAMES, Derecho Procesal Civil, $1^{\mathrm{a}}$ edição, trad. da $2^{\mathrm{a}}$ edição alemã, por Leonardo Prieto Castro, Barcelona, Labor, 1936.

Gomes, Luiz FlÁvio, Efeitos da preclusão pro judicato no processo penal, Revista dos Tribunais, 810:2003.

Gonçalves Filho, José Geraldo, O princípio constitucional da eficiência no Processo Civil, tese (doutorado em Direito Processual Civil), Faculdade de Direito Universidade de São Paulo, São Paulo, 2010.

GouvêA, José roberto F. (em coautoria), Negrão, Theotonio, Código de Processo Civil e legislação processual em vigor, 40a edição comemorativa, São Paulo, Saraiva, 2008.

Greco, Leonardo, Princípios de uma teoria geral dos recursos, in Revista eletrônica de direito processual, Rio de Janeiro, 5:2010.

Greco Filho, Vicente, Da Intervenção de Terceiros, 3ª edição, São Paulo, Saraiva, 1991.

Grinover, Ada Pellegrini, Aspectos constitucionais dos juizados de pequenas causas in WATANABE, KAZUO (coord.), Juizado especial de pequenas causas (Lei 7.244, de 7 de novembro de 1984), $1^{\mathrm{a}}$ edição, São Paulo, Revista dos Tribunais, 1985.

, O conteúdo da garantia do contraditório in Novas tendências do direito processual de acordo com a Constituição de 1988, $2^{\text {a }}$ edição, São Paulo, Forense Universitária, 1990.

, Os princípios constitucionais e o Código de Processo Civil, São Paulo, Bushatsky, 1975. 
(em coautoria), Araújo Cintra, Antonio Carlos, Dinamarco, Cândido

Rangel, Teoria Geral do Processo, 20ª edição, São Paulo, Malheiros, 2008.

, Um enfoque constitucional da teoria geral dos recursos in $O$ processo em evolução, $1^{\text {a }}$ edição, Rio de Janeiro, Forense Universitária, 1996.

GuASP, JAIME, Derecho Procesal Civil, $4^{\mathrm{a}}$ edição, revisada e adaptada à legislação vigente por Pedro Aragoneses Alonso, Madri, Civitas, 1998.

Guedes, Clarissa Dinis, A impugnação das decisões interlocutórias no direito lusitano, Revista eletrônica de direito processual, 4:2009.

Guedes, JefFERSON CARÚs, O princípio da oralidade - procedimento por audiências no Direito Procesual Civil Brasileiro, v. 53, coleção Estudos de Direito de Processo Enrico Tullio Liebman, São Paulo, Revista dos Tribunais, 2003.

Guillén, Victor Fairén, Teoria general del Derecho Procesal, $1^{\text {a }}$ edição, Universidad Nacional Autónoma de México, Cidade do México, 1992.

, Doctrina general de los medios de impugnación y parte general del derecho procesal, in Estudios de Derecho Procesal, Madri, Editorial Revista de Derecho Privado, 1955.

Guinchard, Serge (em coautoria), Vincent, Jean, Procédure civile, 20 a edição, Paris, Dalloz, 1981.

Guimarães, Luis Machado, O processo oral e o processo escrito, Revista Forense, $74: 1938$.

Hoffman, Paulo, Razoável duração do processo, $1^{\text {a }}$ edição, São Paulo, Quartier Latin, 2006.

Iura, AleXandre Miura, Oralidade e escrita no Processo Civil, dissertação apresentada à Faculdade de Direito do Largo de São Francisco para a obtenção do título de mestre sob a orientação do Prof. José Rogério Cruz e Tucci, 2012. 
JAUERnig, OThmar, Direito processual civil, $1^{\text {a }}$ edição trad. da $25^{\text {a }}$ edição alemã totalmente refundida, da obra criada por Friedrich Lent por F. Silveira Ramos, Coimbra, Almedina, 2002.

Jorge Neto, Francisco Ferreira (em coautoria), Cavalcante, Jouberto de Quadros Pessoa, Direito processual do trabalho, tomo II, $4^{\text {a }}$ edição, Rio de Janeiro, Lumen Juris, 2009.

Lacerda, Galeno, Despacho saneador, $3^{\mathrm{a}}$ edição, Porto Alegre, Porto Alegre, Sergio Antonio Fabris, 1990.

Laspro, Oreste Nestor de SouzA, Alguns aspectos dos recursos no Juizado Especial Cível, Revista do Advogado, 50:1997.

, Devido processo legal e a irreversibilidade da antecipação dos efeitos da tutela jurisdicional in MARINONI, LUIS GUILHERME (coord.), Estudos de direito processual civil - Homenagem ao Professor Egas Dirceu Moniz de Aragão, $1^{\text {a }}$ edição, São Paulo, Revista dos Tribunais, 2005.

, Duplo grau de jurisdição no direito processual civil, v. 33, coleção Estudos de Direito de Processo Enrico Tullio Liebman, São Paulo, Revista dos Tribunais, 1995. , Oralidade e duplo grau de jurisdição, Revista do Advogado, São Paulo, 40:1993. , Os recursos ordinários na reforma do Código de Processo Civil, Revista do Advogado, 46:1995.

Leal, Vitor Nunes, Ignorância, rotina e chicana - os três maiores inimigos do Processo Oral, Revista Forense, 74:1938.

LiEbman, EnRico Tullio, Eficácia e autoridade da sentença e outros escritos sobre a coisa julgada, com notas relativas ao direito brasileiro vigente por Ada Pellegrini Grinover, $2^{\mathrm{a}}$ edição, Rio de Janeiro, Forense, 1981.

, Manual de direito processual civil, trad. Cândido Rangel Dinamarco, v. 1, $3^{\mathrm{a}}$ edição, São Paulo, Malheiros, 2005. 
Lobo da Costa, Moacyr, O agravo no direito lusitano in Azevedo, Luiz Carlos de, LOBO DA COSTA, MoACYR, Estudos de história do processo - recursos, $1^{\mathrm{a}}$ edição, São Paulo, Joen e FIEO, 1996.

, Origem do agravo no auto do processo in AzEvedo, Luiz CARLos DE, LOBO DA COSTA, MOACYR, Estudos de história do processo - recursos, $1^{\mathrm{a}}$ edição, São Paulo, Joen e FIEO, 1996.

LOPES, JoÃo BATISTA, Breves considerações sobre o instituto da preclusão, obtido em www.rtonline.com.br, originalmente publicado em Revista de Processo, 23:1981.

- Efetividade da tutela jurisdicional à luz da constitucionalização do processo civil, Revista de Processo, 116:2004.

- Efetividade do processo e reforma do Código de Processo Civil: como explicar o paradoxo processo moderno - Justiça morosa?, Revista de Processo, 105:2002.

Lorencini, Marco Antonio Garcia Lopes, Juizado Especial Cível: o direito processual revisitado, dissertação (mestrado em Direito Processual), Faculdade de Direito do Largo - Universidade de São Paulo, São Paulo, 2002.

Lucon, Paulo Henrique dos Santos, O novo regime do agravo, disponível em www.direitoprocessual.org, acesso em 28.7.2011.

, Sentença e liquidação no CPC (Lei 11.232/2005) in FuX, LuIZ, NERY JR., NELSON, Wambier, Teresa Arruda Alvim (coords.), Processo e Constituição - Estudos em homenagem ao professor José Carlos Barbosa Moreira, São Paulo, Revista dos Tribunais, 2006.

Machado Guimarães, L. O processo oral e o processo escrito, Revista Forense, 74: 1938.

Mandrioli, Crisanto, Corso di Diritto Processuale Civile, v. 2, Editio Minor, Torino, G. Giappichelli, 2000.

Marcato, Ana CÂndida Menezes, O princípio do duplo grau de jurisdição e a reforma do Código de Processo Civil, $1^{\text {a }}$ edição, São Paulo, Atlas, 2006. 
Marcato, Antonio Carlos, Preclusões: limitação ao contraditório?, obtido em www.rtonline.com.br, originalmente publicado em Revista de Processo, 17:1980.

MARINONI, LUIZ GUILHERME, $A$ antecipação da tutela, $6^{\mathrm{a}}$ edição, revista e ampliada, São Paulo, Malheiros, 2000.

(em coautoria), Arenhart, Sergio CRUZ, Manual do processo de conhecimento, $3^{\mathrm{a}}$ edição, revista e atualizada, São Paulo, Revista dos Tribunais, 2004.

(em coautoria), Mitidiero, DANIEL, O projeto do CPC-crítica e propostas, $1^{\mathrm{a}}$ edição, São Paulo, Revista dos Tribunais, 2010.

Martins, Pedro Batista, Sôbre o Projéto de Codificação do Processo Civil e Comercial, Revista Forense, 74:1938.

Martins, Sergio Pinto, Direito processual do trabalho - doutrina e prática forense, $28^{\mathrm{a}}$ edição, São Paulo, Atlas, 2008.

Mascaro Nascimento, Amauri, Curso de direito processual do trabalho, $17^{\mathrm{a}}$ edição, ampliada e atualizada, São Paulo, Saraiva, 1997.

Mendonça Lima, AlCides De, A recorribilidade dos despachos interlocutórios no Código de Processo Civil brasileiro in Estudios jurídicos en memoria de Eduardo J. Couture, Montevideo, Altuna, 1957.

, Introdução aos recursos cíveis, $2^{\mathrm{a}}$ edição, São Paulo, Revista dos Tribunais, 1976.

, Recursos Trabalhistas, tomo I, coleção Philadelpho Azevedo, São Paulo, Max Limonad, 1956.

, Recursos Trabalhistas, tomo II, coleção Philadelpho Azevedo, São Paulo, Max Limonad, 1956.

MigliazZA, MARIA, Il doppio grado di giurisdizione nel diritto delle Comunità europee, $1^{\mathrm{a}}$ edição, Milão, Franco Angeli, 1993.

Milhomens, Jônatas, Dos recursos cíveis, $1^{\text {a }}$ edição, Rio de Janeiro, Forense, 1991. 
Miranda, Gilson Delgado, (em coautoria) Pizzol, Patrícia Miranda, Recursos no processo civil, 6 a edição atualizada, São Paulo, Atlas, 2009.

Mitidiero, Daniel (em coautoria), Marinoni, Luiz Guilherme, O projeto do CPC crítica e propostas, $1^{\text {a }}$ edição, São Paulo, Revista dos Tribunais, 2010.

Moniz de Aragão, Egas Dirceu, Demasiados recursos?, in Fabricio, Adroaldo FURTADO (coord.), Meios de impugnação ao julgado civil - estudos em homenagem a José Carlos Barbosa Moreira, Rio de Janeiro, Forense, 2007.

, Embargos de nulidade e infringentes do julgado, $1^{\text {a }}$ edição, São Paulo, Saraiva, 1965.

Moraes, Silvana Campos, Juizado Especial Cível, Rio de Janeiro, Forense, 1998.

Morato, Francisco, A oralidade, Revista Forense, 74:1938.

Mortara, Lodovico, Appello civile in Digesto Italiano, v. 3, parte $2^{\mathrm{a}}$, Turim, Unione Tipografico, 1890.

Negrão, Theotonio (em coautoria), Gouvêa, José roberto F., Código de Processo Civil e legislação processual em vigor, 40a edição comemorativa, São Paulo, Saraiva, 2008.

Nery Jr., Nelson (em coautoria), Andrade Nery, Rosa Maria, Código de Processo Civil Comentado e legislação extravagante, $10^{\mathrm{a}}$ edição revista, ampliada e atualizada, São Paulo, Revista dos Tribunais, 2007.

, Princípios do Processo na Constituição Federal, $9^{\mathrm{a}}$ edição, revista, ampliada e atualizada com as novas Súmulas do STF (simples e vinculantes) e com análise sobre a relativização da coisa julgada, São Paulo, Revista dos Tribunais, 2009.

, Teoria Geral dos Recursos, v. 1, coleção Recursos no Processo Civil, 6 a edição, São Paulo, Revista dos Tribunais, 2004.

Neves, Celso, Estrutura fundamental do processo civil - tutela jurídica processual, ação, processo e procedimento, $2^{\mathrm{a}}$ edição, $2^{\mathrm{a}}$ tiragem, Rio de Janeiro, Forense, 1997. 
Nogueira, Maurício José, Duplo grau de jurisdição: aspectos constitucionais e reflexos processuais, in Fux, Luiz, Nery Jr., Nelson, e WAmbier, Teresa Arruda Alvim (coords.), Processo e Constituição - Estudos em homenagem ao Professor José Carlos Barbosa Moreira, São Paulo, Revista dos Tribunais, 2006.

Noronha, Carlos Silveira, Do agravo de instrumento, $3^{\mathrm{a}}$ edição, Rio de Janeiro, Forense, 1995.

Novelli, Giovanni (em coautoria), Petitti, Stefano, Codice di procedura civile annotato con la giurisprudenza, Milão, Giuffre, 2007.

Oliveira, Pedro Miranda de, Princípios constitucionais do processo civil no âmbito recursal in Fux, Luiz, Nery JR., Nelson, Wambier, Teresa Arruda Alvim (coord.), Processo e Constituição - Estudos em homenagem a José Carlos Barbosa Moreira, $1^{\text {a }}$ edição, São Paulo, Revista dos Tribunais, 2006.

Orestano, RicCARDo, L'appello civile in diritto romano, $2^{\mathrm{a}}$ edição ampliada, Turim, G. Giapichelli, 1953.

Othon Sidou, J. M., A recepção da oralidade no sistema processual brasileiro, Revista do Curso de Direito da Universidade Federal de Uberlândia, Uberlândia, 14:1985.

Pacífico, Luiz Eduardo Boaventura, Direito Processual Civil Italiano in Cruz E TuCCI, José Rogério (coord.), Direito Processual Civil Europeu Contemporâneo, $1^{\text {a }}$ edição, São Paulo, Lex, 2010.

PARÁ Filho, TOMÁs, A recorribilidade das decisões interlocutórias no novo Código de Processo Civil, obtido em www.rtonline.com.br, originalmente publicado em Revista de Processo, 5:1977.

PERrot, Roger, Le principe du double degré de jurisdiction et son evolution en droit judiciaire privé français, in Studi in onore di Enrico Tullio Liebman, v. 3, Milão, 1979.

Petitti, Stefano (em coautoria), Novelli, Giovanni, Codice di procedura civile annotato con la giurisprudenza, Milão, Giuffre, 2007.

PINTO, BILAC, O sentido da reforma, Revista Forense, 74:1938. 
Pinto, Júnior AleXANDre MoreirA, Sistemas rígidos e flexíveis: a questão da estabilização da demanda in Bedaque, José Roberto dos SAntos, Cruz e Tucci, José RoGÉRIO (coords.), Causa de pedir e pedido no processo civil (questões polêmicas), São Paulo, Revista dos Tribunais, 2002.

Pinto, Teresa Arruda Alvim (em coautoria), Arruda Alvim Netto, José Manoel, Assistência - Litisconsórcio, São Paulo, Revista dos Tribunais, 1986.

Pizzol, Patrícia Miranda (em coautoria), Miranda, Gilson Delgado, Recursos no processo civil, 6 a edição atualizada, São Paulo, Atlas, 2009.

Pizzorusso, Alessandro, Doppio grado di giurisdizione e principi costituzionali, Rivista di diritto processuale, 1:1978.

Poittevin, Ana Laura GonzÁlez, Recorribilidade das decisões interlocutórias - uma comparação do direito brasileiro com outros ordenamentos, $1^{\text {a }}$ edição, Curitiba, Juruá, 2008.

Poli, Roberto, Sulla sanabilità della inosservanza di forme prescritte a pena di preclusione e decadenza, Rivista di Diritto Processuale, 51:1996.

Pontes de Miranda, Francisco Cavalcanti, Comentários ao Código de Processo Civil, tomo II, Rio de Janeiro, Forense, 1974.

Comentários ao Código de Processo Civil, tomo VII, $3^{\text {a }}$ edição, revista e aumentada, Rio de Janeiro, Forense, 2002.

Porto, SÉrgio Gilberto, A crise de eficiência do processo - A necessária adequação processual à natureza do direito posto em causa, como pressuposto da efetividade, in Fux, luiz, Nery Jr., Nelson, Wambier, Teresa Arruda Alvim (coords.), Processo e Constituição - estudos em homenagem ao professor José Carlos Barbosa Moreira, São Paulo, Revista dos Tribunais, 2006.

Proto PisAni, Andrea, Appunti sulla giustizia civile, $1^{\text {a }}$ edição, Bari, Cacucci, 1982. , Lezioni di diritto processuale civile, $3^{\mathrm{a}}$ edição, Nápoles, Jovene, 1999. 
Provinciali, Renzo, Trattato del Processo Civile direto da Francesco Carnelutti-Delle impugnazione in generale, Nápoles, Morano, 1962.

PuOli, José CARLOS BAPTISTA, Breves considerações sobre o recurso de agravo em vista das inovações trazidas pela Lei 11.287/2005, in FuX, LuIZ, NERY JR., NeLSON, Wambier, Teresa Arruda Alvim (coords.), Processo e Constituição - estudos em homenagem ao professor José Carlos Barbosa Moreira, São Paulo, Revista dos Tribunais, 2006.

Redenti, EnRICo, Diritto Processuale Civile, v. 3, Milano, Giuffrè, 1957.

Reichardt, H. Canabarro, A reforma do Processo Civil - oralidade e concentração contribuição ao $1^{o}$ congresso nacional de Direito Judiciário, Rio de Janeiro, Officinas Graphicas d'A Noite, 1936.

Ribeiro, Leonardo Ferres da Silva, Prestação jurisdicional efetiva: uma garantia constitucional, in FuX, LUIZ, Nery JR., Nelson, WAMBIER, Teresa Arruda AlviM (coords.), Processo e Constituição - estudos em homenagem ao professor José Carlos Barbosa Moreira, São Paulo, Revista dos Tribunais, 2006.

RICCI, EDOARDO F., Doppio grado di diurisdizione (principio del), verbete in Enciclopedia Giuridica, v. 12, Roma, Istituto della Enciclopedia Italiana, Treccani, 1989.

Rosenberg, LeO, Tratado de derecho procesal civil, tomo II, v. 28, coleção Ciencia del Proceso, $1^{\mathrm{a}}$ edição, Buenos Aires, Ediciones Jurídicas Europa-América, 1955.

SAAD, EduARdo GABriel, CLT Comentada, 34 ${ }^{\mathrm{a}}$ edição, revista e ampliada por José Eduardo Saad e Ana Maria Saad Castello Branco, São Paulo, LTr, 2004. , Direito processual do trabalho, $2^{\mathrm{a}}$ edição, São Paulo, LTr, 1998.

SadeK, Maria Tereza, Juizados Especiais: um novo paradigma in SAlles, Carlos AlBerto DE (coord.), As grandes transformações do Processo Civil Brasileiro Homenagem ao Professor Kazuo Watanabe, $1^{\text {a }}$ edição, São Paulo, Quartier Latin, 2009.

Salles, Carlos Alberto de, Processo civil de interesse público in Salles, Carlos Alberto (org.), Processo civil e interesse público - o processo como instrumento de 
defesa social, São Paulo, Associação Paulista do Ministério Público e Revista dos Tribunais, 2003

SAnSeVerino, Milton, Fungibilidade dos recursos, Justitia, São Paulo, 124:1985.

Santos, Nelton Agnaldo Moraes dos, in Marcato, Antonio Carlos (coord.), Código de Processo Civil interpretado, $3^{\mathrm{a}}$ edição, São Paulo, Atlas, 2007.

Scarpinella Bueno, Cassio, Efeitos dos recursos in Nery Jr., Nelson, Wambier, Teresa Arruda Alvim (coords.), Aspectos Polêmicos e atuais dos recursos cíveis e assuntos afins, v. 10, 1ª edição, São Paulo, Revista dos Tribunais, 2006.

Sica, Heitor Vitor MendonçA, Algumas implicações do novo conceito de sentença no Processo civil, de acordo com a Lei $n^{\circ} 11.232 / 2005$ in CARMONA, CARLOS ALBERTO (coord.), Reflexões sobre a Reforma do Código de Processo Civil - Estudos em homenagem a Ada Pellegrini Grinover, Cândido R. Dinamarco e Kazuo Watanabe, $1^{\mathrm{a}}$ edição, São Paulo, Atlas, 2007.

, O agravo e o "mito de Prometeu”: considerações sobre a Lei 11.187/2005 in NERY Jr., Nelson, Wambier, Teresa Arruda Alvim (coords.), Aspectos polêmicos e atuais dos recursos cíveis e assuntos afins, v. 9, $1^{\text {a }}$ edição, São Paulo, Revista dos Tribunais, 2006.

, Preclusão Processual Civil, 2a edição, São Paulo, Atlas, 2008.

, Recorribilidade das interlocutórias e reformas processuais: novos horizontes do agravo retido in Nery JR., Nelson, Wambier, Teresa Arruda Alvim (coords.), Aspectos polêmicos e atuais dos recursos cíveis e de outros meios de impugnação às decisões judiciais, v. 8, São Paulo, Revista dos Tribunais, 2005.

SoARes, Nildomar Da Silveira, Juizado especial cível - a justiça da era moderna, $3^{\mathrm{a}}$ edição, São Paulo, LTr, 1996.

Souto Maior, Jorge Luiz, Procedimento oral: um pressuposto da efetividade do processo do trabalho, tese (doutorado em Direito do Trabalho), Faculdade de Direito - Universidade de São Paulo, São Paulo, 1997. 
TAruffo, Michele (em coautoria), Ferri, Corrado, Comoglio, Luigi PaOlo, Lezioni sul processo civile, $1^{\text {a }}$ edição, Bologna, Il Mulino, 1995.

TARZIA, GiUsepPe, Profili della sentenza civile impugnabile - l'individuazione della sentenza, Milão, Giuffrè, 1967.

TEISHEner, José MARIA Rosa, Em tempo de reformas - o reexame de decisões judiciais, in FABRicio, AdROALdo FURTAdo (coord.), Meios de impugnação ao julgado civil estudos em homenagem a José Carlos Barbosa Moreira, Rio de Janeiro, Forense, 2007.

Teixeira, SÁlvio de Figueiredo, A efetividade do processo e a reforma processual in CRuz E TuCCI, José Rogério (coord.), Processo civil: evolução - 20 anos de vigência, $1^{\mathrm{a}}$ edição, São Paulo, Saraiva, 1995.

, O processo civil na nova Constituição, Justitia, São Paulo, 50:1988.

TeiXeira Filho, Manoel A., Sistema dos Recursos Trabalhistas, $9^{\mathrm{a}}$ edição, atualizada de acordo com a Lei n. 9.139/95, São Paulo, LTr, 1997.

TheOdoro JR., Humberto, A preclusão no processo civil, obtido em www.rtonline.com.br, originalmente publicado em Revista dos Tribunais, 794: 2001.

, Celeridade e efetividade da prestação jurisdicional. Insuficiência da reforma das leis processuais, obtido em www.rtonline.com.br, originalmente publicado em Revista de Processo, 125:2005.

, Curso de Direito Processual Civil, v. 1, 50 a edição comemorativa, Rio de Janeiro, Forense, 2009.

, O problema da recorribilidade das interlocutórias no processo civil brasileiro, disponível em www.abdpc.org.br, acesso em 21.4.2011.

, O processo civil brasileiro no limiar do novo século, $1^{\mathrm{a}}$ edição, Rio de Janeiro, Forense, 1999.

, Processo justo e contraditório dinâmico, disponível em http://www.rechtd.unisinos.br/index.php? $\mathrm{e}=3 \& \mathrm{~s}=9 \& \mathrm{a}=91$, acesso em 6.7.2011. 
Tourinho Neto, Fernando da Costa (em coautoria), Figueira Júnior, Joel Dias, Juizados Especiais Federais Cíveis e Criminais (Comentários à Lei 10.259, de 10.07.2001), $2^{\mathrm{a}}$ edição revista, atualizada e ampliada, São Paulo, Revista dos Tribunais, 2007.

TUCCI, RogÉRIO LAURIA, Juiz natural, competência recursal, preclusão pro iudicato, violação de literal disposição de lei e ação rescisória, Revista dos Tribunais, 838:2005.

, Juizado especial de pequenas causas (anotações à Lei n. 7.244, de 7-11-1984, $1^{\mathrm{a}}$ edição, São Paulo, Saraiva, 1985.

VAsconcelos, ANTONio Vital RAmos DE, $O$ pedido de reconsideração e a preclusividade das decisões judiciais, obtido em www.rtonline.com.br, originalmente publicado em Revista dos Tribunais, 616:1987.

Vigliar, José Marcelo Menezes in Marcato, Antonio Carlos (coord.), Código de Processo Civil Interpretado, $3^{\mathrm{a}}$ edição revista e atualizada, São Paulo, Atlas, 2008.

Vincent, JeAn (em coautoria), Guinchard, Serge, Procédure civile, 20a edição, Paris, Dalloz, 1981.

WAmbier, Teresa Arruda Alvim, Mandado de segurança contra ato judicial, obtido em www.rtonline.com.br, originalmente publicado em Revista de Processo, 107:2002.

, Os agravos no CPC brasileiro, v. 2, coleção Recursos no Processo Civil, $4^{\mathrm{a}}$ edição revista, ampliada e atualizada, São Paulo, Revista dos Tribunais, 2005.

, O conceito de sentença no CPC reformado, in FABRícIO, AdROALDO FURTADO, Meios de impugnação ao julgado civil - estudos em homenagem a José Carlos Barbosa Moreira, Rio de Janeiro, Forense, 2007.

, O novo recurso de agravo, na perspectiva do amplo aceso à justiça, garantido pela Constituição Federal, in Fux, Luiz, Nery Jr., Nelson, Wambier, TeresA Arruda Alvim (coords.), Processo e Constituição - estudos em homenagem ao professor José Carlos Barbosa Moreira, São Paulo, Revista dos Tribunais, 2006. 
(em coautoria), Garcia Medina, José Miguel, Recursos e Ações Autônomas de Impugnação, v. 2, coleção Processo Civil Moderno, São Paulo, Revista dos Tribunais, 2008.

Watanabe, KaZuo, Cognição no processo civil, $4^{\mathrm{a}}$ edição, revista e atualizada, São Paulo, Saraiva, 2012.

,Filosofia e características básicas do Juizado Especial de Pequenas Causas in Watanabe, Kazuo (coord.), Juizado Especial de Pequenas Causas (Lei 7.244, de 7 de novembro de 1984), São Paulo, Revista dos Tribunais, 1985.

, Tutela antecipatória e tutela específica das obrigações de fazer e não fazerarts. 273 e 461, CPC, obtido em www.rtoline.com.br, originalmente publicado em Revista de Direito do Consumidor, 19:1996.

YARSHELl, FlÁVIO LUIZ, Alterações nas regras que disciplinam o agravo de instrumento: primeiras impressões, Revista do Advogado, 84:2005.

, Tutela Jurisdicional, 2a edição, revista e atualizada, São Paulo, DPJ, 2006.

ZARIF, ClÁudio Cintra, Da necessidade de repensar o processo para que ele seja realmente efetivo, in FuX, LUIZ, NERY JR., NELSON, WAMBIER, TERESA ARRUDA Alvim (coords.), Processo e Constituição - estudos em homenagem ao professor José Carlos Barbosa Moreira, São Paulo, Revista dos Tribunais, 2006. 


\section{ÍNDICE DE FONTES}

Anteprojeto de novo Código de Processo Civil (Brasil - 2010)

Código de Processo Civil (Brasil - 1939) - Decreto-Lei n 1.608/1939 (revogado)

Código de Processo Civil (Brasil - 1973) - Lei no 5.859/1973

Codice de Procedura Civile (Itália - 1940) - Decreto Real nº1443/1940

Conselho Nacional de Justiça - relatórios "Justiça em números" - disponíveis em www.cnj.jus.br

Consolidação das Leis do Trabalho - Decreto-lei no 5.452/1943

Constituição da República Federativa do Brasil de 1988

Convenção Americana sobre Direitos Humanos (Costa Rica - 1969; Decreto nº 678/1992)

Declaração Universal dos Direitos do Homem (ONU, Nova Iorque, 1948)

Enunciados do Fórum Nacional dos Juizados Especiais - disponível em http://www.fonaje.org.br/2012/?secao=exibe_secao\&id_secao $=6$

Enunciados dos Juizados Especiais Cíveis e Turmas Recursais do Estado do Rio de Janeiro - disponível em http://www.tjrj.jus.br/web/guest/institucional/juizespeciais/documentos/enunciados

Enunciados dos Juizados Especiais Cíveis e Colégios Recursais do Estado de São Paulo disponível em https://esaj.tjsp.jus.br/genPtl/abrirDetalhesLegislacao.do?cdLegislacaoEdit=52803\&flBtV oltar $=\mathrm{N}$

Exposição de motivos do Código de Processo Civil (Lei nº 5.869/1973)

Jurisprudência do Superior Tribunal de Justiça - disponível em www.stj.jus.br

Lei Federal no 7.244/1984 (revogada)

Lei Federal no 9.099/1995

Lei Federal $n^{\circ} 10.259 / 2001$

Projeto de Lei do Senado $n^{\circ} 166 / 2010$ (autor: José Sarney)

Projeto de Lei ${ }^{\circ}$ 8.046/2010

Relatório da Comissão Especial destinada a proferir parecer ao Projeto de Lei ${ }^{0} 6.025$, de 2005, ao Projeto de Lei ${ }^{\circ}$ 8.046, de 2010, ambos do Senado Federal, e outros, que tratam do "Código de Processo Civil" (revogam a Lei no 5.869, de 1973) (relator-geral: Sérgio Barradas Carneiro) 